Ottmar Ette/Friederike Pannewick (eds.) ArabAmericas. Literary Entanglements of the American Hemisphere and the Arab World

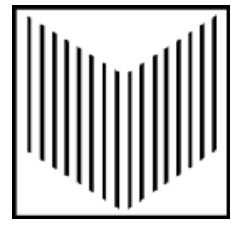


B I B L I O T H E C A IB E R O - A M E R I C A N A

Veröffentlichungen des Ibero-Amerikanischen Instituts Preußischer Kulturbesitz

Band 110 
B I B L I O T H E C A I B E R O - A M E R I C A N A

\author{
Ottmar Ette / Friederike Pannewick \\ (eds.)
}

\title{
ArabAmericas \\ Literary Entanglements of the American Hemisphere and the Arab World
}

Iberoamericana $\cdot$ Vervuert

2006 
Bibliographic information published by die Deutsche Bibliothek

Die Deutsche Bibliothek lists this publication in the Deutsche

Nationalbibliografie; detailed bibliographic Data are available on the Internet at http://dnb.ddb.de.

All rights reserved

(C) Vervuert Verlag, 2006

Wielandstr. 40 D-60318 Frankfurt am Main

(C) Iberoamericana, 2006

Amor de Dios, 1 E-28014 Madrid

info@iberoamericanalibros.com

www.ibero-americana.net

ISSN 0067-8015

ISBN 3-86527-289-4 (Vervuert)

ISBN 84-8489-268-9 (Iberoamericana)

Cover Design: Michael Ackermann

Illustration: Mariano Procopio

Composition: Anneliese Seibt, Ibero-Amerikanisches Institut PK

Printed in Spain 


\section{CONTENTS}

\section{The Editors}

The American Hemisphere and the Arab World.

Introduction

Ottmar Ette

Literatures without a Fixed Abode. Figures of

Vectorial Imagination beyond the Dichotomies

of National and World Literature

Susana Romano Sued

The Castilian Language, a Mosaic of Languages:

An Exercise of the Memory as a Genealogy and

Archeology of Culture

Anna Akasoy

Exile and Alienation in the Poetry of the Early

Southern Mahjar

Elias Khoury

Literature and Emigration

Luis Fayad

Lebanese Migration to the Americas

Lisa Suhair Majaj

New Directions: Arab American Writing Today

Nathalie Handal

Our Roots in the Mezze: The Politics of Food and

Arab-American Women Poets

Verónica Murguía

My Unknown Forefathers 
Dieter Ingenschay

Between the Boom and the Arabesque. 'Hemispheric

Writing' in Juan Goytisolo's Paisajes después de la

batalla and Milton Hatoum's Relato de um certo Oriente

Alberto Mussa

Who is Facing the Mirror?

Roland Spiller

Dangerous Liaisons: Transatlantic Multilingualism

in Latin American and Maghreb Literature. With

Examples from Elias Canetti, Jorge Luis Borges,

Rubén Darío, Assia Djebar

Ottmar Ette

Chronicle of a Clash Foretold?

ArabAmerican Dimensions and Transareal Relations

in Gabriel García Márquez and Elias Khoury

Alberto Ruy-Sánchez

The Nine Gifts that Morocco Gave Me

Andreas Pflitsch

To Fit or Not to Fit.

Rabih Alameddine's Novels Koolaids and I, the Divine 275

The Authors 285 


\section{The American Hemisphere and the Arab World. Introduction}

Yo lo vi en su memoria. Había cumplido 21 años la última semana de enero, y era esbelto y pálido, y tenía los párpados árabes y los cabellos rizados de su padre. Era el hijo único de un matrimonio de conveniencia que no tuvo un solo instante de felicidad, pero él parecía feliz con su padre hasta que éste murió de repente, tres años antes, y siguió pareciéndolo con la madre solitaria hasta el lunes de su muerte. De ella heredó el instinto. De su padre aprendió desde muy niño el dominio de las armas de fuego, el amor por los caballos y la maestranza de las aves de presas altas, pero de él aprendió también las buenas artes del valor y la prudencia. Hablaban en árabe entre ellos, pero no delante de Plácida Linero para que no se sintiera excluida (García Márquez 1981: 15-16). ${ }^{1}$

The young man described here is Santiago Nasar, the murder victim in Crónica de una muerte anunciada (1981) by the Colombian author Gabriel García Márquez and possibly the best-known Latin-American Arab in world literature.

Between 1860 and 1914, quite a few Levantine immigrants arrived in the U.S.A. and Canada, but also in Latin America, Australia and, to a lesser degree, West Africa. ${ }^{2}$ In famous novels by authors like Gabriel García Márquez or Milton Hatoum, we might find typical figures of Levantine traders - "Turcos", as they are usually called, even if only few of them were Turkish, but rather Middle Eastern inhabitants of the Ottoman Empire. ${ }^{3}$ Arab immigration to Latin America

1 "I saw him in her memory. He had turned twenty-one the last week in January, and he was slim and pale and had his father's Arab eyelids and curly hair. From his father he learned at a very early age the manipulation of firearms, his love for horses, and the mastery of high-flying birds of prey, but from him he also learned the good arts of valor and prudence. They spoke Arabic between themselves, but not in front of Plácida Linero, so that she wouldn't feel excluded.”

2 Detailed references for the early Southern Mahjar (Exile) can be found in Anna Akasoy, "Exile and Alienation in the Poetry of the Early Southern Mahjar" in this volume.

3 See in this volume Dieter Ingenschay's article on Milton Hatoum and Juan Goytisolo "Between the Boom and the Arabesque. 'Hemispheric Writing' in Juan Goytisolo’s Paisajes después de la batalla and Milton Hatoum’s Relato de um certo Oriente". 
and the U.S.A. began at roughly the same time, but while immigration to the U.S.A. has increased tremendously over the last 150 years, in South America it began to decline after 1960.

After a long process of emancipation and recognition, authors of Arab descent are now entering the North, Middle and South American mainstream. ${ }^{4}$ Although earlier generations of writers drew on the traditional Arab canon of aesthetics (and contexts, often in the Arabic language), third- or fourth-generation immigrant writers have forged new paths between Arab and American literary traditions. After the unexpected and overwhelming international success of the Lebanese poet Gibran Khalil Gibran, who was one of the pioneers of ArabAmerican literature written in English in the early decades of the twentieth century, four decades of a rather shadowy existence of Arab American literature in different parts of the Americas were to follow.

It was not before the 1980s that Arab immigrants and their children and grandchildren started to be perceived in the American public sphere as a more or less homogeneous group having a common cultural background and profile. In the mid-1980s, D. H. Melhem organized the first ArabAmerican Poetry Reading at the Modern Language Association (1984) in the U.S. This event, together with the publication of Gregory Orfalea's and Sharif Elmusa's anthology in 1988 (Orfalea/Elmusa 1988), helped in connecting Arabic narrative traditions with the (US-)American literary canon and thus leveraged a new Arab American self-esteem. Internationally acknowledged authors like Samuel J. Hazo, Etel Adnan, Milton Hatoum or Naomi Shihab Nye play an important part as role models in promoting integration in the ArabAmerican communities. Since the 1990s, various literary anthologies have been published, ${ }^{5}$ and journals like al-Jadid: A Review and Record of Arab Culture and Art (1995) and Mizna. Prose, Poetry and Art Exploring Arab America (1998) act as important mediators for ArabAmerican voices.

4 For a more detailed survey of recent developments in the U.S., cf. Lisa Suhair Majaj's article in this volume: “New Directions: ArabAmerican Writing Today”; a survey of Libanese migration to the Americas is given in this volume in Luis Fayad, "Lebanese Migration to the Americas".

5 Cf. publications like Kadi (1994), Suleiman (1999), Hall/Hall (1999), Kaldas/ Mattawa (2004). 
By the end of the 1990s an anthology of ArabAmerican creative and critical writing, co-edited by the Syrian Munir Akash and the Libyan Khaled Mattawa, both of whom moved to the U.S.A. several decades ago, was published by Syracuse University Press (Akash/Mattawa 1999). In this anthology, different genres, like memoirs, diaries and journals, as well as poetry, drama, excerpts from novels and short fiction are gathered. The authors are Arabs having moved to the U.S. as immigrants as well as Americans of Arab origin; but the highly interesting concept of this anthology includes also American authors of non-Arab origin, like the US poet Daniel Moore, author of Ramadan Sonnets, or Penny Johnson, who has been living in Palestine and is engaged in Women's Studies and Human Rights issues - American authors who have come to be strongly involved in Arab culture and literature in their writing. ${ }^{6}$

The anthology Post Gibran has been judged by one of the leading contemporary Arab poets, the Palestinian Mahmūd Darwīsh, as a lesson to 'exiles' in the broadest sense of the term, "to find creative grassroots in their country of exile”. The literary critic and editor of the literary journal Alif, Ferial Ghazoul (American University of Cairo), enthusiastically praised the innovative potential of these 'creative grassroots' in the new ArabAmerican space of literary activity. Ghazoul points in her review of this publication to the innovative potential of this emerging, transnational, syncretic and self-confident ArabAmerican literature:

What is refreshing and striking in these essays is their acknowledgement of the past and the present and their orientation towards the future, determined to have a place of their own in the new world. Theirs is not a sense of nostalgia for the past and for the homeland, as is often witnessed in the writing of the Mahjar ${ }^{7}$ poet, nor is it the total rejection of the new culture while cocooning oneself in traditional values, as Arabs with a ghetto mentality have done. In opposition these new voices call for forging a conscience of the Arab stream in American culture, not only to preserve a static identity, but also to call on one's heritage to contribute to, and upgrade, the dynamic combination of cultural strands in the adopted country (Ghazoul 2000).

6 Nathalie Handal treats these questions in her article "Our Roots in the Mezze: The Politics of Food and Arab-American Women Poets" in this volume.

7 North- and South-American exile, note of the editors. 
In an approach coming in some respects quite close to Post Gibran's concept, the anthology "ArabAmericas - the American Hemisphere and the Arab World" focuses on North and South American literatures that have no fixed abode. Looking beyond European categories of fixed identities and transcending the concept of nations as patched-together collectives, this anthology will seek alternatives amidst transregionally constituted cultures. The authors are interested in transitions, overlaps and movement - elements of cultural mobility that, in our view, are highly relevant for the emerging literatures of the world. Such processes can best be studied in biographies that are not tied to one place and in literary works that have not emerged from a single (linguistic) community.

In this collective volume, we want to reverse the traditional perspective of literary scholarship: for research purposes the various contributors will view the "norm" - i.e. classifiable, uniform and standardized literary works - as the exception. The authors intend to take seriously the often-cited examples of "cultural hybridity", that is, to attempt to grasp them on the basis of the conditions that lead to their emergence, instead of relying on those examples of the prevailing discourse.

The Arabic vernacular spoken by immigrants in the late 19th and early 20th century, the Creole languages in the Caribbean, and the Portuguese spoken by slaves in Brazil - all have demonstrated their relevance in everyday and theoretical application beyond the boundaries of standardized national languages in the context of globally entangled histories that result from different periods of accelerated globalization.

Concretely, we will make "Arab-American" literatures the subject of study in all their diversity. This volume's goal is not to illustrate and analyze (i.e. dissect) the elements of these literatures (Arabic, Anglo, Hispano, Luso and Francophone), but rather to concentrate on the (added) value of what is often looked down upon as a hodgepodge. Since these literatures have been undergoing significant and increasing changes, the methods, readings and interpretative approaches developed over the years cannot be taken as fixed constants and applied without further questioning. Categories such as "national literature" or "world literature" are only effective to a limited degree and in specific 
contexts. Our goal is to search for adequate intellectual categories, the "in between" and the crossovers of national and world literature. ${ }^{8}$

In an interview, the Hungarian author Imre Kertesz pointed at the questionable value of the conventional notions of 'home', 'native country' or 'national identity':

I am a stranger in this world. But this is not a problem at all. As I won't have the right but to claim my strangeness down on earth and in heaven, this hopefully is my right. At home? Native country? - Once upon a time we maybe could speak about all of this in completely different terms, or we did not speak about it at all. Maybe one day somebody will grasp that these are nothing but abstract terms and that the only thing we really need in our life is just a place fit to live in. I have been feeling this for a long time.

The notion of "being or feeling like a stranger" as the essential category of an artist's or a writer's life, was one of the key notions that have been discussed in the first colloquium on "ArabAmericas" during a conference held by the Working Group "Ways of Knowledge: Transregional Studies" at the Institute for Advanced Study at Berlin (Wissenschaftskolleg zu Berlin; conveners: Ottmar Ette, Friederike Pannewick, Andreas Pflitsch) in December 2004.

During this colloquium, as well as during a series of lectures held under the title "ArabAmericas - Transatlantic Constructions" at the University of Potsdam, the Humboldt University Berlin, the Latin American Institute at Freie Universität Berlin and the Ibero-American Institute Prussian Heritage Foundation during the spring term of $2005,{ }^{9}$ we debated questions such as: Is it really special for writers with a so-called "double or multiple identity" to feel at home at more than one place in the world, or not to feel at home anywhere at all? What does it mean to feel at home? Is "home" a category of place, or rather an intellectual category? Do we have to deal with the category of "transcendental homelessness" instead? During the vivid debates at

8 This volume's article "Literatures without a Fixed Abode. Figures of Vectorial Imagination beyond the Dichotomies of National and World Literature” by Ottmar Ette deals with this subject. See also in this volume the article by Roland Spiller "Dangerous liaisons: Transatlantic multilingualism in Latin American and Maghreb literature”. For more details, see also Ette (2005).

9 The first two lecture series were dedicated to "The power of Borders/the Borders of Power" and "Hemispheric Constructions of the Americas". See Braig/Ette/Ingenschay/Maihold (2005; 2006); see also the two dossiers in Iberoamericana (Braig/Ette 2004; 2005). 
this first meeting and the following lectures organized by "Forschungsverbund Lateinamerika Berlin-Brandenburg”, the participants were discussing central issues of literatures with no fixed abode in the context of the current period of accelerated globalization, debates that have deeply marked their contributions to the present book.

This first colloquium, which (together with the lecture series) was followed up in June 2005 under the title "ArabAmericas - Transatlantic" (conveners: Friederike Pannewick, Ottmar Ette), was held in the context of a research project called "Cultural Mobility in Near Eastern Literatures". This project, initiated in 2001, has since then been part of the Institute for Advanced Study's Working Group “Modernity and Islam", and it also contributes some of its activities to the recently founded Research Network "Ways of Knowledge" (Wege des Wissens), based at the Institute for Advanced Study as well. ${ }^{10}$

The main focus in all these activities at the Institute for Advanced Study is on the diverse processes of transfer, exchange and interaction between the literatures of the Near East and other world literatures. ${ }^{11}$ What we dealt with in these meetings was to try to cope with movement, as movement is indispensable and crucial for mobility. Mobility is a constituent component of culture. Cultures are inescapably and constantly in motion through time and space. This fact opens cultures up to the unforeseeable, which is the principal attribute of movement.

In the project "Cultural Mobility in Near Eastern Literatures", including researchers coming from different national philologies inside and outside Europe, we observe and discuss phenomena of mobility in Arabian, Persian and Turkish literatures. In the second step, we always ask: what about these phenomena in other literatures of the world? With good reason we do not confine our research to the traditional perspective of East-West or South-North relations. We care much about South-South relations - for instance African, or in the current case Latin American and Arab literary entanglements -, and

10 Cf. <http://www.wiko-berlin.de/projects/>.

11 Some of the main aims and concepts of the "Cultural Mobility" work group will be transferred to the transdisciplinary international research network called "Travelling Traditions - Comparative Perspectives on Middle Eastern Literatures”, that is located within the working group "Europe in the Middle East - the Middle East in Europe" at the Institute for Advanced Study at Berlin (2006-2011; cf. $<$ http://www.wiko-berlin.de/projects/>). 
we try to avoid unilateral perspectives as much as possible. The work in this project is demanding in a double sense: it is daring and innovative, but sometimes it is also quite tiring and seems to try the impossible. To study the restless movements in literatures of the world means having to cope with a constant interpretational suspense.

In this context, we were happy that we could convince four very interesting authors to participate in our first meeting in December 2005: Two of them, Verónica Murguía and Elias Khoury, live more or less in their native country (Elias Khoury is Visiting Professor of Comparative Literature at New York University in spring terms and edits the cultural supplement of Lebanon's daily newspaper al-Nahār during the rest of the year in Beirut). Both are deeply inspired in their literary work by other world literatures: the Mexican writer Verónica Murguía uses story-telling techniques of The Arabian Nights and reflects upon the biographies of famous Arab poets in some of her short stories, ${ }^{12}$ whereas Elias Khoury, one of the leading novelists and journalists of Lebanon whose novels have been translated into nearly all European languages, loves to play transareal games with Latin American literature. In one of his novels, Khoury traces back the biography of García Márquez' Lebanese protagonists to their life in Lebanon before their immigration to Latin America by integrating these Arab American figures into his own novels which deal with recent Lebanese history. ${ }^{13}$

The other two artists are well-known authors in their societies, in Brazil and Latin America, as well as in the United States. Alberto Mussa was born in a family of Lebanese and Palestinian origin in Rio de Janeiro and lives in Brazil, where he studied Tupi, the language of the Brazilian natives, some African languages and Arabic. Alberto Mussa grew up in Brasilia without learning any Arabic; as a student he felt the urgent need to learn more about the culture of his forefathers. This is why Alberto Mussa studied Arabic and then started to translate classical Arabic poetry into Portuguese. And it was during this work of cultural mobility that this ArabAmerican writer felt for

12 See her article in this volume, "My Unknown Forefathers".

13 For cross-references between Gabriel García Márquez and the Lebanese author Elias Khoury, cf. Ottmar Ette, "Chronicle of a Clash Foretold? ArabAmerican Dimensions and Transareal Relations in Gabriel García Márquez and Elias Khoury” in this volume. See also Elias Khoury's essay "Literature and Emigration”. 
the first time in his life "at home": the moment he translated this poetry written some hundred years ago by his Arabic ancestors into his mother tongue Portuguese. So, the act of trans-lation, of trans-action, became a kind of identity building. ${ }^{14}$

Rabih Alameddine, an internationally acclaimed painter and novel writer, grew up in Kuwait and spent the summers in Lebanon on a regular basis. As a teenager, when the Civil War started in Lebanon, he was forced to leave the country and went to school in England. Then, as a sixteen year old boy, he moved finally to the U.S. Until now he has published three novels in English. In his first novel Koolaids. The Art of War the narrator utters a wonderful phrase that says much about the existential state of being that applies to quite a few of the authors represented and dealt with in the anthology Arab Americas: "In America, I fit, but I do not belong. In Lebanon, I belong, but I do not fit."15

At the second workshop held in Berlin in June 2005, five creative writers, literary critics and researchers from Mexico, the U.S.A., Argentina, Colombia and Germany followed the invitation of the Institute for Advanced Study at Berlin. Among them was Alberto Ruy Sánchez from Mexico. While living in Paris for almost a decade, he came under the influence of Roland Barthes, Gilles Deleuze and Jacques Rancière and began to work as a writer and editor. In the mid1980s, Ruy Sánchez worked as an editorial journalist for the famous magazine Vuelta, founded by Octavio Paz. Since 1988 he has been the Chief Editor and Founding Publisher of Latin America's leading art magazine, Artes de México. His books have won numerous awards and have been translated into various languages, including French and Arabic. Ruy Sánchez links elements of magic realism with Arabic mysticism, invoking a sensual and spiritual mood in everyday Islamic life. In his prose, Ruy Sánchez aims to reconstruct the Arabic roots of Hispanic and Hispano-American culture. ${ }^{16}$

An American-Palestinian perspective entered this workshop's debates through Lisa Suhair Majaj and Nathalie Handal. Lisa Suhair

14 His text "Who Is Facing the Mirror?" in this volume tells this personal story.

15 Cf. Andreas Pflitsch, "To Fit or not to Fit. Rabih Alameddine's Novels Koolaids and $I$, the Divine" in this volume.

16 His essay in this volume, "The Nine Gifts that Morocco Gave Me", is an account of this relation. 
Majaj was born in the U.S.A. to a Palestinian father and a U.S.-American mother. She grew up in Jordan and studied at the University of Beirut. After the evacuation out of Lebanon in the summer of 1982 during the Israeli invasion, she subsequently moved to the United States to continue her education. She has been living in Cyprus since 2001.

For contemporary Palestinian authors in the West, the expulsion from their homeland resulted in physical dislocation as well as linguistic, generational and cultural differences with writers in the Middle East. ArabAmerican authors are addressing the need to translate their configurations of identity into language, and this language is usually English. Lisa Suhair Majaj extensively studied the ArabAmerican literature in her $\mathrm{PhD}$ thesis at the University of Michigan; her poetry, essays and book reviews have been published in a variety of international journals and anthologies. According to Lisa Suhair Majaj, the new generation is trying to create an ArabAmerican literary space and genre that places their Arab heritage in an American context.

The question of having different options for national and cultural belonging is also a crucial issue in the scientific and literary writings of Nathalie Handal. Having Palestinian parents and being raised in Paris, Boston, the West Indies and Latin America can make ethnicity a complex question, explains poet Nathalie Handal: "I feel I'm a Bostonian Parisian" she said in a broadcast interview, noting that she had most recently lived in London and now calls New York City her home. Nathalie Handal reflected in this radio talk on the different layers of cultural perception; she explained that Arabs often consider her an American since she writes in English and does not speak fluent Arabic. On the other hand, Americans, when they learn about her background, consider her an Arab. But in Handal's perception, an Arab is anyone of Arab descent who chooses that label. Nathalie Handal also lamented the confusion many Americans from the U.S. display about the rest of the world. When she tells people that her family comes from Bethlehem, she said they may respond, "Bethlehem, Pennsylvania?' I'd say, 'Palestine', and they'd say, 'Oh, Pakistan'. It's amazing”.

Poet, playwright, writer, editor, critic and literary activist, Nathalie Handal is the editor of The Poetry of Arab Women: A Contemporary 
Anthology (Handal 2001), an Academy of American Poets bestseller and winner of the Pen Oakland/Josephine Miles Award. Handal is presently editing two anthologies that might be interesting for research in our field, namely Dominican Literature and ArabAmerican Literature, and co-editing along with Tina Chang and Ravi Shankar, Risen from East: An Anthology of South Asian, East Asian and Middle Eastern Poets.

Originally from Bogotá, Colombia, the writer Luis Fayad joined the second ArabAmerican meeting in Berlin in June 2005. Within the group of Colombian writers who began to publish their books in the middle of the publishing boom of Gabriel García Márquez, Luis Fayad occupies a central place. Luis Fayad was born in Bogotá, but he spent most of his life outside Colombia, living in Paris, Barcelona, and finally Berlin. The grandparents of this author emigrated from Lebanon to Colombia, but while his parents still learnt to speak Arabic, he did not. He had to leave Colombia and come to Berlin to start learning Arabic in Germany ...

Some fascinating insights into the world of Argentinean-Syrian cultural entanglements have been contributed by Susana Romano Sued from Córdoba, Argentina. ${ }^{17}$ Born as a daughter of a Syrian mother and an Argentinean father, Susana Romano Sued, due to the dictatorship in Argentina, settled in Germany, where she got her PhD with a thesis on the poetry of Gottfried Benn and the translations of his work into Spanish. Back in Argentina, she dealt abundantly with the inheritance and traditional customs of the Argentinean Middle East in her outstanding poetic and literary texts.

This volume is - as already mentioned above - based on contributions made during two workshops at the Institute for Advanced Studies at Berlin and a lecture series at various research institutions and universities in Berlin-Brandenburg. These contributions were made by researchers in Romance and Middle Eastern Studies, by journalists and creative writers. This volume intends to keep the lively and highly stimulating atmosphere during these cross-cultural and multilingual meetings. This is why academic studies elaborated in ArabAmericas will be found side by side with more personal statements based on

17 See her article "The Castilian Language, a Mosaic of Languages: An Exercise of the Memory as a Genealogy and Archaeology of Culture" in this volume. 
individual memories and experience. This consciously chosen open structure has also been considered most appropriate regarding the system of transcribing Arab proper names and technical terms in Latin script. As many proper names of Arab descent started to lead an independent existence in between different national communities throughout the decades, it would have been rather artificial and far off every day's transcultural practice to re-transcribe them back to their linguistic roots. Therefore, we did not try to standardize the transcription system in the various articles of this volume. Consistency is to be found only within each single article, not in the anthology as a whole.

We would like to express our gratitude to the Institute for Advanced Study at Berlin, the Ibero-American Institute Prussian Heritage Foundation, the German Academic Exchange Service (DAAD), the Forschungsverbund Lateinamerika Berlin-Brandenburg and the University of Potsdam for funds and travel grants. Our special thanks go to Felicitas Hentschke and Christine Hofmann (Berlin) as well as to Gabriele Penquitt, Ulrike Zieger, Marcel Vejmelka and Mark Minnes (Potsdam) for invaluable help and good spirits.

The Editors

\section{Bibliography}

Akash, Munir/Mattawa, Khaled (1999) (eds.): Post Gibran: An Anthology of New Arab-American Writing. Syracuse/Jusoor: Syracuse University Press.

Braig, Marianne/Ette, Ottmar (2004) (eds.): “Dossier: Fronteras del poder, poder de las fronteras”. In: Iberoamericana IV, 16, pp. 69-146.

- (2005) (eds.): "Dossier: Construcciones hemisféricas”. In: Iberoamericana V, 20, pp. 83-158.

Braig, Marianne/Ette, Ottmar/Ingenschay, Dieter/Maihold, Günther (2005) (eds.): Macht der Grenzen/Grenzen der Macht. Lateinamerika im globalen Kontext. Frankfurt/Main: Vervuert.

Birle, Peter/Braig, Marianne/Ette, Ottmar/Ingenschay, Dieter (2006) (eds.): Hemisphärische Konstruktionen der Amerikas. Frankfurt/Main: Vervuert.

Ette, Ottmar (2005): ZwischenWeltenSchreiben. Literaturen ohne festen Wohnsitz. Berlin: Kulturverlag Kadmos.

García Márquez, Gabriel (1981): Crónica de una muerte anunciada. Barcelona: Editorial Bruguera.

Ghazoul, Ferial (2000): "Building bridges, joining streams". In: Al-Ahram Weekly Online 481 (11-17 May), <http://weekly.ahram.org.eg>. 
Hall, Bridget K./Hall, Loretta (1999) (eds.): Arab American Biography. Farmington Hills: Gale Research.

Handal, Nathalie (2001) (ed.): The Poetry of Arab Women: A Contemporary Anthology. New York: Interlink Publishing.

Kadi, Joanna (1994) (ed.): Food for our Grandmothers. Writings by Arab-American and Arab-Canadian Feminists. Boston: South End Press.

Kaldas, Pauline/Mattawa, Khaled (2004) (eds.): Dinarzad's Children: An Anthology of Contemporary Arab American Fiction. Fayetteville: University of Arkansas Press.

Orfalea, Gregory/Elmusa, Sharif (1988) (eds.): Grape Leaves: A Century of ArabAmerican Poetry. Salt Lake City: Interlink Publishing.

Suleiman, Michael (1999): Arabs in America: Building a New Future. Philadelphia: Temple University Press. 


\section{Ottmar Ette}

\section{Literatures without a Fixed Abode. Figures of Vectorial Imagination Beyond the Dichotomies of National and World Literature}

\section{World Literature and Mobile Specialization}

In his 1952 festschrift essay with the programmatic title "Philologie der Weltliteratur" ("Philology of World Literature"), Erich Auerbach - author of Mimesis: Dargestellte Wirklichkeit in der abendländischen Literatur (Mimesis: The Representation of Reality in Western Literature), composed between May 1942 and April 1945 in his Istanbul exile - sketched the outlines of a philology that in the wake of the Second World War would elucidate the "profound changes in the general condition of life", and afford "insight into their total significance" ${ }^{2}$ and suggest 'the practical consequences' to be drawn therefrom (Auerbach 1967: 302). Important for this German-Jewish emigrant - who starting in 1947 taught Romance languages and literature at different renowned universities in the United States - was a critical development of Goethe's concept of Weltliteratur (world literature), which, as Auerbach well knew, was in large part conceived by Germany's national poet as a foil to the dominant concept of national literature. ${ }^{3}$ Goethe's remark of 31 January 1827 was paradigmatic: "Nationalliteratur will jetzt nicht viel sagen, die Epoche der Weltliteratur ist an der Zeit, und jeder muß jetzt dazu wirken, diese Epoche zu beschleunigen” (Eckermann 1981: 211). ${ }^{4}$ There can be no doubt that it was Erich Auerbach's concern, against the backdrop of the historical events of his time, to make his own contribution to a new era of world literature.

In doing so, he was conscious of the fact that historically speaking the "epoch of Goethean humanism" (Auerbach 1967: 302) had been

\footnotetext{
“eingreifende Veränderung der allgemeinen Lebensvoraussetzungen”.

"in ihrer ganzen Bedeutung erkennen”.

See Meyer-Kalkus (unpublished paper).

"National literature has not much relevance today, the epoch of world literature is now dawning, and everyone should do what he can to accelerate its arrival".
} 
very short-lived and that there were large and perhaps irreconcilable differences between the amount of knowledge that the author of Faust personally possessed and that which the state of research had attained by the mid-twentieth century:

Was Goethe am Ende seines Lebens von den Literaturen der Welt, vergangenen und gegenwärtigen, zu Gebote stand, war viel im Verhältnis zu dem, was zur Zeit seiner Geburt davon bekannt war; es ist sehr wenig, verglichen mit unserem gegenwärtigen Besitz (Auerbach 1967: 302). ${ }^{5}$

But how can any future philology do justice to this steadily growing mountain of facts, to what already in Auerbach's time was a tremendously expanded store of knowledge, if philology should wish to treat that which - based on its claim to be an "historical discipline" - it must recognize as the "inner history of the last millennia", namely "the history of humanity's successful progress toward self-expression" (Auerbach 1967: 303). ${ }^{6}$ The unmanageable flood of data long ago heightened the pressure toward specialization in the area of philology:

Wer sich nicht konsequent auf ein enges Spezialgebiet und auf die Begriffswelt eines kleinen Kreises von Fachgenossen beschränkt, der lebt in einem Getümmel von Ansprüchen und Eindrücken, denen gerecht zu werden nahezu unmöglich ist. Und doch wird es immer unbefriedigender, sich nur mit einem Spezialgebiet zu befassen; wer heute etwa ein Provenzalist sein will und nichts anderes beherrscht als die einschlägigen Teile der Linguistik, der Paläographie und der Zeitgeschichte, der ist kaum auch nur noch ein guter Provenzalist (Auerbach 1967: 303). ${ }^{7}$

Thus did Erich Auerbach state the central dilemma confronting not only philology, the arts and humanities but also the natural sciences. He recognized at the same time that if philology did not wish to cede a good bit of its social relevance, then specialization in solely one disci-

5 "The amount of world literature, both past and present, at Goethe's disposal toward the end of his life was great in relation to what was known at his birth; it is very little by comparison with what we presently possess".

6 "die innere Geschichte der letzten Jahrtausende [...] die Geschichte der zum Selbstausdruck gelangten Menschheit”.

7 "Those who would not severely restrict themselves to a narrow and specialized field and to the conceptual world of a small circle of specialist colleagues, live amid a turmoil of claims and counterclaims and impressions to which it is nearly impossible to render full justice. And yet it becomes increasingly less satisfying to occupy oneself with only a single specialty; whoever today would be a specialist in Provençal studies and has mastered nothing more than the pertinent contemporary history and the relevant linguistic and paleographic aspects, can hardly even be called a good Provençal specialist”. 
pline would be insufficient. The necessity for a - as we today would formulate it - transdisciplinary orientation spanning various specialty fields was thus proclaimed; and this at the same time draws attention to the fact that already in Auerbach's time the pressure to specialize was of a double nature. For on the one hand it obliged scholars to undertake research within the constantly differentiating or - as Auerbach often stated it - ramifying disciplines, while at the same time there also existed pressure toward forms of specialization that endeavored to cut across disciplinary boundaries. How else could Auerbach himself have been able to tackle so self-evident and yet at the same time so bold and even audacious a project ${ }^{8}$ as an investigation into "The Representation of Reality in Western Literature?”.

Specialization is therefore - in an extension of Auerbach's proposed "Philology of World Literature" - to be interpreted as a mobile concept, as a term of movement, and not exclusively as disciplinary "ramification" and a disciplined one-way street. Or as Auerbach formulated it during his teaching stint at Yale:

Es handelt sich also um Spezialisierung; aber nicht um Spezialisierung gemäß den überkommenen Einteilungen des Stoffes, sondern um eine jeweils dem Gegenstand angemessene, und daher immer wieder neu aufzufindende (Auerbach 1967: 309). ${ }^{9}$

Thus does specialization have not only a progressive metaphorical function in proceeding from the "general" to the "particular", from the "broad" to the "narrow", or even from the "superficial" to the "deep", but it can carry out the most diverse movements so long as these are adequate to the specific construction of the object and are verifiable in their discursive design. And the specializations making for creative and innovative scholarship are precisely those that cut across the "conventional divisions of the material". For scholarly creativity according to brain specialist Wolf Singer - can be described as the capacity "to see together what has never been seen together before" (Singer 2003: 108). ${ }^{10}$ But specialization in an area not yet seen together (and not merely written together) in its entirety demands an

8 See Ette (2004a: 57-96).

9 "We are speaking here of specialization; though not according to conventional divisions of the material but rather a specialization that is always appropriate to the respective object and which is therefore always to be newly discovered".

10 "etwas zusammenzusehen, was bisher noch nicht zusammengesehen worden ist”. 
equal measure of flexibility with regard to the objects and the methods of researching them, and still more relational mobility as well as a mobility that puts things into a relation with one another.

Auerbach - who was born in Berlin in 1892 and died in the U.S.A. in 1957 - deeply regretted that precisely that "which earlier epochs ventured to determine, namely man's place in the universe", ${ }^{11}$ had long been "remote" from the research agenda of his time (Auerbach 1967: 310). Thus may one without exaggeration assert that this scholar of Romance languages and literatures was preoccupied with achieving a world consciousness ${ }^{12}$ in the fullest sense - a world consciousness whose emergence would be assisted by Auerbach's concept of a philology of world literature. This also explains why in the last section of his essay Auerbach issued a programmatic call for a philology that was not restricted to a one-sided specialization or one that was understood as such:

Jedenfalls aber ist unsere philologische Heimat die Erde; die Nation kann es nicht mehr sein. Gewiß ist noch immer das Kostbarste und Unentbehrlichste, was der Philologe ererbt, Sprache und Bildung seiner Nation; doch erst in der Trennung, in der Überwindung wird es wirksam. Wir müssen, unter veränderten Umständen, zurückkehren zu dem, was die vornationale mittelalterliche Bildung schon besaß: zu der Erkenntnis, daß der Geist nicht national ist (Auerbach 1967: 310). ${ }^{13}$

Unmistakable in this passage is the degree to which the experience of exile, of "separation", entered into the concepts and research of a scholar whose most important work emerged from the experience of

11 "was frühere Epochen wagten, nämlich im Universum den Ort der Menschen zu bestimmen".

12 See Ette (2002) as well as (2004b). Erich Auerbach was well aware of the semantical multi-layeredness of the "world" concept, and rightfully pointed out the "great task of making people conscious of their own history; and yet this is so very insignificant, even a renunciation, when one calls to mind that we are not only on earth but in the world, in the universe" ("große Aufgabe, die Menschen in ihrer eigenen Geschichte ihrer selbst bewußt zu machen; und doch sehr klein, schon ein Verzicht, wenn man daran denkt, daß wir nicht nur auf der Erde sind, sondern in der Welt, im Universum” [Auerbach 1967: 310]).

13 "In any event, our philological homeland is the earth; the nation can no longer make that claim. Certainly the most precious and indispensable thing that the philologist inherits is the language and culture of his nation; yet it can only be effective in its separation therefrom, in its surmounting of it. Amidst changed circumstances, we must return to that which the pre-national medieval culture already possessed; we must return to the realization that the mind is not national”. 
migration and exile and was only successful because this forced change of place in the universe made him particularly sensitive to both the world-relevant and worldwide dimension of literature. ${ }^{14}$ Erich Auerbach knew full well the extent to which any philology so conceived would be necessarily exposed to the "tumult of claims and counter-claims and impressions" ("Getümmel von Ansprüchen und Eindrücken” [Auerbach 1967: 303]), while being simultaneously aware that the renunciation of such a transversal and transdisciplinary definition of the task of philology would ultimately bring about its implosion, its uncreative surrender and descent into meaninglessness. For renouncing to the tumult of claims could only imply renouncing to any claim of its own of being effectual beyond ever more narrowly drawn disciplinary parameters, as well as to the claim of investigating the current place of man in the universe. It was here that Auerbach felt an obligation to "the passionate disposition that drives an albeit small number (as always) of gifted and original young individuals to take up philological-intellectual history", ${ }^{15}$ and he had no doubt as to its "significance and future” (“Sinn und Zukunft” [Auerbach 1967: 302]).

The meaning and consequences of Auerbach's ground-breaking attempt to plot a new direction for philology can be as little overlooked as his partial misreading (from our present-day vantage point) in the sphere of literature and culture - a misreading which, from an U.S.-American postwar perspective, was completely understandable, but which presupposed a rapidly increasing planetary homogenization that entailed the phenomenon of "our earth, which is the world of world literature", ${ }^{16}$ becoming ever "smaller" and experiencing a diminution in "variety" (Auerbach 1967: 301). The author of Mimesis knew himself to be in accord with his contemporaries as well as with contemporary scholarship when he expressed his fear that a global dedifferentiation process might iron out and remove any cultural distinctions and developmental processes. What others greeted as a desirable standardization was seen by Auerbach as a fundamental threat to cul-

14 See the work of Edward Said in connection with his translation of Auerbach, namely Auerbach (1969).

15 "leidenschaftlichen Neigung, die nach wie vor eine zwar geringe, aber durch Begabung und Originalität ausgezeichnete Anzahl junger Menschen zur philologisch-geistesgeschichtlichen Tätigkeit treibt”.

16 "Unsere Erde, die die Welt der Weltliteratur ist". 
tural diversity - in particular when it came to world literature. For "thousands of reasons known to everyone", asserted Auerbach, "the life of people everywhere on the planet" was becoming standardized and was marked by the same "modern ways of life" that had their point of origin in Europe (Auerbach 1967: 301). But did life and ways of life actually grow ineluctably more uniform on a global scale? The half century since the publication of Auerbach's pioneering essay has shown us to what degree the still observable homogenization process is accompanied and counter-balanced by an opposing development of cultural heterogenization. This highly complex double movement has made the question as to the coexistence of different cultures in the world the (survival) question of the twenty-first century. Today there is no real call for us to inure ourselves to Auerbach's notion "that on a uniformly organized earth only a single literary culture - indeed, in a comparatively short period of time, only a few literary languages, soon perhaps only one - could remain alive” (Auerbach 1967: 301). ${ }^{17}$ Would this analysis correspond to actual developments, then in fact "the notion of a world literature would at once be realized and destroyed" (Auerbach 1967: 301). ${ }^{18}$ The reduction to a Singular would take the place of concretely experienced diversity.

Such a viewpoint, of course, is not in itself sufficient. Against the backdrop of the current fourth phase of accelerated globalization, it is necessary to keep in view the manifold world-literary developments and to focus above all on those dynamic processes that have gone largely unobserved or have been considered irrelevant and marginal, enfolded as they are within the hitherto bipolar and antagonistic distinction between world and national literature. For the question as to what can be preserved of the diversity should not be directed at the rather static concept of national literature, whose process is considered chiefly as a relatively autonomous (national) history that is to be addressed and dealt with by individual disciplines specializing therein; but rather, in the face of an immobile administrative philology, it is necessary to depict as fundamentally complex processes of movement

17 “daß auf einer einheitlich organisierten Erde nur eine einzige literarische Kultur, ja selbst in vergleichsweise kurzer Zeit nur wenige literarische Sprachen, bald vielleicht nur eine, als lebend übrigbleiben”.

18 "[wäre] der Gedanke der Weltliteratur - in einem höchst reduzierten und Goethe fernen Sinne - zugleich verwirklicht und zerstört”. 
those literary networks that cut across linguistic, national and disciplinary lines and which are no longer adequately represented by individual philologies, particularly when they devote themselves to a single language or literature. The complexity of these literary networks cannot be carved up into a sum of its individual parts, ${ }^{19}$ for the movement, the vectorial component, cannot be "filtered out".

But such movement and network processes are not simply to be classified as $a$ national literature or the world literature. ${ }^{20}$ Placed next to (and sometimes in opposition to) the Singular - i.e. the supposed singularity and static identity - of such concepts, we have to develop dynamic concepts of movement within the framework of mobile specialization. Thus, in what follows, our concern is not with a philology of world literature but a relational investigation within the framework of a philology of world literature. World literature, however, can be seen as neither the sum of national literatures nor as a world literature solely shaped by homogenization processes. National literary, linguistic, and disciplinary lines of demarcation should neither be lost sight of nor expunged from the investigation; world literature, in its vectorial multi-dimensionality, should be conceived within a discontinuous and post-Euclidean fractal space. Important in the context of a (yet to be configured) fractal geometry of world literature are not so much the boundaries and lines of demarcation as the methodologies and communication forms, and less the territorial than the trajectorial and vectorial dimension from a transregional, transnational and transareal perspective. From such a precise, multivalent and simultaneously mobile vantage point, one could succeed in seizing the new differentiation processes as well as the continuing de-differentiation processes in such a way that between (and beyond the sharp contrasts of) homogenization and heterogenization the creative scope of world literature in its vectorial dimension is recognizable. Then the philologies would transcend the mere administration of literature and make a contribution to helping define man's place and existence in the universe.

19 According to Friedrich Cramer, apart from relative unpredictability and a basic irreversibility of all processes, fundamentally complex systems possess the character trait "that the whole is more than the sum of its parts" (see Cramer 1996: 223).

20 The problems entailed by such a procedure can be seen in the rather carefree Francocentric study of Pascale Casanova (1999). 


\section{Dialectic of Enlightenment as a Dialectic of Homelessness}

In Auerbach's "Philology of World Literature", it is not contingent that he concludes his reflections on the "world" concept - falling back on Hugo von St. Viktor - with the theme of exile - "mundus totus exilium est" (Auerbach 1967: 319). ${ }^{21}$ And it was with great care that in the opening pages of what is certainly his most successful book today he chose to recall the figure of Odysseus who - particularly from the perspective of Auerbach's exile in Istanbul at the time - betrays a self-portrait of the Jewish émigré. For Odysseus embodies the exile experience of being driven hither and thither in a broken, fractal space while yet still in possession of that last glimmer of hope for a possible homecoming, that re-acknowledgment of one's person whose trigger is his very wounding and injury - "The Scar of Odysseus" (title of the famous first chapter of Mimesis).

Almost exactly contemporaneous with Erich Auerbach's reflections on Dargestellte Wirklichkeit in der abendländischen Literatur was Max Horkheimer's and Theodor W. Adorno's Dialektik der Aufklärung (Dialectic of Enlightenment), written between 1941 and 1944, and 500 copies of which were distributed in the latter year "to friends" before these "Philosophische Fragmente" ("Philosophical Fragments") could be published as a book under its definitive title in 1947 by the Amsterdam émigré press Querido. ${ }^{22}$ Not only in their first excursus "Odysseus oder Mythos und Aufklärung” ("Odysseus or Myth and Enlightenment”) but also in the Dialektik der Aufklärung are present the travel movements of the Homeric hero, whose figure often appears where one might have least expected it. Time and again Odysseus, who is constantly plunging into new adventures with his companions, comes to the fore and presents himself - as for example "in the face of the Sirens" as a "premonitory allegory of the dialectic of Enlightenment" (Horkheimer/Adorno 1986: 41). ${ }^{23}$ According to Horkheimer and Adorno, The Odyssey is "testimony to the dialectic of Enlightenment" (Horkheimer/Adorno 1986: 50) ${ }^{24}$ and in its sundering of epic

21 See also the entry "Exil”, in Auerbach-Alphabet (2004).

22 See Habermas (1986: 277). For the story of the work's composition from November 1941 to May 1944, see Habermas (1986: 278-281).

23 “ahnungsvolle Allegorie der Dialektik der Aufklärung".

24 “Zeugnis [...] von der Dialektik der Aufklärung”. 
from myth finally denotes a loss, the singing of the "Wanderings of Odysseus" already being the "wistful stylization of that which can no longer be sung", ${ }^{25}$ and the "hero of the adventure" proving himself as the "ur-specimen of precisely that bourgeois individual whose quintessence arose from this self-assertion of an integrated epic and myth, whose original prototype was the wanderer" (Horkheimer/Adorno 1986: 50). ${ }^{26}$ Hence - and here one can find many surprising parallels to Auerbach's reading of the Homeric epic - "the venerable cosmos of the meaning-filled Homeric world" ${ }^{27}$ is revealed as "achievement of ordering Reason, which destroys the myth using the rational order in which it [the myth] is reflected" (Horkheimer/Adorno 1986: 50). ${ }^{28}$

This stimulating new interpretation and reading of the figure of cunning Odysseus, which was likely owing "primarily to Adorno" (Habermas 1986: 287) is of major significance for our analysis. If Auerbach reads the Odyssey as at once a complement to and in contrast with the Bible, Horkheimer and Adorno read the adventure of Odysseus against a historical-philosophical backdrop that is placed to no lesser degree than the Holy Writ - in a "world-historical and world-historical-interpretive connection” (Auerbach 1982: 19). ${ }^{29}$ This, just like the worldwide claims of this philosophy, is obvious from the fulminating start of the book:

Seit je hat Aufklärung im umfassendsten Sinn fortschreitenden Denkens das Ziel verfolgt, von den Menschen die Furcht zu nehmen und sie als Herren einzusetzen. Aber die vollends aufgeklärte Erde strahlt im Zeichen triumphalen Unheils (Horkheimer/Adorno 1986: 9). ${ }^{30}$

Against the background of an historical and historical-philosophical situation in which "not merely the activity but the purpose of science and scholarship has become questionable" ${ }^{\text {"31 }}$ entirely like "the restive

25 “sehnsüchtige Stilisierung dessen, was sich nicht mehr singen läßt”.

26 "Urbild eben des bürgerlichen Individuums, dessen Begriff in jener einheitlichen Selbstbehauptung entspringt, deren vorweltliches Muster der Umgetriebene abgibt”.

27 "der ehrwürdige Kosmos der sinnerfüllten homerischen Welt".

28 "Leistung der ordnenden Vernunft, die den Mythos zerstört gerade vermöge der rationalen Ordnung, in der sie ihn spiegelt.”

29 "einen weltgeschichtlichen und weltgeschichtsdeutenden Zusammenhang".

30 "In the widest sense of progressive thinking, Enlightenment has always aimed at removing fear from the lives of people and setting them up as masters. But the fully enlightened earth is irradiated with Calamity Triumphant”.

31 " nicht bloß der Betrieb sondern der Sinn von Wissenschaft fraglich geworden [ist]”. 
self-destruction of the Enlightenment", "which has long been evident, the authors in their foreword dated "Los Angeles, California, May 1944" (Horkheimer/Adorno 1986: 7) attempted to elaborate more clearly that "germ of retrogression" 33 which was contained within Enlightenment thought itself and "which today occurs everywhere" (Horkheimer/Adorno 1986: 5). ${ }^{34}$ This germ is the reason why humanity "has sunk into a new kind of barbarism" (Horkheimer/Adorno 1986: 1$)^{35}$

Horkheimer's and Adorno's work on myths ${ }^{36}$ as work on the return of the Enlightenment in the form of mythology and of civilization in a barbaric guise parallels ideas of Walter Benjamin's as they appeared in his "On the Concept of History", which in 1941 was saved for posterity by Hannah Arendt and placed in the possession of Adorno:

Es ist niemals ein Dokument der Kultur, ohne zugleich ein solches der Barbarei zu sein. Und wie es selbst nicht frei ist von Barbarei, so ist es auch der Prozeß der Überlieferung nicht, in der es von dem einen an den andern gefallen ist (Benjamin 1980a: 696). ${ }^{37}$

Adorno's and Horkheimer's Dialektik der Aufklärung positions itself within "the - despite Hitler - continued theoretical work of German emigrants” (Horkheimer/Adorno 1986: 7) ) $^{38}$ and thus blazes the trail for a kind of reading in which The Odyssey is not limited to being one of the "earliest representative testimonials to bourgeois-occiden-

32 “ rastlose Selbstzerstörung der Aufklärung”.

33 "Keim zu jenem Rückschritt”.

34 "der heute überall sich ereignet".

35 "in eine neue Art von Barbarei versinkt".

36 In the sense of Hans Blumenberg (1979).

37 "It is never a document of culture without it being at the same time one of barbarism. And as it itself is not free of barbarism, so too is the process of its being passed down from generation to generation not free". This quotation takes on an odd coloring when one applies it to "Prozess der Überlieferung" ("Process of Tradition") itself, whose historical-philosophic theses played such an important role in the development of the Frankfurt School. For the circumstances surrounding Hannah Arendt's handing over of the suitcase containing Walter Benjamin's manuscripts to the office of the Institute of Social Research (the former Frankfurt School, now having been established in New York), see Young-Bruehl (2000: 241sq.).

38 "der trotz Hitler noch fortgesetzten theoretischen Arbeit deutscher Emigranten”. 
tal civilization" (Horkheimer/Adorno 1986: 6). ${ }^{39}$ The so-interpreted theme from The Odyssey is itself interwoven with these reflections like Benjamin's theses - in fragment form. The "inner proximity of the material to the destiny of mankind after two world wars" (Frenzel 1983: 564$)^{40}$ left its stamp not only on literature but on philology as well as philosophy, on both philologists and philosophers.

It is therefore not surprising that Horkheimer (born in 1895 in Stuttgart as son of a Jewish industrialist) and Adorno (born in 1903 in Frankfurt am Main as son of a Jewish wine wholesaler), who both left Germany after Hitler's rise to power and eventually reached the United States after having passed through various way-stations en route, were, like Erich Auerbach, attracted to the peripatetic figure (Bewegungs-Figur) of Odysseus as a point of reference in a series of constantly changing life-constellations. For in their own peregrinations, the figure of Odysseus symbolized a certain hope. The "trembling castaway" in his own way "anticipates the compass", ${ }^{41}$ and his "powerlessness, to which no part of the sea remains unacquainted", 42 simultaneously aims at the "disempowerment of power(s)" (Horkheimer/Adorno 1986: 53). ${ }^{43}$ Also in these formulations there exists in the figure of Odysseus a double self-portrait - without being reduced of course to a merely autobiographical reflection. For Odysseus embodied for Horkheimer and Adorno a "knowledge wherein exists his identity and which allows him to survive" (Horkheimer/Adorno 1986: $53),{ }^{44}$ so that as a "knowing survivor" ${ }^{45}$ he is simultaneously one "who most daringly abandons himself to the threat of death, which makes him hard and strong” (Horkheimer/Adorno 1986: 54). ${ }^{46}$ The peripatetic figure of the knowing Odysseus is above all a mythic, largerthan-life figure of survival (überlebensgroße Überlebensfigur) providing a link to the "Old World".

39 “[eines der] frühesten repräsentativen Zeugnisse bürgerlich-abendländischer Zivilisation”.

40 “innere Nähe des Stoffes zum Schicksal der Menschheit nach zwei Weltkriegen”.

41 "zitternde Schiffbrüchige [nimmt] die Arbeit des Kompasses vorweg”.

42 “Ohnmacht, der kein Ort des Meeres unbekannt mehr bleibt”.

43 "Entmächtigung der Mächte".

44 "Wissen, in dem seine Identität besteht und das ihm zu überleben ermöglicht".

45 " wissend Überlebende[r]".

46 "welcher der Todesdrohung am verwegensten sich überläßt, an der er zum Leben hart und stark wird”. 
The Homeric hero stands not only for a knowledge of life but still more for a knowledge that serves as prerequisite for survival in the happenstance existence of the exile, while simultaneously upholding the claim of contributing something decisive to the disempowerment of power. But no less decisive is the fact that it is "homesickness"47 that gives birth to Odysseus' adventure. One's homeland is formed in league with settledness and fixed possessions (Horkheimer/Adorno 1986: 85), but for Horkheimer and Adorno it is not held captive to this notion of settledness (in contradistinction to the nomadic life); for according to them, one's "homeland is having escaped" (Horkheimer/ Adorno 1986: 86), ${ }^{48}$ and furthermore:

Rede selber, die Sprache in ihrem Gegensatz zum mythischen Gesang, die Möglichkeit, das geschehene Unheil erinnernd festzuhalten, ist das Gesetz des homerischen Entrinnens. Nicht umsonst wird der entrinnende Held als Erzählender immer wieder eingeführt (Horkheimer/Adorno 1986: 86). ${ }^{49}$

Just as in escape, there is an element of later having escaped, so also is the homeland preserved in the endless wanderings of exile. Even the recitation of dreadful events, "as if they were intended for purposes of entertainment", ${ }^{0}$ simultaneously makes for "that first emergence of horror" ${ }^{\text {51 }}$ whose memory is kept intact (Horkheimer/Adorno 1986: 86). It is first in having escaped that a homeland is again made accessible; however, there remains no access to one's initial condition, to one's "original" heritage and homeland. Only then can Odysseus, marked and marked out by his scar, emerge as the home-coming homeless one and as the homeless home-comer - as the personification of an unending dialectic of homelessness. He becomes the "model for a modern epic of homelessness as counterweight to fascist glorifi-

47 See Horkheimer/Adorno (1986: 85): "Daß der Begriff der Heimat dem Mythos entgegensteht, den die Faschisten zur Heimat umlügen möchten, darin ist die innerste Paradoxie der Epopöe beschlossen" ("That the idea of homeland is opposed to the myth, which the fascists wish to pass off as homeland - herein resides the chief inner paradox of the epic").

48 "Heimat ist das Entronnensein".

49 "Speech itself, language and its contrast to mythical song - the possibility of retaining the memory of the experienced calamity - is the law of Homeric escape. It is not for nothing that the escaped hero is always introduced as the narrator".

50 “als wäre es zur Unterhaltung bestimmt”.

51 “[läßt] zugleich das Grauen erst hervortreten”, 
cation of a cultural heritage such as the homeland mythology", ${ }^{52}$ just as exile would become the "conditio sine qua non of modern existence” (Segler-Meßner 2003: 75).

Certainly the exile experience of homo migrans ${ }^{53}$ is as old as humankind itself, and certainly homo sacer (Agamben 2003a) has always been numbered among the essential states of human experience, part and parcel of the conditio humana. And yet there is good reason to see migration and homelessness as specific to human existence and life-knowledge in the modern era. In this connection, one may fall back in a general way on Friedrich Nietzsche, who in Die fröhliche Wissenschaft (The Gay Science) - and primarily with reference to European modernity - linked homelessness with the disappearance of the Ideal and the transvaluation of all values. Notwithstanding, for Nietzsche the notion of "European" was inseparable from that of homelessness and migration:

Es fehlt unter den Europäern von Heute nicht an solchen, die ein Recht haben, sich in einem abhebenden und ehrenden Sinne Heimatlose zu nennen, ihnen gerade sei meine geheime Weisheit und gaya scienza ausdrücklich an's Herz gelegt! Denn ihr Los ist hart, ihre Hoffnung ungewiss, es ist ein Kunststück, ihnen einen Trost zu erfinden, aber was hilft es! Wir Kinder der Zukunft, wie vermöchten wir in diesem Heute zu Hause zu sein! (Nietzsche 1988: 628)

The expatriation from today, from the present, opens here a temporal dimension that can be linked with the experience of a ruptured and discontinuous time that - in the words of Hugo von St. Viktor - has turned all the world into exiles. And why should this not apply to precisely that continent which was beholden to the myth of Europa, of a displaced and ravished migrant, the homeless place that Europe had become?

52 "Modell einer modernen Epik der Heimatlosigkeit als Gegenentwurf zur faschistischen Glorifizierung der Wurzellosigkeit wie der Heimat-Mythologie”.

53 In the words of Klaus Bade (2000: 11): “There has been 'homo migrans' as long as there has been 'homo sapiens'; for wanderings are as much a part of the conditio humana as are birth, procreation, sickness and death".

54 "Among Europeans today there is no dearth of those who have a right, as a mark of distinction and in an honorable sense, to call themselves homeless - it is to them I expressly impart my secret wisdom and gaya scienza! For their lot is hard, their hope uncertain; it is no mean feat to devise consolation for them - but what use is it! We children of the Future, how we would wish to have a home in the here and now!” (see also Ette 2001). 
But critical to our approach from this perspective is the dialectic of homelessness which runs throughout Horkheimer's and Adorno's Dialektik der Aufklärung and which is the unmistakable thrust of both this book and Auerbach's Mimesis. This dialectic grew from the epoch-specific experience of two world wars, but above all from an anti-Semitism that via National Socialism pursued the so-called Final Solution of the so-called Jewish Question and which in their "concluding" chapter Horkheimer and Adorno endeavor to explore. Did not Walter Benjamin, in the eighth of his historical-philosophical theses - half a century before Giorgio Agamben -, unequivocally argue the idea that,

Die Tradition der Unterdrückten belehrt uns darüber, daß der "Ausnahmezustand”, in dem wir leben, die Regel ist. Wir müssen zu einem Begriff der Geschichte kommen, der dem entspricht. [...] Das Staunen darüber, daß die Dinge, die wir erleben, im zwanzigsten Jahrhundert "noch” möglich sind, ist kein philosophisches. Es steht nicht am Anfang einer Erkenntnis, es sei denn der, daß die Vorstellung von Geschichte, aus der es stammt, nicht zu halten ist (Benjamin 1980a: 697). ${ }^{55}$

But if the historical concept must be changed - a concept which declares a state of emergency that phenomenon which has long been the norm and with a view to those far-reaching legal, philosophical and bio-political consequences which, in turn, according to Giorgio Agamben, paradoxically characterize the state of emergency (stato di eccezione) as a paradigm of political rule in the modern era ${ }^{56}$ - then, as a logical consequence, any history of literature that proclaims everything a state of emergency that is not in conformity with what is seen as the universal schema of national literature, must be fundamentally rethought and altered. For not "only" in the political, bio-political and economic spheres but also in those of culture and more specifically literature, have persecution and exile, diaspora and migration - still stubbornly dismissed as states of emergency and relegated to those

55 'The tradition of the oppressed teaches us that the 'state of emergency' in which we live is the rule. We must arrive at a concept of history that corresponds to this rule [...]. The astonishment that the things we are experiencing in the twentieth centure are 'still' possible is not of a philosophical nature. Such astonishment is not at the beginning of an insight unless it is one that stems from an untenable idea of history”.

56 Agamben (2003b: 10): “[...] lo stato di eccezione si presenta come la forma legale di ciò che non può avere forma legale”. 
certain conceptual pigeonholes especially created for them - long been the rule in a worldwide context. It is no coincidence that the fact of the exception becoming the rule and of homelessness becoming a prime point of reference in life, in reading and in writing, is to be understood more clearly within the sphere of warring conflicts and the totalitarianism of the twentieth century, of international anti-Semitism and the Shoah. Insight into the fact that Entronnensein - as formulated in the Dialektik der Aufklärung - cannot be separated from the knowledge that Horkheimer gave word to in 1944, namely that, "actually anyone could be in a concentration camp". ${ }^{57}$ Both are products of an epistemological process based on the perception of a historical situation and both - in the Benjaminian sense - at first portray a "picture" that "flashes in the moment of its recognition" (Benjamin 1980a, from the fifth thesis) or "at the moment of danger"59 (Benjamin 1980a, from the sixth thesis). That this "flash" occurred almost in the exact same "moment" for thinkers as diverse as Auerbach, Adorno, Benjamin and Horkheimer ${ }^{60}$ is as little owing to chance as the fact that Walter Benjamin chose to depict History using a soon-to-be famous "picture" that was apposite for a still "unredeemed humanity" (Benjamin 1980a: 694) ${ }^{61}$ namely a "picture of Klee's, whose title goes by the name of 'Angelus Novus"” (Benjamin 1980a: 695): ${ }^{62}$

Der Engel der Geschichte muß so aussehen. Er hat das Antlitz der Vergangenheit zugewendet. Wo eine Kette von Begebenheiten vor uns erscheint, da sieht $e r$ eine einzige Katastrophe, die unablässig Trümmer auf Trümmer häuft und sie ihm vor die Füße schleudert. Er möchte wohl verweilen, die Toten wecken und das Zerschlagene zusammenfügen. Aber ein Sturm weht vom Paradiese her, der sich in seinen Flügeln verfangen hat und so stark ist, daß der Engel sie nicht mehr schließen kann. Dieser Sturm treibt ihn unaufhaltsam in die Zukunft, der er den Rücken kehrt, während der Trümmerhaufen vor ihm zum Himmel

57 See Habermas (1986: 281).

58 "Bild [das] im Augenblick seiner Erkennbarkeit eben aufblitzt".

59 “im Augenblick einer Gefahr aufblitzt”.

60 For the familiarity with and closeness to Walter Benjamin of the authors of Die Dialektik der Aufklärung, with a view to the historical-philosophic interrelation of myth and the modern era, see Habermas (1986: 282sq., 286sq.).

61 "[nicht] erlösten Menschheit”.

62 "Bild von Klee, das Angelus Novus heißt”. 
wächst. Das was wir den Fortschritt nennen, ist dieser Sturm (Benjamin 1980a: 697sq.). ${ }^{63}$

Like Adorno and Horkheimer and Auerbach, Benjamin chose a figure in motion (Bewegungs-Figur); albeit for his Angel of History - in contrast to Odysseus - the way back, the path leading to an original paradise, to the homeland, is debarred to him and has become unviable. And yet his gaze is as little averted from it as is that of the crafty Greek. Both figures are driven by storms while still having a point of orientation. Yet whereas the home-coming homeless one is still granted the possibility of a final homecoming to Penelope's loom, and his erratic and disconnected wanderings describe a rondo pattern, in (and with) Benjamin's eyes Klee's angel is only granted the possibility of movement toward a stormy future that is a regression into the future without any return, erratic while yet still as linear as a one-way street.

The philological and world-literary reflections of Erich Auerbach, the critical philosophical-scientific fragments of Max Horkheimer and Theodor W. Adorno as well as the historical-philosophical and progress-critical theses of Walter Benjamin show to what extent the dimension of homelessness in the mid-twentieth century powered certain insights and in how fundamental a way writing and thinking and even life itself had for the longest time been informed by a homelessness that in the sphere of ever more brutal wars and mass expulsions, of anti-Semitism and the Shoah, had become the rule. That the generation-specific experience of authors like Hannah Arendt, Victor Klemperer and Werner Krauss has, as it were, been continued in a transgenerational way since the end of the twentieth century (the century of migrations) within changed historical and socio-cultural circumstances is hardly surprising when one considers that their experience is indissolubly linked with just these new circumstances and life-contexts. The dialectic of Enlightenment still operates as a dialec-

63 "The Angel of History must appear so. He has turned his countenance to the Past. Where a chain of events appears before us, he sees only a single catastrophe that unremittingly piles rubble upon ruins and flings them at his feet. He would like to linger, wake the dead and piece together that which has been destroyed. But a storm blowing from Paradise catches his wings and is so strong that the angel cannot fold them. The storm drives him unceasingly into the Future, to which his back is turned, while the heap of rubble before him grows Heavenward. That which we call Progress is this storm”. 
tic of homelessness. Odysseus and the Angel of History have in a sense disappeared, even if at the end of the twentieth century these wandering figures have been newly constituted. If one's homeland is Entronnensein, then escape is a way and, in fact, many ways to configurate and picture one's homeland, to capture it in a (motion) picture.

If one can understand the state of emergency as a normative case and the concentration camp as a bio-political paradigm of modernity, then homelessness - in a time when the storm continues to blow the Benjaminian Angel of History before it and ever further afield from Paradise - has become a very harsh experience for those with no fixed abode. Even when investigation of the supposed state of emergency in the sphere of literature in a time of post-colonial theory construction increasingly encompasses phenomena such as diaspora and exile, migration and transmigration, it will still be a good long while before the literature of homelessness - or rather, the literature with no fixed abode - will be understood and recognized as more than just a peripheral, marginal element in world literature. Not only the concept of history but also the concept of that which is linked to the historical idea in a fundamental yet complex way - namely the concept of literature - must change if an adequate understanding of literary writing in the twenty-first century is to be achieved. For there is no doubt that this literature will have increasingly to be conceived and understood as literature without a fixed abode. The wings of the Benjaminian angel are still spread wide and the storm has increased in force. It may well be that not only the present concept of history but that of literature and philology as well are no longer sustainable.

\section{Literatures without a Fixed Abode}

Within the globalizing but by no means egalitarian literary networks of the world - they are rather stamped with strong asymmetries - literature without a fixed abode is assuming a wider and increasingly important dimension. At the end of a century that was marked by dramatic migrations of an unprecedented scale, and on the basis of multifarious expulsions due to war, famine, economic and ecological catastrophes and as a result of political, racist and sexual persecution, there have been developments that have also, step by step, trans- 
formed the mapping of world literature in the passage from the twentieth to the twenty-first century and which continue to transform this literature at an accelerated rate. Intercontinental infrastructures and transnational labor markets, fundamentalist religious wars and "ethnic cleansing”, globalized money markets and mounting numbers of economic refugees along with other phenomena too numerous to mention have all brought about the situation in which previous centers have not only been relegated to the periphery but the former peripheral areas have long since shifted to the center and become culturally active there. However, the globalization of democracy and justice - as opposed to the globalization of that "Calamity Triumphant" alluded to by the authors of Dialektik der Aufklärung (Horkheimer/Adorno 1986: 9 ) - in an age of migration and interdependence has yet to arrive. ${ }^{64}$

The metropolises have become focal points of multicultural, intercultural and transcultural movements, by which the various kinds of cultural juxtaposition can be understood, the manifold types of established exchange between sharply distinctive cultures, and the diverse forms of a sort of nomadic interaction running athwart different cultures. Even if such phenomena cut across and overlay one another, it is important and in fact unavoidable in any investigation of world literature that one tease out conceptually the various movements of cultural juxtaposition, cooperation and entanglement. For otherwise one runs the danger - with regard to the metropolises as well as world literature - of not only conflating the opposed movements of cultural homogenization and heterogenization but of underestimating their complexity.

In all of these processes one is obliged to take into account that political and cultural crosscutting is not seldom accompanied by the invariable crosscutting of languages. Citing Hannah Arendt, Giorgio Agamben draws attention to the fact that rupture of the "continuity" between human being and citizen, between nativity and nationality, between one's birthplace and one's people - which in the twentieth century was increasingly visible and irrefutable - has plunged the "fiction of origin", in the context of modern nation-building, into a crisis (Agamben 2003a: 140). Refugees, stateless persons and mi-

64 See the very different approaches of Höffe (1999), Albert (2002) and Fraser (1997). 
grants shake the assumptions of a process of identity formation based on the nation-state that is predicated on the "naturalness" and "selfevident" character of supposedly homogeneous cultural, religious and linguistic communities. It was and is precisely in the sphere of literature that the creation of imagined communities as well as their discursive erosion play a significant role.

For quite some time now the mother tongue which someone has been "born into" no longer automatically means that this will be the language which a certain author actually uses in their long-term literary endeavors or if only from time to time. As one can migrate to another nation, so too can one migrate into a foreign national literature. Affiliation with two or more "national literatures" or writing in various languages serially or simultaneously is no more unusual than a change of citizenship or the possession of several passports at once. For quite some time now such phenomena have no longer been rarities, even if they may differ in degree and kind in the various literary regions of the world. It is precisely in zones of dense globalization that these developments are emerging on such a massive scale that the construction of homogeneous "national" culture and literature appears not only antiquated, but as a conscious ideology of re-nationalization. But what does this all mean in a world where the nation can no longer - in the sense of Erich Auerbach (1967: 310) - be the "philological homeland?”.

We are dealing here with developments that give Goethe's concept of "world literature" a completely new meaning, a meaning that unquestionably lies beyond not merely the nation-state but national literature as well, even if this latter concept continues to guide the whole apparatus of production, reproduction, distribution and reception. World literature is less settled and has increasingly adopted a nomadic template for thinking and writing. This vectorization of literary production also corresponds to what for the longest time has been an increased spatial and sometimes intercultural and transcultural mobility from the side of literary criticism and scholarship. In this respect, as previous examples have shown, since at least the mid-twentieth century the United States has for various reasons become not a melting pot (or even the salad bowl) for immigrants so much as a "meeting point" and platform for diverse developments in the worldwide literary network. In a certain sense, the U.S.A. has inherited the mantle of 
France and in particular Paris, or, as Henri Michaux once put it, "la patrie de ceux qui n’ont pas trouvé de Patrie” (Michaux 1956). ${ }^{65}$ Persuasive testimony to this fact is the enormous number of intellectuals, writers, scholars and scientists throughout the world who have had short or extended stays in U.S.A. or who live on both sides of the Atlantic or Pacific.

Writing that has no fixed abode and transcends national boundaries - and which in no way questions the existence of these boundaries, as it succeeds not infrequently in multiplying them - expands the concept of national literature through the growing presence of a literature that one often subsumes under that highly unsatisfactory rubric of "migrant" literature. In an article published in the U.S., regarding a Spanish translation of the German-language novel Das Leben ist eine Karawanserei (Life Is a Caravansary), which among other honors was awarded the Austrian Ingeborg Bachmann Prize in 1991 and whose author, Emine Sevgi Özdamar, was raised in Turkey -, Spanish writer Juan Goytisolo, who had forsaken his native Barcelona to make his first home in the Arab world, stressed how for many years he had been at pains to draw attention to the fact that soon a significant portion of German literature would be written by Turks, a major part of French literature would be penned by those from the Caribbean and the Maghreb, and a large share of English literature would be authored by Indians and Pakistanis (Goytisolo 1994). ${ }^{66}$ For a good long while now this fact has been incontrovertible, even if the general consensus among national literary institutions of scholarship and the media is to dismiss such developments as peripheral phenomena.

One can today affirm that Goytisolo's prognosis has indeed proven out in an amazingly short period of time and that it describes an important - if by no means sole - reality of contemporary writing at the start of the twenty-first century. Languages, according to Emine Sevgi Özdamar in an interview on the occasion of her receipt of the Kleist Prize, "are like instruments, you make music with them, vary them" (Özdamar 2004) ${ }^{67}$ She added:

65 Here quoted from Casanova (1999: 49).

66 See also Ette (2004a: 227-252).

67 “[Sprachen] sind ja wie Instrumente, man musiziert mit ihnen, kann abwechseln”. 
Von Nationalstolz kriege ich Allergien. Es reicht doch zu sagen, ich bin da oder dort geboren. Mehr nicht. Überhaupt, man müßte mindestens zwanzig Pässe haben, man weiß ja nicht, welches Land sich als nächstes mit welchem verfeindet. Oder einen Weltpaß. Oder keinen (Özdamar 2004). ${ }^{68}$

In a lecture at Berlin's "Haus der Kulturen der Welt” on her novel Les nuits de Strasbourg - composed in French in 1997 in the U.S.-American state of Louisiana and whose action takes place within two different time frames in French-Alsatian-German Strasbourg - the Algerian-born writer Assia Djebar asserted:

Without a homeland, without need of a heritage: for at least twenty years I enjoyed my nomadic existence, I felt comfortable and sometimes even at home in Barcelona, Venice, Freiburg im Breisgau, or in the metropolises of northern Europe, arriving in Paris, which I wished to discover [...].When a man or woman comes to Europe from the south and writes European literature, is that not a kind of reverse "exoticism"? The counterpart or parallel of the "Orientalism” craze among Europeans would for us be "Occidentalism” - why not? (Djebar 1998).

Here the fact has been signaled that for some time now European literature has no longer been the chasse gardée, the private preserve, of Europeans. Assia Djebar's avowal that her "writing longs for other places" (Djebar 1998) in no way implies a desire to relocate in terms of literary terrain, but rather to create a literature that is not solely defined by its terrain and its re-territorialization. The rebellion here against time-honored lines of demarcation is patently obvious; although (or for the very reason that) her writing deals intensively with certain specific places, for example Strasbourg during the period of its evacuation by French troops from September 1939 to June 1940, thus tackling a subject that has been largely avoided in both French and German literature. That is why literature without a fixed abode is not to be simply removed from consideration, for it cuts across traditional territorial lines as inherited from the nineteenth century in the spheres of literature and philology.

It is no accident that the development adumbrated by Goytisolo and inimitably personified by Djebar has accelerated its pace since the end of the twentieth century. This, however, should not deceive us

68 "I am allergic to national pride. It's enough to simply say that I was born here or there. Nothing more. You would really have to have at least twenty passports one never knows what country is going to be the enemy of what country next. Or a world passport. Or none at all”. 
into thinking that national literary categories, ascriptions and exclusionary mechanisms have disappeared or will be disappearing any time soon. And it is precisely the literary authorities and other people involved in the literary trade who will continue to make things difficult for authors like Emine Sevge Özdamar, whose work is sometimes not regarded as belonging to the sphere of Turkish literature by Turks; or José F. A. Oliver, whose writing is often not arrayed in the ranks of Spanish literature by Spaniards; or Amin Maalouf, whose books in the Arab world are sometimes not considered Arab literature. Authors whose work can be classified as literature without a fixed abode are the preferred objects of national literary (and now and then nationstate) expatriation. The instances of such are legion.

Those authors who dispose of no permanent residence in a territory supposedly their "own" often have a difficult time evading such exclusionary mechanisms. For both habitual cultural and literary border-crossers - frequently branded as border-violators, as smugglers or spies, as vagabonds, nomads and mercenaries, as freebooters, refugees and double agents - and inhabitants of the borderlands have always had problems being recognized in those countries where they were currently residing. Therefore it is little wonder that representatives of literature without a fixed abode - in contrast to those authors who at first glance can be easily subsumed under a single national literary rubric - are considered suspect and smack of the subversive.

And yet it is becoming increasingly difficult to dismiss migratory literature as well as other forms of literature without a fixed abode as "exceptional cases" and thereby disincorporate them. Moreover, national institutes of cultural foreign policy such as the Goethe Institut and the Instituto Cervantes have long recognized that literary "nomads" allow them to score points abroad and publicly demonstrate (and put to the test) the openness of their own societies. Until now, though, philologies have not formulated any satisfactory concepts that do justice to phenomena and developments that for some time now have been widespread within the international literary enterprise.

Our discussion of Erich Auerbach's thoughts concerning a philology of world literature should demonstrate that the conceptually contrasting notions of "national literature" and "world literature" - inherited from the nineteenth century - are no longer adequate in addressing those phenomena that in the wake of the totalitarianism, wars 
and persecutions of the twentieth century - and in particular the Shoah - have fundamentally changed the "normality" of the bases of thinking and writing and have made migratory writing into an international mass phenomenon. The conceptual lines of demarcation that Auerbach seismographically registered in his essay, against the background of his own life-experience, are in need of change and mobile specializations that can do justice to the vectorial imagination of literary writing processes and the dynamic dimension of artistic production at every level. Goethe's famous pronouncement that "national literature has not much relevance today" 69 and that the "epoch of world literature" is now dawning (Eckermann 1981: 211) ${ }^{70}$ is not to be simply adopted uncritically as a guideline to the changed conditions of the late twentieth and early twenty-first centuries, but is to be creatively transformed and adapted to these conditions. It is now time, in light of the fourth phase of an accelerated globalization, to bring the diverse products of world literature into relation with one another, to set them in conceptual motion by embracing literature without a fixed abode and thereby focussing attention on mobile, dynamic and transient figures in the context of a fractal, discontinuous and, as it were, post-Euclidean geometry of literature.

This means not only that in the future we should direct our chief attention more determinedly to the translation and transmission of literature and from this "external" perspective of movement to then enlightening the putative authorities of the various (national) literary realms; it also means that the respective literary languages and territories should be regarded as places for the immigration of "foreign" languages and "foreign" cultures, places in which the "foreign" becomes part of one's "own" while still not losing its "foreignness" within one's "own". It is especially important to investigate how such displaced elements become established and how the host (literary) language - in the sense of Walter Benjamin's reflections on "Die Aufgabe des Übersetzers" ("The Task of the Translator", Benjamin 1980b) - is transformed and enriched. To judge such processes solely as a sign of cultural homogenization or hybridization testifies rather to conceptual impoverishment. One of the important tasks of contem-

69 "Nationalliteratur [...] jetzt nicht viel sagen will”.

70 "Epoche der Weltliteratur". 
porary philology should be to document and fathom the dynamics, latitude and patterns of movement between both poles in a more precise way.

The observable increase in the volume of literature without a fixed abode has led to the situation - without the fact of it being broadcast hither and yon - that all aspects and elements of literary production have been set in motion in a far more radical and lasting way than ever before and that we are experiencing a general vectorization in every respect, including the area of national literary structures. Since in the post-modern era the temporal bases of our thinking and writing have, in comparison to the modern era, become weaker, while spatial concepts and thinking have increased in significance, today our attention should be focused on movement and migration as seminal traits of world literatures. A fully elaborated Poetics of Movement, however, has yet to emerge. Such an endeavor, though, would be very worthwhile, for it could bring to light, in all its complexity and variety, the vectorial imagination that lies behind much of today's writing.

For a good long while now, vectorization has comprised not only the themes and content of literature, their various presentations and representations of movement, but also their adoption by a wide spectrum of readerships on a global scale. This means that we can no longer, in an unreflective way - and this is by no means "only" a phenomenon of non-European and/or so-called post-colonial symbolic production - territorialize our cultures, but we must rather vectorize them and understand them as cultures in motion.

With its various overlays of space and movement, world literature allows one to observe and playfully test inclusionary and exclusionary processes, traditions and breaks with traditions, as well as the sequence of multicultural, intercultural and transcultural events, from various perspectives simultaneously. World literature mediates a world consciousness that accords with the state of affairs of our time, and it places at our disposal a certain life-knowledge that reductionist mappings - in which homogeneous cultural blocks stand hostilely opposed to one another and suggest a "clash of civilizations" (Huntington 1996) - are disclosed as the self-fulfilling prophecy and ideology of a strategy for achieving hegemony, an insistent extension of politics by other means. 
It is no coincidence that Horkheimer and Adorno see in the peripatetic figure of the crafty Odysseus the embodiment of a "knowledge that founds his identity and allows him to survive" (Horkheimer/ Adorno 1986: 53). ${ }^{71}$ During a period when the Enlightenment had taken a surprising turn into totalitarian violence, this configuration of survival knowledge that must reorient itself and learn new ruses emerged through those movements performed by the "knowing survivor" (Horkheimer/Adorno 1986: 54) as someone who is driven about within the Homeric world of alien and yet familiar powers. In the hermeneutics of this peripatetic figure of the migrant, a survival knowledge (Überlebenswissen) is stored that is not necessarily due to any authorial intention or even consciousness, but is accessible to us even today and can be adapted from outside of its original context. My thesis is that the figures in motion (Bewegungsfiguren) described by this peripatetic figure Odysseus are precisely those which facilitate the process of translation and adaptation; that within them exists an itinerary or grid of movement structured along lines of space and time which can also be employed as a spatial model of understanding within the context of other time-space settings and which can be adopted as life-knowledge within the narrative structure of one's own life. The Scar of Odysseus can symbolize the fact that such cannot succeed without injury and loss.

In this way, the reception and adoption of life-cum-survival knowledge itself brings forth a certain life-knowledge - and herein lies a good part of the political potential of literature - that can be placed in the effective service of society. A more intensive approach to literature without a fixed abode in the context of world literature can demonstrate that out of this social function new areas of knowledge and spheres of activity for the various philologies can arise that may be developed as soon as a predominantly static disciplining of philological disciplines is reduced in favor of mobile forms of specialization. If one can succeed in understanding the present phase of accelerated globalization as an extension of the earlier historical sequence of accelerated and decelerated phases, and if one is able to recognize in the current ordering of knowledge the history and thus plasticity of currents of knowledge, then one can achieve a new grasp

71 "Wissen, in dem seine Identität besteht und das ihm zu überleben ermöglicht”. 
of literary and cultural processes within a fractally configured space of movement that transcends not only the Goethean dichotomies of national and world literature. Seen against the contemporary historical and world-cultural background of the beginning of the twenty-first century, our considerations here in critical extension of Erich Auerbach's challenging reflections will hopefully make a contribution to a philology that has a distinct life-knowledge orientation.

\section{Figures of Vectorial Imagination in the Shoah Literature}

The historical development of literature without a fixed abode experienced a rapid increase in the twentieth century - in the sense of the previously largely taboo treatment of anti-Semitism, the Shoah and totalitarianism (and these beyond the context of National Socialism as well) as related themes ${ }^{72}$ - that represents still today one of the most important traditions of these littératures sans domicile fixe. Even the establishment of the state of Israel and the affiliated project of a kind of global re-territorialization have in no way succeeded in weakening the importance of these traditions. Rather, additional waves of emigration and immigration were triggered in the Middle East, the worldwide consequences of which can still be seen today.

At the end of Hannah Arendt's study of the univers concentrationnaire, she came to fear that "concentration camps and gas chambers" (Arendt 1991: 942) would continue to endure far beyond the brief life of National Socialism and other totalitarian regimes of the twentieth century:

Just as in today's world totalitarian tendencies can be found everywhere and not only in those countries with totalitarian rule, so too could these central institutions of total power very easily survive the toppling of all those totalitarian regimes with which we are familiar (Arendt 1991: 943).

Insofar as this survival (at least of concentration camps) throughout the twentieth century into the present day in diverse regions of our world has become an established fact - as numerous studies show and insofar as the concentration camp itself can with good (if not uncontested) reason be termed a "bio-political paradigm of the modern

72 Hannah Arendt was the first to break the taboo in her today still fascinating book Elemente und Ursprünge totaler Herrschaft (1991). 
era", ${ }^{73}$ then it is understandable why Shoah literature has become a transgenerational as well as transcultural and transhistorical phenomenon. Neither did the existence and infamy of concentration camps begin or end with the inhuman atrocities of Auschwitz and Buchenwald, Dachau and Mauthausen. The univers concentrationnaire did not cease to exist with liberation of the camps.

With the imminent deaths of the last survivors of the National Socialist concentration and extermination camps looming in the next several years, present discourse on the Holocaust and Shoah has increasingly focused on the notion of eyewitness testimony. ${ }^{74}$ All discussion and research axes that concern themselves with the world of the concentration camp would appear to intersect here. Paul Celan's often-cited verse "Niemand zeugt für den Zeugen" ("No One Bears Witness to the Witness") has become a point of reference for a debate concerning the approach to and legitimacy of eyewitness reports that is far from being brought to even a preliminary conclusion. Giorgio Agamben's statement that today, from an "historical viewpoint", we know "how the final phase of extermination transpired" in even the "smallest detail" (Agamben 2003c: 7), stands in opposition to his own reference to the fundamental conundrum that emerges with the question, "What of Auschwitz remains?": "The impossibility of bearing witness, the 'gap' in human speech must therefore collapse in on itself so that another impossibility of attestation can take its place - namely one that has no language" (Agamben 2003c: 35).

But beyond this conundrum, the analysis of figures on the move (Bewegungsfiguren) can throw an entirely new and different light on the construction of testimonial discourses in the Shoah literature, highlighting fruitfully those dynamics that leave their stamp upon literature without a fixed abode. For these hermeneutic figures of movement introduce a spatial model of understanding that reveals - on the strength of the aesthetic dimension of these texts - a cognitive function beyond the "impossibility of attestation", a cognitive function that can be intersected but not thwarted by the conundrum of attestation. In the following section, using four examples, we will investigate various

73 This is the title of the third and concluding portion of Agamben's Homo sacer (Agamben 2003a: 125).

74 See the extensive overview of research per this theme in the second chapter of Segler-Meßner (2003). 
figurations of the concentration camp along lines of vectorial imagination, thus allowing aesthetic access to this attestation which lies beyond a solely referential function. Consequently, the following brief analyses proceed from the conviction that in the testimonial discourses (Zeugendiskurs) one is able to locate a generative discourse (Zeugungsdiskurs) and process for literature without a fixed abode.

\subsection{Albert Cohen, or the Prefiguration of the Concentration Camp}

Let us first examine a short text by Albert Cohen (1895-1981), a text which until now has garnered little critical attention. ${ }^{75}$ Cohen is one of the outstanding Francophone authors of the twentieth century as well as being one of the most difficult to classify - in many respects. He was born on the small Greek island of Corfu in the Ionian Sea and grew up amid the Venetian dialect of the local Jewish community. Driven away from the island by fear of future pogroms, Cohen's parents settled their family in Marseilles. It was only after Cohen completed his university studies in Geneva that he exchanged his Ottoman passport for a Swiss one. Helvetian citizenship enabled him to not only visit relatives in Alexandria and to work at the "Bureau International du Travail” in Geneva, but also, as a Francophone writer, to flee the Germans and gain entry into England when the British consul in Bordeaux recognized him as the author of his famous novel Solal. Later, as an international diplomat, he succeeded in devising a passport for stateless persons and having it internationally recognized. He was no less proud of this passport success than he was of his novels penned in a language that was not his maternal one; novels that he authored under a name into which he had discreetly slipped an "h" upon acquiring his Swiss passport (as a resident of Geneva he became a citizen of Mellingen in the canton of Aargau) ${ }^{76}$

The life-experience of this progenitor of a stateless passport doubtlessly left its stamp on his literary œuvre. For similarly complex, "internationalized" careers (often in grotesque exaggeration) can be found in the figures of Cohen's stories, plays and novels. What makes these pieces so readable is not only the language, clothes and physical

75 See my extensive analysis in Ette (1999).

76 For a biography of Cohen, see the monograph by his friend Gérard Valbert (1990). 
descriptions of the characters, but above all the spatial sketches of life histories that turn into travel accounts. With the assistance of their movements in space, Cohen lays before his readers the map, as it were, of their personalities.

This is precisely the case with a haunting scene that appeared in Cohen's 1972 book Ô vous, frères humains, and which may have been a crucial key to his literary œuvre. Decades before, just months after the war's end in 1945, Cohen had published this scene in two parts in the influential exile periodical La France Libre under the title "Jour de mes dix ans" (Cohen 1945a/b). ${ }^{77}$ The following reflections are devoted to this germinal scene and genuine literary creation of Cohen's.

"Jour de mes dix ans" appeared on Cohen's fiftieth birthday and was the first publication in La France libre to carry his own name and not the pseudonym "Jean Mahan". The text is divided into a total of thirty-seven short sections, each bearing a separate heading. The first section is called "Souvenirs d'enfance", a title which is adjusted forthwith to read "souvenirs d'enfance juive" (Cohen 1945a: 193). Without here undertaking a detailed analysis of the text's characteristic use of both the first and third-person singular, one can assert that presented here is not the solipsistic individual seated in front of a mirror and looking backward into his past; rather, the narrator paints a picture in words that doubtless many other Jews would recognize. On the protagonist's tenth birthday and on his way home from school, he approaches a street-vendor hawking an all-purpose spot remover, who, after careful inspection of the young boy, tells him to be on his way:

Toi, tu es un Youpin, hein...tu es un sale Juif, tu es avare hein, ton père est de la finance internationale hein, tu viens manger le pain des Français hein, eh ben nous, on aime pas les sales Juifs par ici, c'est une sale race (Cohen 1945a: 193).

It is no accident that this key scene possesses not only an individual component but a collective dimension as well. For so too did Alain Finkielkraut - born in Paris in 1949 and an attentive reader of Cohen begin his (self-)critical and sometimes provocative piece on the Jewish self-image and the Jewish construction of identity, using Jean-Paul Sartre's Réflexion sur la question juive to inform a similar depiction of

77 An abridged version appeared in September of that same year in the journal Esprit. 
one's identity as a Jew being precipitated exogenously; it is first under the gaze of others, beset by a flurry of epithets, that the juif imaginaire is "born". ${ }^{78}$ And in alike fashion does Albert Cohen's "Jour de mes dix ans" also portray a moment of birth that transforms the boy on his tenth birthday into a Jew; the trap limned by Finkielkraut - "obligation de penser le judaïsme en termes de moi et d'identité” (Finkielkraut 1980: 215) - claps shut.

Symptomatic is the fact that Cohen's keynote scene of a person's coerced transformation into a Jew takes place on the street among a public that raises not a single voice in defense of the child. All of them are familiar with anti-Semitic propaganda and would appear to approve of it. In this open space there is no counter-discourse, the defenseless protagonist is abandoned to the exclusionary mechanism of the blond aggressor. The historical background to this episode, which forms the nucleus of "Jour de mes dix ans", was bled into the text and conveys the anti-Semitic atmosphere of a Marseilles that in 1905 was still caught up in the furor of the Dreyfus Affair; and the camelot does not forget, amidst the platitudes of his anti-Semitic discourse, to allude to it. $^{79}$

For the young boy, harshly excluded from the community, now begins a "migration" that after several short respites will find its (temporary) end in the last portion of the tale in the boy's parental home. After approaching the circle of spectators crowding around the streetvendor, there then follows a diametrically opposed, nonautonomous movement that casts the boy out of the community and into society at large. The youth wanders through the streets of Marseilles, walks along walls that double as Wailing Wall, and aimlessly traverses the indifferent crowd like a juif errant.

In the next section, "Un camp de concentration en miniature", the protagonist makes his way to the railroad station, whose trains - as is often the case in Cohen's work - symbolize the transportations into the concentration camps, a fate which also threatened the Jews of Marseilles after the German occupation of the Zone libre. The locus of this concentration camp en miniature is the train station lavatory, the place

78 Finkielkraut (1980: 10): “Crève, sale Juif!”.

79 This historical and mental-history dimension in Ô vous, frères humains is buttressed with additional details from the everyday life of that time, but which we are unable to explore here. 
to which the boy in his desperation retreats - and which one imagines to be rather unsuitable as a transitory space - so as to protect himself from the threatening outside world. The little boy has been driven from the community and already assigned his place in the (as of now still virtual) concentration and death camps, whose existence Cohen was first to learn of in English exile, and which he himself had been able to narrowly escape. The adult Cohen's later knowledge of this fact informs the situation of his ten-year-old protagonist, whose transformation into a Jew in Marseilles during the Dreyfus Affair shows the career of the Jewish people in their errance, while prefiguring the concentration camps in a projection that oscillates between 1905 and 1945, between recounted time and the time of recounting.

In the text itself are several "sequels" to the keynote scene in the streets of Marseilles. Repetition of the street-vendor's accusatory words quickly segue into a portrayal of the boy, who, with the help of his five fingers - standing for the five figures of Cohen's novel stages a private performance that transforms the lavatory, that "camp de concentration en miniature", into a venue of self-reflection and art. The protagonist lets his fingers dance about as the author himself has the figures in his series of novels dance to his plots. In the concentration camp itself the sphere of art is placed in opposition to the unbearable errance in a hostile external world and is a critical factor in warding off thoughts of suicide. Contained within Cohen's prefiguration of the concentration camps is the notion that the work of the artist is an expression and tool of the intractable will to live as well as one's survival-knowledge.

Naturally this fleeting interior space - a kind of transit camp - can offer only momentary refuge. The toilet attendant is impatient with the boy for having spent so much time in the station's privacy, and after she drives him out his aimless wandering begins anew. The narrator historically surcharges this episode, and, as in the case of the "Wailing Wall", it passes over into a culturally encoded collective history. Once more, from a short story emerges a long transgenerational history: "J'allai. Mon héréditaire errance avait commencé" (Cohen 1945b: 287). Shambling along the city's walls, for the first time ever, this definitive juif errant is able to decipher the words scribbled on them "Mort aux juifs!". Then the protean protagonist - skillfully emplaced en passant, as it were - goes from being an outcast to being a member 
of the Chosen People, in the truest sense "recognizing" himself as he passes by the mirror of a jeweler's shop and presents the reflection with his compliments (Cohen 1945b: 292). The abject exile has become a "prince de l'exil" (Cohen 1945b: 292).

At the end of the text and the protagonist's errance, this banished Chosen One returns to his parental home (and thus to the safe haven of inherited history): "ô doux ghetto privé de mon enfance morte" (Cohen 1945b: 294). ${ }^{80}$ Ensuing the death of childhood in the birth of a Jewish identity defined as an ostracized member of the Chosen People, the boy's return to his parental home gives his aimless wanderings and his stay in the "concentration camp" a rondo form that makes sense of the youth's transformation into a Jew. In his dialectic of homelessness, the Jewish Odysseus has indeed found his way home and the way to his own writing.

\subsection{Emma Kann, or Writing in the Concentration Camp and the Foreign Homecoming}

Emma Kann was born in 1914 in Frankfurt am Main. Several months after her Abitur, the Jewish Kann left Germany in September 1933 for England. In 1936, likewise overcoming myriad obstacles, she arrived in Belgium, and in 1940 fled before the invading German army into France. In the summer of that same year she was interned for some four weeks in the concentration camp of Gurs at the foot of the Pyrenees, which she was soon able to leave as a result of the chaotic situation pursuant to the French capitulation. After fleeing France in 1942, Kann reached Havana by way of Casablanca, and in March 1945 she was permitted entry into the United States, where she began to write in English in 1948 and where she lived - predominantly in New York - until her return to Germany in 1981. It was only with her reentry into Germany, as she noted in 1986, that she "returned to her mother tongue" (Kann 1986: 679).

Emma Kann's path through life is inseparable from her numerous lyric works, which have hitherto been published only piecemeal in a few volumes of poetry. In the year of her flight from Germany she

80 Albert Cohen's Geneva home was secured against the outside world through multiple locks and bolts. As many have testified, it was only with great reluctance that he ever left the seclusion of his dwelling. 
composed (but only decades later published) the poem "Heimatlos" ("Homeless", 1933), wherein the condition of exile found its initial literary expression in her verse:

Die Hügel sind nah, und das Meer ist mir nah,

Doch die Heimat ist mir so fern.

Es trennt mich von ihr nicht nur Hügel und Meer,

Das überbrückte ich gern.

Es trennt mich von ihr ein viel tieferer Schlund,

Als die kreisende Erde ihn kennt.

Es ist ihr Haß und es ist ihre Wut,

Was von der Heimat mich trennt.

Ich könnte nach Hause. Es ist nicht so weit,

Auf der Karte nicht so weit fort.

Doch zu Hause ist meine Heimat nicht mehr.

Fremd bin ich den Menschen dort.

Fremd bin ich dort und fremd bin ich hier

Und nirgends bin ich bekannt;

Und wandre ich auch über Hügel und Meer,

Ich finde kein Heimatland (Kann 1986: 67). ${ }^{81}$

Recurrence of the central lexemes "Heimat" (homeland) and "Haus" (home), "fremd" (alien) and "fern" (remote) underscores the loss of one's homeland as indicated in the poem's title; a homeland from which one is separated not by natural barriers but by historical experience, not by spatial distance but by an affective distancing from hate and rage. The resulting chasm that emerges between "home" and "homeland" appears as a process of alienation on a truly global scale: there is no way leading out of exile. The aimlessness of the wandering self suggests a homelessness that leads to a de-territorialization for which - to adduce Auerbach's concluding quotation of Hugo von St. Viktor - "mundus totus exilium est" (Auerbach 1967: 310). The self has not found a homeland in Entronnensein, in its having escaped, yet this functions as a point of departure for an errance that results in

81 "The hills are near and the sea is close by,/ Yet the homeland is so far away./ We are divided not only by hills and sea -/ These I would gladly traverse.// We are divided by a much deeper abyss/ Than the orbiting earth can know./ It is their hatred and rage/ That keeps the homeland and me apart.// I could go home. It is not so $\mathrm{far}$, On the map it is not so remote./ Yet my homeland no longer exists at home./ I am to the people there an alien.// I am an alien there and an alien here,/ And nowhere am I known;/ And even should I wander over hills and sea,/ I will not find a homeland". 
an abstract, interchangeable landscape - as shown in the tri-iteration of the words "Hügel” (hills) and "Meer" (sea).

In 1940, in those poems composed in the Gurs concentration camp, the movement abroad became a movement determined by others. ${ }^{82}$ Added to the homeless and aimless one in these poems is the irresolute one that drives the self forward, drives the self before it. The vastness of the world, as it appeared in the poem "Homeless", emerges in contrast to the spatial restrictions of the camp: the state of siege under which the ego finds itself leads to the creation of spaces of resistance that find their actual refuge beyond thought in the physical body of the self: "Dein Name darf nicht ins Gehirn,/ Dort schüfe er nur Schmerz" (Kann 1986: 69 [“An Jemand Fernes"]). ${ }^{83}$ The loss of a homeland space is followed by the loss of both a future and a past as illustrated in the poem "Frieden Im Krieg” ("Peace In War"), written shortly after Kann's release from the camp in 1940 (made possible by the collapse of France) and first published in 2004:

Das Gestern starb. Das Morgen starb.

Das Sehn vertrieb das Denken,

Und zwischen Tod und Tod geniesst

Es was die Stunden schenken (in Ette 2004a: 193) ${ }^{84}$

According to Emma Kann, in a letter of 16 October 2003, the poem with the characteristic title "Der Vagabund" ("The Vagabond") was "probably written shortly after [my] release from Gurs". ${ }^{85}$ In its second and final stanza, the poem stresses the absence of home and homeland, underscores the importance of landscape in the fascination it holds for the self, while yet discerning a final goal for all these wanderings:

Ich hab kein Haus, das mit mir geht,

Und keines, das im Fernen steht.

Ein hoher Berg, ein grünes Feld,

Ein schöner Blick sind meine Welt.

Doch ein Ziel hat auch meine Fahrt:

Die Freiheit, die mein Geist sich wahrt (Kann 1998a).

82 See Ette (2004a: 191).

83 "Your name may not enter the brain,/ For there it would only produce pain". This poem numbers among those composed in the Gurs concentration camp.

84 "Yesterday died. Tomorrow died./ Sight banished thought,/ And between death and death it enjoys/ What the hours grant it".

85 Letter from Emma Kann to the author (16 October 2003). 
At the latest, it is here in this passage that the dialectic of homelessness - after a process of de-territorialization - transmogrifies into what can with good reason be designated as a writing without a fixed abode. Escape, deportation, internment, release and renewed flight this time not to France but out of France and Europe into the New World this carved a path, as it were, between the poems, a path that in the three-stanza poem "Auf dem Meer I” (“At Sea I” from 1942; [Kann 1998b]) understands the Atlantic crossing, the existence of the self on the ship, to be a dying of "yesterday" ("Gestern") and "tomorrow" ("Morgen"), surrendered to a movement "driven by good and bad fortune" ("durch Glück und Unglück treibend") in which soon "my ego will lose itself in space" ("mein Ich im All verliert"). This theme of drifting about on the ocean and through space, in the outer space of an essentially uninhabitable and a-ecumenical world is also a theme present in the 1941 poem "Wir Lebten Einst Auf Einer Erde" ("Once We Lived On One Earth"), in which the one world has broken up into fragments. Here, the second stanza:

Bis das, was uns als Erde einte,

In Stücke fiel. Die Rinde sprang.

Nun treiben wir auf Weltenscherben

Allein des Schicksals Weg entlang (Kann 1986: 70). ${ }^{86}$

In an English-language poem composed in the United States in 1973, "The Land of My Childhood" is reprised once more as a theme in a similar way to the poem "Heimatlos" in which this land is not seen as a geographic entity, as a "shard of the world" ("Weltscherbe") but is regarded as omnipresent in its affective dimension: "Hatred and fear are always present,/ And one wrong step will set them free" (Kann 1986: 74). A single false move can unleash the (self-)destructive movements and injuries of the past; it can reopen old wounds and scars.

The poems of Emma Kann are testimony to a will to survive that flows over into a survival-knowledge in the same measure as one's own movement - and the act of being moved in both a spatial and emotional sense - can go from an aimless state to one with an itinerary that has homecoming as its goal. Naturally, that homecoming can

86 "Until that which united us as one earth/ Fell apart in pieces. The crust cracked./ Now we drift alone among the world's shards/ Following the path of fate”. 
no longer be to a distant land of childhood; rather, the homecoming is to a language that has become foreign to oneself while at the same time becoming an inhabitable and revivified homeless homeland. The 1981 poem "Heimkehr zur deutschen Sprache" ("Homecoming to the German Language") is language reflecting on language in the context of a foreign homecoming:

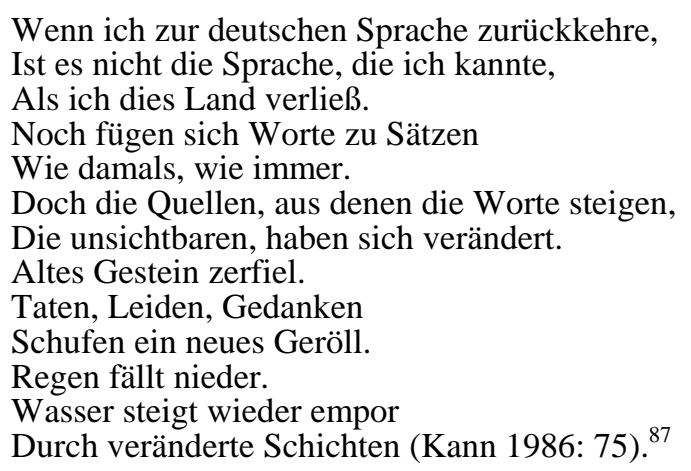

Once more it is the images of hills and sea, of land and water that appear integrated into a natural cycle of life. Yet the seemingly immutable is exposed to a process of erosion that is as irreparable as life itself. The de-territorialization of the homeland into language suggests that one's mother tongue is closely allied with "The Land of My Childhood" and does not in fact transcend time and place. The homecoming of Odysseus is a foreign homecoming. More: it is a homecoming to something of one's own as a foreigner. Emma Kann's writing is the ceaseless attempt to pursue the dialectic of homelessness through "altered strata" and give it a linguistic expression in which survival and Entronnensein become the sole conceivable homeland and the only homeland which one can write.

\subsection{Max Aub, or the Concentration Camp Lists}

Max Aub was born in Paris in 1903 to a German father and a French mother, neither of whom practiced the Jewish faith of their forebears.

87 "When I return to the German language,/ It is not the language I knew/ When I left this land./ The words still string together as sentences,/ As they did then, as always./ Yet the springs from which these words arise,/ The invisible ones, have changed./ Old rock decomposed./ Deeds, suffering, thoughts/ Created a new scree./ Rain falls down./ Water rises once more./ Through altered strata”. 
In 1914 the "boche" and his family were forced to flee France and settle in Valencia. Young Max learned Catalan and Spanish and early on adopted the latter as his literary language. He was active at various levels on the side of the Spanish republic in the Guerra Civil, and after his flight from France he was twice interned in the concentration camp of Le Vernet d'Ariège (from 30 May to 30 November 1940, and again from 6 September to 24 November 1941) ${ }^{88}$ and was later shipped in a cattle transport to the Algerian work camp in Djelfa, from which he successfully escaped to Mexico via Casablanca in 1942. He became a Mexican citizen in 1955. At the center of Aub's entire literary output is a single, ambiguous word, one which always went back to his experience of internment: campo. The ambiguity of this term, ${ }^{89}$ which reflects the camp experience from always new perspectives, opened a writing space that developed within the camp itself and later left its stamp on all of Aub's writings in exile. Aub's journal Diario de Djelfa underscores not only the fact that these poems were written down in the concentration camp at Djelfa on the Atlas plateau ${ }^{90}$ but also makes plain to all its readers that this writing in the concentration camp was necessary to the author's survival, and that otherwise he would have found the strains of this extreme situation unbearable (Aub 2001: 93).

Max Aub's oeuvre can be understood as a writing of movement that paradoxically concentrates itself in the concentration camp. After the French consul in Mexico rejected Aub's application for an entry visa into that country whose capital had been his birthplace, in an open letter dated 22 February 1951 to French president Vincent Auriol the exiled writer did not petition for aid, but rather for justice:

En marzo de 1940, por una denuncia, posiblemente anónima, fui detenido, a lo que supe después, por comunista. Conocí campos de concentración -París, Vernet, Djelfa- , cárceles -Marsella, Niza, Argel-, fui conducido esposado a través de Toulouse para ser transportado, en las bodegas de un barco ganadero, a trabajar en el Sahara y otras amenidades reservadas a los antifascistas (Aub 2002: 112).

Crucial for him was that he was still being handled along the lines of those index cards and lists that were drawn up on him by the police of the Vichy government: "Ya sé que estoy fichado, y que esto es lo que

88 For the exact circumstances, see Soldevila Durante (1999: 43).

89 See Ette (2004a: 202sq.).

90 See Aub (2001: 93). 
cuenta, lo que vale" (Aub 2002: 113). Aub leveled the charge that France was still continuous with Vichy and the "archivos de una policía fascista" (Aub 2002: 115). It was high time that the country came to grips with its past and distanced itself from the "monstruosa manera de entender policiacamente al mundo" (Aub 2002: 116).

Not only in Franco's Spain but in republican France was Max Aub forced to experience how the old lists survived and retained their coercive power. Consequently, lists were also to be found in his literary grappling with the concentration-camp experience. The writing done in internment was soon followed by a post-internment writing that was clearly under the influence of the univers concentrationnaire and ascribed to it a very special function.

Doubtless one of the most fascinating twentieth-century literary depictions of life and survival in the concentration camp is Aub's Manuscrito Cuervo: Historia de Jacobo, a "frictional" tale ${ }^{91}$ told from the perspective of the raven Jacobo. In 1952, a year after his open letter to the French president, Manuscrito Cuervo appeared in Aub's own periodical Sala de espera and then was published in its final form in $1955 .{ }^{92}$

Without going into the highly complex (and list-riddled) structure of this "raven manuscript", it should be emphasized to what degree this raven's report on the world of the concentration camp quite consciously employs imagery from the universe of the "concentrationists". ${ }^{93}$ For in a highly concentrated way, human destinies flare up briefly before they vanish into the darkness of the (hi)story. Accordingly, in the chapter "Algunos hombres," some of the concentrationists reemerge from the anonymity to which they were consigned by the nameless terror of persecution and destruction in the era of twentieth-century totalitarianism.

Right from the beginning of the chapter, the raven Jacobo notes that there are some six thousand internees in the camp, most of whom do not know why they are being held prisoner (Aub 1999: 154). ${ }^{94}$ Thereupon the raven narrator proceeds to choose at random certain

91 For the term “friction”, see Ette (1998: 308-312).

92 The following citations are from the critical edition of Aub (1999).

93 Aub (1999: 96): “Concentración, es decir: Lo más aquilatado, la médula, lo más enjundioso".

94 The guards are as ignorant of the reasons as are the internees. 
index cards documenting internees of the concentration camp in southern France during June 1940 - a ploy not untypical of Aub, whose characters tend to suddenly pop up and then disappear just as quickly. In a telegram-style prose, the author brings to light a handful of lives and the singular ways in which they were disrupted. The arbitrary ascriptions of identity, but also the "travel movements", make very clear how the dialectic of Enlightenment with its totalitarianism simultaneously unfolds a dialectic of homelessness that is no more strongly focused than in the concentration camp. Here are just a few excerpts from Jacobo's list, which in turn refers to other lists:

Julien Altmann, relojero, treinta y cinco años, francés, después de haber sido alemán. Estatura regular, poco pelo, nariz larga, traje raído, ojos enrojecidos (Aub 1999: 154).

Jerzy Karpaty, Zapatero, húngaro. Pequeño, gordo, pero ya no tanto; con las piernas arqueadas. Sin complicaciones. Judío. Parlanchín. Tampoco sabe por qué está aquí, aunque supone que la policía halló su apellido en la lista de una Amicale de internacionales húngaros (Aub 1999: 155).

Ludwig Schumacher, químico, ingeniero químico, alemán. Joven, alto, fuerte. Refugiado en Francia desde 1933. Con todos sus papeles en regla, alistado en la Legión Extranjera, en trance de revisión médica (Aub 1999: 156).

Gonzalo Rivera Torres, español, cetrino, nariz corvina, pelo corvino, uñas corvinas. Mecánico. De los pocos que no protestan. Comunista. Se pasa el tiempo cantando. Su única preocupación: conseguir una guitarra. A los dos días de llegar a París, salido de un campo de concentración del sur de Francia, le volvieron a agarrar. Está de vuelta (Aub 1999: 156sq.).

Jan Wisniack, checo, mal encarado, tuerto, sin oficio ni beneficio conocido, hombre de malas pulgas. Setenta y dos años. Andaba por el mundo, para verlo - según dice (Aub 1999: 157).

Franz Gutmann, dícese luxemburgués; peletero. Denunciado por su mujer como alemán. El no le quería conceder el divorcio, a pesar de los cuernos (Aub 1999: 158).

Paul Marchand, pintor, belga, a lo que él dice: amigo personal del rey Leopoldo III. Alto, gordo. La amistad que pregona no le favorece con las autoridades, que tildan, actualmente, al soberano belga de traidor (Aub 1999: 159).

Héctor y Francisco Girardini italianos, hermanos gemelos, gordos, bajos, con barba, frente despejada, gafas, un poco al estilo de los enanos de Blanca Nieves, los detuvieron a los dos porque no sabían a ciencia cierta quién era el sospechoso. Dicen que uno es anarquista. Ellos no dicen cuál (Aub 1999: 166). 
The cunning of this list consists in the fact that not only the absurdity and caprice of totalitarian rule but also the open-ended nature of the list is presented the reader, who himself could also conceivably be catalogued in a movement that - in consideration of the individual lives of those interned - unfolds in a highly varied and irregular manner; yet still, on the whole, in a linear direction. It is the movement of a story that sweeps everything along with it irrespective of the native land and goals in life of the various camp detainees in this catalogue of lives. The emergent movement and perspective is comparable to that of Benjamin's Angel of History, which in its backward-sweeping movement sees rubble being heaped at his feet: destroyed lives caught up in the vortex of a history whose dialectic knows only the homeland of Entronnensein. Like the Angel of History, the writer has no time to wake the dead and piece together that which has been destroyed (Benjamin 1980a: 697sq.). For the writer, too, the barely achieved Entronnensein is the sole homeland that is still conceivable in a world that has in large part become one big concentration camp. Is this not the real answer to the question as to what remains of the totalitarianism, wars, persecution and collaboration of the twentieth century?

\subsection{Cécile Wajsbrot, or the Post-figuration of the Concentration Camp}

In her 1999 essay Pour la littérature, Cécile Wajsbrot (*1954) draws attention in no uncertain manner to that great watershed in the twentieth century which was of major significance for French literature but which for a very long time was blithely passed over by the French:

Entre Balzac, Flaubert, le Breton du Premier Manifeste et Robbe-Grillet, il y a un abîme, il y a 1939-1945, l'horreur du nazisme, la première bombe atomique, l'extermination systématique des Juifs d'Europe et le silence autour; l'Occupation en France, Vichy, la collaboration, et puis l'épuration, notamment dans le milieu littéraire et artistique, ce qu'elle a permis de dire et ce qu'elle a permis de taire, ceux qui ont payé et ceux qui ont continué, comme avant, comme si de rien n'était (Wajsbrot 1999: 23).

Despite the distance in time and variant perspectives, the accord this finds with Max Aub's attestation of 1951 is remarkable: throughout the 1950s, 1960s and 1970s and even to the present day, France and its intellectuals have mostly refused to face the fact that "la société 
française des années cinquante, soixante, et soixante-dix - et on pourrait continuer jusqu'à aujourd'hui - a choisi de fermer les yeux, et de tourner la page, pour passer à autre chose" (Wajisbrot 1999: 23). In contrast to the literature of other countries such as Germany or Russia - where not only did contemporary witnesses come to grips with this period but also those who were born "dans l'ombre portée du souvenir" - French literature has studiously glossed over the fact that our epoch had its genesis in the Second World War and that everything including the "monuments aux morts" - but of course not including the literature - reminds us of this truth (Wajsbrot 1999: 25). In French literature the inquiry has just begun: "Notre scène originelle, c'est Vichy, et comme toute scène originelle, elle gît dans la pénombre d'un inconscient qui ne demande qu'à l'oublier" (Wajsbrot 1999: 27). But in every traumatic ur-scene - says Cécile Wajsbrot in a diction peppered with psycho-analytic jargon - a repression mechanism is at work, a "refoulement" that continues to have reverberations in the sphere of literary theory (Wajsbrot 1999: 27).

In 1990, in his important book on the collective coming-to-terms of France with the German occupation and with French collaboration during the Second World War, Henry Rousso spoke of the trauma of Vichy and the Vichy "syndrome". ${ }^{95}$ In her own study, Silke SeglerMeßner notes that it was "only decades after more than seventy thousand Jewish compatriots had expired in concentration camps, that they were officially mourned” (Segler-Meßner 2003: 53). ${ }^{96}$ And Geoffrey Hartman's study interprets this psychological repression as a kind of collective self-defense mechanism that fifty years post-facto was still in evidence, and with many French Jews still today being subject to a similar mechanism (Segler-Meßner 2003: 53). It certainly remains a question as to what degree such mechanisms of psychological repression can be integrated into the deplorably homogeneous image of a "Europe without Jews" ${ }^{, 77}$ - and not only with respect to the French

95 See Rousso (1990).

96 "um die über 70.000 jüdischen Mitbürger, die in den Konzentrationslagern ums Leben kamen, hat man erst Jahrzehnte später offiziell getrauert”.

97 Approaching the matter from a completely different perspective, Bernard Wasserstein invoked the specter of a "Europe without Jews" in a period that was witnessing a Vanishing Diaspora - the title of his 1996 book, with the subtitle "The Jews in Europe since 1945". In this work he puts forward the thesis that perhaps the most important repercussion of the Holocaust was that postwar Jewish life 
situation. In this regard Cécile Wajsbrot makes her position quite clear, being in favor of a literature that must meet the challenge of careful inquiry into the emergence of National Socialism and the inhuman consequences of totalitarianism contained within the sphere of literature itself.

In her plea for literature, the French author emphasizes that in the final analysis it is only the work that counts - "L'œuvre est ce qui compte" (Wajsbrot 1999: 58) - since the "raison d'être des écrivains" as well as the "raison d'être de la littérature" lies in the inimitable "vision du monde" that is elaborated within a specific literature (Wajsbrot 1999: 59). But it seems to me that such a view demands from literature - and for literature - the aesthetic shaping of a lifeknowledge that in its multi-dimensionality and polysemy develops a vital and socially responsible relationship to the various aspects of life and survival. ${ }^{98}$

Of critical importance to Wajsbrot - who for several years now has been dividing her time between Paris and Berlin - is the preoccupation with that historical period which, as portrayed in our discussion, would be the point of departure and reference for a tradition that should be regarded as essential to the worldwide development of literature without a fixed abode. For even in terms of the very concepts of exile and diaspora, what developed out of two World Wars and the persecution and murder of the Jews at mid-century has left its stamp on the literature and philologies that have emerged in strengthened form since the beginning of the twenty-first century and the concomitant fourth phase of accelerated globalization. Without due consideration of the Shoah, it is as little imaginable that we can gain an adequate understanding of literature without a fixed abode as it is that we should reduce such literature to this sole perspective and tradition.

In view of her poetics of literary works, it only made sense in Cécile Wajsbrot's search for answers to the question "What of Auschwitz remains?" that she should not limit herself to the essay but would

has been characterized by an obsession with survival. Beyond the borders of Israel, and particularly in the open societies of the West, the strong pressure to assimilate has greatly diminished the chances that there will be any collective survival of the Jews (see Wasserstein 1999: 327sq.).

98 Wajsbrot (1999: 49): “Quelque chose, la déportation, l'exil, la guerre, la catastrophe. Et quelqu’un l’a vécu et survécu”. 
make resort to other narrative and representational forms. Appearing in 2004 at the same time as her novel Le Tour du lac (Wajsbrot 2004), was her slim volume Beaune-la-Rolande. From the very first paragraph of the first section (of five) of Beaune-la-Rolande, the narrator leaves no doubt that the ensuing treatment of the theme of concentration camps and Jewish persecution in France will present a wide array of peripatetic figures and will be informed by both linear and cyclical notions of time:

Le vide de la route prolonge le silence des rues, le dimanche est le pire des jours et ce dimanche, le pire des dimanches, l'autoroute ChartresOrléans est devenue Nantes-Bordeaux mais c'est bien tout ce qui a changé, et les années défilent comme les kilomètres, une à une, fastidieuses, et le printemps varie sans ombre, s'étirant vers l'été, s'attardant en hiver, on quitte l'autoroute puis la route s'étend, droite, coupant un paysage monotone, plat, impitoyablement horizontal (Wajsbrot 2004a: 7).

The pitiless advance of time, whose implacability is yet further augmented by the interspliced cycles of weeks, years and seasons, corresponds to the no less inexorable horizontality of a topography without any point of reference in the third dimension. The landscape becomes a landscape of transit, a place of passage that takes one along the highway among the rest of the traffic to a better place. And yet within this landscape of transit, unrolling along the highway, as it were, another transit can be sensed, a transit that heads into the past, a transit camp that was "utilized" for refugees of the Spanish Civil War: Beaune-la-Rolande. This place suddenly takes the place of everything: "rien n'existe d'autre que la mémoire, le souvenir, la commémoration” (Wajsbrot 2004b: 8). Is Beaune-la-Rolande - as one might assume from the annual official discourse - hence nothing more than a lieu de mémoire?

In the hopelessness of her "sur la route" existence (Wajsbrot 2004b: 8), the first-person narrator is simultaneously trapped and complicit in a genealogy that links her with her grandmother. Although she has lost her voice ("la voix"), she sets out on her journey ("sa voie" [Wajsbrot 2004b: 12]), a journey through the "shadows of memory”, as it reads in Pour la littérature (Wajsbrot 1999: 25). This journey is painful at both the individual and collective level, and in Beaune-la-Rolande it leads to the narrator doubting (and despairing) whether in France, "dans ce pays", there exists anything approaching a 
"mémoire collective" that goes beyond the commemorative plaques (Wajsbrot 2004b: 53).

The imaginary "Voilà" (Wajsbrot 2004b: 8) - perhaps never even uttered by her grandmother - reveals to the first-person narrator her obligation to have a closer look at that phenomenon from which most others have averted their gaze (Wajsbrot 1999: 23), but above all to follow the grandmother's voice and her journey as well as the journey of the grandfather she never knew, a grandfather who under the Vichy regime was taken into custody by a simple billet vert and subsequently transported, interned, deported and killed. The search begins, but soon ignorance and helplessness infiltrate the text: "De mon grand-père, je ne sais rien, seulement qu'il est mort à Auschwitz" (Wajsbrot 2004b: 14). The work of memory can no longer reconstruct, but simply construct in an ambiguous fashion those words employed by the anonymous loudspeaker voice to inform the women waiting out front of the barracks of the arrest of their menfolk: "Que disaient-ils exactement, ils vont partir, on les emmène, ils vont travailler dans un camp, ils sont momentanément détenus, retenus, transportés, déportés, concentrés, quels mots employèrent-ils?” (Wajsbrot 2004b: 10). Literature captures all these virtual and simultaneously real voices ${ }^{99}$ and weaves them together in a way that ensnares history and allows the literary text to form. Thus commences a long and never-ending trip ("début d'un long voyage" [Wajsbrot 2004b: 10]) for the narrator.

The fact that the narrative voice is merged with authorial biography lends greater complexity to what from the beginning is a recognizable intermeshing of various time frames (of the May days of the year 1941 and more than half a century of May-days every year after that) and travel movements. This entry in the Journal of the book is dated Paris, 12 September 1990:

Je suis née en 1954 - la guerre était finie depuis neuf ans. Le mari de ma grand-mère est mort, déporté à Auschwitz. Avant d'arriver là-bas, il avait passé un an dans le camp de Beaune-la-Rolande, qui se trouve près de $\mathrm{Pi}$ thiviers. Je n'ai pas connu ce grand-père mais ma grand-mère m'a raconté abondamment, et sans doute très tôt, les chambres à gaz, les camps,

99 One can only make note here of the importance of these voices; see the successful acoustic staging of an initial draft of this text in a radio play by France Culture (“Atelier de Création Radiophonique”), which was broadcast in July 2003 under the title Beaune-la-Rolande: La Cérémonie. I would like to thank Cécile Wajsbrot for providing me with a recording of it. 
l'arrestation, la police venue la chercher avec ses deux enfants, le passage de la ligne de démarcation, tout, et je porte ces images d'un autre temps, d'une autre vie, sans pouvoir m'en débarrasser (Wajsbrot 2004b: 15sq.).

The specification of time and space enfolds the narrator in the tale she is telling, yet still without the narrator being equated with the "real" author external to the text, even if the book's jacket blurb does speak of the "grand-père de l'auteur" (Wajsbrot 2004b: jacket blurb) and in an allusion to the author's own name there is mention of the fact that in Poland no one requires an explanation as to how to pronounce the name of the unnamed narrator in the story (Wajsbrot 2004b: 42). The "frictionalization" of the narrative voice - produced through the oscillation between fiction and diction - turns this voice into a bearer of life-knowledge that is introduced as knowledge about a life whose existence can no longer be directly testified to but only through reference to the grandmother: "une vie qui n'est pas la mienne mais dont l'ombre varie avec les heures" (Wajsbrot 2004b: 16). With the means at its disposal, literature attempts to establish this shadowy realm beyond official days of remembrance.

But soon, owing to topographical and climatic conditions that are introduced, the death camp Auschwitz is superimposed on the concentration camp Beaune-la-Rolande: "une portion d'Europe centrale transplantée à cent kilomètres de Paris” (Wajsbrot 2004b: 21). Auschwitz is everywhere and nowhere: "Auschwitz ne se trouve pas en Pologne, c'est un lieu indéfinissable qui est partout et nulle part" (Wajsbrot 2004b: 55). In this literary treatment the lieu de mémoire is no longer to be localized but has multiplied, is ubiquitous. Everything is set in motion and evades static assignment.

So it is hardly surprising that the narrator feels a greater affinity not to settled persons ("sédentaires") but to those who have been deported, who are refugees, the migrants - "ceux qu'on appelle les sanspapiers" (Wajsbrot 2004b: 20). The deportation of the unknown grandfather; the annual journey of grandmother and granddaughter to the concentration camp of Beaune-la-Rolande; the trip of the granddaughter and the narrator to Auschwitz as well as Cracow, Warsaw and Vilnius; the deportations, forced migrations and voluntary journeys - all these combine with restless, erratic and peripatetic figures to produce (if one will pardon the phrase) a kind of littérature sans- 
papiers. It is no accident that the preparations of the suffering narrator for her visit to Auschwitz (in the Journal entry dated Cracow, 7 May 1990) are linked to a conversation with the Polish poet Baranczak, who immigrated to the United States in 1981 and has now returned to Poland for the first time. The prefiguration of the concentration camp that has the ten-year-old boy ${ }^{100}$ in Albert Cohen's Marseilles experiencing a concentration camp en miniature is linked through the postfiguration of the camp with the fate of migrants on the cusp of the twenty-first century: "tous les réfugiés, à Sangatte ou ailleurs, et tous ceux qu'on refuse, tous les Kurdes débarqués à Fréjus, les Polonais qu'on emprisonne parce qu'un feu s'est déclaré dans une chambre étroite" (Wajsbrot 2004b: 31sq.). The list of the nation-state's exclusionary mechanisms is long.

Here the inherited model of movement from the Shoah literature is conjoined with the vectorial imagination of a literature nourished by the mutual overlay of migratory processes. In its post-figuration, the concentration camp becomes a focal point for worldwide movements that intersect and overlap in time and space. Thus does the univers concentrationnaire become a bio-political as well as literary paradigm of a writing that knows well the dialectic of homelessness: swept away like Walter Benjamin's Angelus Novus, who cannot and will never close his eyes.

But that is precisely the task of literature - and the task of philology. In this text criss-crossed with migrations, we follow the angel of a history that traces a movement between the Polish town of Kielce (which the grandfather left because of the pogroms) and Paris, Beaune-la-Rolande, Compiègne and Auschwitz, but also between Paris, Berlin-Wannsee, Warsaw and Vilnius - a movement which connects itself up with the vectors of other deportations and migrations without ever being able to dissolve itself in later streams of refugees.

Out of the survival of the concentration camp into the present day and out of the concomitant phenomenon of a homeland characterized

100 The mother of the narrator in Beaune-la-Rolande is also ten years old when the French police try to arrest her along with her brother and mother; but as if by some miracle, these remaining members of the family are spared, and the family genealogy - and thus that of the narrator - remains intact (Wajsbrot 2004b: 31sq.). 
by precarious and tentative Entronnensein has emerged a literature without a fixed abode, a literature which one can neither label a national literature nor world literature, however one wishes to define the terms. This littérature sans domicile fixe - whose imagination is predominantly vectorial in nature - long ago established itself in the gray zone between a national and a global literature. In an unobtrusive manner, Beaune-la-Rolande - which is always jumping back and forth between France, Germany and Poland - evades the seemingly selfevident national paradigm. And thus do not only the author's travels, but also the movements of her writing link France with Germany and Poland in a way that connects the literatures of these countries with one another in a period characterized by a dialectic of homelessness. For amidst the silence of the Sunday streets, which marks the beginning and end of Beaune-la-Rolande, a literature that has overcome its settledness has also succeeded in establishing a homeland in Entronnensein that - in Erich Auerbach's sense - lies beyond the nation. The Shoah literature finds its way into the literature without a fixed abode, whose strength is not attested to and generated by a certain place but through a movement, through the literature itself - in search of the places and movements of the human being in the universe.

\section{Bibliography}

Agamben, Giorgio (2003a): Homo sacer: Die souveräne Macht und das nackte Leben. Translated from the Italian by Hubert Thüring. Frankfurt/Main: Suhrkamp.

- (2003b): Stato die eccezione: Homo sacer, II, 1. Torino: Bollati Boringhieri.

- (2003c): Was von Auschwitz bleibt: Das Archiv und der Zeuge (Homo sacer III). Translated from the Italian by Stefan Monhardt. Frankfurt/Main: Suhrkamp.

Albert, Matthias (2002): Zur Politik der Weltgesellschaft: Identität und Recht im Kontext internationaler Vergesellschaftung. Weilerswist: Velbrück Wissenschaft.

Arendt, Hannah (1991): Elemente und Ursprünge totaler Herrschaft. Complete edition. Munich/Zurich: Piper.

Aub, Max (1999): Manuscrito Cuervo: Historia de Jacobo. Introducción, edición y notas de José Antonio Pérez Bowie con un Epílogo de José María NaharroCalderón. Segorbe/Alcalá de Henares: Fundación Max Aub/Universidad de Alcalá de Henares.

- (2001): "Diario de Djelfa”. In: Obras completas, vol. 1: Obra poética completa, Dirección de la edición Joan Oleza Simó. Edición crítica, estudio introductorio y notas Arcadio López Casanova [among others]. Valencia: Biblioteca Valenciana. 
- (2002): “Carta al Presidente Vicente Auriol”. In: Hablo como hombre. Edición, introducción y notas de Gonzalo Sobejano. Segorbe: Fundación Max Aub.

Auerbach, Erich (1967): "Philologie der Weltliteratur”. In: Gesammelte Aufsätze zur romanischen Philologie, edited by Fritz Schalk and Gustav Konrad. Bern/Munich: Francke, pp. 301-310 (first published in Muschg, Walter/Staiger, Emil (1952) (eds.): Weltliteratur. Festgabe für Fritz Strich. Bern: Francke, pp. 39-50).

- (1969): "Philology and Weltliteratur". Translated by Maire and Edward Said. In: The Centennial Review XIII, pp. 1-17.

- (1982): Mimesis: Dargestellte Wirklichkeit in der abendländischen Literatur. Bern/Munich: Francke Verlag.

Auerbach-Alphabet: Karlheinz (Carlo) Barck zum 70. Geburtstag (2004): Special issue of Trajekte V, 9.

Bade, Klaus (2000): Europa in Bewegung: Migration vom späten 18. Jahrhundert bis zur Gegenwart. Munich: C. H. Beck.

Benjamin, Walter (1980a): “Über den Begriff der Geschichte”. In: Gesammelte Schriften. Vols. 1 and 2, edited by Rolf Tiedemann and Hermann Schweppenhäuser. Frankfurt/Main: Suhrkamp, pp. 691-704.

- (1980b): "Die Aufgabe des Übersetzers”. In: Gesammelte Schriften. Vol. IV, 1, edited by Rolf Tiedemann and Hermann Schweppenhäuser. Frankfurt/Main: Suhrkamp, pp. 9-21.

Blumenberg, Hans (1979): Arbeit am Mythos. Frankfurt/Main: Suhrkamp.

Casanova, Pascale (1999): La République mondiale des lettres. Paris: Seuil.

Cohen, Albert (1945a): “Jour de mes dix ans”. In: La France libre (16 July), pp. 193200.

- (1945b): “Jour de mes dix ans”. In: La France libre (15 August), pp. 287-294.

Cramer, Friedrich (1996): Chaos und Ordnung: Die komplexe Struktur des Lebendigen. Frankfurt a.M./Leipzig: Insel Verlag.

Djebar, Assia (1998): "Schreiben in Europa: Über den Roman Nächte in Straßburg.” Lecture at the "Haus der Kulturen der Welt", Berlin, 28 November 1998. In: $<$ http://www.unionsverlag.com/info/link.asp?link_id=256\&pers_id=12\&pic=../ portrait/DjebarAssia.jpg\&tit=Assia\%20Djebar $>$.

Eckermann, Johann Peter (1981): Gespräche mit Goethe in den letzten Jahren seines Lebens. Vol. 1, edited by Fritz Bergemann. Frankfurt/Main: Insel Verlag.

Ette, Ottmar (1998): Roland Barthes: Eine intellektuelle Biographie. Frankfurt/Main: Suhrkamp.

- (1999): “Albert Cohen - 'Jour de mes dix ans': Räume und Bewegungen interkultureller Begegnung”. In: Große, Sybille/Schönberger, Axel (eds.): Dulce et decorum est philologiam colere: Festschrift für Dietrich Briesemeister zu seinem 65. Geburtstag. Vol. 2, Frankfurt/Main: Domus Editoria Europaea, pp. 1295-322.

- (2001): "Europa als Bewegung: Zur literarischen Konstruktion eines Faszinosum”. In: Holtmann, Dieter/Riemer, Peter (eds.): Europa: Einheit und Vielfalt Eine interdisziplinäre Betrachtung. Münster/Hamburg/Berlin/London: LIT Verlag, pp. 15-44. 
- (2002): Weltbewußtsein: Alexander von Humboldt und das unvollendete Projekt einer anderen Moderne. Weilerswist: Velbrück Wissenschaft.

- (2004a): ÜberLebenswissen. Die Aufgabe der Philologie. Berlin: Kulturverlag Kadmos.

- (2004b): "Wege des Wissens: Fünf Thesen zum Weltbewusstsein und den Literaturen der Welt”. In: Hofmann, Sabine/Wehrheim, Monika (eds.): Lateinamerika: Orte und Ordnungen des Wissens. Festschrift für Birgit Scharlau. Tübingen: Gunter Narr, pp. 169-184.

Finkielkraut, Alain (1980): Le Juif imaginaire. Paris: Seuil.

Fraser, Nancy (1997): Justice Interruptus: Critical Reflections on the "Postsocialist" Condition. New York: Routledge.

Frenzel, Elisabeth (1983): Stoffe der Weltliteratur: Ein Lexikon dichtungsgeschichtlicher Längsschnitte. Sixth edition and with an added index. Stuttgart: Alfred Kröner.

Goytisolo, Juan (1994): “On Emine Sevgi Özdamar”. In: New York Times Literary Supplement (2 December), p. 12.

Habermas, Jürgen (1986): “Nachwort”. In: Horkheimer, Max/Adorno, Theodor W.: Dialektik der Aufklärung: Philosophische Fragmente. Frankfurt/Main: S. Fischer, pp. 277-294.

Höffe, Otfried von (1999): Demokratie im Zeitalter der Globalisierung. Munich: Beck.

Horkheimer, Max/Adorno, Theodor W. (1986): Dialektik der Aufklärung: Philosophische Fragmente. Frankfurt/Main: S. Fischer.

Huntington, Samuel P. (1996): The Clash of Civilizations. New York: Simon \& Schuster.

Kann, Emma (1986): “Biographische Notizen”. In: Exil VI, 1, pp. 66-77.

- (1998a): “Der Vagabund”. In: Mnemosyne 24, p. 15.

- (1998b): “Auf dem Meer I”. In: Mnemosyne 24, p. 18.

Meyer-Kalkus, Reinhard (unpublished paper): "Weltliteratur über Goethe hinaus”.

Michaux, Henri (1956): “Lieux lointains”. In: Mercure de France 1109, p. 52.

Nietzsche, Friedrich (1988): Die fröhliche Wissenschaft ("La Gaia Scienza”). In: Sämtliche Werke: Kritische Studienausgabe in 15 Einzelbänden. Edited by Giorgio Colli and Mazzino Montinari. Vol. 3, Munich/Berlin: Deutscher Taschenbuch Verlag/Walter de Gruyter.

Özdamar, Emine Sevgi (2004): "Wir wohnen in einer weiten Hölle (interviewed by Nils Minkmar)”. In: Frankfurter Allgemeine Sonntagszeitung 47, p. 23.

Rousso, Henry (1990): Le syndrome de Vichy: De 1944 à nos jours. Paris: Seuil.

Segler-Meßner, Silke (2003): Literatur und Zeugenschaft. Zu Darstellung und Interpretation der Shoah in Frankreich. Stuttgart: University of Stuttgart (unpublished postdoctoral thesis).

Singer, Wolf (2003): Ein neues Menschenbild? Gespräche über Hirnforschung. Frankfurt/Main: Suhrkamp. 
Soldevila Durante, Ignacio (1999): El compromiso de la imaginación: Vida y obra de Max Aub. Segorbe: Fundación Max Aub.

Valbert, Gérard (1990): Albert Cohen, le seigneur. Paris: Grasset.

Wajsbrot, Cécile (1999): Pour la littérature. Paris: Zulma.

- (2004a): Le Tour du lac. Paris: Zulma.

- (2004b): Beaune-la-Rolande. Paris: Zulma.

Wasserstein, Bernard (1999): Europa ohne Juden: Das europäische Judentum seit 1945. Translated from English by Bernd Rullkötter. Cologne: Kiepenheuer \& Witsch.

Young-Bruehl, Elisabeth (2000): Hannah Arendt: Leben, Werk und Zeit. Translated from English by Hans Günter Holl. Frankfurt/Main: Fischer Taschenbuch Verlag. 
Susana Romano Sued

\section{The Castilian Language, a Mosaic of Languages: An Exercise of the Memory as a Genealogy and Archeology of Culture}

\section{The mosaic}

Cultures resemble mosaics and can also be compared to palimpsests. Old manuscripts which bear the traces of former writings, scriptures that have been erased in order to be able to write upon them and that now display a new text, are called palimpsests. In painting, the process of overwriting, of correcting anterior brushstrokes is called pentimento. This is the name of the technique because the painter repents, that is, wishes to change a detail and applies another touch. This can be revealed by probing the canvas and revealing hidden brushstrokes and colors. I think that these designations, pentimento, palimpsest or mosaic are also adequate names for describing language. Using these concepts, we can meditate on language. And this also explains how I chose the title of the present meditation: The Castilian language, a mosaic of languages.

According to the dictionary a mosaic is the artistic work resulting from a combination of differently colored pieces of stone, glass, ceramics, arranged to form figures. In the combined pieces of cultures, crystallized into languages, contributions of individual communities and their tongues are continuously inscribed, contributions that have developed in the co-existence and exchange of various historical epochs and of multiple geographic settings. And these pieces add up like superimposed and interconnected layers, like soils worked over again and again, and sometimes they are hidden away in shame and can only be perceived in the telltale signs of fraud or coercion.

\section{Meditations on memory}

Memory is a faculty and a treasure. The collective upholding of memory hears the voices of the generations and writes them down on walls 
and tablets, in codices and pieces of papyrus. Individual reminiscence relies on memory, on images that enter through the eyes, through the ears and that return when evoked: feeling the needle's mark on etchings, the rifts on the surface of the petroglyph.

The memory, at the same time the register and chest containing the origins and epochs of mankind, takes on - for some cultures - the phantasmic form of the Absolute Book.

In Psalm 139, which tells us about divine omniscience, we also hear of the book. The Book is the memory of God, the fundamental instrument for the Creator as Lord and Judge. It is here that the decisions about what is to be and what is not, what must be crossed out and what must remain, are inscribed. The completeness and closure of the text oppose the incompleteness and continued openness of the human interpretation of it. If the infinite dimension of the text is based on the open-endedness of possible readings, then the infinite dimension of memory is based on its mutability.

\section{The Book. Borges}

In numerous short stories and essays, Borges meditated on and wrote about the Library and the Book as metaphors for human memory. So we hear of a book of sand. This book is different from all other books because it is impossible to skip through it backwards and go back to the first page. Before getting to this first page, other pages impose themselves, pages that can't be retraced later on and disappear forever. The book rewrites itself again and again for the reader who - by chance - happens to be turning the pages. It is precisely this combination of diverse scriptures and readings that represents destiny as memory.

On the other hand, the palimpsest is the book that like the book of sand lacks a firm and definitive shape; it's a book set in motion. Thomas de Quincey, one of Borges' favorite authors, described exactly the technique by which the parchment can be made to carry different inscriptions successively. What in most remote antiquity had been a Greek tragedy could, in late antiquity, by way of careful preparations, be cleaned in order to capture and include an allegorical legend; and in the Middle Ages it could incorporate an epos of chivalry. The chem- 
istry and philology of the time were capable of changing the direction of oblivion, now moving into the future, not backwards into the past.

So this is how the preservation of memory is linked to inscription, to mnemonic conservation which is, in turn, part of the world of the written letter. This world consists of traces upon traces, characters upon characters that the individual memory blends into a matrix, a place for continuous writing and rewriting of reminiscences.

Collective memory, like in a constantly recreated mirror, writes and recognizes itself in the memories of the beginning, of the cosmogonies. Here humanity is building backwards, moving towards the myth on a long road home, beyond the Phoenix (who - in even deeper strata - is resting on his own ashes) and towards his ancestors. This is the magic art of the philologer who turns chronological orders around and reads backwards in time: he or she turns the pages and finds the waystations of the itinerary through history.

The restitution, then, of what has been forgotten is the process of reading the written text: layer by layer one scripture attaches and copies itself onto another one, creating the enigmatic palimpsest of the human spirit as the dramatic testimony of the struggle between time and eternity.

The primordial scene towards which human memory orients itself is, for one cultural sphere, the pact that God sealed with the people of Israel. In the book of Deuteronomy the recollection of the first moment of liberation of the pact is the central motif along with the main imperative: recollection must mean loyalty, obedience and life; oblivion implies defeat, the return to Egypt and death. Memory and oblivion are eschatological antagonists in the drama of salvation.

Fables, stories of miracles and folklore are more manifestations of the world of memory in which oblivion is equated to death and exile, whilst recollection means salvation and the return home. Ever since the Odyssey up to today, the adventure of remembering is like a voyage to a submerged world - a voyage all epic heroes must undertake. Later on, memory opens up to Tradition, that is to say, preservation by inheritance and legacy. And this is where memory and tradition part and, drifting ever further apart, give rise to two new attitudes in the face of the past: on the one hand, the experience of being part of history, History turning away from man and leaving him alone in the solitude of time. On the other hand, the individual turns towards the 
past, starts taking part in it and appropriates it by using his intuition and imagination. Even though the past is dead - or asleep -, genius and ingenuity, the creative spirit can awaken it, turn it back into life and restore it for the present. This is how the philologer, like the archeologist, probes into times gone by on the pages of human memory and reconstructs the past.

The ars memoriae of literary tradition therefore bears testimony to the difficulties and detours that memory-work has to go through when it is confronted with the fight for or against oblivion between the guardians of the ruins and the tamers of evocation.

The eternity of human creations interposes itself in time, up against the irredeemable finitude of a lifetime. Word and song are the consolation that accompanies man in the projection of his tradition into the future, his legacy to posterity. And this is why we see the moments of the evolution of a language in the texts of a given cultural sphere. Castilian spans over many cultural treasures, social, idiomatic and lexical imaginaries. What then does our language remember, and what does it forget of its vicissitudes and transgressions?

The daughter of multiplicity, the Castilian language rose from the agonizing dissemination of Medieval Latin, which fragmented and morphed into Romance languages, a Babel of new languages in this emerging Europe, fragmented like a mosaic of nations.

Up until the reign of king Alfonso X, Castilian as one of Latin's daughters still had to be considered Romance, a language full of imprecision and hesitation, always changing along with the loanwords from other languages. Alfonso X, king of Castile and León from 1252 to 1284, had a decisive influence on the usage of Castilian by declaring it the official language of Castile and creating an orthographic system that put an end to difficulties concerning the written representation of sounds. Thus Alfonso installed himself as the creator of Romance Castilian prose.

From that moment on, the complementary action of diffusion and reception of Castilian, peaceful or violent, prosperous or unfortunate, hasn't ceased and shows no signs of doing so today.

Let's not forget that the first examples of literature in Romance we have today are the so-called jarcias: these are short lyrical chants that consist of two, three or four verses that the poets, writing in Arabic or Hebrew, put at the end of larger poems called moaxahas. They are 
oral lyrics written down in poems by men of letters or Hebrews who used them as a closing note to their moaxahas.

The existence of a very extensive corpus of lyrical poetry indicates a strong oral tradition, poetry we can only access through transcripts elaborated much later. This poetry consists of popular songs - usually about love - that were sung while laboring in the fields or at weddings, fairs and pilgrimages.

Given their Mozarabic character, the jarcias mixed Romance with Arabic words, as in this example:

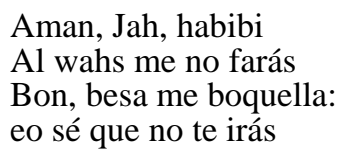

In the case of the Judeo-Spanish romancero, Hebrew words would be sprinkled in.

Quite similar to this orally communicated amorous register, we find the legacy of the coplas, like those of Jorge Manrique, deep reflections on the ephemerality of time and worldy things, on life and death, grounded in memory. Here is an example of what was said above: poetry as the memory of humanity. See the eternal verse of Jorge Manrique in ...

Coplas a la muerte de su padre

Recuerde el alma dormida avive el seso y despierte contemplando

cómo se pasa la vida, cómo se viene la muerte tan callando.

quan presto se va el plazer

cómo después de acordado, da dolor

cómo a nuestro parecer cualquier tiempo pasado fue mejor

After poetry, the epic and other genres such as theater and prose (which would flourish from the books of chivalry on) came to Castilian. The cantares de gesta broke up. The troubadours that carried around with them the heroic deeds of the Cid in songs reduced these, for practical reasons, to a limited number of stanzas, preserving the 
most important details. These texts gave birth to the romances which were passed on only orally.

The Spanish romancero has a long and uninterrupted tradition. The fact that the romanceros were carefully preserved by the Jewish communities when these emigrated from Spain after the expulsion of 1492 goes to show how carefully the past and its distinct registers were preserved in poetry. In this case, poetry written in Castilian, using the Hebrew alphabet, with Hebrew terms blending in as well.

\section{The oral tradition and collective memory}

Traditions are made and remade by telling them. Tucked away in the memory of those telling it, the oral text is brought up to the present by narrating it, usually in front of an audience, so that it may be memorized by a new generation of people bearing the tradition. For different reasons the text is constantly reinvigorated and modified, enriching the latent legacy.

The Spanish language in Latin America, by the way, is part of this culture and influenced by it. Literature as - in the south - an eminent and noble form of language is an obvious and privileged source for reading routes, waystations and origins. In the end, a palimpsest of considerable joy and considerable pain, reaching from the indigenous languages of this land to the foreigners who were covered by the warm blanket of the Castilian language.

The arrival of the Castilian language to America set in motion a process of accelerated blending with indigenous languages by acculturation. It also accelerated the disappearance of many of these languages for lack of a tradition of writing.

As George Steiner notes in After Babel, every year some of those languages that we consider "endangered" disappear. These are languages spoken in isolated or dying communities. Today, whole language-families are between life and death, flickering in the memory of some informants of high age. One could say that almost every instant some rich and vulnerable word or turn of phrase falls into total silence, most of all in the case of the American indigenous languages.

But here they are, texts that are sometimes transcriptions of the oral tradition and sometimes translated transcriptions; and there is, above all, this legacy or infinite treasure that within the language, in 
the house of the Castilian language, takes up quarter in translations. These remind us of a memorable poetic term, the expressions of old traditions and the murmur of some creation from yesteryear. This murmur is carried along also through the infinite passages from one language to another in translation.

\section{Digression on translation}

Translation is one of the fundamental activities necessary to keep this memory alive, an activity whose archives have up until now been books in different languages, a medium that today is being substituted little by little by IT-based memories and digital hardware.

The passages and multiple crossings are a process of temporal, spatial and linguistic deferral that is of a similar relevance concerning translation as a practice, a process and a result in translated literature. This crossing bears the mark of the subject, the subjects. And as in the process of writing, creation emerges from the order of subjectivity and corresponds to the peripeties of the individual letter in its struggle against the laws of language, just like the writing in a translation fluctuates between the dimensions of identity and subjectivity. This is why the analysis and the comparison of the strategies chosen by the writer-translator can give us some hints about how desire takes its course, desire for the letter, for writing.

Literature, poetic texts - and already the Russian formalists taught us this - build their own universe of signification in which connected, conventional signifiers (arbitrary signifiers in Saussure's terms) recede, facilitating a flow of multiple signifiers which rise from all textual levels of signification. The denotative level leaves space for the floating "play" of connotations. The reconstruction of this multiplicity of meaning in the texts is the method and aim of every translation. The universe of connotation, when linked to denotation, creates the complicated and singular order of the poetic text, guiding its meaning.

In the crossing one passes through several stages. And the most important stage, articulating the languages, is the subjectivity of the translator, who is inscribed into his or her cultural background. Translation, when observed from the micro-perspective of a translator's work (an encounter with the text in a foreign language), brings different dimensions into play, creating a tension between them: his cultural 
and literary background knowledge, his knowledge of the institutional world of literature and his relation to it, finally the depth of his subjectivity. It is at this point that interpretation gets going. Translating literature always means translating an interpretation of a literary work. To be more precise: it implies composing an all-inclusive interpretation of a literary work in a second language. One translates not only speech, but also what has been spoken, i.e. the meaning of the text. So the result of this specific process has to be seen as a literary work, and what has been translated into the second language, at least for him who reads it at home in the host-language, serves as a substitute to language, literature and culture. Interpretation takes place in the reconstruction of the original perspective.

The same tension that translation creates between cultures and the languages (and within which it installs itself) is involved in the process itself and can be found in the translator's gestures. Driven by his desire to translate, his desire for language, it founds a text as the consequence of and the answer to his wandering wishes, searching and beating a path between languages, guided by his ardor and his knowledge - which are not always in synch.

The subject, the translator who writes in his mother tongue, is confronted with the abyss beyond this language, confronted with language itself. Haroldo de Campos reminded us of the difference between "language" (lengua) and "speech" (lenguaje) and that in poetry it is imperative that the translation be made in terms of "speech". He said this with regard to Hölderlin's translations of Sophocles, which were subject to most devastating criticism from his contemporaries and are now appreciated in good right for their unique contribution to the enrichment of German poetic language. Walter Benjamin praised these translations emphatically, reacting to those who criticized the supposed failures of the translation, accentuating the creativity of Hölderlin's "mistakes".

We should remind ourselves that Walter Benjamin told us about a pre-Babylonian, angelic language that mankind could have received as a legacy from God. The disaster of Babel, the painful fragmentation was going to be soothed by the healing efforts of the poets, whose poetic universe would supposedly be completely expressed in this language. And translation would therefore recover all of its meanings. 
In the translation's reproductive function, the works are part of tradition. This means that the translator, the interpreter, "the one who speaks in the interstice”, reproduces legitimately and is legitimating his presence on the stage where he seizes the past, turning it into the live present: with a certain authority he takes a careful decision and thus fulfills the role of a connecting piece. On the one hand, the works come to us through history and tradition, talking with their mouths full, accompanied by everything that has been said (interpreted) about them. On the other hand, there is the process of re-reading (interpreting) again for today's audience, and here we have the transmission itself, and then the new words are pronounced, those that the process of interpretation favored.

If we listen closely for the impulse of lyricism, auscultating language, we realize that the smooth flow of poetry depends much more on the impact that foreign texts produce in the host language, a language which makes room for the translator's subjectivity. The translator is auscultating (at the same time) that which is on its way in and what his own language offers in the way of hospitality. I myself take translation to be an event that makes the Diaspora of writing possible, a dissemination and a flowering of meaning thanks to which literature subsists beyond its borders.

This act has been repeated innumerous times since the beginning of writing itself, it has guaranteed the survival of literature thanks to its sending it beyond the shores, beyond the borders of the original languages to diasporic soils, performing time and again the metaphor of the ferryman/translator who transports his precious cargo from one shore to the other. The process that in the German language is denominated so adequately "über-setzen": to transport/to translate. The precious cargo transported here sometimes won't see the light, remains latent and hidden in some corner of culture.

According to the facts established by ethnic history there is a hidden literature dating from ancient times, from before the arrival of Columbus, which tells us about how a collective identity was created, a fact that the practice and know-how of the noble indigenous people bear witness to today. It is this language, a different language, that American Castilian has built itself and its œuvres on, be it under the shroud of silence, or be it in coexistence with more hospitable writing. José María Arguedas, the Andean anthropologist, revealed to the cre- 
oles the existence of utopian and messianic narrations in Quechua and incorporated them into his literary works. Indigenous oral poetry survived oblivion thanks to the explorations of some archeologists that gave us knowledge about the ritual worship to the Inca, cosmogonic words of the Guaraní, Aztecs and Mayas in Chiapas, to name just some of the constellations of oral creation that used to live in our America.

These are words that remind us of the fact that we live in and coexist with our language, that we take possession of it and that it takes possession of us, that it houses us, that we inherit it, a living organism that creates and re-creates itself through poetry. Every poetic expression, as a poetic action, is a reminder of the human species and a legacy to the future.

This language that I have called a palimpsest, a pentimento and a mosaic, Castilian, the community's language, is at the same time identical and different to the language every one of us speaks. The language in which we were named even before we were born, the first we were to hear is the language that molds us and turns us into subjects.

Although this language is determined by the grammar of the social and national language, it nevertheless bears the marks of what the family and our parents have passed on to us. It will be the force of order and guidance, our fate, the road we walk on as unique individuals.

We know that no matter how many times we move from one place to another in the world in a Diaspora (this is what I call a translation), we carry with us the gestures, the voices, distilled from the base of the mother tongue. Lalangue, Lacan called it. It intertwines with the common language and becomes singular and unique once again in the poem, in narration, in the drama. It traverses the genealogies, shows itself in the spoken phrases, and resonates in the echo of the lullabies.

In my case Arabic is the ore; together with Hebrew, it is the natural resource to my hearing, my writing, and it makes a mosaic of Castilian.

The voices of the grandparents, the songs, the names of the food, the whisper of secrets - all of these come back to me time and again and accompany my own voice.

I come from a Jewish family, originally from Syria, from both sides. My mother, born in Damascus, came to Argentina as a very 
young girl; she came on a boat, just like everybody else, and brought with her the aromas, the tastes and the worries. Her language was Arabic intermingled with French, the languages of the better-to-do families in Damascus. Therefore my aunts, my mother's older sisters, had names such as Adèle, Rachèle, Victoire. Sometimes, in Damascus, they were ashamed when somebody heard them speak Arabic. My mother, Sara, was six years old when she came to Argentina and her Castilian had no foreign accent.

My father, son of Syrians, got to know my mother in Argentina. Their respective families knew each other. My father got to know my mother after coming back from a longer stay in Jafo, Palestine. In those days Arabic was the lingua franca. My father's family in Jafo spoke Arabic, thought in Arabic, cooked in Arabic. My father learned to write and read in that language. My father and mother shared the secret of the Arabic language, which they did not teach me, nor did they teach my brothers and sisters. I only learned some words, fragments of songs. And Arab cooking because all the meals prepared in my house, as well as in the homes of my aunts and grandparents, were Arab meals.

When I was a small child we lived in a neighborhood where there were many families from the Middle East, from Syria, from Egypt, from Lebanon. All families did their shopping in the Syrian-Lebanese store. There we supplied ourselves with tahine, with parra leaves, with zatar, with jalva, with fila and with baclawa. Also with cuajo, to prepare the laban and the cardamom for the coffee or the seeds of sesm, of burgol wheat, of baharat. Jewish Arabs and Christian Arabs were all in the same club, the older ones playing cards, and the little ones playing together. My grandparents, my uncles and my parents, all in the textile business, did their wholesale shopping in the stores of the Arabs, buying wherever it seemed right, without discrimination.

When I was very young, my parents used to take me to the concerts of an Arab orchestra from Córdoba, the Azur Chami orchestra. He came from a Syrian family that had first migrated to Chile. Azur Chami's vocation was singing. Azur played the lute, the derbeke, the tambourine. He had put together his orchestra and his repertoire included Argentinean folk songs and popular South American tunes that he translated himself and adapted to Arabic, such as the carnavalito or the cha cha cha. This was Azur Chami's thing, roaming from village 
to village, from city to city with the sounds and the lyrics that populated my childhood. Some of these songs, fragments of them, I learned playfully, just like I learned the diverse ways of dancing and cooking.

Now they all live in my poetry, where I remember and listen, feel the tastes, all in their own Arabic, Hebrew and Semitic names. Voices and tastes that have stuck on to me, in me, precious pieces that form a colorful mosaic.

I have gone to many different places and I have lived in different languages. And the Arabic, like the Hebrew, Portuguese, German, French, Latin language all appear incessantly in verse, in the murmurs.

From Diario de hija:

I

No te devuelve mi voz la gratitud del primer murmullo

alojada la memoria sonora

en mi propio pabellón.

En la caracola del oído no entra mi saludo

no entra la palabra del mundo,

ni la campanada del angelus

ni el adiós

Entran los ruidos de la memoria.

entra solamente el pregón del vendedor de cuajada en el mercado

de Jafo;

moja las comisuras

entra el laberinto.

Entra la arena aventada por las ventanas de los tíos.

Entra el trigo sarraceno,

El triguillo esquirlado de mortero

la mancha bruna ha tenido cría.

II

Asomado a la ventana del cuarto de Jafo,

almacena el pregón que está húmedo y blanco de la cuajada:

¡Aj laban!, ¡Aj laban!. El jarro se hunde en el tacho de leche agria.

Luego se reparte en los tazones de los primos,

sobre las hojas de parra que envuelven el arroz

Todavía no he nacido

I carry this treasure with me, the treasure that turns und returns in my writing, which is memory turned letter and tongue, the word of poetry. Just like in Diario del Habla [...] 
En el umbral de la lengua se alzan las grafías de escritos antiguos; es el hebreo, es el árabe, es el sefaradí de mis mayores, admonición sobre la palabra y sobre los treinta y seis justos que sostienen el mundo. El hebreo emparentado, mezclado a los dialectos de la aldea, lejos de la lengua de los asesinos.

Residuos, ruinas, vestigios; el corte en la garganta para la prosodia desconocida. No me muerde aún el idioma. Apenas ha hundido sus colmillos en el corazón de lo gregario; la comunidad, deshecha y esparcida por las diásporas, me confina en lo callado.

Gutural, materna, la lengua de oriente rumia en la duna y en la alta barda costea los restos de coral, y sangra.

Carga los hijos en la espalda; no habla.

Las rimas gorjean en la melodía del destierro mientras las voces desentonan aquí y allá; son las afonías de la despedida, son las endechas mudas, espigando la orilla del corazón biendicho. De noche, los tártaros abandonan el desierto; merodean al borde del sueño, sacan provecho del cansancio y dejan prefijos encajados entre las palabras graves, en las arcadas. Hoy he cedido a la entonación, a la rima pobre, a la desinencia. A la cancelación sonora de la procedencia. Me nace una frase monstruosa en un giro de aliento que alberga una pausa entre tono y tono.

Aguamarina es una piedra dura, es un peso en el cabo de la cuerda que me mete al mar. Tengo una lengua, una sola, que no es la mía.

E'lbi, E'lbi

As my language is whipped by other tongues it turns into a safe haven for the idioms of the past and present. I strive for the meridians which disappear every time poetry visits me:

Una pizca de sal muerde la herida (from: El Meridiano)

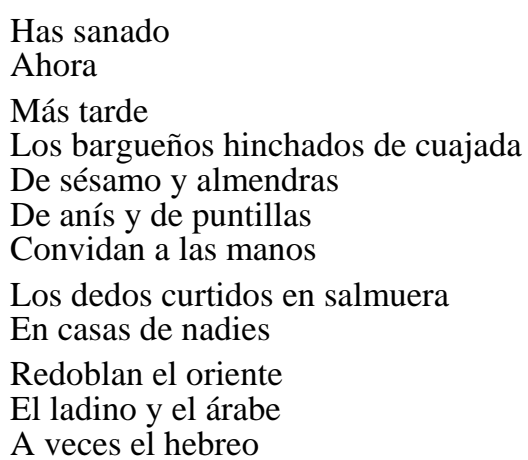

And this is how the echoes of these voices, of these languages, of these smells and tastes cradle themselves in the poetic word that in- 
habits me, a word that has its shelter in Castilian, to which I pay tribute, for it treated me to its special eleven-syllable rhythm:

Si lo hablado es memoria en la palabra

y lo escrito memoria de memoria

en el poético decir se labra

la doble marca que se llama historia

Y la lengua se teje en otras lenguas

con hebras de tramado castellano

mosaico de las voces que sin mengua

nombran la esencia y también lo vano

Cada decir con los decires suma

todo el idioma y todas las presencias

y el castellano leve como espuma

el peso lleva de numerosa herencia

En el árabe dice de hermosura;

en el sefaradí de la mancura;

y en el talit sagrado la blancura;

y en el Libro consagra la escritura

Y pliega en capas y mantos de leyendas

de lágrimas, dolores, y de ofrendas

el salmo, el versículo, el poema

el largo cuento y el tenaz emblema. 


\section{Anna Akasoy \\ Exile and Alienation in the Poetry of the Early Southern Mahjar}

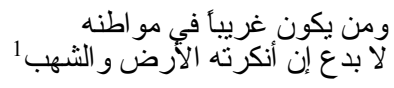

During the two decades before and after the turn of the twentieth century the Levant witnessed a mass exodus unprecedented in its history. Famines, political violence, oppression and in general the severe socio-economical crisis the Ottoman Empire suffered during the last years of its existence drove substantial numbers into exile, above all members of the Christian confessions. ${ }^{2}$ At the same time the shores of far away lands bore the promise of a new life of freedom and economical prosperity, often triggered by the agents of shipping companies. The principal destiny of the Levantine - as well as European immigrants in those years were the U.S.A. and Canada, followed by Latin America, Australia and to a lesser degree West Africa. Due to a lack of records, especially in the early years, it is difficult to estimate the scale of this migration. Typically, the immigrants from the Middle East worked as merchants of imported goods and, as in many other parts of the world, their story was one of great success. Well-working family structures as well as an eagerness to find a better life in the "new world" stimulated the establishment of social communities with a high reputation, political and economic power and an impressive cultural life. In contemporary Latin American literature the Levantine trader still constitutes the typical Arab, or "Turco", as they are usually called. We come across these figures in Gabriel García Márquez' El amor en los tiempos del cólera as well as in Milton Hatoum's Relato de um certo Oriente. The migration from the Levant turned out to be

1 "If somebody lives in a foreign place it is not surprising if earth and stars also consider him a stranger." From: Amānī muhäjir ("Wishes of an Immigrant") by Fawzī al-Ma'lūf. I am grateful to Magnus Ryan for correcting the English version of this article.

2 Karpat (1985); Hourani/Shehabi (1992). 
decisive not only for the development of the host countries, but also for shaping the identity of the Lebanese as a global community.

Already during the early years of Arab presence in the Americas many immigrants engaged in publishing activities. Apart from being a means of communication for the local communities, these publications offered an opportunity for the newcomers to continue their literary traditions and at the same time - under the influence of their host cultures - develop a new tradition, the so-called adab al-mahjar ("exile literature"), often also referred to as Arabic Romantic literature. ${ }^{3}$ The intellectual life of Arabs in exile was influenced by two currents. On the one hand it was under the sway of the so-called Arab Renaissance (nahda). Spiritualist approaches to the nature of the human soul for example are characteristic of many texts of the mahjar literature, and similar discussions were led in newspapers in the Arab world. These concerns betray general tendencies of a new Neo-Platonism and freemasonry which were popular among Arab intellectuals at that time (Hourani 1962: 246sqq.). Another element which nahda and exile literature have in common is - connected with the downfall of the Ottoman Empire - a new rise of Arab nationalism and pride in Arab history and culture. The second important source of inspiration for the poets of the mahjar was European literature the Arab Romantics became acquainted with during their education at missionary schools or later in their host countries. Meanwhile Blake, Keats, and Shelley enjoyed popularity among the poets of the North American mahjar (Abdel-Hai 1980), Baudelaire, Musset and other French poets were read in the South.

According to the Arab Romantics and similar to European models, the contents of a poem should have the primacy over its form. They rejected the artificial use of a never-changing corpus of classical topoi and unusual words prevailing in classical Arabic poetry, ${ }^{4}$ as well as the concept of the poet who composes his verses above all to please and praise his patron. The Romantic poet shared with the Neoclassic poet (e.g. Ahmad Shawqī) the idea of the poet as an advocate for his

3 al-Na ūrī ('1977); Ostle (1992); 'Abd al-Dā'im (1993); Scheffold (1993).

4 The Romantics as well as later poets were often quite harsh in their criticism and did not take into consideration the enormous developments which separate preIslamic Bedouin poetry from the poetry composed at the early Abbasid courts, not to mention Arabic poetry in the Mamluk or Ottoman era. 
nation in political contexts. A new aspect was the concept of the Romantic genius which is reminiscent of the pre-Islamic shä ir. According to this concept, the Romantic poet is distinguished by a singular emotional sensitivity which allows him access to a superior sphere of reality and to travel between the ordinary people's material world and the divine realm. With his exceptional insights the poet is able to develop a vision of the authentic in a corrupt world. As for the European Romantics, the aesthetically, the ethically, the spiritually and the politically authentic often converged. Likewise, in both traditions nature plays the role of a mediator between these opposed spheres. In Neoplatonic terms it is an emanation of the divine, and in terms of epistemology it serves as an object of contemplation and as a gate to the cognition of the superior sphere. In Arabic literature this role of nature is, with a few exceptions, ${ }^{5}$ unique to Romanticism.

In general textbooks on Arabic literature little attention is usually paid to mahjar Romanticism which is often regarded as an unimportant prelude to modern Arabic literature. Sometimes it is even ridiculed for a certain naive spiritualism and an exaggerated self-pity which can be found in several examples of mahjar literature. However, regarding the entire genre in those terms would do it injustice. In particular the literature of the Southern mahjar has remained largely unexplored in spite of the continual popularity of poets like Rashīd Salīm al-Khūrī ("al-Shācir al-Qarawī̄) or Ilyās Farḥāt in the Middle East. Another member of this generation of Arab poets was Fawzī alMa'lüf ${ }^{6}$ who in what follows will serve as an example to describe general features of the poetry of the Southern mahjar.

Fawzī al-Maclūf was born in 1899 in Zahlé, a Lebanese town in the Bekaa valley predominantly inhabited by Christians. In his family, which included several other mahjar poets, Fawzī al-Ma'lūf became familiar with classical Arabic poetry. During his time at the Catholic Collège Oriental in Zahlé (1909-1913) he is supposed to have composed his first pieces of poetry which are not preserved. His further

5 The Abbasid poet Ibn al-Rūmī (836-896) and certain examples of mystical and Andalusian poetry, cf. Schmidt (1971).

6 Aoun (1939); 'Abd al-Shāhid (1971); Akasoy (2002). The primary sources used for this article were published post mortem as Dīwān Fawzì al-Ma'lüf (al-Ma'lūf 1957). 'Abd al-Shāhid included in the appendix of his book some additional poems published in different magazines. 
education at the École des Frères in Beirut was interrupted by the beginning of the First World War which forced the young poet to return to his native city. During those years he translated some pieces of French literature and wrote the drama Ibn Hämid on the fall of Granada $^{7}$ and two short novels. In 1919 Fawzì followed his father to Damascus where he encountered a more nationalistic atmosphere than in Beirut. Some political ideas he expresses in his exile poetry might result from this time. Only two years later the young poet had to leave Damascus and once again followed his father, this time to join his uncle Qayșar in São Paulo. The reasons for his emigration have never been adequately explained. Some authors assumed an unhappy love to be the main reason whereas others suggested a pressure to realise his literary talent or, more generally, the depressing atmosphere in the Levant caused by the new foreign rule after the end of the Ottoman dominion. Ma'lūf's political poems give evidence of a certain ambiguity of motives, as we shall see later. When Fawzī al-Ma'lūf arrived in Brazil in 1921, he encountered a well established Lebanese community there. He integrated himself successfully into their cultural, social and economic circles and became a respected member of the community, but he died in 1930, two years before the 'Usbah Andalusiyyah (Andalusian League) was founded, a literary circle similar to the famous Räbitah Qalamiyyah (Pen Club) in New York.

Among the recurrent themes of Ma'lüf's poetry is a strong feeling of exile and alienation which affects several layers of the poet's self. The most obvious layer is the exile from Lebanon. None of Ma'lüf's poems contains a description of his new Brazilian home, let alone one which gives evidence of a new positive source of inspiration. ${ }^{8}$ Most of the poems in which Ma lüf deals with his exile emphasise the painful longing for the Levant, declarations of loyalty, and obstacles to these feelings of affection and longing. Another layer of alienation is the

7 For al-Andalus as a historical utopia in modern Arabic literature cf. Nijland (1987), Martínez Montávez (1992), Akasoy (2002: 29sqq.).

8 This absence of descriptions of the place of exile is not uncommon in Arabic poetry. It is typical of the first generation of mahjar poets who did not expect to remain in exile, but it applies also to the Neoclassic poet Ahmad Shawqi who spent several years of exile in Spain. His poems on Spanish items, however (The New al-Andalus, Andalusiyyah, Journey to al-Andalus), deal with the glorious Moorish past and hardly contain references to contemporary Spain (cf. BoudotLamotte 1977: 53sqq.). 
Romantic's feeling of exile in the material world and his eternal quest for the authentic. In what follows, I will discuss these two cases of alienation using as examples the poem The Empty Lions' Thicket and the poetical cycle On the Carpet of the Wind.

\section{Political Alienation: The Empty Lions' Thicket}

Ma'lūf composed The Empty Lions' Thicket (al-Mas'ada al-khāliya) ${ }^{9}$ in 1921 when he left Lebanon for Brazil. The poem begins with an invocation of the pain the poet suffers by being separated from his homeland. The motives Ma lüf uses are borrowed from the nasīb of early Arabic poetry, i.e. the first part of the qasidah in which the poet laments the departure of the beloved (II. 1-3):

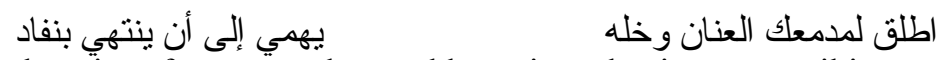

Let go the reins of your tear duct and leave it so that it pours until it runs dry.

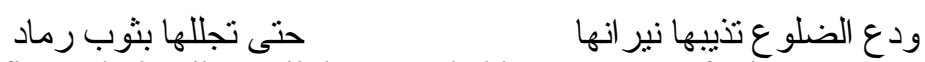

Let the fire melt the ribs until they are clad in a garment of ashes.

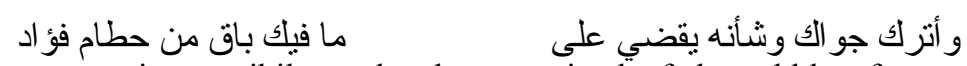

Let your passion annihilate what has remained of the rubble of your heart.

In the first part of the poem Ma'luff demonstrates both his familiarity with classical Arabic poetry and his own contribution to this tradition, an intense emotional language. He also sets the stage for the political message he conveys in this piece. The first impression we get of the poet is that of a victim. The fact that Ma'lüf refers exclusively to his emotions deprives his possible critics of any opportunity to question his role as a victim and reproach him for abandoning his fatherland for base motives. In the next part of the poem the poet invokes the memory of a paradisiacal homeland which offered emotional comfort as well as poetical inspiration (11. 7-8):

$$
\text { و هو الك بسام وفكرك هادي }
$$

أيام كنت به و عيشك ز اهر

When you were there your life was beaming, your mood smiling and your thought calm.

9 al-Ma'lūf (1957: 25-28), German translation in Akasoy (2002: 288-291). 


$$
\text { تتصبد اللذات بين رياضه }
$$

Delights chased over its meadows and on your eyelids was the drunkenness of a hunter.

In this part Ma'lūf leaves the exclusively inner sphere and makes use of a different point of reference, the memory of himself in his homeland which implies a more ample context than the poet's innermost emotional state. A noteworthy aspect of this description is that whenever Malūf describes Lebanon in terms of the Garden of Eden, it is never inhabited. ${ }^{10}$ He rather invokes an existential and very intimate, almost maternal relationship with his home. By describing himself as a favoured, nourished and blessed son of Lebanon, Ma'lūf provides himself with a sound background to present his political claims. As soon as other people enter the stage, the description of Ma'lüf's homeland becomes critical or at least ambiguous. In the following lines of The Empty Lions' Thicket Ma'lüf combines this powerful emotional language of longing with a description of the motives for migration which reinforce his role as a victim (II. 13-15):

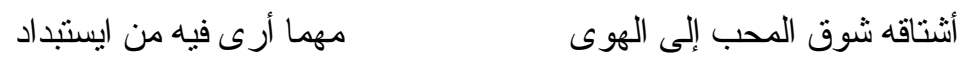
I long for my homeland with a lover's passion, whatever despotism I see there.

$$
\text { منه و أمحضنه صحيح ودادي }
$$

I love it in spite of what reaches me from there, and I declare that I truly love it.

$$
\text { فالأهل أهلي و البلاد بـلادي }
$$

مهما يجر وطني علي و أهله

No matter how much my homeland and my people have wronged me, because its people are my people and this land is my land.

With these lines we get a taste of Ma'lüf's general attitude in his political poems, a sometimes rather vague criticism of the state of political oppression, misery and injustice. A paradox which arises from the contrast of the paradisiacal homeland and the crisis of separation is that with the departure from his home the poet is bereft of his unique source of inspiration. But, as becomes clear from the following lines, this loss is at least partly compensated by the deep feeling of grief (I. 16):

10 For the homeland described as Paradise Lost and object of criticism for contemporary political conditions cf. Nijland (1989). 


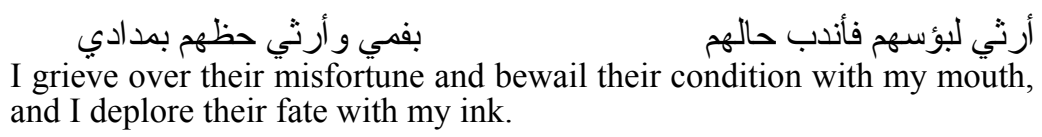

In the final part of the poem Ma'lüf repeats his declarations of loyalty and avows that all criticism directed against his compatriots stems from honest intentions. Nevertheless, his words are harsh when he reaches his concrete reproaches (11. 22-24):

$$
\text { يتفاخرون بنير الاستعباد }
$$

و استعذبو ا ذل القيود فأصبحو ا They enjoyed the shame of the bonds and began to praise themselves for their slavery.

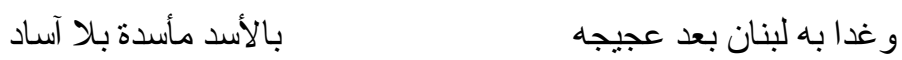

By way of this, Lebanon became an empty lions' thicket after having roared with the lions.

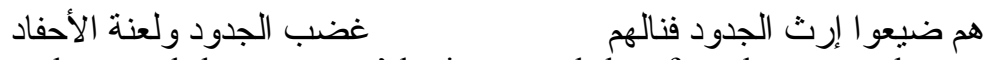

They destroyed the ancestors' heritage, and therefore they meet the ancestors' fury and the descendants' curse.

In particular this last line bears a serious reproach. As the poet himself demonstrates in his poems about historical themes like Baalbak, the Phoenicians and Granada, ${ }^{11}$ the glorious times of the past are a constitutive part of his identity. As for the representatives of the nahda as well as for the European Romantics, a nation's cultural legacy has an almost sacred status and imposes a heavy responsibility on the modern upholders. The description of Lebanon as Paradise Lost furthermore constitutes a parallel to love poetry with its idealised past and criticised present, except that the past in love poetry is an individual one, whereas the historical past is collective. The reproaches also reveal a different layer of political alienation Ma'lüf experienced even before his migration. Lebanon is denied its existence in an appropriate condition since its people in their disorientation even support foreign rule.

With this second, political, description of Lebanon Macluff creates a clear contrast between the authentic land of his memory which is pure and paradisiacal on the one hand, and on the other hand the corrupted land of a society which is not authentic, but guided by misperceptions. The way this society treats their land corresponds to the

11 Two of these poems are not Ma'lüf's original compositions: Oh Granada! is based on the Spanish poet Francisco Villaespesa's Elegía, The Phoenicians is a translation of a poem by the Brazilian Olavo Bilac (cf. Akasoy 2002: 128sqq.). 
way it treats the poet, the herald of their land's inner voice. Yet, in the final lines of The Empty Lions' Thicket one might perceive a certain self-criticism of Ma'lüf when he declares (I. 26): ${ }^{12}$

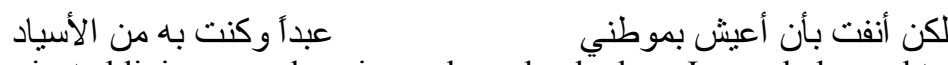

But I rejected living as a slave in my homeland where I once belonged to its masters.

The poem ends with a reference to the poet's emotional situation and his physical condition as a traveller on the sea. It gives a last impression of Ma'lūf's conflicting feelings and mutually exclusive wishes (1. 28):

$$
\text { البحر تحتي و اللظي في أضلعي }
$$

Under me is the ocean, and between my ribs a blazing fire, there is water around me, but my heart is thirsty.

In The Empty Lions' Thicket Ma'lüf presents both an apology and an attack. His argumentative strategy is carefully developed. In choosing his innermost emotional condition as a starting point, Ma'lūf creates the ground for an interpretation of his situation which can hardly be challenged and which serves at the same time as a basis for his political criticism. In Amānī muhājir ("Wishes of an Immigrant"), ${ }^{13}$ another poem written at the time when the poet left Lebanon, Ma'luf proceeds in a similar way by conveying a political message in the context of an account of his situation as an expatriate. He also begins with a description of his suffering, but when he turns to the political criticism he includes himself among those who are criticised for their failure. Also, unlike The Empty Lions' Thicket, Wishes of an Immigrant contains a passionate plea for a solution to Lebanon's numerous problems:

تاله لا نرتقي إلا متى اتحدت By God, we will not advance unless the minarets and domes (of Christian churches) in our homes are united.

12 This self-criticism is more explicit in Wishes of an Immigrant. There, Ma'lūf blames himself for having abandoned his fatherland: "Had it not been for a deceiving strife for superiority, by God, I would not have left their territory for distant lands".

13 The Dìwān contains only an abbreviated version (Ma'lūf 1957: 30-32). A complete version is available in the appendix to 'Abd al-Shāhid (1971: 22-24). 
وإنه للتآخي و العلى سبب النكرم العلم أيا كان مصدره fraternisation and sublimity.

فالعلم كالنور لم تحصر به نزب

لا دين للعلم في الدنياو لا وطن

In this world knowledge has neither confession nor homeland, because knowledge is like the light which is not restricted to a place.

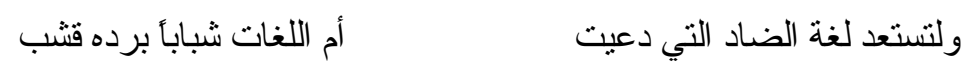

May the language of $D \bar{a} d$ (= Arabic) which was once called the mother of languages regain its youth in a new garment.

فنحن تحت لو اها كلنا عرب

إن لم نكن كلنا في أصلنا عرباً

If not all of us have Arab roots, we are all Arabs under the banner of this language.

As in other political poems composed on particular occasions, often the death of a respected personality, Fawzī al-Ma'lüf appears as an ardent partisan of Arab nationalism. Despite the spiritualist concerns and a critical attitude to rationalism revealed in other cases, his support of secular enlightenment in the political poems is by no means uncommon for a Romantic poet and can also be detected in the European models.

\section{Spiritual Alienation: On the Carpet of the Wind}

Rather than the memory of the idealised home, the trauma of exile constitutes the prevailing theme of Ma'lüf's spiritualistic poetry. The poet's spiritual alienation is even more fundamental than the loss of identity caused by exile and foreign rule of his homeland. It is the Romantic poet's essential alienation from the spiritual home of all mankind. Whereas the vast majority of human beings are ignorant of their origins, the Romantic poet is endowed with an exceptional sensitivity which allows him to feel both the pain of separation from the spiritual home and the bliss of re-approaching it. In Romantic poetry nature serves as a mediating sphere between the corrupt world of human society and the spiritual home. It is to nature that the poet in Ma'lüf's poetry retreats, seeking isolation from human corruptness and contemplation of the pure and authentic. His spiritualistic poems reveal a notion of strangeness which occupies a more important position in Khalil Jibran's works (Naimy 1974; Dahdah 1997) than it does in Ma'lūf's. Fawzī Ma'lūf's best known work, the cycle On the Carpet 
of the Wind ('Alä bisāt al-rìh), ${ }^{14}$ describes the poet's journey from the material to the spiritual world in fourteen cantos. In this cycle one can discover some of the most important features of Ma'lüf's poetry which are sometimes also characteristic of early mahjar poetry in general.

On the Carpet of the Wind begins with a description of the poet as "a king in the air". The heavenly spheres are not only his true home, but he rules there. The clouds are his throne, darkness his shawl and the Pleiades his sceptre. As in European Romantic poetry it is the night, Ludwig Tieck's "mondbeglänzte Zaubernacht" (Wunder der Liebe) or Joseph von Eichendorff's famous "Mondnacht", which offers the opportunity for an access or a return to this super-material realm (Abdel-Hai 1975). There the poet governs not with physical force, but with the power of his fantasy and his poetry. The superiority of the heavenly spheres is evident not only from their inhabitants' reverence for the poet, but also from its physical appearance. Eagles, stars, the Muse, and spirits inhabit a realm of pleasant smells, dreams and eternity, symbolising a sensual, spiritual and metaphysical excellence which distinguishes this place from the material world. The poet-king however is in an ambiguous situation as a being which consists in part of flesh and bones and thereby partly belongs to the material world:

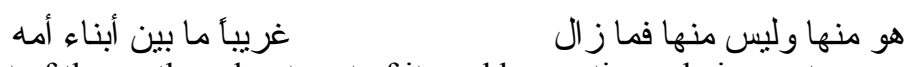

He is part of the earth and not part of it, and he continues being a stranger among his mother's children. ${ }^{15}$

In the second canto (The Spirit of the Poet) the language of political power turns into one of metaphysics with the description of a supernatural power which might be identified as the poets' collective spirit as well as the Neoplatonic world-soul. In this cosmological scheme poetry is a manifestation of the divine, but even more so has itself a powerful impact:

14 al-Ma'lūf (1958). The Portuguese version by Venturelli Sobrinho (No Tapete do Vento, Poema árabe por Fauzi Maluf, Rio de Janeiro 1931) gives evidence of Ma'lūf's popularity in Brazil which went beyond the Arab community (cf. Akasoy 2002: 208-225, 248-287).

15 William Chittick describes a similarly ambiguous state of being and not being for the great Islamic mystic Ibn 'Arabī (cf. Chittick 1989). 


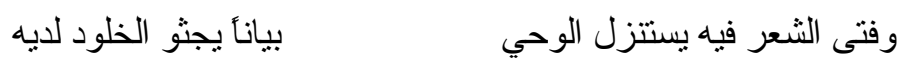

The young man of poetry invokes the inspiration as a revelation before which eternity bends its knee.

The poet-prophet creates the material world which appears as a reflection of his emotions:

$$
\text { رشفته الأزهار من محجريه }
$$

ماندى الفجر غير لؤلؤ دمع What is the morning's dew if not the pearls of his tears the blossoms drew from his eyes.

$$
\text { كأس حب تحطمت في يديه }
$$

And what is the radiance of the stars, if not splinters of a glass of love which broke in his hands.

The third canto (The Slave) bears a strong resemblance to Ma'lüf's political poetry. It contains a dramatic portrait of the poet as a slave of the laws of corporeality who suffers from the fundamental discrepancy of his bound body and his free spirit. Similarly, the patriot suffers from his people's misguided existence as blind slaves. Both are caught in a dilemma of multiple impediments and dependencies which have in common an almost deliberate submission to agony:

$$
\text { ضلة عن لبابه بقشوره }
$$

عبد عصر من التمدن نلهو

I am a slave of an epoch of civilisation, and we enjoy its vainness while removing ourselves from its best part.

$$
\begin{aligned}
& \text { فكوى أضلعي بنار سعيره } \\
& \text { عبد حبي أنزلته في فؤ ادي }
\end{aligned}
$$

I am a slave of my love which I let descend into my heart, and my ribs burnt through its burning flame.

This situation of the poet is reminiscent of the conflicting images of the immigrant: even though the poet in On the Carpet of the Wind possesses a body, he is not entirely subjected to the laws of the material world. He remains in a state between both worlds which allows him to understand his condition as a material being. Despised and underestimated by the common people, the poet is not capable of applying these insights to his life as a member of a social or political community. As long as he remains in this society, he has no choice than to support, continue and perpetuate these conditions. Similarly in Ma'lüf's political poetry the poet's position remains ambiguous. $\mathrm{He}$ complains and suffers, but at the same time he is consciously part of the problem. But here as well he does not have the power to improve the situation since the people neither appreciate his poetical talent nor 
his metaphysical, ethical and politico-historical insights. Temporary and limited relief is granted by a retreat to nature or exile. In both cases the only comfort is the poet's free spirit which travels without any physical impediments to the poet's true home, the heavenly spheres or the paradisiacal Lebanon of his memory.

The fourth canto (Dream and Reality) emphasises the material character of the poet's journey and reveals the comical dimension of Ma'lüf's poetry. Not fantasy alone carries the poet's body to the place "where his spirit lives without his body". It is the birds and, most curiously, an "aircraft on the back of the wind". Ma'lüf showed his fascination with this new means of transportation already in his short poem The Samkh Disaster (published 1924) which deals with the first plane crash in Ottoman history. ${ }^{16}$ In On the Carpet of the Wind he describes his miraculous machine as:

الجن في صدر ها تحثّ خيو لا

هي طبير من الجماد كأن

A bird made of inanimate matter as if a jinn in its chest spurred on horses.

With the fourth canto the stage of On the Carpet of the Wind is set and its various dimensions are laid out. In the fifth canto (Among Birds) the poet arrives to the lowest sphere of the sky which is inhabited by the birds which react primarily to the terrifying outer appearance of the poet. An eagle wonders what sort of creature this is:

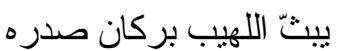

با له طائر أ بصورة شيطان

He has a bird in a devil's shape, and the volcano in his chest sends out flames.

Another bird realises they are facing the visit of a human being. Close as they live to the earth, the birds are left in no doubt about the character of these creatures and fear the conquest of their realm:

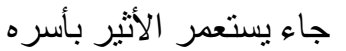

آدمي هذا أجاب أخوه

This is a human, his brother answered, who came to inhabit the entire ether.

16 al-Ma'lūf (1957: 23-24). Further examples of Ma'lūf's much neglected humoristic poetry are $O$ Nights of Mud, When Does the Morning Come, a parody on love poetry where he describes himself as stuck in the mud of Damascus' Bāb Tūmā, The Vendor of Love, a negative inversion of the description of the beloved directed to a prostitute, and The Cigarette, which compares this object with the beloved (cf. Akasoy 2002: 52sqq.). 


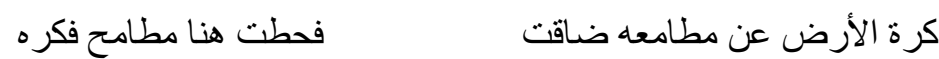

The earth has become too narrow for all his purposes, so that his desires settle here.

The birds decide to attack the poet who defends himself with declarations of his pure intentions. He came to delight the birds with his poetry and left the earth for the same reasons as they did, to escape the pain caused by its inhabitants. This defensive speech is continued in the sixth canto (Signs of Pain) in which the poet portrays the life in the material world to the birds and describes how poetry is the only way for him to take relief from this existential dilemma. In accordance with the impact of poetry described in the second canto, the poet's soul discovers paradise in its quest for the phantasmagorical. The muddy rivers of the material world turn into the Salsabil, the river of Islamic paradise, and the poet fills the heavenly sphere with a song which is perceived by humans as a religious revelation.

In the seventh canto (Close to the Stars) the poet's confrontation with the birds is repeated when he reaches the next sphere, which is inhabited by the stars. Again, the first star wonders what sort of creature has entered their realm, and the second star identifies him as an inhabitant of a planet named Earth which is full of misery. But since these beings are unable to sustain themselves in the upper spheres the second star recommends no attack. In this and the following canto (Scattered Leaves) the poet addresses one of the stars as the star he had been talking to in his lonely nights in the gardens and begs for the star's sympathy. The comfort the star and his poetry have given to the poet proved to be vanishing illusions ousted by pain:

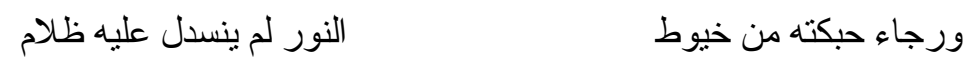

Which hope have you woven out of threads of light which darkness did not descend on?

$$
\text { لم يعكره بالأنين الغر ام }
$$$$
\text { و نشيد وقعته للتنأسي }
$$

Which song you have sung as a comfort has not been blurred by the sigh of ardent desire?

In the ninth canto (In the World of the Spirits) the poet meets the third party, the spirits. Like the birds and the stars they react to the poet's arrival with curiosity and approach him in order to find out what kind of being he is and where he comes from. At first the poet hears their whispers and senses their windy touches. He understands only after a 
while their whispered words which are the contents of the tenth canto (A Handful of Dust). Like with the inhabitants of the lower spheres, a first spirit appears demanding the poet's expulsion. Even though there is no need to be afraid of him, as a being of clay and water he does not belong to their sphere. His body depends on the principles of generation and corruption, and so does his power on earth. This spirit's speech describes the poet's existence in the material world in clear contrast to the version of the second canto. According to the spirit a human's death bears more advantages than his life. The decay of a body offers at least nutrition to the plants. The idea of death as life appears frequently in Ma'lüf's poetry, but is usually rendered in terms of a disposal of physical bounds and the birth of the free spiritual self.

In the eleventh canto (Deceptive Progress) another spirit deepens this criticism and depicts the human being as morally corrupt, thereby reinforcing reproaches already uttered by the birds and the stars. Instead of using his reason and knowledge to improve his living conditions, man turns earth into hell, and the more developed human cultures appear to be, the more they destroy. He also alludes to the poet's flying machine:

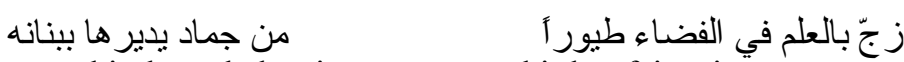

Man sent out his knowledge into space as birds of inanimate matter, which he revolves with his fingertips

$$
\text { ما بناها إلا لهدم المباني لسفك الدماء في طير انه }
$$

But he constructed them only to destroy buildings and shed blood during his flight

$$
\text { الويل في الكون من نهى إنسانه }
$$

If only he did not possess reason, since all disasters on earth result from man's intellect

With this repeated criticism of technical progress and rationalism Ma'lüf reveals an attitude to the development of human civilisations which is in many ways similar to that of the European Romantics. Even though not entirely opposed to reason (as one can see from the demand of enlightenment in the political poetry) the Romantics drew attention to the deep ambiguities hidden in a development which only seemingly leads to the benefit of mankind. In reality however, as Adorno and Horkheimer pointed out in their Dialectics of Enlighten- 
ment, this process implies a further alienation of mankind from its authentic existence and, ultimately, self-destruction.

Finally, in the twelfth canto (The Atonement of the Poet), the poet's own spirit appears and defends the human visitor. According to this spirit the poet's life on earth is only suffering and by no means voluntary. If he had the choice he would prefer the darkness of the grave, and with his enormous emotional pains he purifies his soul which had been intoxicated with material desires. The poet's spirit pleads with the other spirits to leave the poet in peace since he came to their sphere in search of a comfort granted only by his spirit:

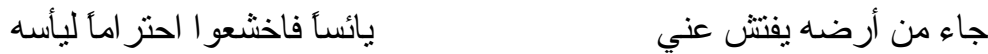
He came from his earth full of despair and in search for me, so please be humble and respect him for his despair

$$
\text { شهد عطف ينسيه علقم كأسه }
$$

Let him be with me, because in my kisses is tender honey which makes him forget the bitter taste of his chalice

In the thirteenth canto (On the Carpet of the Wind) the poet and his spirit meet as lovers in a sphere full of passionate love. They kiss and enjoy themselves by observing human beings walking on the earth like ants. This, again, underlines the material character of the poet's journey and Ma'lüf's fascination with the possibility of flying. After this encounter the poet has to return to the realm of slavery and materiality in the fourteenth canto (On Earth). Only his poetry comforts him now, the only paradisiacal and authentic element in the material world capable of rendering the poet's emotional states.

On the Carpet of the Wind is rightly regarded as one of Ma'lüf's masterpieces. For conveying his messages about the state of mankind he chose an original version of a topos which is well known in world literature. Even though his journey to the heavenly spheres depends on a sharp contrast between the material and the spiritual world, he does not operate merely with the platitudes sometimes connected with such worldviews. The emphasis on the material character of the journey and the impressively composed episodes about the inhabitants of the different spheres provide the cycle with an almost carefree atmosphere which lacks the gravity of a metaphysical and moral discourse. But Ma'lūf's lamentations and admonitions are to be taken seriously. $\mathrm{He}$ suffers from being a misunderstood and underestimated spirit in the 
material world which grants him no comfort. But there are the heavenly spheres he retreats to with their inhabitants who are often addressed by the poet in his lonely nights. Even though Ma'lüf reveals a pessimistic worldview, it does not seem impossible to change the condition of human societies. Otherwise, any political criticism would be entirely futile. Finally, the last canto ends with a positive vision of poetry as an opportunity of retreat in the material world.

Ma'lūf's political and spiritual poems have much in common. Both convey a similar notion of exile and alienation. In both cases the poet is depicted as exiled from a home he is essentially connected to in many ways. When his fantasy or memory carries him back there, he evokes an intimate relationship which sometimes even has an erotic notion (e.g. in the encounter with his own soul in On the Carpet of the Wind). But it is not only an individual's home: as a Romantic poet Ma'lüf claims that it is a sphere of pure authenticity which applies to all mankind in different respects, metaphysical, moral, aesthetical, spiritual, and sensual. The poet's heightened perceptive capacities grant him access to this sphere, and his exceptional capacity of expression allows him to put his insights into words which have the potential of illuminating mankind. Ordinary people, however, are misguided and react with misunderstanding and opposition. The poet is thus faced with an eternal change between a comforting home where he is truly appreciated and a hostile place of exile. His fate is the condition of a traveller who is time and again bereft of his home and experiences deep pain; but the pain is the price he pays for being a mediator between the worlds.

\section{Bibliography}

'Abd al-Dā'im, Șābir (1993): Adab al-mahjar, Dirāsah ta'sīliyyah tahlīliyyah. Cairo: Dar al-Ma'arif; al-Tab’ah.

'Abd al-Shāhid, Șamū'īl (1971): Fawzì al-Ma'lūf (1899-1930). Sìratuhu, adabuhu, fannuhu. Beirut: American University of Beirut (MA thesis).

Abdel-Hai, Muhammad (1975): "Night and Silence: Experience and Language in Romanticism and Mysticism". In: Journal of Arabic Literature 6, pp. 107-124.

- (1980): English Poets in Arabic, The Arab Romantics' Knowledge of English Poetry (1900-1950). A Study in Comparative Literature with a Bibliography of Arabic Translations of English and American Poetry (1830-1970). Khartoum: Khartoum University Press. 
Akasoy, Anna (2002): Arabische Romantik im Exil, Das poetische Werk des Fauzī alMa'lüf. Wiesbaden: Reichert Verlag.

Aoun, Faïez (1939): Fawzì Ma'lüf et son ceuvre. Paris: University of Paris (PhD thesis).

Boudot-Lamotte, Antoine (1977): Aḥmad Šauqī. L'Homme et l'ouvre. Damascus: Institut Français de Damas.

Chittick, William (1989): The Sufi Path of Knowledge. Ibn al-'arabi's Metaphysics of Imagination. Albany, N.Y.: State University of New York Press.

Dahdah, Jean-Pierre (1997): Khalil Gibran. Eine Biographie. Zurich/Düsseldorf: Walter.

Hourani, Albert (1962): Arabic Thought in the Liberal Age, 1798-1939. London: Oxford University Press.

Hourani, Albert/Shehabi, Nadim (1992) (eds.): The Lebanese in the World. A Century of Emigration. London: Centre for Lebanese Studies in association with I. B. Tauris.

Karpat, Kemal (1985): “The Ottoman Emigration to America, 1860-1914”. In: International Journal of Middle East Studies 17, pp. 177-209.

al-Ma'lūf, Fawzī (1957): Dīwān Fawzī al-Ma'lūf. Beirut: Dār Rīhānī.

- (1958): 'Alā bisāt al-rīh. Beirut: Dār al-Sādir/Dār al-Bayrūt.

Martínez Montávez, Pedro (1992): Al-Andalus, España, en la literatura árabe contemporánea: la casa del pasado. Madrid: Editorial MAPFRE.

Naimy, Nadeem (1974): "Mind and Thought of Khalil Gibran". In: Journal of Arabic Literature 5, pp. 55-71.

al-Na'ūrī, 'Īsā ( $\left.{ }^{3} 1977\right)$ : Adab al-mahjar. Cairo: Dār al-Macārif.

Nijland, Cees (1987): “A New ‘Andalusian’ Poem”. In: Journal of Arabic Literature 18, pp. 102-120.

- (1989): "The Fatherland in Arabic Emigrant Poetry". In: Journal of Arabic Literature 20 , pp. 57-68.

Ostle, Robin C. (1992): "The Romantic Poets". In: Badawi, Mohamed Mustafa (ed.): Modern Arabic Literature. Cambridge: Cambridge University Press, pp. 82-131.

Scheffold, Margot (1993): Doppelte Heimat? Zur literarischen Produktion arabischsprachiger Immigranten in Argentinien. Berlin: Klaus Schwarz.

Schmidt, Werner Christian (1971): Die Natur in der Dichtung der Andalus-Araber. Versuch einer Strukturanalyse arabischer Dichtung. Kiel: University of Kiel (PhD thesis). 



\section{Elias Khoury}

\section{Literature and Emigration}

In the villages of Mount Lebanon, there is a special category of land that still keeps its name from the beginning of the century. Actually one can find this name in nearly all the villages. "The land of the return". This is how the Lebanese villagers named the pieces of land bought by emigrants in the Americas who were dreaming of the moment they could come back home from the New World.

The name is still there, "this is the land of the return of so-and-so", a villager will tell you in the year 2004, and when you try to ask about the emigrant after whom the land was named, no one will have the answer, as if the name of the piece of land had become its owner, and the memory of the tragic nostalgia that haunted the emigrants had become a geographic reality.

The story of the Lebanese emigration is a long one; it actually began in the late $19^{\text {th }}$ century with the crisis of the silk industry, reached its peak after World War I and the terrible hunger that dominated the Lebanon.

A total destruction of the agriculture of the blackberry tree, with the emergence of industrial silk, and a society dominated by poverty and social disorder lead to a total social change where one third of the Lebanese population died from starvation, another third emigrated, and what was left behind was a remnant of a people.

This is not a special Lebanese case, one can see something similar happening in Syria and in Palestine, as if the so-called "Fertile Crescent" had to begin its relationship with modern times through the memory of social catastrophes.

But intellectual emigration began some time before the massive one towards the Americas. By the end of the nineteenth century Lebanese and Syrian intellectuals began their voyage towards Egypt. Lebanon and Syria were at that time under Ottoman rule, whereas Egypt was under the Muhammad 'Alĩ dynasty, which lost the independence of the country to the British Empire. 
In my paper I will try to introduce the impact of these two emigrations on the development of Modern Arabic literature and on the turning point of both the Nahḍa (Renaissance) and the Hadātha (Modernism).

One of the major figures of the Nahda is the Lebanese writer Aḥmad Fāris al-Shidyāq (1804-1887), a Christian Maronite who converted to Islam after the assassination of his brother by the Maronite clergy because of his Protestant tendencies. Although al-Shidyāq was the first translator of the Bible, and his major work was, like for all the Nahḍāwīs, in the project of appropriating the Arabic language and its modernization, on the other hand he managed to open a new chapter in literature through his formless prose. He wrote in a combination of the maqāma, the literature of voyages and autobiography. The importance and innovation of his prose would be rediscovered with the Post-Mahfüzian Arabic novel, when the writers in the seventies and eighties came to innovative forms in the novel based upon the relationship between the memory of the tale and the realities of the language of the present.

In al-Shidyāq's life story two aspects emerge:

1. The image of the writer as a traveler, whose errancy will lead him from Malta to France, to Egypt, to Istanbul. A man who became homeless and whose life-story is based upon the combination of discovery and nostalgia.

2. The marginal, whose religious beliefs are doubted to the point that his body receives tomb in a no man's land, and is neglected in his home village. For the Christians he is a Muslim, and for the Muslims he is a Christian. This lead to him being ignored outside the curriculum in the Lebanese schools.

The story of Ahmad Fāris al-Shidyāq can help us understand the atmosphere of the second half of the nineteenth century that lead to a massive intellectual emigration towards Egypt. In the experience of this emigration, the ideology of enlightenment dominated and new forms were created. Jirjī Zaydān (1861-1914) initiated the historical novel, Farah Anțūn (1874-1922) played a major role in creating the didactic novel, and the new wave of journalism was created by immigrants like the Taqlā's, who created al-Ahräm (1876) which stayed the most prestigious newspaper in Cairo until our days. 
Badī'a Mașābnī innovated the belly dance while Najīb al-Rīhānī turned into the creator of the modern comedy.

In their Egyptian emigration the Lebanese writers, artists and journalists stayed in the continuity of the Arabic language on the one hand, and in the same sphere of cultural and literary questions on the other. It was a kind of interior emigration, as one can say, a journey inside the same linguistic and cultural atmosphere which had its roots in the emigration of Ibn Khaldūn (†1406) or Ibn 'Arabī (†1240) from the Maghrib to the Mashriq, and of which we can still find traces in artists like Āsyā Dághir or Yūsuf Shāhīn and 'Umar al-Sharîf ...

Parallel to this emigration and in the beginning of the new century, a new wave began to take place, but this time to the far west, to both North and South America. A massive immigration that created the image of the turco in the Latin American literature and established the poet-merchant as a prototype for the thousands of Lebanese men and women who went to the New World in order to be able to return and reestablish their lives in their Old World.

In North America, a literary heritage was created by the Rābita al-Qalamiyya, initiated by Khalīl Jibrān (1883-1931) and Mīkhā'îl Nu'ayma (1889-1989), whereas al-'Uṣba al-Andalusiyya was created by a group of writers and poets like al-Shā ir al-Qarawī (Rashīd Salīm al-Khūrī, 1887-1984).

The North American heritage would continue to be effective until the fifties, when the Syro-Lebanese poet Yùsuf al-Khāl (1917-1987) returned from New York, where he had been the editor in chief of the prestigious Arabic Newspaper al-Hudā, and established in Beirut the Shi' $r$ review which would eventually lead a major literary revolution and open the doors to the translations of European and American poetry to Arabic, mainly T.S. Eliot, Ezra Pound and Walt Whitman.

The Mahjarī Literature (the literature of emigration) played an essential role in the modern literary movement on three levels:

1. The Romantic language, which was created in a new revolutionary approach. The influence of William Blake and Nietzsche on Jibrān created a combination of social and poetic revolt in the literary group lead by him in America. One can say that Romanticism took its shape in Lebanon and Egypt through the works of Ilyās Abū Shabaka (1903-1947) and Aḥmad Zakī Abū Shādī (1892-1955), 
and this may be true. But with the Jibrānī new prose and poetry, modern Arabic literature was able to achieve a new simple poetic language. The ambiguity of Jibrān and his diversity as a poet, painter, novelist and essayist opened up the possibilities for him to behave as if he were rediscovering the continent of literature which had paved the way for him as a way of embodying both a social revolution and a prophetic voice.

2. The social change in the struggle against both the feudal system and the influence of the Christian Maronite Church. The voice of Khalīl Jibrān was a turning point in introducing the concept of social cultural revolution in modern Arabic literature. Although one can now say that the Romantic approach of this voice dominated the idea of revolution itself, as if it were limiting it to the realm of writing only, stories like Khalīl al-käfir (Khalil the Atheist) or Yuhannā al-majnūn (The Mad Yuhanna) and a love story like al-Ajniha al-mutakassira (The Broken Wings) are major signs of a change towards social engagement and a rupture with the dominant idea about the role of the poet-writer as a mudabbir, or consultant-writer of the emir or landlord.

The new writer, who is lonely, living through his words and with them, was not created in the land of emigration, but rather an outcome of a huge socio-cultural change in the Arab Mashriq. Writers after the trips to Europe, under the influence of translations, through the independent press and the modern school began to take on a new shape. It was no longer that of the Sheikh, but rather that of a modern lawyer or scholar. Muhammad Husayn Haykal (1888-1956) published the first modern Romantic novel in Cairo in 1913, and then the model of Țāhā Husayn (1889-1973) and 'Abbās Maḥmūd al-'Aqqād (1889-1964) made it possible for a new intellectual related to the university or the press to emerge.

In this sense the new writer in the Americas was part of a movement in the homeland, his project was to return, and maybe he alone was going to be able to achieve a relationship with the piece of land called "return" because his land were his texts.

3. The emergence of a new criticism with Mīkhā'îl Nu'ayma in his book al-Ghirbāl, which introduced new terms and new approaches in the sphere of literary criticism. 
Here also, one can not separate this critical movement from the one that was taking place in the Mashriq. New critical and linguistic approaches began with Jirjī Zaydān in Egypt and developed to become part of the innovation of literary forms in both poetry and novels.

These three elements will turn the first massive literary emigration to a foreign land into an integral part of the search of the Arab Mashriq for its Nahda (Renaissance) and Inbi 'ath (Resurrection), these two vague terms that dominated the Arab Mashriq since the second half of the nineteenth century. The idea of renaissance will put the stress on the linguistic innovation, and on the appropriation of the golden Abbāsid language with the dominant figure of the poet alMutanabbi (†965). The idea of resurrection will pave the way during the fifties of the last century for the massive use of the ancient symbols and myths (under the influence of the poetry of T. S. Eliot). Thus an unseen link with the classical poet or writer was created.

Khalīl Jibrān was the first poet to find the lost link with the idea of the prophet-poet, which is an essential part of the paradigm in the classical Arabic literature. In his book The Prophet, written in English, the Lebanese poet incarnated this image as a kind of reproduction of the classical paradigm: The poet, prophet, and king.

This model will continue to reproduce itself in the modern Arabic poetry, as if the revolution against the classical Arabic model of poetry contained what the Tunisian critic Muhammad Luṭî al-Yūsufi calls the echoing between the texts. From Imru' al-Qays ( $6^{\text {th }}$ century), the poet king, to al-Mutanabbī, the poet prophet trying to become a king, the paradigm will take its archeological mythical dimension with Adam, believed by the Arabs to be the first poet prophet.

Khalīl Jibrān, in his revolt against the beliefs and social practice of the Christian Maronite Church in Lebanon, was able to create a link with the Arabic prose of the Middle Ages, which crossed the very limited borders between religion and literature in the so-called fantastic prose and the stories of the prophets. Although the Jibrāni breakthrough took place in the frame of the Christian symbols (related to a minority in the Arab Mashriq), he paved a new way that was to be reshaped by the literary image of Jesus that we can find in the poetry of Badr Shākir al-Sayyāb (1926-1964) and Mạ̣mūd Darwīsh (*1941). 
This breakthrough would be rationalized with the critical work of Taahā Husayn and will reach its peak with the allegorical novel of Najīb Maḥūz (*1911) Awläd haritna (1959).

In the South American experience one can pick up the significance of the name of the Arab literary circle that was created there: $a l$ - $U s ̦ b a$ al-Andalusiyya, "the Andalusian Group". Although the poetry produced by the members of this group stayed in the Romantic approach and innovated poetry through trying to introduce a new language based upon the image, rather than what the modernizers understood as the rhetoric structure of poetry, what one can point out is the significance of the name. Living in the Hispanic world, they understood that their experience was a kind of revival of the Andalusian renaissance and tolerance.

Unfortunately, they missed two things:

1. That the Arab Andalusian heritage was to become a leading model in the works of many Latin American writers, Borges with his new structuring of the story, García Márquez with the impact of the Arabian Nights on his novels, and Amado with the figure of the turco in his works.

2. Whereas the Andalusian myth was to become part of the myth of loss, it was also Palestine in the poetry of Mahmūd Darwīsh, and this would reproduce itself in many modern literary works.

The literature of emigration was, as we have seen, a kind of return, the nostalgic aspect reflected itself in the romanticizing of the Lebanese village and in the creation of a kind of a mythical literature that was going to find its voice later with the symbolic Romanticism of $\mathrm{Sa}^{\mathrm{i}} \mathrm{i} d$ 'Aql (*1912) and with the colloquial poetry of Michel Trād (19121998) and the Raḥbānī brothers.

The voice and plays of Fayrūz incarnated this approach and created the modern myth of Lebanon. But here one must be careful; the voice of Fayrūz and her songs mystified Palestine and Damascus in the same way as they had done in the Lebanese context.

Two questions must be tackled here:

1. What was the impact of the Lebanese Civil War 1840-1860 on the Mahjarī literature? 
2. What American or European influences did these Mahjarī writers bring to the Arabic culture?

I am not sure that there is evidence that can help us answer the first question. The first Lebanese Civil War that spread to Damascus has entered in the unspoken since a long time. We can find only hints about it in the work of writers that witnessed it, like Shākir al-Khūrī (†1913), but the major writers of the second half of the nineteenth century preferred silence and filled this silence with a national rhetoric.

Nearly the same thing happened in the Americas, the terrible memories of the Civil War were replaced by a kind of modern secular non-religious discourse. Even the experience of the famine of Mount Lebanon during World War One had to wait until the thirties and the new realistic approach of Tawfĩq Yūsuf 'Awwād (1911-1989) in his novel al-Raghiff (A Loaf of Bread).

This gives us the answer to our next question, and we will discover that the Romantic discourse was going to dominate this literature. Although Jibrān went to Paris and Nu'ayma visited Russia, we will not find any influence of the naturalistic and/or realistic literature in these writers. They actually lived in a world of their own. They were poets even in their prose, and the influence of the modern western literary movement was very small.

How can we then analyze this emigration, what was it, and what was its relationship with the tough experience of the moving merchants who lived the experience of strangers, most of them failing in the end their goal of returning and building a house in the land of "return"?

In his book Reflections on Exile, Edward Said speaks about three categories: Emigrants, refugees and exiles. Although he didn't come to create a precise differentiation between these three terms, he tried to introduce his personal experience as a Palestinian writer, as being part of the three categories all at the same time.

Said uses a text by George Steiner in order to formulate his idea about the literary impact of exile:

It seems proper that those who create art in a civilization of quasibarbarism, which had made so many homeless, should themselves be poets unhoused and wanderers across language. Eccentric, aloof, nostalgic [...] (quoted in Said 2001: 174). 
But, unfortunately, he didn't study the literature of emigration, and he would have refused my proposal to read his literary work as a continuation and rupture with this literature.

But on the other hand one can not but read the modern Palestinian literature in the light of the exile experience, and the work of Imil Habīîi (1921-1996) can only be understood in the light of the category of "transcendental homelessness" as defined by Lukács.

The nostalgic aspect became a tragic personal story, as in the case of the death of the poet Rāshid Husayn (1936-1977), burned in his room in New York, or it took poetry to new dimensions where the story becomes the land of struggle and where language is a part of the inheritance of the land, as in the poetry of Mahmūd Darwīsh.

The Mahjarī literature begins its real history, the return to the homeland is achieved through the texts, where it becomes an integral part of the pre-modern movement in both prose and poetry; the only exception to this is the Prophet of Jibrān, travelling through the American religious heritage and becoming part of orientalising the orient, outside the history of literature.

In the thirties of the last century, a new wave of tragic emigration took place, thousands of peasants who immigrated to America through Marseille found themselves in Africa. An experience which related the Lebanese emigrant to the French colonial power and created the shame of Lebanese emigration.

Very little literature was written about these two experiences, one can speak of a small numbers of novels, Sa īd Taqī al-Dīn (19041960) and 'Awaḍ Sha'bān and Imilī Naṣr Allāh (*1938), but the story itself must be told.

Maybe one must change the direction of his investigation and open a new chapter related to literature by Arab emigrants written in Spanish, Portuguese, English and French.

Here one must admit that no real attention has been paid to this literature, as if the Syro-Lebanese communities in the Americas and Africa were dominated by the image of the merchant or the owner of grocery stores and restaurants. Although one must admit that the Lebanese cuisine is the major Lebanese cultural success on the international scene, if not the only one. 
For me, the most interesting part of this conference is to meet some of these writers and to discuss with them their experiences and the possibilities of translating their works to Arabic.

My knowledge is very small, but I will permit myself to point out some moments which created in me the curiosity to know more and the need for the deep communication which only literature can create.

I want to speak a little about the experience of the Lebanese Brazilian writer Raduan Nassar $\left({ }^{* 1935)}\right.$. When Nassar speaks about the language of the family as a strange language, and when he describes the death of his sister Hanne after she came back from church to perform her dance, in his novel An Old Trace, I felt not the nostalgia but the continuation of the struggle for life here or there. Gabriel García Márquez, when he described the death of Santiago Nasar, took me back to the atmosphere of the 1860 civil war, while Raduan Nassar revived in me the image of the Lebanese woman fighting for her human dignity.

I want to quote the poem of the Chilean poet Mahfud Massis (1916-1990):

I think that I am blind

And everything is falling apart

And Palestine is hanging its last dead man on an olive tree

And you Lebanon, how come you became a waste land.

I want to speak about the Argentinean Gregory Mansour, who lives in Paris since 1965, whose novels take us to the Latin American myths, and about Juan José Saer (*1937), the Syrian-Argentinean writer whose work is on the language and a struggle with it. In his novel The Son-in-Law, the Native American character will occupy the scene, and the impact of the Arabic tale will give different versions to the same story.

Writers like David Malouf $\left({ }^{*} 1934\right)$, he is maybe the only one translated to Arabic, need to find impact on their culture of origin, and can help us redefine the concept of World literature as an atmosphere where all the strangers, those who are outside their countries, and those who are strangers in their own countries, can meet and create from the diversities of their languages a human unity. 



\section{Luis Fayad}

\section{Lebanese Migration to the Americas}

When compared with demographic movements throughout the ages, Lebanese migration to the Americas, which began more than a century ago, displays characteristics that distinguish it from migration streams from other countries - be it to this continent or to Europe.

The causes are the same - flight from tyrannical, despotic governments, repressive dictatorships, internal conflicts and desperate economic conditions that offer no prospect of achieving a decent standard of living. The most significant difference between other migrations and the Lebanese exodus was that the emigrants of that epoch left their country with no intention of returning. They bid their homeland a definitive farewell and the links they maintained with their place of origin in the beginning, via letters and personal greetings conveyed by successive waves of emigrants, gradually dwindled and lapsed until they were severed completely.

Once installed in their new home, the emigrants' knowledge of their country was no greater or smaller than that of any resident who reads and listens to items of news relating to strange locations and unfamiliar geography.

The Lebanese immigrants came from all walks of life, ranging from the indigent and desperate to the wealthy and powerful. Some arrived with nothing but the clothes on their backs. Others already had businesses set up and contacts that had been established in European countries. The same diversity was to be found in their levels of culture and education. Some had had little formal instruction; others were well-versed in languages and knowledgeable on foreign cultures and their current affairs and politics - professors and civil servants who were forced to abandon their professions and make a living in trade or business.

The difference between the Lebanese and emigrants from other countries was also evident in the long sea passage that they undertook. Given that it was not unusual for a voyage to last two to three months, passengers had to prepare carefully for the crossing. This was not a 
case of slinging a bag over their shoulder or loading up a beast of burden or tagging along with the first improvised means of transport that presented itself. Preparations for the journey lasted months, sometimes over a year.

Saying goodbye meant farewell forever. Some of those staying behind promised their friends and relatives that they would follow their loved ones at a later date and join them in their new country of residence. Those embarking made no promises to send money back to those remaining behind; that was not the purpose of their journey. They were fleeing their homeland, albeit fleeing in an orderly fashion. Even those people leaving because of the threat posed by foreign invaders had much in common with those emigrants who were going through the proper channels to take formal leave of their country. All arrived on the shores of the Americas united in the newness of their condition, as if they had all planned the same trip together with the same tour operator and with one group leader. Migrants the world over tend largely to travel alone or to fall in with another traveller. The wave of Lebanese emigration a century or more ago was not characterised by any such uniformity of number. Some embarked alone but subsequently hitched up with the group of compatriots they found themselves sailing with. Others planned their voyage in a group of two or three friends. Many emigrants were newly married couples. Other man-and-wife pairs boarded the steamer with one or more children in tow, with a cousin or other relative making up the party for good measure. Yet whether they travelled alone or as a group of friends, as a family unit or in a loosely-knit bunch of like-minded individuals, all were at pains to make the trip with their identity papers in order, valid both in their country of origin and in the country of destination.

After the voyage, the processing formalities on arrival were no great ordeal. The customs authorities, especially those in Central and South America, were quite tolerant. The arrival of people from such a faraway land caused a sensation at first, and precautions were taken on account of the differences between the religious faiths of the respective groups. The new arrivals were soon assimilated, however, both in number and religion. People soon realised that they had come not to ask for alms but to work. Many immigrants possessed some form of start-up capital, however paltry, signifying their intention to invest. There is the story of a man with neither identity papers nor money 
who entered the country secretly, evading the authorities, but there is no record of him committing any felony once this misdemeanour was behind him.

The distant origin of the travellers was soon the talk of the host countries' inhabitants. One had only to mention the Thousand and One Nights and the myths that circulated, spread from person to person in hushed, fantasy-filled tones. And within a short space of time, the religious beliefs of the Lebanese had ceased to be a cause for concern. Not once did the immigrants try to flaunt their religion or use it as a vehicle for spreading their own culture. Those among them who were not Maronites - the religion closest in nature to the Catholicism of the majority of the inhabitants of South and Central America - refrained from practising their particular branch of Islam in public or from setting out to instil their religious tenets in others. In fact, from the second generation onwards, baptisms and marriages were celebrated according to the ecclesiastical rituals imposed by the government of the day. Religious differences posed no hindrance to the Lebanese in their efforts to assimilate into the various countries of the continent.

The registration process at customs was largely free of formalities. Once the processing of the first wave of Lebanese immigrants had gone ahead without problems the authorities in the ports of Latin America dropped their initial wariness. Many new arrivals had some means of supporting themselves, which in turn meant that benefits filtered through to the economies of the host countries. Their identity papers were in order and presented no irregularities to hinder the issuing of residence permits. It was only the travellers themselves who found fault with the registration process: they were from Lebanon and as such compelled to travel on Turkish passports. This was the era of the Ottoman Empire, and Lebanon, which was under its hegemony, was considered a Turkish province. Lebanon as an autonomous entity had ceased to exist.

Neither did language pose even the slightest problem for the swift integration of the new arrivals. Many of the travellers had started taking lessons in the new language even before they made the trip. All of them mastered the rudiments of communication within the first few months, allowing them to cultivate initial relationships with their neighbours. Men especially proved proficient in learning Spanish - or 
Portuguese for those who settled in Brazil. Men were more active in public and their business affairs involved constant communication with people around them. Many of them were also professionals who had brought with them from Lebanon their solid grounding in cultural knowledge. Women tended to learn more slowly as they had less contact with people outside the Lebanese community. It is interesting to note that women learned their first words and basic grammar by interacting with their own domestic employees at home.

The swift integration of the Lebanese with the local inhabitants was also due to the similarity of their customs. Families from both groups had similar structures and conducted themselves in more or less the same way - large families with many children, adherence to the rules of the group, absolute respect for one's elders, religious observance, a friendliness towards and readiness to help others ... Business was conducted in conjunction with social get-togethers. Signatories to a contract were also signing into a friendship. Greetings in the street inevitably led to invitations to this or that home.

The first role of the Lebanese in Central and South America was that of the trader. They became known for their habit of going from house to house and offering their goods for sale. The novelty value of this system secured them a lot of and income. The vendor travelled with one or two suitcases filled with products and sold them on credit, his motto being that they could settle up another day, the important thing being that customers be happy and able to pay without having the impression that they were being charged too much. The vendor left his wares - mostly textiles - with the customer and returned the next day to collect the money. His wares might stem from the domestic market or be imported goods.

An in-depth analysis might well come to the conclusion that of all the things that unite and separate two communities - in this case the Lebanese and the Latin American - food is the most important. Many are the differences in diet and methods of preparation. Just as the Lebanese adapted to the diet of the people around them, so their hosts got used to eating the dishes of the Lebanese, first as friends in their houses, later as patrons in their cafes and restaurants. Not all the ingredients for the dishes could be found in the local shops and markets, however, which led to the springing up of firms dealing in imported 
commodities within the Lebanese community. In the markets, for instance, it was possible to find aubergines and courgettes.

Nowadays people are familiar with the dishes even if they do not eat them regularly. Many dishes are well known in Central and South America: humus, kibbeh, tabboule, warak arish, rice with almonds, mahluta. Preparing the dishes is no longer the preserve of Lebanese women; women from the host community, domestic employees in the homes of Lebanese, learned how to prepare Lebanese dishes, learned other uses for ingredients they were already familiar with and got to know new foods. And now, decades later, many Latin American women - and men - own and operate cafes and restaurants offering every kind of Lebanese cuisine imaginable.

Commerce, the main and almost exclusive occupation of the immigrants, was extended to include other activities. Initially the main new development concerned the sheer volume of textile imports and their distribution throughout the towns, villages and outlying districts. The commercial instincts of the new community knew no bounds. Business conducted with native textile companies came to exceed the expectations of their owners and managers, who were also surprised by the variety of new imported goods. Fine fabrics of all kinds, undercutting the purveyors of more exclusive textiles, gradually became easier to obtain. They came from Lebanon, France and England. Silk, satin, poplin and wool processed using a different method than that familiar to the locals ... all could be seen decking the shop windows and shelves of the new shops.

The business world split into two branches: corporate and industrial. From the first immigrants onwards there were many instances of multiple activities. In Colombia the first riverboat company - and with it a number of important projects organised for the benefit of the shipping companies - were the fruit of Lebanese partnerships, as were the rail companies and firms associated with other means of transport. Commerce, based initially on imports, developed to embrace industry and had soon extended to the export business. Lebanese shops appeared in the main shopping areas of Latin American cities. They were dubbed the "Turkish shops", Turks being the name the locals used for the Lebanese since it was the epoch of the Ottoman Empire and in the countries under its sway the Turkish passport was used. 
The immigrants were not treated as common labourers by the rest of the populace but rather moved in business circles and enjoyed a commensurately high social status. This was in stark contrast to immigrants who arrived as labourers in more highly developed countries and as a consequence were always considered as having a lower status. The social standing enjoyed by the Lebanese meant their children grew up in the bosom of society, as if their families had always belonged to the core founding group, and their relations with other people at school and at work were no different to the relationship between different groups of host-country inhabitants. Whatever label the Lebanese were tagged with - "Turks" or some other name - the appellation implied a certain intimacy and affection and was no different to the nicknames given to any other social group, with no intention of marginalizing it but, rather, akin to a name given to the members of a welcome and sorely needed group of people.

People still remember how some immigrants adapted their Arabic surnames to a phonetic version that more closely approximated the Castilian language, changing the spelling not because the Arab surnames made the Lebanese less acceptable as pillars of society but rather in order to facilitate conversations and so foster personal and professional relations. The role they played in all areas of society was exemplary, given the economic support they provided, their culture and the humane way in which they conducted themselves, working alongside the key leading figures of each country.

Enjoying the support of society as they did, descendants of the Lebanese were able from the first generation onwards to aspire to any type of profession or position in the labour market. Many devoted themselves to following in their parents' footsteps as commercial traders, profiting from their position within the most prosperous occupation in the economies of the continent. Other individuals showed a keen interest in the fields of economics, politics, science, the arts and all areas of culture. The importance of this should not be underestimated. They were given naturalised status from the first generation onwards. The process of obtaining citizenship required only that they had been born in the same town where their parents first made landfall. For them the full range of primary, secondary and higher education, jobs in different technological fields and the entire spectrum of academic careers were within their reach, as easy or difficult for them 
to obtain as for any other person across Latin America. Nothing distinguished them from any other Latin American. They received neither special treatment nor were they at a disadvantage and, consequently, could realistically hope for a career in medicine, engineering, law, politics, the Church or any other field, with all the rights and obligations that such a profession brings with it. A number of presidents of Central and South American countries have been of Lebanese immigrant descent, as have numerous cabinet ministers and parliamentary deputies, ambassadors, diplomats and politicians of every colour. The duties incumbent on people of Lebanese descent and the rights they enjoy are no different from those applying to people of other origins. All are equitable members of the same wider community, with no differentiation made. Colombia was once governed by a president of Lebanese descent, a second-generation immigrant. One of the bestknown guerrilla leaders in the country, working to overturn the government, was also of Lebanese stock. Both were first and foremost Colombians.

Despite the long one-way voyages to Central and South America, the history of emigrants is inextricably linked to that of their native country, and vice-versa. Descendants of Lebanese immigrants began to take a close interest in the history of their parents' and grandparents' homeland, and back in Lebanon people are fully aware of how their compatriots came to want to emigrate, how many indeed made the journey and where they settled. They are disappointed, among other things, that immigrant descendants are unable to speak Arabic, that their links with the Old Country are either non-existent or not as strong as they should be.

Whilst the first emigrants from Lebanon and their offspring born in the host country did not return to the homeland, there were some instances of third-generation Lebanese Latinos returning to Lebanon not to settle in Lebanon but rather for two quite different reasons. Thirty or forty years after the original journey westwards, the older Lebanese began to receive news from Beirut about the death of relatives and the inheritance they were to receive. Their grandchildren then made the trip back to Lebanon to claim the inheritance on behalf of the older generation and at the same time got to know both the land of their grandparents and those relatives who had not taken part in the exodus to the Americas. The second reason for the grandchildren's 
trip to Lebanon was their simple urge to learn about the birthplace of their ancestors.

Trips take the form of a holiday and lead to personal links being forged between relatives born in countries thousands of miles apart and speaking two different languages. These new contacts are sustained through correspondence and subsequent visits. The younger Latin American generations of Lebanese stock are keen to learn Arabic and get to know the history of Lebanon. Lebanese descendants across the continent are increasingly interested in studying the biographies of their ancestors, compiling family trees and communicating the culture of Lebanon to others.

Lebanese migration to Central and South America is a phenomenon that could well serve as the subject of a sociological survey. It is unique in that the immigrants' reception in the host country was much smoother than the effort that preceded the voyage. Moreover, the travellers found it easy to settle into their unfamiliar, adoptive country and were assimilated into society without suffering discrimination. One possible reason for this is that the entire continent of America is a story of multiculturalism. The history of North, Central and South America is both the history of the indigenous inhabitants of the region and the history of Spain, Great Britain, Europe in general, Africa, Arab countries and the whole of Asia. The Americas have been a place where men, women and children from the four corners of the world have met, not only as visitors to the area, but as inhabitants of it. Each American is a participant in the history of every continent of the world. In Colombia there are no Lebanese Colombians, only Colombians in the purest sense of the word. In Peru there are no Japanese Peruvians, only Peruvians. In Argentina one is not an ItalianArgentinean, one is nothing more and nothing less than an Argentinean. Jorge Luis Borges, in his Ulrica, has a woman asking a man: "What does it mean to be Colombian?" To which the man replies: "I don't know. It's an act of faith". His answer could come from the lips of any inhabitant of any country of the Americas when questioned on his nationality.

There is no doubt that Germans and foreigners living in Germany will find the situation of Lebanese emigrants in Latin America strange compared with the situation facing Turks in Germany. The Lebanese and their descendants have no trouble becoming naturalised citizens of 
their adoptive country and enjoying all the rights accruing to citizens. Turks, on the other hand, never stop being Turkish, their integration is never complete, differentiation on grounds of nationality always exists, and this state of affairs shows no sign of changing. One reason for this difference is that in Latin American countries where the composition is so multicultural it is difficult for one person to call another person a foreigner. Secondly it is very important to bear in mind that the Turks moved to Germany as workers, while the Lebanese arrived in Central and South America as traders and businessmen and many of them had money with which to establish a livelihood. The Lebanese have been able to continue in the professions of their most ancient ancestors, the Phoenicians, whose greatest achievement was to spread trade and commerce across Europe. It is said of the Phoenicians that their greatest art consisted in disseminating the arts of others. The Phoenicians founded towns and important trading centres in Europe, fostering a degree of commercial exchange that led inevitably to cultural exchange. These are just two of the dimensions that distinguish the two instances of migration from another. They have to be considered in any political or sociological study of the phenomenon. This is a fascinating subject and is too big to be included in this paper.

The disparities between Lebanese migration and other instances of migration extend to differences in the behaviour of the respective migrants' descendants. It is important to emphasize that immigrant authors do not feel at all obliged - or even inspired - to write about the encounter between two cultures. A Colombian of Lebanese descent, for example, can choose as the theme for a book the same subject that a Colombian of any other extraction might choose. Only one of my novels, La caída de los puntos cardinales, is a story of characters stemming from Lebanon. In my other novels there may or may not be characters of Lebanese extraction, but the main figures all come from the immediate vicinity depicted in the book. No reference is made to any immigration; the books' themes and the private issues depicted within them are the universal themes and issues that people must confront regardless of their nationality. By the same token, writers of nonLebanese provenance include in their stories characters that are of Lebanese extraction; these characters are part and parcel of society and are viewed neither as being the progeny of immigrants nor as being in any way less integrated into the fabric of society. The extent 
to which one feels - and is - Colombian is the same whether one is an indigenous American, an African American or a person of Spanish, Italian or Lebanese descent. In the writing of the book none of these factors is relevant in any folkloric sense. In my novels and short stories I can concentrate on describing life in Colombia without having to include characters of Lebanese descent and without having to tackle issues of integration.

Descendants of the Lebanese find it easier to write about Lebanese immigration since they know stories and family details that do not feature in the history books. Yet they still encounter the same difficulties as writers who are not of Lebanese extraction. This has been my experience. In order to increase my knowledge of life in Lebanon and write my novel La caída de los puntos cardinales, I spent time talking with immigrants who had recently arrived from Lebanon and were settling in Europe. They completed my knowledge of Lebanese customs and the relations between religious communities. I also came to understand why and at what point these good relations might begin to deteriorate, and also the reasons these people had for leaving their homeland. Each individual's story drew me into the realms that I needed to enter if I was to write with authority on my characters, on the issues facing them and on the Arabic language. I started learning Arabic so as to be able to colour my own language with the kind of Arabic inflections and colloquialisms that would feature in the dealings my characters had with each other. During the private and professional trips I made to Colombia and via correspondence I managed to get access to a lot of documents including birth certificates, marriage certificates and death certificates. I had a lot of conversations face-to-face with people and over the telephone in which I refreshed my memory and clarified references to money, precious metals and other accoutrements that emigrants had brought with them. When I was a child in Colombia, on visiting the homes of Lebanese families one still saw artefacts that reflected the purchasing power of the family concerned, objects such as gold coins, hookahs, caps and canes.

I researched the history of Colombia, the key junctures in the changing course of events and the reasons for its inability to transform itself swiftly when the occasion demanded for it. I revised my geography and studied the means of transportation available to successive generations and eras and on port activities along the Atlantic coast. I 
read up on the conditions endured during sea passages from the East and from Europe to our Continent, on the customs procedures at the ports of entry and the prerequisites that prospective immigrants were required to fulfil. By reading and observing I was able to fill the gaps in my real experience that had opened up since childhood. It was a learning process that coincided with the inspiration I needed in order to be able to reproduce the information in an organic fashion, not as one who knows, but as one who feels. Without realising it, I had been writing this novel ever since I was a child. I say this because descendants of the Lebanese have a strong sentimental link to Lebanon, even though the link is not a conscious one. Everyone develops this sentimental attachment sooner or later; a desire is awoken to visit Lebanon, to learn Arabic, to enter another world. And the descendants of Lebanese immigrants come to acquire a faculty for broadening their sympathies and understanding how to embrace two separate worlds. 



\section{Lisa Suhair Majaj \\ New Directions: Arab American Writing Today ${ }^{1}$}

Arab American literature has gone through many shifts since the early decades of the twentieth century, when Khalil Gibran and other Mahjar writers in New York formed Ar-Rabitah, the Writer's Guild, and began to publish poetry and prose that changed the face of Arabic literature even as it initiated a century of Arab American literary endeavors throughout the Americas. But in many ways the issues that confronted the Mahjar writers continue to confront Arab American writers today. Whether or not contemporary writers struggle with the Mahjar writer's dilemma of which language to write in (for many the choice is not theirs to make) they, like their predecessors, inhabit multiple cultures and write for multiple audiences: American, Arab, Arab American. And despite the growing consolidation and visibility of the identity "Arab American", this negotiation of cultures has often resulted in a form of split vision. Like other hyphenated individuals, Arab Americans seek to integrate the different facets of their identities, experiences, and heritages into a unified whole. But too often there remains a schism between Arab and American, east and west. Authors turn one eye to their local context while keeping the other eye on the Arab context of origin. But in the process of turning the gaze in two directions at once, what is sometimes overlooked is the ground beneath their feet.

Although the Arab American experience in both Northern and Southern American contexts has come to greater visibility in the past several decades, providing far greater space and support for Arab American articulation than was previously the case, the conflicts which confronted the early Mahjar writers continue to inform current literary and cultural expression. In this essay, I focus on U.S. Arab American writing, a literature which has largely been produced in

1 This is an update of Majaj (1999). 
English. The U.S. experience is of course but one facet of Arab American experience as it is played out in North and South American contexts, languages and cultures, and a full investigation of the points of contact between "Arab" and "American", although beyond the scope of this essay, must inevitably move beyond the limitations of the U.S. sphere. The workshop ArabAmericas, Transatlantisch (Berlin, June 16-17, 2005) provided an excellent starting point for such a discussion. I am particularly grateful to Professor Ottmar Ette for his insistence that the term "Arab American" be broadened to encompass both North and South America, and that the fallacy of using the term to refer only to the U.S. context be made explicit.

The sense of split vision which has so often informed U.S. Arab American literature has typically been expressed as a tilt toward one side of the hyphen or the other. Although the New York school of Mahjar writers were influenced by their American literary and social contexts in ways which have not been fully explored, they were nonetheless primarily expatriate writers: exiles who wrote largely in Arabic and whose vision and attention were largely directed toward the Middle East and its literary and political contexts. On the other hand, immigrant autobiographers writing in English sought to orient and ground themselves within the U.S. context by drawing on the conventions of American immigrant autobiography, claiming their credentials as U.S. citizens and virtually writing themselves into existence as Americans. In texts such as Abraham Mitrie Rihbany's 1914 autobiography A Far Journey (Rihbany 1914) and Salom Rizk’s 1943 autobiography Syrian Yankee (Rizk 1943), for instance, Arab identity is mediated through strategies of containment and distancing and situated within a broad claim to American identity. Such focus on Americanization was a natural result of early nineteenth century xenophobia, the restrictions on immigration to the U.S., and various tensions over who was to be included in the definition "American." Indeed, a series of legal cases in the second decade of the $20^{\text {th }}$ century questioning the "whiteness" of Arab immigrants and hence their eligibility for American citizenship, helped set the stage for this anxiety about American 
identity - an anxiety which was to leave a distinctive mark on Arab American writing. ${ }^{2}$

In the late 1960s and 1970s, however, the emergence in the U.S. of a pan-ethnic Arab American identity bridging different national and religious backgrounds helped set the stage for a new kind of literature affirming and engaging Arab and Arab American identity. Situating this emergence of Arab American identity on both literary and cultural levels were a number of events. First, the Civil Rights and Black Power movements of the 1960s and the ethnic "roots" phenomenon which gained ground in the 1970s provided the foundation for affirmation of multiculturalism in the U.S. and opened new spaces for the so-called hyphenated genres of American literature: African-American, Asian-American, Jewish-American, Italian-American and others. The arrival of more educated, politicized Arab immigrants after 1960, including greater numbers of Muslims, spurred settled Arab Americans to a new engagement with their cultural identities. At the same time, the establishment after 1967 of an institutional framework for Arab American life through national organizations such as the American-Arab Anti-Discrimination Committee (ADC), the Association of Arab-American University Graduates (AAUG), and the Arab American Institute (AAI) helped to encourage ethnic pride as well as pan ethnic identification. ${ }^{3}$ And finally, the impact of wars and other political events (including the 1967 Arab-Israeli war, the Lebanese civil war, the Israeli invasions of Lebanon, the two Gulf Wars, the oil embargoes of the 1970s and hijackings and bombings in the 1980s and 1990s, the destruction of the World Trade Center on Sept. 11, 2001) have forced Arab Americans to grapple with their identity and with the "write or be written" imperative: Define yourself or others will define you.

The poetry and prose published in the U.S. from the late 1960s onward by Arab American authors engaged increasingly with issues of

2 For a discussion of these legal cases and their implications for literature, see Majaj (2000).

3 The institutional life of Arab American has in recent years expanded into the cultural sphere. Examples include the Arab American Museum in Detroit, Michigan; publications such as Mizna: Prose, Poetry and Art Exploring Arab America and Al Jadid: A Review and Record of Arab Culture and Arts; and literary organizations such as RAWI: Radius of Arab American Writers and the Arab American theatre collective Nibras. 
ethnic and cultural identity. But for many years this writing was limited and hard to find, and remained largely unrecognized as a body of literature. Until the late 1980s it was not even possible to search under the category "Arab American literature" in U.S. libraries: there was no such classification. Things began to change with the publication in 1988 of Gregory Orfalea and Sharif Elmusa's groundbreaking anthology Grape Leaves: A Century of Arab American Poetry (Orfalea/Elmusa 1988) - a collection spanning the Mahjar period to the late 1980s which quite literally put Arab American literature on the map. Since then, Arab American literary anthologies have seen a relative proliferation: subsequent collections have included Joanna Kadi's 1994 collection Food for our Grandmothers: Writings by Arab-American and Arab-Canadian Feminists (Kadi 1994), Khaled Mattawa and Munir Akash's 1999 Post Gibran: Anthology of New Arab American Writing (Mattawa/Akash 1999), Pauline Kaldas and Mattawa's Dinarzad's Children: An Anthology of Contemporary Arab American Fiction (Kaldas/Mattawa 2004b), and forthcoming anthologies under preparation. ${ }^{4}$ There have also been several collections which have linked Arab and Arab American literature: notably Naomi Shihab Nye's The Space Between Our Footsteps: Poems and Paintings from the Middle East (Nye 1998) and Nathalie Handal's The Poetry of Arab Women (Handal 2001). Meanwhile, of course, the number of individual author's texts has grown precipitously. Once largely invisible, Arab American literature is on its way to becoming a recognized subgenre of American ethnic literature.

Yet the split context within which Arab American literature emerged - a focus on cultural affirmation in the American context on the one hand, and attention to political events and events in the countries of origin on the other hand - continues to shape this writing not only in theme but also, perhaps, in form. The fact that Arab American literary production has until recently leaned heavily toward poetry has often been noted. Although at the moment we are seeing a surge of fiction and memoirs as well as forays into relatively new genres, as drama and comedy, poetry remains the predominant Arab American literary genre. The usual, somewhat essentialist explanation put forward for this dominance has been that Arabs have an intrinsic cultural

4 See Handal (forthcoming) and Charara (forthcoming). 
propensity towards poetry. Indeed, in the preface to Grape Leaves, the editors quote the eleventh century scholar and critic Ibn Rishiq: "The ancient Arabs wish one another joy but for three things - the birth of a boy, the coming to light of a poet, and the foaling of a noble mare" (Orfalea/Elmusa 1988: xv). In other words, it is suggested, as a group Arab Americans have produced more poetry than prose because poetry is somehow "in our blood". This intrinsic link to poetry is often claimed even when the writers in question do not read Arabic and have no direct relationship to the tradition of Arabic poetry.

Another explanation sometimes put forward is more sociological in focus: that U.S. Arab American writers have produced more poetry than prose because, as a small and beleaguered ethnic group, writers have only recently begun to feel established enough to turn to serious literary endeavors and have not, therefore, set in place for themselves the kind of support systems, both economic and social, needed for the writing of fiction. It is arguably true that as a genre, book-length fiction may demand a more extended focus than poetry, and that publishing novels is more difficult than publishing individual poems (although not harder than publishing books of poetry). However, despite the particular problems confronting the novel writer, this theory does not explain why Arab Americans as a group have until recently produced not only so few novels, but also so little short fiction as well.

There is another possible explanation, however, one connected to the ways in which U.S. Arab American culture has been shaped by the historical legacy of split vision. Arab Americans have traditionally focused on poetry, it might be argued, because poetry is the genre best suited to their experiences of celebration and mourning, affirmation and loss. Throughout the twentieth century Arab Americans have been situated between an ethnicity defined through intense familial and communal relationships and an equally intense (if often unwilled) engagement with political events. These dual orientations are linked by the literary genre typically used to articulate intense emotion: that of the lyric. Defined as a poem that expresses the feelings and thoughts of a single speaker, the lyric as a literary mode is particularly effective in articulating moments of intensity and illumination. It provides a ready vehicle not only for nostalgic celebrations of family and community, but also for anguished depictions of war and suffering, both of which have played such large roles in Arab American experience. 
What the lyric mode does less well, though, is to provide a broader forum for representation, analysis, discussion and critique. Its poetic compression favors vignettes rather than narratives, moments of insight over sustained analysis; as a result it tends to evoke rather than explain. The predominance of the lyric mode in Arab American literature might therefore suggest a group focus on self assertion and expression rather than internal analysis and critique. After all, only after the self - personal and communal - has been established as a presence can it be examined and questioned.

Given the U.S. Arab American history of invisibility, exclusion and stereotyping, as well as the repercussions of war and occupation in Arab lands, it is no surprise that writers have felt the need to assert identity and mourn the ravages of political events. But as a genre, poetry, while powerful and eloquent, has not always provided an adequate forum within which to probe the full complexity of Arab American experience. As Arab American identity has become increasingly visible on the U.S. landscape, simply to be an Arab American is not an anomaly anymore. As a result, Arab American writers confront the need not just to assert their presence, but also to explore, question and critique their own identities and relationships with others. At the beginning of the $21^{\text {st }}$ century, perhaps what is most needed is not just an examination of who Arab Americans are and where we have come from, but an exploration of where we are going and who we hope to become.

In the introduction to their anthology of short fiction, Dinarzad's Children, Pauline Kaldas and Khaled Mattawa link this issue of form to representational tensions. The lyric poem, they note, afforded Arab Americans
a way to speak as individuals to individuals, and a way to affirm that they were speaking for themselves even when their poems contained the con- cerns of multitudes around the world [...] [but] in shying away from fic- tion and prose narrative in general, Arab American writers may have wished to exert greater control over the representation of their commu- nity (Kaldas/Mattawa 2004a: xi).

Indeed, there has been a certain reluctance among Arab Americans in general to openly discuss issues which may reinforce prevailing negative stereotypes of Arabs. Given the political and social pressures facing Arab Americans in the U.S., writers may feel, and readers may 
expect, that their task is to affirm Arab identity and to translate this identity to outsiders, not to lay bare divisive or problematic themes for the scrutiny of others.

Since the original writing of this essay, there has been much debate within the U.S. Arab American community on the need to move beyond both nostalgia and the reactiveness generated by political pressures (greatly accentuated in the post 9-11 context) toward a more critical, reflective, creative and transformative engagement with the many strands of Arab American experience (including the Arab cultural and literary heritage, which is paid lip service to by many but rarely explored in any depth). Mattawa has addressed this issue with particular directness and fruitfulness. In his essay "Arab American Writing and the Challenge of Reinventing Tradition”, Mattawa notes that Arab American literature largely emerged as a "survival mode of writing" (Mattawa 2003: 16) in which authors write out of a sense of political and ethnic crisis. Yet in confronting the existential need to assert their humanity in the face of a culture that dehumanizes them on ethnic, racial and political grounds, at the same time as they mourn a receding old-world culture, Arab American writers run the risk of becoming trapped within a Manichean formula: one which pits a dehumanized American present against a nostalgic, romanticized Arab past. Not only is the schism a reductionist one, the role of victim allows a writer room for little except bemoaning their fate. The result of such alienation, Mattawa correctly argues, is a sort of cultural protectiveness which leads to "philosophical and ethical vagueness":

We fear airing our dirty laundry because we fear the very likely possibility of that information being used against us. So we have not taken on our communities - and the materialistic and spiritual depravity that can be witnessed throughout our so-called events and festivals [...]. And so many of our flawed cultural practices have not been confronted - the rampant misogyny and chauvinism that still define masculinity in our subculture, the forced marriages, and racism, particularly the problematic role Arab-American entrepreneurs have played as middle men between American corporate capital and America's downtrodden (Mattawa 2003: 16).

To move away from defensive nostalgia and stereotypical "ethnic" themes, however, toward more intellectually and thematically daring material, arguably requires an expansion not just of theme but also of literary style and genre. As Mattawa and Akash point out in their introduction to Post Gibran, "Changes in form [...] are important signi- 
fiers of changes in subject matter and in tactics" (Mattawa/Akash 1999a: xiii). Conversely, different literary genres make possible different kinds of conversations. It is noticeable, for instance, that the emergence of a body of feminist Arab American writing, as well as growing attention to issues of race and class, corresponds with a shift toward prose writing, both fiction and nonfiction. Overall, it is as if to move beyond simple celebration toward more rigorous and selfcritical explorations mandates a move away from the lyric compression of poetry toward the more expansive and explanatory medium of prose.

Hand in hand with this move toward different genres and themes has come a small increase in critical writing about Arab American literature. Critical discussion is necessary for several reasons. For one thing, a literature which is not critically analyzed possesses less stature and visibility in the literary world: its texts will be less well known and less likely to be read outside the local community. Critical discussion also helps to make visible the kinds of literary and cultural traditions upon which Arab American writers draw: this discussion is useful not only for readers (and teachers) but also for writers. And while criticism has a crucial role to play in highlighting not just the cultural and sociological, but also the literary dimension of Arab American writing, a body of informed and nuanced literary criticism could play a significant role in situating Arab American literature for both Arab and non-Arab readers, lessening somewhat the pressure on Arab American writers to serve as "translators" and guardians of their culture.

The 1999 version of this essay concluded by outlining some areas in which I thought U.S. Arab American literature could productively move. Although we have made progress in the last few years, there is still a substantial way to go, and these areas remain important ones for Arab American writers. I therefore believe it is not out of place to outline these areas again:

1. We need to continue to move away from simple nostalgia and toward a more direct confrontation with the Arab American past. This is not to deny the importance of cultural, communal and personal affirmation, especially in the current political climate. Rather, it is a call for greater complexity. U.S. Arab American 
history is not limited to upward mobility on the one hand (the classic American success story favored in most of the community's autobiographies) and cultural loss on the other (the underside of assimilation). Nor can Arab American experience be adequately portrayed through a simplistic cultural celebration that centers upon food and dance (the hummus-and-tabouleh version of ethnicity). Rather, the experiences of Arab Americans in the U.S. have been at once more complex and more painful than any of these narratives suggest. One task confronting Arab American writers is that of exploring not just ethnic celebration and entry into white middle class America, but marginalization, poverty and exclusion - not only in the broader American society but within Arab communities as well. (The latter project remains particularly unvoiced to date. For instance, as Mattawa has noted, the true subalterns in the Arab American community are the Yemeni migrants - a group that remains practically invisible in discussions about the Arab American community.)

2. We need more attention to the ways in which U.S. Arab Americans have been racialized in the American context. For too long Arab Americans have tried to escape into white ethnicity, a flight made more possible by legal definitions of Arabs in the U.S. as "white." But history has shown, time and again, that this formal status of "whiteness" is merely honorary and is quickly revoked in the wake of political events in the Middle East as well as in the U.S. Not only would Arab Americans do well to grapple with the implications of this racialization, we would also do well to explore the ways in which it provides new grounds for solidarity with other groups of color. ${ }^{5}$

3. We need a stronger, more nuanced and less defensive articulation of feminism. Arab American feminist critique has traditionally been hampered by the overwhelming array of orientalist stereotypes about Arab culture at play in U.S. contexts. When Arab and Arab American women give voice to feminist concerns, they are too often assumed, both by their own communities and by outside

5 This call for acknowledging Arab American racialization and forging connections with other communities of color has increasingly been raised in recent years. Of particular note is the forthcoming collection Jamal/Naber (under review). 
observers, to be rejecting their own cultural traditions in favor of a more "liberated" western culture. Depending on the stance of the observer, this is viewed either as an escape or as a betrayal. The result of such over-determined discourse has often been a pressure toward silence, with accompanying community censure of those writers who do attempt to publicly explore more problematic aspects of Arab and Arab American culture. As Arab American writing is read by a widening audience of readers with no prior knowledge of Arab culture, such representational difficulties multiply. Yet to succumb to silence in order to escape being misunderstood is in its own way a form of self-betrayal. What Arab Americans need is not less but more representation - for only when there is a wide array of depictions of Arab American experience and culture will writing that is self-critical be understood for what it is: an effort at self-transformation. ${ }^{6}$

4. We need more social criticism in general. Although U.S. Arab Americans have often liked to celebrate their law-abiding record, strong family structures and so on, we confront, as much as any other community, internal problems linked both to our Arab and our American identities and contexts. Arab Americans are not free of domestic violence, drug use, gang participation, and so-called "honor killings". All too often racism, sexism, classism and especially homophobia go unquestioned. While literary texts are not social exposés, they nonetheless provide a forum within which social questions may be probed: this role should not be forgotten or ignored.

5. We need to take a closer look at the complexity of Arab American identity. To identify simply as Arabs in the U.S. or as Americans of Arab heritage is in some ways to gloss over this complexity: although both identities are accurate, Arab Americans are also engaged in the process of ethnogenesis - the creation of a new culture drawing on both past and present contexts. The legacy of split vision, of being torn between the Middle East and the U.S., has had direct and pragmatic impact on the evolution of this identity. But Arab American authors do not simply write Arab literature in

6 For a recent publication which grapples with issues of Arab American feminism, see Abdulhadi/Naber/Alsultany (2005). 
English (as was once suggested to me): they do not simply translate from culture to culture. Arab American literary works need to explore ethnicity as something altogether new: something that is in the process of creation.

6. We need to pay more attention to who is excluded by existing definitions. Does Arab American literature reflect the diversity of Arab American experience and identification? When we talk about Arab Americans, are we including people of mixed heritage, religious and racial as well as national? Are we including Arab Jews who identify with their Arabness? Are we including those who don't know any Arabic? Those originating from Arab countries aside from the common origin points of Lebanon, Syria, Palestine, Iraq? And perhaps most importantly, are we including homosexual Arab Americans, whose experience has been for all practical purposes silenced in discussions of both Arab and Arab American culture? Although the emergence on the literary scene of a number of openly gay-identified writers has begun to challenge the silencing of alternative sexual identities in Arab American cultural life, there is still scant room for such voices. ${ }^{7}$

7. We need to continue to infuse our work with new cultural forms and genres, to become more self-conscious about the diverse cultural traditions within which we are writing, Arab and American, and to turn more consciously to literary experimentation. For instance, rap music and hip hop are clear influences on the work of some younger Arab American poets. Similarly, a few writers are fruitfully mining the relationship with Arabic language, experimenting with bilingualism, in much the way Latino/a writers have done, and exploring happens when Arabic enters Arab American writing, both on a linguistic and a visual level. Such experimentation is vital, because it helps Arab American writers connect to the richness of both their past and their present.

8. We need to keep in mind our multiple audiences without being stymied by them. When we write and publish, we speak both to and for Arab Americans. But we also address readers within and without our many other communities - national, gendered, cultur-

7 One important resource on gay Arab life is the internet publication Bint el Nas, found at <http://www.bintelnas.org $>$. 
al, political and literary. Consciousness of this diverse readership can have a significant impact on how and what Arab Americans write. While the pressure to represent Arab culture in a positive light can have significant impact on the willingness to be selfcritical, we need to remember that literary and activist concerns are interrelated but not identical.

9. At the same time, however, we need to acknowledge our implicit activist role. Writers writing fluently in English have a chance to reach broader audiences than translations ever could. We need texts that will translate Arab political and social realities into human terms and that will create a space for empathy on the part of readers who might otherwise remain indifferent. Given the depth of ignorance and misinformation about the Arab world, we are particularly in need of narrative prose - writing that is capacious enough in form to convey fact as well as emotion. An example might be historically-grounded novels capable of narrating Arab realities to American readers without sacrificing literary quality to didacticism that will tell a compelling but also informative story.

10. We need more children's literature that portrays the Middle East in human terms and more children's literature depicting Arab American experiences. Children and young people in the U.S. are barraged with negative images of Arabs by way of comic books, cartoons, movies and even textbooks. Until recently there has been little literature geared at younger readers that could offset these images, although Naomi Shihab Nye's publications have been groundbreaking. In addition to portraying Arab Americans and the Arab world in non-stereotypical ways, children's literature also offers exciting possibilities for collaboration between writers and visual artists, collaborations that might lead to other kinds of aesthetic experiments and innovations.

11. And finally, we need to reclaim the personal. As Arab Americans we have many concerns, and not all of them can be contained within the rubric of the communal. While Arab American identification has had a huge impact on us, we need to recognize the ways in which the personal dimensions of our experience can also illuminate our understanding of communal concerns. Our lives are inflected and informed by ethnicity, but not limited by it. In segregating those aspects of our lives which do not seem "Arab” from 
our definition of Arab American identity, as we so often do, we diminish both our writing and ourselves.

Although the post 9-11 period puts Arab Americans under renewed pressure to assert their identities, I believe that our task nonetheless remains that of expanding and transforming ethnic boundaries and definitions. In broadening and deepening our understanding of ethnicity we are not abandoning Arab or Arab American identity and experience, but making room for the complexity of our experiences. To shift focus from preservation to transformation is not to dilute Arab American identity, but to make it more viable. At the beginning of the $21^{\text {st }}$ century, the split vision we have possessed since our arrival in the Americas may be our most important legacy, forcing us to direct our gaze not only backwards to the past, but forward to a future we are engaged in writing ourselves - and to do so with our feet planted firmly on the Arab American ground beneath our feet.

\section{Bibliography}

Abdulhadi, Rabab/Naber, Nadine/Alsultany, Evelyn (2005) (eds.): “Gender, Nation and Belonging: Arab and Arab American Feminist Perspectives”. The MIT Electronic Journal of Middle East Studies 5; <http://web.mit.edu/cis/www/ mitejmes/>.

Charara, Hayan (forthcoming) (ed.): Contemporary Arab American Poetry.

Handal, Nathalie (2001) (ed.): The Poetry of Arab Women: A Contemporary Anthology. New York/Northampton: Interlink Books.

- (forthcoming) (ed.): Arab American and Anglophone Arab Literature: An Anthology. New York/Northampton: Interlink Books.

Jamal, Amaney/Naber, Nadine (under review) (eds.): From Invisible Citizen to Visible Subject: Arab Americans and "Race" before and after September $11^{\text {th }}$. Syracuse: Syracuse University Press.

Kadi, Joanna (1994) (ed.): Food for our Grandmothers: Writings by Arab-American and Arab-Canadian Feminists. Boston: South End Press.

Kaldas, Pauline/Mattawa, Khaled (2004a): “Introduction”. In: Kaldas, Pauline/Mattawa, Khaled (2004) (eds.): Dinarzad's Children: An Anthology of Contemporary Arab American Fiction. Fayetteville: University of Arkansas Press, pp. ixxiv.

- (2004b) (eds.): Dinarzad's Children: An Anthology of Contemporary Arab American Fiction. Fayetteville: University of Arkansas Press. 
Majaj, Lisa Suhair (1999): “New Directions: Arab-American Writing At Century’s End”. In: Mattawa, Khaled/Akash, Munir (eds.): Post Gibran: Anthology of New Arab American Writing. Syracuse: Syracuse University Press, pp. 67-82.

- (2000): "Arab Americans and the Meanings of Race”. In: Singh, Amritjit/ Schmidt, Peter (eds.): Postcolonial Theory and the United States. Oxford: University of Mississippi Press, pp. 320-337.

Mattawa, Khaled (2003): “Arab American Writing and the Challenge of Reinventing Tradition”. In: Flyway: A Literary Review 7.2-7.3 (“Arab American Writing”. Guest Editor Joe Geha), p. 16.

Mattawa, Khaled/Akash, Munir (1999a): “Introduction”. In: Mattawa, Khaled/Akash, Munir (1999b) (eds.): Post Gibran: Anthology of New Arab American Writing. Syracuse: Syracuse University Press, pp. xi-xiii.

- (1999b) (eds.): Post Gibran: Anthology of New Arab American Writing. Syracuse: Syracuse University Press.

Nye, Naomi Shihab (1998): The Space Between Our Footsteps: Poems and Paintings from the Middle East. New York: Simon and Schuster.

Orfalea, Gregory/Elmusa, Sharif (1988) (eds.): Grape Leaves: A Century of Arab American Poetry. Salt Lake City: University of Utah Press.

Rihbany, Abraham Mitrie (1914): A Far Journey. Boston: Houghton Mifflin.

Rizk, Salom (1943): Syrian Yankee. Garden City, N.Y.: Doubleday. 


\section{Nathalie Handal \\ Our Roots in the Mezze: The Politics of Food and Arab-American Women Poets}

"We only saw it from a distance [her Arabic heritage]", Helen Hatab
Samhan explains. "It was all very foreign to us". It’s true that Helen's ex-
tended family maintained close ties and that her mother continued to
cook Syrian food. But that was it (Shakir 1997: 95).

It is not a surprise that the two pioneering anthologies of Arab-American literature make a reference to food in their titles - Grape Leaves: A Century of Arab-American Poetry edited by Gregory Orfalea and Sharif Elmusa and Food for Our Grandmothers edited by Joanna Kadi - for food has played a key role in the preservation and dissemination of Arab culture. Food is not only about biological nourishment and writing about food is not only about gastronomic history. Rather, food demonstrates the historical, cultural, social and political developments of any given group: "Food is life, and life can be studied and understood through food” (Counihan/Van Esterik 1997a: 1).

Critics from numerous disciplines have come to acknowledge culinary history and texts as an important gateway into cultural and social consciousness. The anthropologist Sidney Mintz said that "Food is such a powerful dimension of our consciousness as living things" (Sonnenfeld 1999: xv) that we must study it to better understand human behavior, and I would add cultural behavior. There is an important relationship between food and literature in all cultures. This relationship can be found in nonfiction or fiction works, from the Greek Middle Ages with Homer's poems (The Iliad, pp. 457-476) and the Greek "symposium", the Latin "convivium”, Arabic popular narratives and proverbs, all genres of Arabic literature, James Joyce's Ulysses, novels by François Rabelais, Virginia Woolf, Giuseppe Tomasi di Lampedusa, Primo Levi, Italo Calvino, Marguerite Duras, Marguerite Yourcenar, Francis Hayes's "Under the Tuscan Sun", the poetry of Giacomo Leopardi to contemporary ethnic American literature. Culi- 
nary studies and gastronomic histories are increasing and becoming more respected in the academic world. However, there is not much written about food, feminism and Arab-American women's literature. In this essay, I will demonstrate the different notions of food in ArabAmerican culture through the textual richness of Arab-American women's writings. The essay starts with a brief look at citations of food in various texts by Arabs or about the Arab world. It looks at the role food and eating have played in the Arab world, in order to understand the culture and better comprehend the role food has played in the formation of an Arab-American identity. The essay then focuses on Arab-American women writers and the representation and meanings of food in their works. They describe the way food is prepared and served in Arab-American homes, but also use food to convey historical incidents, make political, social and cultural statements, portray Arab-American life and experiences, express meanings and emotions, tell stories, and act as cultural agents and agents of resistance. For these women writers, food is an identity definer. The essay argues that food has been one of the most powerful cultural transmitters leading Arab-Americans to their roots, and through food they have preserved their roots. When observing Arab communities in the United States, Latin and South America, food is the leading cultural component, the one that has predominately survived.

\title{
1. The Politics of Food Culture and the Arab World
}

\author{
Lebanon is everywhere \\ in the house: in the kitchen \\ of steaming pots, leg of lamb \\ in the oven, plates of kousa, \\ hushwee rolled in cabbage, \\ dishes of olives, tomatoes, onions, \\ roasted chicken, and sweets [...] (Joseph 1988: 27).
}

Food culture and writings about food go back to the earliest civilizations and much can be learned from kitchens. Lynne L. Gelber exclaims that, "food was likely the cause of the rise and demise of most cultures" (Gelber 1989: 159). There are numerous texts concerning food - history books, poetry collections and folk literature, cookbooks, geography books, and it is worth mentioning some of them to show the presence of food on the printed page in the Arab world, and 
in books written about the Arab world throughout history. Samuel Kramer suggested that

the first civilization to invent an alphabet, Sumer, arose because of the need for fertile land on which to grow barley, the staple of the Sumerians' paste, bread, and beer. And these people provided the first writing on food, a Farmer's Almanac (Gelber 1989: 159).

There were two manuscripts from the Abbasid period that Maxime Rodinson studied in his "Recherches sur les documents arabes relatifs à la cuisine” (1949) and both were entitled Kitab al-Tabikh. The first one was

by Muhammad b. Hasan al-Baghdadi (d 1239; 1934), the second by Ibn Sayyar al-Warraq $\left(10^{\text {th }}\right.$ century; 1987), and a later one (in several variant versions), Kitab al-Wusla ila'l-Habib, of uncertain authorship, but probably by a $13^{\text {th }}$ century Ayyubid prince in Syria, [and these] form the extant canon of cookery literature for the medieval Eastern Muslim world (Zubaida/Tapper 1994a: 3-4).

Geer Jan Van Gelder's Of Dishes and Discourse looks at Arab-Islamic culinary culture and how it is depicted in Arabic literature. This study confirms the significant presence of food in literature. In the chapter entitled "Adab or the Text of Banquet", Geer Jan Van Gelder explores the representation of food in the works of al-Jahiz, al-Zamakhshari, al-Ibshihi, al-Tanukhi, among others. There are also writings about food in travel accounts of different periods, such as the writings of the explorer and scholar Richard Burton (1821-1890). Through Burton's chronicle of dining in Mecca (1855) we find out what Arabs ate, with what ingredients these dishes were prepared, and the dining manners of the Arabs. For example, we learn that it was not "customary, in these lands, to sit together after dinner - the evening prayer cuts short the séance [...]” (Burton 2000: 66). In Egypt,

The discovery at Saqqara, at the funeral well of the tomb of a Second Dynasty woman (c.3700 B.C.E.), of a number of plates bearing assorted foods has provided a valuable source of information on eating preferences and food preparation during that early period. [And again a] great deal of information can be derived from the menu of a dinner prepared for a Nineteenth Dynasty pharaoh and his extensive retinue during an official visit (Bresciani 1999: 38-39).

There were many ingredients then that are still found today in the Arab menu, for instance, meats, fishes, ordinary and oasis grapes, dates, chickpeas, lentils, broad beans, figs, honey, breads, cucumbers, 
different oils and beverages such as "Syrian beer, Palestinian wine [...]" (Bresciani 1999: 39). Of course, these are the basics and are prepared differently in every region of the Arab world; nonetheless, these ingredients encompass an essential part of what is referred to presently as Arabic food. Through food we get information about the agricultural sector at different periods of time. We come to know more about the variety of products that existed and the openness in the region since many products were exported, such as the "Cyprus oil, from the country of the Hittites, nekefeter oil from Babylon, oils from Amor, Syria, and Naharina” (Bresciani 1999: 39). Many of the foods mentioned above are part of the Mediterranean diet, more specifically in the land of Canaan. ${ }^{1}$ Today, we refer to that region as Syria-Palestine and the western Phoenician world. In addition to the foods mentioned above, some others include cereal, barley, wheat, eggplant from this part of the Mediterranean region, which are common in contemporary Arab cuisine. We can assume, given the Arabic tradition today, that gathering for meals was a ceremony. In any contemporary Arab household, food and eating is about coming together; holding on to the food of their ancestors is a spiritual act and culturally symbolic, it is a strong portrayal of family traditions. Arabs consider eating together as Plutarch described it to be: "We do not sit at table only to eat [...] but to eat together" (Montanari 1999a: 69). It is a ritual, an expression of the past, of history, of diverse mixing of cultures and togetherness. Arab immigrants consider that if their children and grandchildren eat Arabic food and like it, this confirms that they have embraced their roots and that they belong to that civilization and honor it. In a small society food "is understood to be the product of the labor of known

1 The land of Canaan is "[...] the geographical area that became Phoenicia at the beginning of the Iron Age, [which] was originally occupied by the Canaanites, a group of Semitic origin. During the third and second millennia B.C.E., it was divided into small city-states with close political and cultural links to the great powers of Syria, Mesopotamia, and Egypt.

In the twelfth century B.C.E., political equilibrium in the Near East was disturbed by a progressive deterioration in social and economic organization and the migratory flows of large numbers of groups known as the Peoples of the Sea. As a result, the land of Canaan broke up into a number of nation-states, including Phoenicia [...].

The Phoenician people occupied a narrow strip of territory between the sea and the Lebanon and Anti-Lebanon mountain ranges, where the land available for cultivation was limited but fertile” (Giammellaro 1999: 55). 
individuals, the output of their blood, their sweat, their tears" (Meigs 1997: 104-105). For Arab-Americans, food is a symbol of their Arab origin, Arabic food is in their blood. But food is not only heritage: it is often also patriotism.

Food unravels numerous meanings. For example we can often distinguish which culture people are from - national and religious - by what foods they eat and their mannerisms and attitudes. Do they pray before they eat and so forth? What you do not eat can also say who you are, that is how Christians centuries ago knew who was Jewish, because they did not eat pork. Food demonstrates the cultural traits and behaviors of a group, for instance, the hospitality (giving and sharing) of Arab culture is expressed through their continuous offering of food. Food is a gift of God, according to Islam, and should be shared. Through eating we create bonds and a social solidarity by learning about others, by learning to understand and accept their differences as well as our own. In this line of thought it is interesting to look at ancient Semitic communities. Anna Meigs reminds us that according to Robertson Smith, a Scottish theologian, these communities

understood themselves to be mystical and physical unities, as sharing a common life, as participating in an intense communality with one another and with their deity. Food and eating he understands as one means by which that communality is established and enhanced (Meigs 1997: 104).

Food is not only a distinguishing element of any ethnic group or country and an agent for social alliances; food can also be a distinctive factor in the notion of otherness. Some groups have used food to show their superiority or cultural difference. The dietary composition of the Jews, for instance, was used as an indicator of their identity, their otherness, and functioned as a source of cultural solidarity (Montanari 1999b: 190). And "In relation to the Islamic world, the pig played an absolute symbolic role, representing Christian Europe in its entirety" (Montanari 1999b: 191). However, immigrants in the United States have mostly experienced otherness in a discriminatory way. By eating other foods they have been looked down upon, have been mocked. However, gastronomical distinctions have contributed to more awareness of a given culture and it is a powerful political, religious and cultural statement that must be made by all ethnic groups. Food also 
can indicate social class, historical period, society, spiritual beliefs and eroticism (which has not really been explored in Arab-American literature). Naomi Shihab Nye's poem "Different Ways to Pray", shows the important role food plays in Arab culture and the difficulties of contemporary Palestinian life, and a spiritual moment transfigures. She writes:

Under the olive trees, they raised their arms - Hear us! We have pain on earth!

We have so much pain there is no place to store it! But the olives bobbed peacefully

in fragrant buckets of vinegar and thyme.

At night the men ate heartily, flat bread and white cheese,

and were happy in spite of the pain [...] (Nye 1995: 18).

Suheir Hammad does not exactly explore the erotic but uses "erotic language". In some of her poems, to describe oppression towards women, whether physical, mental, religious, cultural or political, she uses curse words, names private parts, uses food imagery and eating habits, which create intensely penetrating tension. She writes:

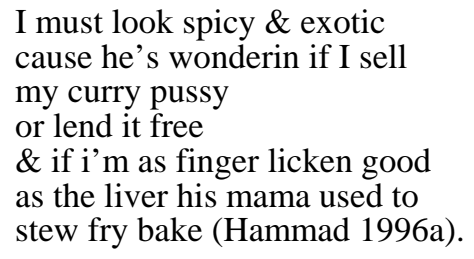

Food and eating identify the psychological characteristics of a character or a people, of a situation or given place; and it is a personal expression reflecting one's understanding, attitude and emotion towards the self and the other. We nourish and discover each other through the food we prepare for each other. In Nye's poem "The Palestinians Have Given Up Parties”, she shows the oppression Palestinians feel and live under by using images of food. She writes:

Once singing would rise

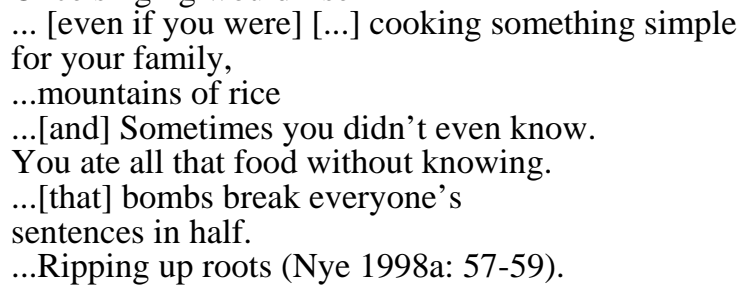


Food forms identities, regional and national; it is home for many Arab-American immigrants. Pauline Kaldas writes about food as home and how even her ethnicity is reflected in the color of Arabic food:

Homesick for the streets

[for] the smell of crisp fried falafel

and cumin spiced fava beans,

sweetshops

display their baklava and basboosa

glistening with syrup

browned like people who make them (Kaldas 2001).

When exiles or immigrants smell the spices used in Arabic cooking or eat Arabic food outside their country they immediately feel home, then often start reminiscing about their childhood, feeling nostalgic for their homeland and their past. Food also awakens in them desire and joy. Arab immigrants and those of Arab origins like Arab-American women writers grew up "tasting” their country of origin.

\section{Eating Arab \& American Food: The Formation of a New Identity and the Rise of Ethnic Foods in the United States}

Her Brooklyn kitchen's in exile [...] (Williams 1993).

The variations between each generation of Arab American immigrants - what was preserved, what was lost and how new cultures and identities were formed - differs. And after the Civil Rights Act of 1964 and the revision of the U.S. immigration laws in 1965, there were changes in Arab immigration and hence in the Arab communities in the United States. Accompanying those transformations were re-constructions of food cultures. The "Mcdonaldization" of food culture in the U.S., as the French sociologist Claude Fischler says, is one change (Fischler 1999: 530). Adding to that change is the upsurge of "ethnic fast food" such as Tex Mex and food from newer immigrants - Middle Easterners, Asians, Caribbean, Latin American etc. - indicating the important transfigurations taking place in the dietary routine of Americans. Food has been a significant vehicle of cultural awareness and awareness of cultural diversity; and this represents a departure toward a more accepting, tolerant multicultural and pluralistic America. In fact, in the past "Americans have not been as tolerant of and curious about their neighbors as they have about their neighbors' foods” (Gabaccia 1998: 
228). Thus, food has been and continues to be the least contested, most accepted element of cultural difference even if cultural barriers and misunderstandings remain. Eating the food of the Other is crossing cultural boundaries which is an important way to understand difference, acknowledge it, embrace it and make it part of your individual identity. Food creates social and economic alliances. This does not signify that people stop longing for what they have always eaten; in fact, psychologists say that the food people ate "as children forever defines familiarity and comfort" (Gabaccia 1998: 6). Rather, it simply suggests that they have agreed to culinary diversity, even though at home one regional or national cuisine is often predominant.

Donna R. Gabaccia believes that

What unites American eaters culturally is how we eat, not what we eat. As eaters, all Americans mingle the culinary traditions of many regions and cultures within ourselves. We are multi-ethnic eaters (Gabaccia 1998: 225-226).

But by agreeing to be multi-ethnic eaters, aren't Americans indirectly agreeing to become multi-ethnic? Gabaccia points out:

Hot dogs and Cracker Jacks, fried chicken and Fritos all emerged from specific cultural communities (German, southern, and Mexican) but lost their ethnic ties. Few people today think of hot dogs or Cracker Jacks as German, Fritos as Mexican-American, or Kentucky Fried Chicken as “soul food” (Gabaccia 1998: 225).

Thus she is emphasizing the point that these different foods become American food, but Americans do not become part of these ethnic groups. Although there is truth in that statement, it does not entirely hold up, and I don't think the ethnic tie has been completely lost. Even if it is at a subconscious level, I think that Americans, especially if their family originated from where that particular food came from - be it Mexico or an Arab country or German -, make cultural associations which make them feel somewhat close to or least feel familiar with that culture.

If we consider what theorists of American identity suggest, from Crèvecœur to Arthur Schlesinger,

that immigrants and racial minorities should do the same [as the food culture did], [...] that Americans are best united as a people when they lose their ties and loyalties to particularistic regional and cultural communities (Gabaccia 1998: 226-227), 
we will recognize the imperialistic traits of these suggestions. Why should ethnic groups lose their ancestral particularities? This process did not occur anyhow, for as we have seen, "American" culture did not eliminate all traces of its ethnicity and became uniquely "American”, instead, ethnic groups have hyphenated themselves to preserve their roots while still being American. Gabaccia insists that Tex-Mex has "a clear national identity that is American, not Mexican" (Gabaccia 1998: 227). She has underestimated ethnic culture. Tex-Mex is hyphenated like many Americans are, and even if it is not considered Mexican but an American regional cuisine, this Americanness is still associated with Mexican culture. The only reason it is considered more American than Mexican is because it is not authentic Mexican food, but an American version of Mexican food. In that light, it could be seen as uniquely American, nevertheless, many of the ingredients remain Mexican. I will go further and explore the more mystical economic and cultural viewpoint of Marcel Mauss in The Gift (first published in 1925):

To give something is to give a part of oneself [...]. In this system of ideas one gives away what is in reality a part of one's nature and substance, while to receive something is to receive a part of someone's spiritual essence (Mauss 1967: 10).

Mauss' thought supports the integration and circulation of cultures and selves "within each other", which would mean in this case that through hyphenated foods both sides are becoming part of each other. Tex-Mex or any other ethnic-American food would not become "solely" American, as Gabaccio suggests, but rather would become part of each other - the American part of the Other, the Other part of the American. Finally, Jean Anthelme Brillant-Savarin's famous 1825 aphorism continues to confirm itself, "Tell me what you eat, and I will tell you who you are". Americans as multicultural eaters are multiethnic.

Where is Arabic food in regard to the multi-ethnic American food scene? Its references vary and change, and are delivered as "Lebanese" or "Middle Eastern", sometimes "Israeli" or even "Vegetarian" food. It is rare for it to be referred to as "Arabic food" probably because of the polemic surrounding the word Arab and probably because of the Arab-Israeli conflict. Suheir Hammad mirrors this point, adding that there is also a tendency in the U.S. to alter the original way the 
food is cooked to fit America's norms, thus to some extent ridiculing Arabic culture. She writes:

[One] time I heard [...] white girls order falafel [...]. They wanted it extra crispy, as though it were some fried chicken or potato chips [...]. Almost choked when I heard them ask for "ghummus [...]". Wanted to tell them it was pronounced hummus [...]. When they were walking out, I heard them talking about how much they loved Israeli food and belly dance music oh-so-cute? (Hammad 1996b: 72).

Arabic food is not recognized as such, however it is part of popular American cuisine - hummus, tabbouli and pita bread are found in many cafes, restaurants and supermarkets (canned or put in plastic containers for mass consumption). Looking at the dynamics of consumerism and consumption we discover far more than simply consumer demand, it tells us much about America's societal and cultural trends, changes and metamorphoses.

Food demonstrates cultural subjugation, acceptance and appreciation, self and community development. It harvests new identities. On the other hand, food can also be taken as an indicator that immigrants resist full integration. But then again, they have negotiated by hyphenating, reinventing or Americanizing their food preparations (example: creating pita wraps/sandwiches with hummus to accommodate American fast food and/or sandwich culture). The rise of nouvelle cuisine and, later, new world cuisine is an interesting evolution to consider, for it demonstrates the rise of American culinary and social cosmopolitanism. First, nouvelle cuisine reinvented old traditional dishes, then "new world" cuisine used ingredients from different cultures when creating a dish, reflecting the merging of cultures taking place in American society.

American eating habits continue to shift, just as society's beliefs and morals change over time. These manifestations have been taking place since before modern consumerism. We eat initially to survive, which in turn has developed into a source of pleasure that increases with time and leads to a demand for novelty. Americans are increasingly curious and interested in food from their regional and national roots and foods from other ethnic groups, and their gustatory multiculturalism is increasing. Food is a cultural recipe for self-definition, as we will see in the following section. 


\title{
3. The Mezze of Roots: Representation of Food in Arab-American Women Writers
}

\author{
A cousin sent me \\ a video cassette of my family - \\ Everyone was in the kitchen (Mattawa 1995).
}

Food has appeared in most Arab-American writings - in poems, novels, plays, essays, and book titles. And the use of food in the titles of many important books by Arab-Americans - Tel Zaatar was The Hill of Thyme by Fawaz Turki, Grape Leaves, Food for Our Grandmothers among others - indicates the primal place food has in Arab-American identity and culture. When looking at the construction of food and what it represents in the work of Arab women writers, the following associations with food occur: connection with politics, relatives, families, countries of origin, and the land, customs and traditions. Food is used to define Arab societies, people and the writers themselves at a more philosophical or affective level. It is often through food that these women writers experience Arabness and Arab culture, become Arab and pass this culture down to their children. Kadi describes in Food for Our Grandmothers how olives, bread, thyme, yogurt, grape leaves and mint recur in Arab-American experience, and presents these as emblems of Arab life. For example, when these writers use olives in their works it is often linked to olive trees, which represent Arabs' long connection to their land and culture (Kadi 1994a: 3). She says that most Arab and Arab-Americans believe, "We owe it to ourselves, our ancestors, and the ones who come after us to celebrate our wonderful culture, whether we find it in the laban we eat or the stories we read" (Kadi 1994b: 237).

In his book, Great Literature of the Eastern World, Ian P. McGreal refers to an important argument by the well-known philosopher, scholar and historian Ibn Khaldun (*1332 in Tunis, †1406 in Cairo). Khaldun suggests in Muqaddimah (Introduction or Prolegomena) that "Geography, climate, and food source decide both the human body (color, stamina, intellect) and character" (McGreal 1996: 523). The Arab character often develops inside Arab-American women writers as their mothers and grandmothers feed them Arabic food. The relationship between Arab-American women and food is an important source of roots, identity, strength and self-assertiveness, 
which is ironic since food and its preparation has often been seen as taking freedom away from women. Arab-American women writers have represented being in the kitchen as liberating instead of being oppressive, as offering avenues of creativity and artisticness instead of being confining. They have used food rhetoric as a vehicle to liberate the myth from itself and to create a new space where the kitchen is a place of expression, personal and cultural, a place of self-development and enrichment. It is in the kitchen that Kadi learned about being a cultural worker. She writes, "I did not sit in that kitchen smelling warm milk and think to myself: My grandmother is engaged as a cultural worker. But that is what she was” (1994b: 232). This writer grew up understanding with some difficulty what culture meant, especially what Arab culture meant because in her home she experienced cultural displacement. The following passage demonstrates how Kadi's race, class and ethnicity affected her relationship with food. She writes:

Although my family listened to Arab music, danced Arab folk dances, and ate Arab food, I did not perceive any of this as culture. Perhaps if we had not been so isolated from a larger Arab community things would have been different. But as it was, the people around us, and society generally, perceived our music and our food on good days as a series of weird, isolated, and exotic behaviors that for some reason my family engaged in. On bad days they perceived it as disgusting as well as weird (Kadi 1994b: 232).

Like so many other Arab-American writers, she later understood and stated:

It is only now [...] that I understand I grew up surrounded by Arab culture. It is only now that I understand what happened in my grandmother's kitchen. It is only now that I perceive the connection between what I do as a cultural worker and what my grandmother did when she made laban (Kadi 1994b: 232).

It is only later on in D. H. Melhem's life that she understood that her "grandmother [was] always working peeling potatoes/ [and her] mother also" (Melhem 1995: 18). Like Kadi, many of these women writers later defined themselves by way of what they ate in their childhood. The social and cultural diversity among Arab-American women writers - what Arab country they originate from and what part of the U.S. they were raised in - can be seen by the food they describe. In Drops of this Story, Suheir Hammad illustrates her multiplicity through the variety of food she ate growing up. She writes: 
I tell you I was raised around the delicious stinks of the ghetto. Fried plantains and smoked refers, my mother's stuffed eggplants and the neighbor's pork ribs. Our apartment building was always swaying with smells of the East, the Caribbean, and the South (Hammad 1996b: 6).

Jocelyn M. Ajami, ${ }^{2}$ also discovers and defines herself through food: "I thought of myself as Latin American until I was a teenager and realized that hummus and caraotas con arroz (black beans and rice) were not part of the same banquet” (Ajami 2000). Mohja Kahf uses food to describe herself, she is/becomes the recipe of an Arabic dish: "I am scented oil; I am spice, I am rice of every hue cooked with nuts, pine and pistachio". ${ }^{3}$ Hammad does the same in "may I take your order?” when she writes:

I'm the main dish

walkin down the street

my face a menu

...olive skin almond eyes bitter tongue (Hammad 1996a).

The poet in her poem "mama sweet baklava"4 not only describes and refers to an Arab woman using a type of food but demonstrates cultural succession through food while also conveying Palestinian lives of exile, fragmentation and suffering:

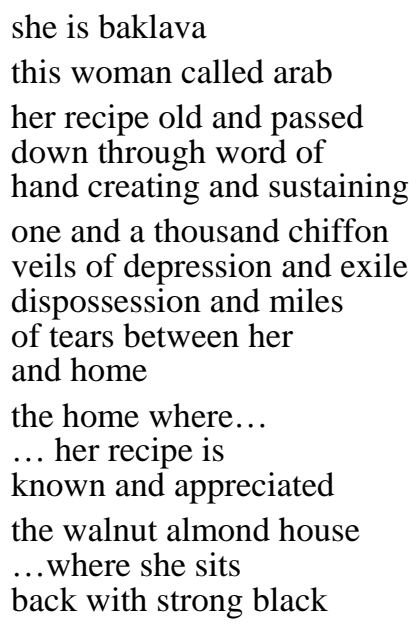

2 Ajami is a painter, filmmaker and writer born in Caracas, Venezuela to ArabChristian parents. She resides in Boston.

3 "From the Patios of the Alhambra", unpublished poem, sent by the author.

4 Published on <http://www.cafearabica.com>. 
coffee and finally

tastes herself...

She "tastes herself”, finds herself and home in Arabic food. Hammad said during a reading at City University of New York (April 27, 2001) ${ }^{5}$ that when people ask her about baklava she says, metaphorically speaking, "it has to be Arabic, it is so complicated".

Elmaz Abi-Nader describes her land of origin, Lebanon. She tells us of its richness and demonstrates the important place storytelling holds in Arab culture, particularly stories about food, for example, uses of fruits and its trees. She writes:

The tales my mother and father told me are true: the apricots are as big as oranges and as bright as the sun.

Grapes sag on the vine from the wealth of wine already inside of them.

The figs burst

as you walk through groves,

begging for you to hold on [...] (Abi-Nader 1999a: 18).

It was also when Abi-Nader's Sitti (grandmother) was teaching her how to cook, "how to crease the spinach pies right down/ the middle" that she discovered much about her Sitti's cultural ways and values, and the poet never ceased to "listen as [her Sitti] told [...] her stories" (Abi-Nader 1999b). She also never ceased to listen to the sounds of food in the souqs in Yemen. The poet uses food imagery to describe the place, "Pyramids of pots and oranges,/ alps of curry, sumac and cumin” (Abi-Nader 1999c). And Nye uses food to describe pain, uses food as a symbol Palestinians lean on and hold to. She writes:

[...] the way he carried oranges and falafel in his pockets the way he was always slightly mad (Nye 1994).

It is similar to the way Abi-Nader's Sitti holds on to the food as she

Crawled

behind the lines of Turkish soldiers

flour and rice hanging in bags in the cave

of her arms pits (Abi-Nader 1999d).

5 Talk on "The Poetry of Arab Women" by Nathalie Handal followed by readings by Handal, Hammad and Melhem held at City University of New York (CUNY), April 27, 2001. 
D. H. Melhem equally experienced culture, her mother, her grandmother and herself in the kitchen, as the three of them connect while making food. She writes, in this penetrating portrayal of Arabic culture, of three generations of Arab women and their relationship with food, how in the kitchen they made cultural statements as well as sent messages of resistance, persistence and determination:

It is warm in Grandma's kitchen [...] [a] kitchen... warmed all day by the cooking [...]. My mother, my grandmother sit at the white enamel kitchen table, kneading dough, shelling peas, measuring pine nuts into the chopped lamb and onions, soaking the crushed wheat for kibbeh filling dozens of meat pies, stuffing chicken and squash and green peppers and eggplant, rolling stuffed grape leaves and stuffed cabbage like cigars, making dumplings for yoghurt soup among cans of sesame oil and boiled butter, peeling scores of potatoes for baked lamb necks and shanks and roast chicken, boiling rice, browning rice and onions, adding rice and tomatoes to large pots of marrow-bone vegetable-soup, sitting and chatting [...]. I watch and listen, tasting dough and stuffing [...] [while absorbing] the strange names of relatives and friends I shall never meet, Beit this and Beit that, houses remote as the house of Atreus, incidents and characters recalled and savored as I anticipate the mention of meaningful names dropping from the flow of Arabic between them: aunts and uncles who live in the house, my mother's sisters and brothers. I bear witness to a daily translation of two women's lives into pots and pans (Melhem 1995: 17).

Michaela Raen expresses a longing for the past, for her ancestors and herself through food:

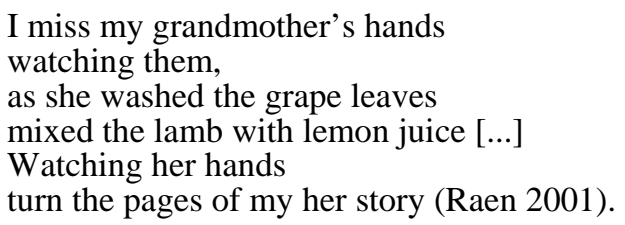

As we have seen, these women's grandmothers played an essential role in transmitting Arab culture, mostly in the kitchen through food and storytelling.

Dima Hilal writes in "ghaflah - the sin of forgetfulness" about the people of Lebanon, loss of self and perspective, cultural shame nourished by immigrant experiences of discrimination and feelings of inferiority, and acceptance of degradation by eating the modified version of their cultural dish. She writes: 
we eat pasty hummous at eight dollars a plate and tell each other how much we miss our home (Hilal 2001).

The following poets communicate through their usage of food different traits and features of Arab culture. Melhem says:

sunday at grandma's: politics and dishes

the men playing cards (Melhem 1995: 31).

Lorene Zarou-Zouzounis writes:

filling the air with aroma

of a culture of olive,

almond and fig groves (Zarou-Zouzounis 2001).

Nadia Hazboun Reimer describes in “The Middle East”.

no, it is not only the date clusters

in the palm trees

but also the oil, the phosphate. The potassium, the olives, the citrus,

the salt,

the milk and honey,

and the manna that falls from heaven (Hazboun Reimer 2001).

And Lisa Suhair Majaj does the same when she describes her visit to the West Bank in late March 1997, reconfirming how life in the Arab world revolves around food. She writes, "The waiter brings hummus, mtabal; many kinds of salads. The waiter brings trays of kebab and kefta, baskets of stone-baked bread, platters of oranges and bananas”. 6 Majaj delivers the goods of the Arab world that often appear and reappear in the writings of these poets,

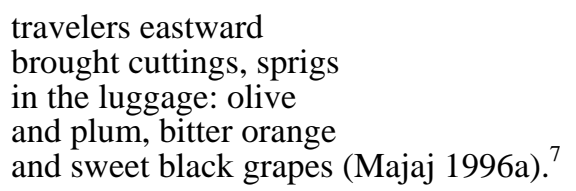

A comparable scene appears in S.V. Atalla's poem "Visiting the West Bank":

6 “The Day", unpublished poem, sent by the author.

7 Also published in International Quarterly (1994) and Mr. Cognito (1991). Translated into Arabic and published in the Arabic version of Salma Khadra Jayyusi's Anthology of Modern Palestinian Literature. 
Every time we arrive this unloading begins. From freezer and pantry the delicacies of each season: vine leaves wrapped in April, winter's marmalade, quince jelly; zaatar dried in June (Atalla 2001).

In the following passage, Hammad conveys the dilemmas of doubleness and the ways she has negotiated her identity through food:

It lives on the back of my tongue. Where the taste of falafel and hummus mingles with the bite of plantain and curry. Why couldn't we just eat pancakes and bacon like everybody else? We had to have olives at every meal and pita bread with everything. I know now that I always loved that food. It's just hard to be different all the time. When it became cool to eat hummus, falafel, taboulleh, and pita with everything, it was too late. I had already wasted years of trying to trade my labeneh sandwiches for peanut butter and jelly, which I didn't even like. I know now that I was just another immigrant kid, trying to fit in (Hammad 1996b: 51-52).

Nye demonstrates her dualness by telling her readers what she ate at home when she was young and what was eaten around her. The poet in the following passage also draws a picture of most Arab homes, filled with stories and imagination:

Our Palestinian father was a wonderful storyteller. Every night my brother and I drifted off to sleep wrapped in the mystery of distant neighbors, villages, ancient stone streets, donkeys, and olive trees. Our house by day was fragrant with cardamom spice and coffee, pine nuts sizzled in olive oil, and delicious cabbage rolls. My girlfriend brought iced cupcakes to girl Scouts for treats, but I brought dates, apricots, and almonds (Nye 1998b: vii).

In Mohja Kahf's poem “The Roc”, she speaks about immigrating and entering another culture through its food market and new food habits. She writes:

Here's my mom and dad leaving... Damascus

...the daily boiling and cooling of fresh milk.

...Here they are crossing the world,

...They know nothing

about America: how to grocery

shop

...how the milk comes, thin glass bottles

...mom [laughs] at the strange loaf of bread

...dad holding up the new world coffee (Kahf 2001).

Beverages also appear in the work of these women authors, especially references made to coffee: the different meanings it projects in Arab culture and its strong association with Arab culture. To offer a cup of coffee in the Arab world is very common and is a gesture of hospi- 
tality and welcome. The scholar Ralph S. Hattox tells us that, "Coffee came into general use in the lands of Islam sometime in the midfifteenth century” (Hattox 1988: 11). Also,

Coffee, or at least the consumption of the fruit of the plant [...] is usually traced to Ethiopia. It is there that those who are traditionally credited with introducing it into general use in the Islamic world are said to have first seen it (Hattox 1988: 13).

About coffee, childhood and culture, Hammad writes:

Stirred into the heavy Arabic coffee and Café Bustelo of my childhood. Don't like coffee too tough. When I was little, Arab women would tell me that young girls who drank coffee would grow heavy mustaches. There were other warnings from these frustrated women who found themselves in loveless marriages (Hammad 1996b: 80).

Nye writes an entire poem on coffee entitled "Arabic Coffee” emphasizing the importance of Arabic coffee in an Arab household. The poem describes the way Arabic coffee is made and served, and the storytelling, reminiscing and longing that accompanies drinking coffee. She writes:

It was never too strong for us: make it blacker, Papa, thick in the bottom, tell again how the years will gather in small white cups.

Serving coffee, the expression of Arab hospitality and continuity,

was an offering to all [his guests]

stay, be seated, follow the talk

wherever it goes. The coffee was

the center of the flower.

.... motion of faith (Nye 1995: 130).

Majaj combines coffee and food when illustrating "Jerusalem":

In the Old City, grocers scoop rice and wheat

from huge sacks, pour grain into deep brass scales measure anise and cardamom and thyme.

When sun slips into the pans it's swept up

without charge, the way you don't pay for the fragrance

of coffee, zaatar's bright swirl of sumac.

The poem continues, expressing grief and melancholy with food rhetoric, 
Not like the mass of sorrow

weighing the air beneath the odor of cumin, that tips the scales in every reckoning (Majaj 1996b).

Arab-American women writers have also used food to address famine, as well as alimentary problems of contemporary society such as bulimia, anorexia, food obsession and over-eating. In "When Fat Women Fear Famine", Brenda Moossy demonstrates some of the characteristics mentioned above. She writes:

When women fear famine,

not even their children are safe.

...These women are vigilant

against the threat of wanting.

They are full-fleshed warriors

waging war against the enemy

they cannot see

...hear

.... They know the pain of the gnawing heart,

the ache of the hollow bone (Moossy 1997: 10-11).

As we have seen, food has many meanings. It can be a symbolic representation of someone, of a culture or an emotion, or it might be used to express, relay a message or set the stage for a love scene or any event. But beyond that we all have an intimate relationship with food that never ends. Food is its own language and encompasses our entirety - our roots, our old and new identity and culture, our bodies and minds, our loves and desires, ourselves.

\section{Bibliography}

Abi-Nader, Elmaz (1999a): “In the Country of My Dreams”. In: In the Country of My Dreams. Oakland: Sufi Warrior, p. 18.

- (1999b): “Burning Bush”. In: In the Country of My Dreams. Oakland: Sufi Warrior, p. 21.

- (1999c): “Letter to Yemen”. In: In the Country of My Dreams. Oakland: Sufi Warrior, p. 30.

- (1999d): "Pleasure Is Freedom-song”. In: In the Country of My Dreams. Oakland: Sufi Warrior, p. 24.

8 Also published in The Jerusalem Times (4 April 1997). Translated into Hebrew and published in Noga (Spring 1997). 
Ajami, Jocelyn M. (2000): “A different path”. In: Melhem, D. H./Diab, Leila (eds.): A Different Path: An Anthology of the Radius of Arab American Writers. Detroit: Ridgeway, p. 2.

Atalla, S. V. (2001): “Visiting the West Bank”. In: Handal, Nathalie (ed.): The Poetry of Arab Women: A Contemporary Anthology. New York: Interlink Publishing, p. 85.

Bresciani, Edda (1999): "Food Culture in Ancient Egypt”. Trans. Clarissa Botsford, et al. In: Flandrin, Jean-Louis/Montanari, Massimo/Sonnenfeld, Albert (eds.): Food: A Culinary History. New York: Columbia University Press, pp. 38-45.

Burton, Richard (2000): “A Dinner in Mecca”. In: Silverman, Jeff (ed.): The First Chapbook for Foodies. Emeryville: Woodford, pp. 66-69.

Counihan, Carole/Van Esterik, Penny (1997a): “Introduction”. In: Counihan, Carole/ Van Esterik, Penny (eds.): Food and Culture: A Reader. New York: Routledge, pp. 1-8.

- (1997b) (eds.): Food and Culture: A Reader. New York: Routledge.

Fischler, Claude (1999): “The 'McDonaldization' of Culture”. In: Flandrin, JeanLouis/Montanari, Massimo/Sonnenfeld, Albert (eds.): Food: A Culinary History. New York: Columbia University Press, pp. 530-547.

Gabaccia, Donna R. (1998): We Are What We Eat: Ethnic Food and the Making of Americans. Cambridge: Harvard University Press.

Gelber, Lynne L. (1989): “Creation and Annihilation: uses of Food in Contemporary French Narratives”. In: Schofield, Mary Anne (ed.): Cooking By the Book: Food in Literature and Culture. Bowling Green: Bowling Green State University Popular Press, pp. 159-169.

Giammellaro, Antonella Spanò (1999): "The Phoenicians and the Carthaginians. The Early Mediterranean Diet.” In: Flandrin, Jean-Louis/Montanari, Massimo/Sonnenfeld, Albert (eds.): Food: A Culinary History. New York: Columbia University Press, pp. 55-68.

Hammad, Suheir (1996a): “may I take your order?” In: born Palestinian, born Black. New York: Harlem River, p. 67.

- (1996b): Drops of This Story. New York: Harlem River.

Hattox, Ralph S. (1988): Coffee and Coffeehouses: The Origins of a Social Beverage in the Medieval Near East. Seattle: University of Washington Press.

Hazboun Reimer, Nadia (2001): “The Middle East”. In: Handal, Nathalie (ed.): The Poetry of Arab Women: A Contemporary Anthology. New York: Interlink Publishing, p. 256.

Hilal, Dima: (2001): "ghaflah - the sin of forgetfulness”. In: Handal, Nathalie (ed.): The Poetry of Arab Women: A Contemporary Anthology. New York: Interlink Publishing, pp. 119-120.

Joseph, Lawrence (1988): Curriculum Vitae. Pittsburgh: University of Pittsburgh Press.

Kadi, Joanna (1994a): "Part I - Olives. Our Roots Go Deep: Where We Came From”. In: Kadi, Joanna (ed.): Food For Our Grandmothers: Writings by Arab-American and Arab-Canadian Feminists. Boston: South End, pp. 3-4. 
- (1994b): "Five Steps To Creating Culture”. In: Kadi, Joanna (ed.): Food For Our Grandmothers: Writings by Arab-American and Arab-Canadian Feminists. Boston: South End, pp. 231-237.

- (1994c) (ed.): Food For Our Grandmothers: Writings by Arab-American and Arab-Canadian Feminists. Boston: South End.

Kahf, Mohja (2001): “The Roc”. In: Handal, Nathalie (ed.): The Poetry of Arab Women: A Contemporary Anthology. New York: Interlink Publisher, pp. 141143.

Kaldas, Pauline (2001): “Home”. In: Handal, Nathalie (ed.): The Poetry of Arab Women: A Contemporary Anthology. New York: Interlink Publisher, pp. 146147.

Majaj, Lisa Suhair (1996a): “Tata Bahiyeh”. In: Al Jadid Magazine II, p. 9.

— (1996b): “Jerusalem”. In: Al Jadid Magazine II, p. 9.

Mattawa, Khaled (1995): “Three Kitchens”. In: Ismailia Eclipse. Riverdale-on-Hudson: Sheep Meadow, p. 16.

Mauss, Marcel (1967): The Gift. New York: Norton.

McGreal, Ian P. (1996) (ed.): Great Literature of the Eastern World. New York: Harper Collins.

Meigs, Anna (1997): "Food as a Cultural Construction”. In: Counihan, Carole/Van Esterik, Penny (eds.): Food and Culture: A Reader. New York: Routledge, pp. 95-106.

Melhem, D. H. (1995): Rest In Love. $2^{\text {nd }}$ ed. New York: Confrontation.

Montanari, Massimo (1999a): “Food Systems and Models of Civilization”. Trans. Clarissa Botsford, et al. In: Flandrin, Jean-Louis/Montanari, Massimo/Sonnenfeld, Albert (eds.): Food: A Culinary History. New York: Columbia University Press, pp. 69-78.

- (1999b): "Food Models and Cultural Identity”. Trans. Clarissa Botsford, et al. In: Flandrin, Jean-Louis/Montanari, Massimo/Sonnenfeld, Albert (eds.): Food: A Culinary History. New York: Columbia University Press, pp. 189-193.

Moossy, Brenda (1997): Anaconda. Fayetteville: Snake Works.

Nye, Naomi Shihab (1994): “The Grieving Ring”. In: Red Suitcase. Brockport: BOA Editions, pp. 95-96.

- (1995): Words Under The Words: Selected Poems. Portland: Eighth Mountain.

- (1998a): Fuel. Rochester: BOA Editions.

- (1998b): "Introduction”. In: Nye, Naomi Shihab (ed.): The Space Between Our Footsteps. New York: Simon \& Schuster, pp. i-ix.

Raen, Michaela (2001): “La Sombra of Who I Am”. In: Handal, Nathalie (ed.): The Poetry of Arab Women: A Contemporary Anthology. New York: Interlink Publishing, pp. 251-254.

Shakir, Evelyn (1997): Bint Arab: Arab and Arab American Women in the United States. Westport: Praeger. 
Sonnenfeld, Albert (1999): “Preface”. Trans. Clarissa Botsford, et al. In: Flandrin, Jean-Louis/Montanari, Massimo/Sonnenfeld, Albert (eds.): Food: A Culinary History. New York: Columbia University Press, pp. xv-xviii.

Williams, David (1993): “For My Grandmother”. In: Traveling Mercies. Cambridge: Alice James, p. 28.

Zarou-Zouzounis, Lorene (2001): “Embroidered Memory”. In: Handal, Nathalie (ed.): The Poetry of Arab Women: A Contemporary Anthology. New York: Interlink Publishing, pp. 317-319.

Zubaida, Sami/Tapper, Richard (1994a): “Introduction”. In: Zubaida, Sami/Tapper, Richard (1994b) (eds.): Culinary Cultures of the Middle East. London: I. B. Tauris, pp. 1-18.

- (1994b) (eds.): Culinary Cultures of the Middle East. London: I. B. Tauris. 


\section{Verónica Murguía}

\section{My Unknown Forefathers}

I am here because I am a Mexican writer interested in the Arab culture and, more precisely, in the poetry of al-Muttanabbi. This very keen interest of mine has been perceived as odd in Mexico: a quaint little hobby (a tad eccentric too, the result, maybe, of reading too much or of taking strange courses during my college years). But it is, at least for me, natural just because I speak Spanish, that beautiful language brought to America by the Spanish conquerors.

My country, Mexico, its culture and very problematic identity are the result of an extraordinary and dramatic historic event: the Conquest. That is, the almost complete destruction of the ancient Aztec Empire and of its capital city, the great Tenochtitlán. In the year of 1519, the Spanish captain Hernán Cortés decided to take by force the neuralgic center of this portentous empire. When he arrived at the gates, however, the gates were opened to his army without a single skirmish. Why? Because, in one of history's ironic turns, the wise men of Moctezuma's court had predicted the arrival of white, bearded men. Demigods, avatars of Lord Quetzalcoátl, and benevolent. Neither the prophecy nor the solemn welcome were considered when the Spanish army decided, nonetheless, to obliterate the city by blood and fire.

The Aztec people fought valiantly against the worst odds of all, thinking they were facing gods bent on destroying them. The rest is history. The history of my country.

In elementary school, Mexican children are taught that at least four thousand words of our language come from Arabic. Teachers taught us that these words come from a language of astonishing expressive power. We learned then that the names of many flowers: azahar, amapola, jazmín; trades, albañil, perfumes, food, and that color full of poetic meaning in Spanish, azul - blue, come from the Arabs.

Later, I bumped painfully into algebra. And on the cover of my thick algebra book - the Baldor, the most popular math syllabus among Mexican students - there was the bearded and turbaned face of 
al-Juarismi. It was a surprise: those mysterious Arabs that bestowed on us the four thousand words also discovered algebra, among many other things. To name them is maybe pointless, but for a girl of fifteen whose interest was suddenly piqued, the long list of scientific, philosophical and artistic feats was mesmerizing.

Those Arabs live in the everyday Mexican speech, in the popular sayings and proverbs - Zutano o Fulano; De la Ceca a la Meca; el oro y el moro; mira si hay moros en la costa; no veas moros con tranchete; olé, ojalá [...] - and in the subtleties of poetry. And there was even more: we were told then, and were intrigued by this, that before the Conquest there was another phenomenon of this sort. The Reconquest. It happened in Spain, and the main characters in this event were the Spanish Arabs and the Catholic Kings, the same twosome responsible of financing Christopher Columbus' trip to the East, and therefore to America. A Reconquest before the Conquest? How come?

And guess what ... those Arabs of Spain stayed in the Peninsula roughly eight centuries. Almost twice the time the Spanish stayed in Mexico. So the unavoidable and sometimes problematic relationship between Mexico and Spain grew a branch of deep interest, the Arab culture.

Then, more delightful evidence of the true extent of this relationship, this proximity with the Arabs, appeared everywhere, but maybe the most spectacular I found is the delightful scheme in the plot of Don Quixote, the novel that creates the genre, that living jewel of the Spanish literature. It has to do with Cide Hamete Benengeli, the Arab scholar and historian that wrote, according to this game, the stories of Don Quixote. Under that guise hides Miguel de Cervantes, just like under the layers of time hides the Arab world that once existed in Spain. From the beginning of the novel till the last page, the novelist Miguel de Cervantes poses as the Spanish commentator and editor of the writings of the Arab scholar Benengeli.

A few years after realizing this, I read my first adult version of The Arabian Nights in a wonderful translation by Rafael Cansinos Asséns. Of course, like any child anywhere, I was already enchanted by the stories of Aladdin and Simbad. As an adult, I was astonished by the narrative's cunning and subtleties in The Arabian Nights; I found it full of life, enriching and joyful. Of course the teachings of a writer 
as generous as Jorge Luis Borges, the most famous admirer of The Arabian Nights, and maybe my favorite contemporary writer in Latin America, created many possibilities. He wrote hundreds of pages devoted to the Arabs and taught the writers of Latin America that any tradition we love can be adopted and that, if we wished, we could write about other cultures. This, as Borges found, is hard because there are some picturesque things expected from us Latin Americans. North Americans, and some Europeans, find it very strange and a little disquieting when a writer of Latin American origin does not dwell on certain topics. A novelist from my country, sadly, is expected to write only rural novels, portraying the harsh realities of the Mexican countryside (which, by the way, continue to be as harsh as ever).

Or, being a woman, one should write about machismo and women. (Men in Mexico are as macho as ever, too, and sometimes worse, and the awful killings of women on the border and the shameful attitude of our government should convince anyone harboring doubts about this). The great Mexican novelist Juan Rulfo has written the most powerful novel situated in the post-revolutionary Mexico, Pedro Páramo, a story laced with his somber and dark brand of magic realism so different from the magic realism of the wonderful writer Gabriel García Márquez, but just as beautiful.

I am afraid that it is impossible to even attempt to get any better than that. But anyway, now one is supposed to write a mish-mash of narco-crime-political novels, or magic-realism-Indian-woman-empowerment novels. But writers not only write about things that should be denounced or that portray their culture. Once I even began to write a paper entitled "Egypt and Mexico: a lot more than just pyramids". I wanted to write about Naguib Mahfouz and how the adaptation of one of his novels into a Mexican movie was done smoothly, how in his novel and in the movie not once camels or donkeys, those ubiquitous symbols of Egypt or Mexico, appear.

Novelists write about things that they like, and taste is the most intimate of mysteries: it is true, runs deep, and can't be explained. And I love al-Muttanabbi and the pre-Islamic poets, even if the context of their work is so far from mine. And I love Arab architecture, have spent many a happy day listening to Om Khalsoum, and I love many contemporary Arab novelists. 
Why? What's the point in trying to answer this? It is powerful art, and for me that is enough. I have not, at least that I know of, a single Lebanese or Syrian blood relative, even if there are thousands of people of Arab descent in Mexico. But no, I do not have any, not even an in-law. I have duly - and happily, really - read Edward Said's Orientalism and did not only find it true, but relevant in a very surprising way for any Latin American. And in those intense college years I also read La invención de América by Edmundo O’Gorman, a book that parallels and precedes Orientalism. Doctor O'Gorman, one of our best historians, lucidly analyses how the Conquest and the colonization of America consolidated in Europeans a notion of natural superiority that even now gravitates over decisions and attitudes that have to do with immigration, refugees, social and political problems. Latin Americans and Arabs share some of those problems, but I don't think we, as societies, are very similar. The ways in which we are similar, I must say, is the way we are misinterpreted. Islam and the Arab world are perceived in the U.S.A. and some parts of Europe as a monolithic world. So is Latin America. It does not matter if the things we share are as important as the differences - imagine an ignorance so vast that it perceives a world that encompasses a whole continent, in the case of Latin America, as one country! For them, incredibly, Brazil and Cuba are the same, or Colombia and Mexico, or Chile and Argentina. That provincial and bigoted idea, sadly, is very pervasive in the U.S.A. We, from the Rio Bravo to Patagonia, are all the same. We are supposed to have picturesque manners, a perverse tendency to laziness and are, naturally, heirs of glorious and mysterious pasts with secrets hidden in the fog of millennia. Naturally we, Hispanics, that strange term, are now very backward. I have spoken to people in the States and Canada that have called me, to my surprise, articulate. Once, working out on the treadmill of the gym, someplace in Canada, a woman asked me with a sympathetic smile if "living among so many donkeys was hard”. Mercifully, I was so astonished I couldn't answer. But this is something that happens all the time, even among friends. A very dear Spanish friend of mine called me "Aztec" once, and that surprised me because my family's Indian roots are firmly placed in Yucatán, where no Aztec ever dwelled. If anything, I am a mestiza with a Mayan side.

Such ignorance, and in the case of North Americans, such rampant bigotry, is very dangerous. Concerning the Arab world, the ignorance 
of the North Americans allowed the monstrous propaganda of the Bush administration to go unchallenged by the voters. For them Afghanistan, Iraq, Lebanon, Palestine, Algeria, Morocco, the list could go on and on, are all the same. But I have to retrace my steps, because I was explaining an impact of an esthetic nature, an impact so deep that it shaped the story of my first novel and of many of the things I read and write. The careful reading of the Borgesian short story La busca de Averroes, with its historical implications, fueled my resolve to write something that paid homage to the Arabs and the linguistic heritage that enriched the Spanish I speak. I read Miguel Assín Palacios, La escatología musulmana en la Divina Comedia, and thankfully discovered an intelligence that has been a beacon for me throughout these years in the books of Don Emilio García Gómez. I also read avidly Adonis and Barbara Pinckeny Stetkevchych. Every open door led to more doors, and a few years later I was immersed in a literary universe so complex that I feel I just have begun looking around. The sheer terror of reading the poetry of Tabbata Xarran, the bandit-poet of pre-Islamic times, equals the first reading of Lautréamont. That is why I chose the form of fable for my first novel and used many words that in some way flaunted their Arab origin.

I also tried to divide the story in the three parts that compose the qasidas. So that is why, as in the nasib, there is a lengthy description of the little village where Auliya, the main character, is born. And she walks through the desert, and there is a rahil, then she goes back to the tribe, and in the epilogue I tried to write a madhi. This is not explicit. This was a scheme for myself and for anyone that likes Arab poetry. The fate of the novel has been a fortunate one. It has been translated, to my very great surprise and gratitude, and has editions in other countries. I took many liberties, mixing landscapes, legends and customs, but it is an Arab novel, I think. It has proven Borges right. It is a legitimate love letter to those four thousand beautiful words, and the joy of life that those words convey in Spanish. If the novel has any worth, this surely has its origins in the strong desire that I had while writing it: I wanted to pay homage to my unknown forefathers. 

Dieter Ingenschay

\section{Between the Boom and the Arabesque. 'Hemispheric Writing' in Juan Goytisolo's Paisajes después de la batalla and Milton Hatoum's Relato de um certo Oriente}

\section{Introduction: Two Novels}

"Un acontecimiento capital de la historia de las naciones occidentales es el descubrimiento del Oriente. Sería más exacto hablar de una conciencia del Oriente", writes Jorge Luis Borges in the opening paragraph of "Las mil y una noches", his essay on the Arabian Nights (Borges 1980: 57). ${ }^{1}$ While Sheherazade, whenever she appears in Borges' tales, reminds the reader of the mythic qualities of the Arabic fairy-tales and their charming gesture, Borges as the author of the essay delivers more theoretical observations on the relation between Orient and Occident. More than 50 years after its publication, the essay accrues a twofold, highly suggestive and topical meaning for contemporary readers. From a 'political' perspective, Borges anticipates Edward Said's notion of the Orient as an occidental construction of "otherness" (Said 1978), which simultaneously excludes all hegemonic thought, as it reveals itself, for example, in Samuel Huntington's The Clash of Civilizations (Huntington 1996).

Borges stresses the fact that the relation of Orient and Occident is undoubtedly one of the most established and at the same time problematic, if not even tragic (Borges 1980: 59) figures of thought in cultural history. Also, as he points out, the idea of the Orient is associated with Islam. As a geographical unit, he continues, 'the Orient' does not exist (except in reference to Uruguay, that Argentineans call the 'Orient', and the official name of the state is "República del Oriente de

1 "A capital event in the history of Western nations is the discovery of the Orient. It would be more exact to speak about the awareness of the Orient." - The translations of all critical Spanish or Brazilian texts are, unless otherwise mentioned, mine (D. I.); quotations from both novels follow the existing English translations. 
Uruguay”). Consequently, approaching the Orient-Occident dichotomy remains merely an 'approximation' for Borges ("Busquemos una aproximación”, Borges 1980: 58). And into this "sometimes belligerent love affair between the Orient and the Occident" (Borges 1980: $62),{ }^{2}$ he includes the so-called Discovery of the Americas, "as America was discovered by the desire to find a passage to India” (Borges 1980: 62). ${ }^{3}$ Thus, one could read Borges with Ottmar Ette's concept of the 'hemispheric construction of cultural processes' ${ }^{4}$ Borges not only understands the Orient and the Occident as complementary and hemispherically constructed, but he includes America into this model. This nexus allows for an 'ArabAmerican' concept.

The same is true for both of the novelists and the works that will be presented in the following reflections: Juan Goytisolo's Paisajes después de la batalla (Goytisolo 1982; 1987) and Milton Hatoum's Relato de um certo Oriente (Hatoum 1989; 2004). A special connection to the Arabic world as well as particular intertexts link both works and assure their 'selective affinity', even if, at the first glance, the comparison between both authors lacks all evidence - one is Spanish, the other Brazilian, one is a favourite subject of Hispanic criticism, the other known only by a restricted group. I will show that these different novels, however, can be read as paradigms of hemispheric writing in the sense proposed by Ottmar Ette for this volume.

\subsection{Paisajes después de la batalla}

In 1982, Juan Goytisolo, probably Spain's most important living author, published Paisajes después de la batalla, a strange narrative, which attained much less success and critical attention than his preceding and following novels and essays. It is an extremely fragmentary text; not only in terms of its narrative structure, but also because it lacks a coherent story. This is why the following summary has to shorten and leave out large parts of the rich plot (if there is any).

The 88 short fragments are connected by a nameless and above all unpleasant mid-age protagonist, an eccentric loner living in the city of

\footnotetext{
“comercio amoroso y a veces belicioso del Oriente y del Occidente".

"ya que América fue descubierta por el deseo de llegar a las Indias".

For details on the concept of the hemispheric construction cf. the dossier dedicated to "Construcciones hemisféricas" in Iberoamericana (Braig/Ette 2005).
} 
Paris at the time of the publication of the book. One morning, when waking up, 'our individual' (as he is repeatedly called) notes that the whole city has been 'Arabized' overnight. From the street signs to the title of his preferred newspaper, the communist L'Humanité, all the well known French words have been replaced by their Arabic equivalents, - a situation which leads to chaos in traffic and to the silent superiority of immigrants (who are called 'metecos', vaguely recalling the 'métèques' in a popular French chanson of Georges Brassens). The ordinary citizen, however, is more than puzzled:

Numerosos automovilistas de provincias asomaban la cabeza por la ventanilla y trataban de adivinar el significado de un cartel con varias flechas indicadoras: ¡si al menos fuera bilingüe! ¿Qué coño quería decir مر كز بو مبيدو 'وبر او كنكر (Goytisolo 1982: 15).

Within his apartment, 'our individual' urinates into the sink and clips from newspapers not only pornographic ads, but also political information about the battle of the Otekan nation (which had been extinguished centuries ago). He has not seen his wife for months, although she lives next door. Dressed in a raincoat and a hat, he uses the subway to get around the city, goes to cinemas, looks for paedophile adventures, or attends secret meetings of strange minoritarian political groups. Trying to 'read' the city and the particular structure of the 'semiotic' spread of information, he is sort of a negative and postmodern version of Balzac's flâneur.

It is a decisive characteristic of the novel that it displays its own fragmentary character. Similar to the action, also the protagonist and, as we shall see later, the narrator are fragmented. The sum of the pieces turns against all causal logic, for there is neither temporal nor 'narrative' coherence. Neither is there any relation of probability between the elements or mini-stories. Instead the reader discovers spatial connections (such as the cinema, the subway) or thematic blocks: the battle of the vanished Otekian nation, the perverse and paedophile activities of the protagonist, the ironic treatment of doctrinarian Marxism (still of some political influence in the early 1980s). At one point the protagonist himself will be torn to pieces by a bomb that appears

5 "Countless drivers from the provinces stuck their heads out of the windows of their cars, trying to figure out the meaning of a street sign and its pointing arrows: it should at least be bilingual! What the hell did مركز بومبيدو اوبرا كنكر (Goytisolo 1987: 6). 
in the course of the plot and live on normally in the next fragment. This structure of collage affects the language of the novel and its large range from scientific expressions to the slang of pornographic ads, lyrics and epistolary style.

Critics have described this as the interplay of fictions of $1^{\text {st }}$ and $2^{\text {nd }}$ degree, stressing that the fictional levels require, according to their status of reality, a vertical reading (lectura vertical), as persons and episodes that we take to be real are declared fictitious later (Martín Morán (1987). Just like the concepts of reality, probability and logic, the status of the narrator himself has to be questioned, and the text itself reminds the readers to do so:

Cuidado, lector: el narrador no es fiable. Bajo una apariencia desgarrada de franqueza y honradez -mientras multiplica los mea culpa y cargos contra sí mismo- no deja de engañarte un instante (Goytisolo 1982: 177). ${ }^{6}$

Repeatedly, the reader is addressed:

El sufrido lector de esta narración confusa y alambicada tiene perfecta razón en plantearse una serie de preguntas sobre sus silencios, ambigüedades y escamoteos y, según tememos, se las está planteando ya (Goytisolo 1982: 145).

Thus, the reader turns out to be the (meta-)narrator's confederate, and Martín Morán is right to consider the reader to be the real producer of sense. In his production, he may prove to be limited, however, unless he understands some Arabic, because Goytisolo inserts, as we saw in the first quotation above, some of the Arabic words that appear in the city of Paris and that the 'ordinary' Western reader will fail to comprehend. What seems a ludic trick, a spleen of the Arabophile novelist Goytisolo, recurs over and over again in his fictional writing. It foreshadows in some way his increasing enthusiasm for the Arabic world and his project to create understanding for it, most palpably and systematically in his essays (in De la Checa a la Meca [Goytisolo 1997] or Crónicas sarracenas [Goytisolo 1998]).

6 "Reader, beware: the narrator is not trustworthy. Beneath his shameless pose of frankness and forthrightness - as his multiple mea culpas and self-accusations come pouring out - he does not scruple for a moment to dupe you" (Goytisolo 1987: 144).

7 "The patient reader of this confused and complicated narrative has every reason to ask himself certain questions concerning its silences, ambiguities, and artful dodges, if, as we fear, he has not already done so” (Goytisolo 1987: 116). 


\subsection{Relato de um certo Oriente}

In 1992 - I was teaching at Munich University then - the publisher Reinhard Piper invited me for a dinner with a Brazilian author whose novel Relato de um certo Oriente had won the "Jabuti"-prize for the year's best novel in his country and was going to be published shortly in German translation. The name of the author pointed to his personal history: Milton Hatoum - born in Manaus in 1952 - did not sound very Brazilian to me then; he is the offspring of a family that had immigrated from Lebanon. At that time, European literary criticism had hardly any information about (nor interest for) the Arabic influence within (Latin) America and its literatures. The extent of this influence has recently been demonstrated by the anthologies of Lautaro Ortiz. ${ }^{8}$ Lebanon, by the way, is the country of origin of the families of a great number of Latin American authors such as Emir Emín Arslán, George Saydah, Rafael Lahud, the poet Al-Karawy (Rachid Salim Al-Juri) in Brazil, and - as the best known - Raduan Nassar.

Relato de um certo Oriente is above all a family saga, a popular and wide-spread genre in Latin America. It evokes the lives and destinies of a family that immigrated from Lebanon to the Brazilian city of Manaus. Motive and beginning of the story is the death of Emilie, the central female protagonist. Some members of the dispersed family return to Manaus for the funeral, among them Hakim, Emilie's son, and the nameless female narrator of the first chapter (of eight in total). Emilie is shown as a mater familias; she used to own the Parisiense, a shop for all sorts of imported goods. The female narrator talks to her absent brother who apparently lives in Barcelona; the reader learns that both of them had been adopted and brought up by Emilie, together with her own four children. The $2^{\text {nd }}$ chapter is addressed to a "tu" which is identical with the female first person narrator of chapter 1, while the personal narrator now proves to be Hakim, Emilie's son. Hakim provides details of the family history (concerning, for example, the suicide of Emir, Emilie's brother, during the emigration). In the $3^{\text {rd }}$ chapter, the perspective changes again. The narrator now is Dorner, a German photographer and a good friend of Emilie's hus-

8 "Según estimaciones no oficiales, existen en la actualidad cerca de 10 millones de árabes -entre descendientes y nativos- habitando los países de América Latina” (Ortiz 2003). 
band (and Hakim's father). This man, nameless throughout the novel, is described as a pious Muslim, attached to the Oriental tradition even in Brazil, reading silently his Koran, isolated from the family. In chapter 4 he is given a voice in the meandering reflections in Dorner's notebooks, revealing - among other things - some secret facts about his immigration. Both Dorner and Hakim function as narrators of the $5^{\text {th }}$ part; the German describes in detail everyday life in Manaus (and also comments on Alexander von Humboldt's cosmic wanderings). In chapter 6, the female narrator of the beginning reappears. Roaming through the unknown quarters of Manaus after Emilie's funeral, she meets Dorner, who transcribes German poems to graphic structures. In chapter 7, a new voice appears: Hindié Conceição, the Native American maid. In the closing chapter 8, the female narrator, who is hospitalized in a sanatorium, reveals that she is the person who compiled these different narrations, transcriptions, and fragments, including her own letters. And there is no proper ending to this story without a proper plot.

This tentative summary leaves out many branches of the stories and emphasizes mainly one characteristic of the novel: the uncertainty of the narrative voices, a feature which it shares with Goytisolo's Paisajes después de la batalla. In order to discover the hemispheric potential of both novels, we will have to look at different complementary contexts: at the historic conditions ("The boom"), the implicit poetics ("The arabesque") and the particular aesthetics ("Remapping the Orient”) of both works.

\section{The boom}

The boom of Latin American literature is a phenomenon of the 1960s and 1970s. ${ }^{9}$ When the first crucial nuevas novelas found their way to the readers, it did not take long for first critical comments on the 'new' Latin American literature to appear. One of the most important voices among these is Carlos Fuentes with his La nueva novela hispanoamericana (Fuentes 1969). Fuentes' study is the first attempt at a systematical description of those 'new' novels which - following upon the success of Cien años de soledad - found their way, conquer-

9 For comments on the boom under the perspective proposed here cf. Vidal (1976) and Levinson (2001). 
ing the international book market, press reviews, and finally the universities. Taking a stance against Alberto Moravia's concept of the death of the novel, Fuentes' essay was born out of the linguistic spirit of the 1960s insofar as it places the nueva novela hispanoamericana at the intersection of structure and change, diachronics and synchronics. To illustrate the spectrum of these innovations, the Mexican critic recurs to four paradigmatic Latin American authors (Mario Vargas Llosa, Alejo Carpentier, Gabriel García Márquez, and Julio Cortázar); the fifth author he uses to prove the impact of Latin American literary innovation lacks one essential requirement: he is not Latin American, but Spanish. He is Juan Goytisolo.

\subsection{Goytisolo - not an author of the boom}

One may wonder why Fuentes included Goytisolo in this honourable pantheon of new Latin American writers. In fact his grandfather used to live in Cuba for a long time, where he acquired wealth as the owner of a sugar factory. More convincing may be Fuentes' own explication that with and in Goytisolo's works the Spanish language had ceased to be the idiom of the colonizers and had become that of the oppressed and the colonized. With a shot of bad intention I have proposed elsewhere that the insight in the inevitable success of Goytisolo's Señas de identidad - this is the novel to which Fuentes refers - had motivated the Mexican critic to declare the Catalan writer a Latin American honoris causa (Ingenschay 2002). If I am right, his speculation turned out to be true insofar as Goytisolo is considered the most important figure in the renovation process of Spanish narrative literature of the second half of the $20^{\text {th }}$ century and at the same time the most severe critic of colonial and postcolonial hegemony in Spain. Yet the speculation is false in relation to that particular aspect of the boom which its critics in particular have underlined: in relation to the literary market. Some authors (Latin Americans, among them Miguel Angel Asturias or - less pronounced - José Donoso) have criticized the boom as a mere strategic plot of the cultural industry of awakening globalisation. The premature identification of boom and magic realism (in the wake of the enormous success of Cien años de soledad) lead internationally to the expectation that all Latin American literature had to mix real and magic elements with a shot of social critique to get 
easy narratives full of overwhelming nature and appealing ThirdWorld autobiographies. This expectation has been caricaturised as McOndismo by a group of young Latin American writers who published a programmatic anthology called McOndo. ${ }^{10}$ We shall see that Goytisolo and Hatoum, in a way very different from that movement, react against a position of cultural hegemony which Néstor García Canclini calls the "macondist fundamentalism" ("fundamentalismo macondista”) (García Canclini 1995).

When locating Goytisolo, the presumable Latin American of the first hour, in this context, it is striking that his works do not comply with the demand for 'magic realities'. Indeed, his great novel Señas de identidad has questioned - according to Fuentes - the "language of the colonizers" and developed a critical position towards Spanish history. In his novels after Señas de identidad, Goytisolo reads Spanish history as a heritage of the Arabic Al Andalús (Goytisolo 1975; 1977; 1983). More recently (and intensely after September 11) he has been dedicating himself to the political and cultural aspects of the 'Orient' in present time on the basis of the traumas of the past (from the expulsion of the Arabic and Jewish population in 1492 up to Franco). And yet his work has remained a hermetic literature for a specialized readership and the very opposite of what characterizes the boom. Goytisolo became Spain's 'national conscience' in Oriental affairs only after the Latin American boom was over. This is a reason why he treats the boom so ironically in a passage of Paisajes después de la batalla titled "Revelations Galore" ("Revelaciones a granel”). In this fragment the narrator speculates whether the wife of the protagonist (who - among so many other things - dedicates himself to a disturbing [and financially unsuccessful] rewriting of Sufí mystic poetry) has not abandoned him meanwhile for a successful Latin American writer.

Tal vez le abandonó hace muchos años por un popular autor latinoamericano que acumula fabulosos royaltis de ocho cifras gracias a su empleo mañoso de la receta narrativa del siglo: el realismo mágico (Goytisolo 1982: 179). ${ }^{11}$

10 The pun of the title was invented by Alberto Fuguet, Sergio Gómez and the group of authors who in the spirit of getting rid of these expectations published the anthology McOndo; cf. Fuguet/Gómez (1996).

11 "Perhaps she has abandoned him long since for an extremely popular Latin American author who has garnered fabulous eight-figure royalties by his clever 
The ironic treatment of Latin American literature and its success in selling Magic Realism as a registered trade mark proves that Goytisolo has distanced himself from the boom by the 1980s. He manifested his distinction by an increasing (and increasingly courageous) Arabization of his own coordinates.

\subsection{Hatoum - not an author of the boom?}

In contrast to the Spaniard Goytisolo, the Brazilian Hatoum fulfilled all preconditions to become an exemplary author of the boom. The cover text of the German edition of Relato de um certo Oriente reads, under the merciless rule of the recipes which turned Macondo into McOndo:

Eine Familiensage vor der farbigen Kulisse des Amazonas, ein Gewebe aus Erinnerungen, vorgetragen von verschiedenen Stimmen: Eindringlich und mit großer Sprachgewalt lässt Milton Hatoum eine "verlorene Melodie” aufleben.

This is not completely wrong, but incomplete and partial. Hatoum's Relato de um certo Oriente is not part of Brazil's 'lost melodies', for they rather belong to the important 'regional literature' which flourishes in the North East of the country. And it is definitely not a variation of the numerous 'Amazonas novels'; nor does it belong to the complex and manifold literature of immigration. Francisco Foot Hardman emphasizes this: "A obra de ficção de Milton Hatoum não se encaixa na rubrica da literatura de imigrantes no Brasil, nem tampouco na linhagem do regionalismo amazônico” (Foot Hardman 2001: 5). ${ }^{13}$ Up to that point I agree with the critic's opinion. Yet, he admits or even demands another label which I consider to be dangerous (if not further defined): that of eroticisation. Exotic appears, according to Foot Hardman, Relato de um certo Oriente "em especial nos países do hemisfério norte (EUA, França, Alemanha, Itália e Portugal [...]) para

use of the narrative recipe of the century: the magic realism” (Goytisolo 1987: 145).

12 "A family saga, put in the colourful setting of the Amazonas, a texture of remembrances, spoken by different voices. With emphasis and great linguistic power, Milton Hatoum revives a 'lost melody"' (Hatoum 1992).

13 "Milton Hatoum's fiction does not fit into the rubric of Brazilian immigrant literature, nor into the line of Amazonic regionalism." 
alguma variante do exotismo nos trópicos" (Foot Hardman 2001: 9), ${ }^{14}$ and he specifies what he means by this tropical exoticism: "Exotismo não só amazônico, mas também orientalista, nas marcas leves desses arabismos que percorrem o texto" (Foot Hardman 2001: 9). ${ }^{15}$

I do not agree with this view, since I take it to assume two different kinds of readership (one Brazilian and another 'Northern'), which leads him to disregard the interplay and the hemispheric construction of Orient and Occident in Hatoum's family saga. 'Put in the colourful setting of the Amazonas', is - beyond this 'orientalist exoticism' - a literary response to intercultural challenges (with Dorner, the German among the Brazilian protagonists, with references to Barcelona as well as to different Latin American settings, and with the presence of remembrance of the Arabic world as a constitutive part of the family history of both the novel's personae and the author himself). The 'slight Arabisms' in Hatoum are not, like the inserted Arabic words in Goytisolo, foreign matter, but constitute a new aesthetics of its own, beyond that of the Latin American boom novel. While Goytisolo has not become a boom author because of his esoteric anti-mainstream 'Arabic turn', Hatoum does not belong to the boom either, and not only because he was late. His exoticism is of a different kind than that of García Márquez and - let us say - Isabel Allende, it is the 'exoticism' of a personally constructed Arabic reference system which is no less vigorous here than Goytisolo's 'political' one. Western imagination, criticism (and some popular knowledge, as we will see below) have characterized this poetic system with a word that recalls its origin in the Orient, the notion of the arabesque.

\section{Arabesque}

On the web, there is a geocities-homepage which under the title "arabesquevirtualalcazar" defines for a public presumably not composed of literary scholars what an arabesque is:

Arabesque is a cultural motif, a virtual place, a spiritual labyrinth, the history of a mosaic of cultures.

14 "[...] above all in countries of the Northern hemisphere (U.S.A., France, Germany, Italy and Portugal [...]) for some variation of tropical exoticism".

15 "Exoticism not only of the Amazonas, but rather orientalist, within the slight marks of those Arabisms all over the text". 
Here is the frame story within the frame story of a splendid blend of lore, science, philosophy, arts and crafts, music and poetry which irradiated from

AL-ANDALUS

on the European continent,

enriching and inspiring the Western world.

Beauty of form and refinement of spirit. [...]

In the beginning was the poem ARABESQUE $[\ldots]^{16}$

Especially in the last line of this quotation the strange character of this explication becomes apparent; here, the Romantic conception of the arabesque (as a poetical force) is mixed with its historical origin in $\mathrm{Al}-$ Andalús. Critics in literary and art history have explained the notion of the arabesque through its etymology, stressing that the notion originally referred to the ornamentation of Arabic art. More recent literary studies occasionally return to this aspect: For example, Gerhart von Graevenitz' fundamental study on the arabesque in Goethe (Graevenitz 1994) takes its departure from the West-Östlicher Diwan, from that collection that - more than any other literary work - contributed to an appreciation of the Oriental world (even if it was an artificially constructed rather than a personally experienced Orient). Yet it is not Goethe - in spite of his article "On Arabesques" ("Von Arabesken") ${ }^{17}$ - who introduced the arabesque as a crucial category of narrative poetics, but a man obsessed with the spiritual power of the Orient: Friedrich Schlegel. Already in his early critical period, ${ }^{18}$ in the famous "Letter about the Novel" ("Brief über den Roman"), he distinguishes between 'high poetry' and the arabesque when he argues that Diderot's Jacques le Fataliste is not high literature, but 'only' an arabesque. Nevertheless, these 'low' arabesques will occupy Schlegel for decades, and moreover they prove to be 'true testimonies', inspiring his entire theory of the novel, as Polheim's exhaustive book on

16 <http://www.geocities.com/peruzele/arabesquevirtualalcazar.html?200512> (May 14, 2005).

17 Published in 1798 in Wieland's Teutscher Merkur. With his references to Raphael and to Pompeian decorative painting, Goethe still owes much to the idea of the arabesque as a category of visual arts; the same is true for Karl Philipp Moritz' chapter on the arabesques in his Vorbegriffe zu einer Theorie der Ornamente (1793).

18 For details on the use of the term and its development and on theoretical implications of the arabesque cf. Polheim (1966). 
Schlegel's arabesque was the first to show. In "Letter about the Novel”, Schlegel writes:

If such examples became known, then I would have the courage for a theory of the novel which would be a theory in the original sense of the word; a spiritual viewing of the subject with calm and serene feeling, as it is proper to view in solemn joy the meaningful play of divine images. Such a theory of the novel would have to be itself a novel which would reflect imaginatively every eternal tone of the imagination and would again confound the chaos of the world of the knights. The things of the past would live in it in new forms [...]. These would be true arabesques which, together with confessions, [...] are the only romantic products of nature in our age (Schlegel 2003: 294).

'Product of romantic nature', in Schlegel's diction, is a somewhat chaotic and at the same time reflective world of Romanesque discourse in which theory and practice of the novel merge. Today, we would qualify such a texture as metaliterary and intertextual. 'Arabesque' would be, then, rather than a modern, a post-modern category. Under various aspects, in particular with regard to narrative technique, both novels, Goytisolo’s Paisajes después de la batalla and Hatoum's Relato de um certo Oriente, match such a definition.

\subsection{Goytisolo's arabesque}

The appearance of some Arabic words and signs in the flow of Goytisolo's Paisajes después de la batalla is not primarily a characteristic of the arabesque, but rather due to the unreliability of the narrator. Throughout the text, meta-literary reflections interrupt the coherence of the fictional narrative. The novel's systematical variation of polyphony and dialogicity is not a post-modern commonplace, but part of a special poetics which Goytisolo developed himself in his previous novel Juan sin tierra. The most convincing argument for calling this poetics arabesque is that Goytisolo explicitly recurs to that notion in its etymological sense, when relating his writing to architecture and to the ornamental combinations of symmetrical configurations:

Eliminar del corpus de la obra novelesca los últimos vestigios de la teatralidad [...] sustituyendo la progresión dramática del relato con un conjunto de agrupaciones textuales movidas por fuerza centrípeta única [...] improvisando la arquitectura del objeto literario, no en un tejido de relaciones de orden lógico-temporal, sino en un ars combinatoria de elemen- 
tos (oposiciones, alternancias, juegos simétricos) sobre el blanco rectangular de la página (Goytisolo 1975: 13). ${ }^{19}$

As a post-modern theory of the arabesque meta-novel, Paisajes después de la batalla draws on all registers of intertextuality. Hypertexts are the works of Lewis Caroll, Aragon, Genet, Cortázar; the most important ones for our context are Borges' Ficciones and the mystic Sufí poetry of Jalal ad-Din Rumi. More clearly than in Paisajes después de la batalla, the Arabic elements inserted into Juan sin tierra point to a narrative structure that defines itself explicitly as different from 'Western' forms of thought and discourse. In this sense it is important that the unpleasant hero not only writes pornographic messages and political pamphlets in his mansard, but also dedicates himself to copying 'in finest calligraphy' the divans of Jalad ad-Din Rumi. Whereas Goytisolo later will choose the poems of Ibn al-Farid as a central intertext (in his novel Las Virtudes del pájaro solitario [1988 and 1991]), he uses some "Nasibs" (a special form of Sufí love poems) in Paisajes después de la batalla. They appear distorted insofar as 'our hero' addresses them to his unloved wife living in the flat next door. The end of the Sufí poem, as it appears rewritten in the novel, unfolds not only the idea of simultaneity, but also that of two lives being lived in two different worlds at the same time:

Todos los pájaros de brillante pluma se morderán de envidia el corazón, en el lugar donde reiremos tú y yo.

Esta es la maravilla mayor: que sentados acá, en el mismo escondrijo, vivamos simultáneamente en el Irak y en Jorastán tú y yo (Goytisolo 1988: 87). ${ }^{20}$

This simultaneous life in two worlds resonates with Hatoum's Relato de um certo Oriente, when Hakim, Emilie's son, declares to live in

19 "To eliminate from the corpus of the narrative work the last traces of theatricality [...], replacing the dramatic progression of the story with an assembly of textual groupings moved by unique centripetal force [...] improvising the architecture of the literary object, not in a texture of relations of logical-temporal order, but in an ars combinatoria of elements (oppositions, alternations, symmetrical plays) on the rectangular white of the page”. The translation of Helen Lane was not accessible, the translation is mine (D. I.).

20 "All the bright-plumed birds will feel in their hearts the bite of envy, in the place where we will laugh,/ you and I.// This is the marvel of marvels: that sitting here, in the same hiding place, we are at one and the same time living in Iraq and Khurasan,/ you and I" (Goytisolo 1991: 68). 
two different languages and thus in two worlds: "Desde pequeno convivi com um idioma na escola e nas ruas da cidade, e com um outro na Parisiense. E às vezes tinha a impressão de viver vidas distintas” (Hatoum 1989: 52). ${ }^{21}$

\subsection{Hatoum's arabesque}

We saw that Hatoum's novel, too, operates with a multitude of undefined narrators which are unified in the end, in chapter 8 , by the voice of the anonymous female narrator. ${ }^{22}$ As she fails in controlling the complete narration of this certain Orient - Relato de um certo Oriente - she corresponds only partly to Sheherazade. Like the narrative voice of the Arabian Nights, the power of the narrating persona safeguards her discursive supremacy as well as her survival, yet - unlike the collection of fairy tales - the present novel offers only one out of many possible constellations or stories. Hatoum aims first and foremost at an approximation to a certain Orient, exactly as Borges described his dedication to the Orient as an approximation to a (geographically) nonexistent place. But instead of discussing Borges' influence in this work, I would like to come back to Foot Hardman's characterization of Relato de um certo Oriente as "orientalist exoticism", a concept for which he does not provide any further definition. The poetics of an open narrative which takes a certain form, but which could also be different, is one central aspect of Hatoum's work, and the reference to the Arabian Nights is another. The lack of reliability in this story, again, can be read as a poetics turned against the aesthetics of the boom, more specifically against García Márquez’ family saga of the Buendía, where the whole development of the story proves to depend on Melquíades' wise vision, written down in his foundational Sanskrit text. Beginning already on the first pages, Cien años de soledad refers to biblical intertexts, from the Garden of Eden to the Apocalypse. In Relato de um certo Oriente, however, the decisive

21 "From the time I was small I inhabited one language in school and on the streets and another in the Parisiense. Sometimes I felt as if I were living two distinct lives" (Hatoum 2004: 56).

22 Lamentably the English translation ads the names of the persons speaking as headlines to the respective chapters; this does not correspond to the original text nor, I guess, to its intention. 
model for the narrative is not the Bible, but the Koran and the family constellation of Mohammed evoked by Emilie's husband:

Emilie e o marido praticavam a religião com fervor. Antes do casamento haviam feito um pacto para respeitar a religião do outro, cabendo aos filhos optarem por uma das duas ou por nenhuma.

- Basta olhar para o templo que abriga os fiéis de cada religião para se ter uma idéia de como uma difere da outra - disse teu pai, ao explicar a árvore genealógica da família do Profeta (Hatoum 1989: 69).

While Mohammed's genealogy seems to be one point of reference for this saga, the Koran is one important intertext, together with the Arabian Nights. Dorner establishes a sort of metonymic relation between his friend, Emilie's husband, and the Arabian nights, according to Borges the book that stands at the beginning of the awareness of the Orient:

O convívio com teu pai me instigou a ler As mil e uma noites, na tradução de Henning. A leitura cuidadosa e morosa desse livro tornou nossa amizade mais íntima; por muito tempo acreditei no que ele me contava, mas aos poucos constatei que havia uma certa alusão àquele livro, e que os episódios de sua vida eram transcrições adulteradas de algumas noites, como se a voz da narradora ecoasse na fala do meu amigo (Hatoum 1989: 79). ${ }^{24}$

Emilie's husband not only appears as the typical unreliable narrator you do not believe, he is so by identification with the Arabic fairy tales. The extent to which Islamic thought is present in his experience of the world becomes apparent in his description of his emigration to Brazil as a "hadji". However, the omnipresence of 'Oriental' elements is not restricted to this character, reading the Koran and smoking his

23 "[Emilie and her husband] were both fervently religious. Before they got married, they made a pact to respect the other's faith and to let their children opt for one or the other or none at all.

'All you have to do is look at the architecture of their places of worship to see the difference between the two religions', said your father in the midst of an explanation of the Prophet's genealogical tree one late afternoon in the Parisiense" (Hatoum 2004: 79).

24 "My friendship with your father prompted me to read A Thousand and One Nights, in Henning's translation. My slow and careful reading of that book brought us closer: for a long time I didn't believe what he told me, but gradually I realised there were certain allusions to the book, and that some of the episodes of his life were adulterated transcriptions of certain of the tales, as if the voice of the narrator were echoing in my friend's words” (Hatoum 2004: 93). 
narguilé. Emilie's entire house is filled with tapestry from Isphahan and pieces of Lebanese cedar wood, and so is her legendary shop, where the conversations are in Arabic ("A conversa era exlusivamente em árabe” [Hatoum 1989: 58]).

Intertextual links and the implied poetics are the two fields where the arabesque becomes palpable. While Goytisolo chooses esoteric Sufí poetry as one of his points of reference, Hatoum refers with the Arabian Nights, to a more popular cardinal intertext. Yet both authors use these intertexts to demonstrate the limits of communication, which they question further by multiple unreliable narrators. Both use the novel as means of meta-literary reflection, and both provide a new perspective on the city in which the action is set.

\section{4. 'Oriental' Remappings}

\subsection{Moving within the city}

On the inside cover of the 1982 edition of Paisajes después de la batalla, we find a reproduction of the Paris Metro map. The city's legendary subway is one of the few reliable means of orientation in the deEuropeanized urban setting. Paris, hybridised by huge immigration movements, is only one paradigm of this postmodern, postcolonial situation, as one of the descriptive and meta-discursive observations in Goytisolo's text shows:

El hormigueo de la calle, su frondosidad creadora, le procuran diariamente un espectáculo continuo, variado y gratuito. En la Rue d'Aboukir o la Place du Caire, como en la Porte de Clignancourt o la Goutte d'Or, saborea la presencia fluida e incesante del gentío, su movilidad desordenada, su diáspora febril por la rosa de los vientos. La paulatina deseuropeización de la ciudad -la emergencia de zocos y hammams, venta ambulante de totems y collares, pintadas en árabe y turco- le colma de regocijo. La complejidad del ámbito urbano -ese territorio denso y cambiante, irreductible a la lógica y programación-, invita a cada paso a trayectos versátiles, a que tejen y destejen, lienzo de Penélope, una misteriosa lección de topografía. [...] Nuestro excéntrico personaje ha advertido que no es necesario coger el avión de Estambul o Marrakech en busca de exotismo: basta salir a estirar las piernas para topar inevitablemente con él (Goytisolo 1982: 108-109). ${ }^{25}$

25 "The antlike hustle and bustle of the street, its creative vegetable luxuriance offer him each day a continuous, free variety show. In the Rue d'Aboukir or the Place du Caire, as at the Porte de Clignancourt or the Goutte d'Or, he savors the fluid, 
Strangely enough, the opening metaphor of the anthill (cf. the original version) can also be found in Hatoum's novel (Hatoum 1989: 128). Even more interesting is the last sentence of the quotation above, as it underlines that exoticism can not only be found in Hatoum's Amazon setting of Manaus, but in every modern metropolis, for example in the city of Paris, described by Benjamin as the prototypical capital of the $19^{\text {th }}$ century. The unpleasant flâneur in Paisajes después de la batalla, roaming through the Arabized quarters, is merely a cipher for any person moving through a metropolis "[e]xaminando el plano, guía de metro o nomenclatura de las calles de alguna ciudad: Paris Nueva York Berlín El Cairo Estambul Ámsterdam” (Goytisolo 1982: 41). ${ }^{26}$ This is why I proposed to read Paisajes después de la batalla as a specific (provisionally 'ultimate') form of literary discourse on Paris (Ingenschay 1997).

Even if Manaus is not Paris, Relato de um certo Oriente shares some of the characteristics of a city novel, and Foot Hardman applies the idea of the metropolitan maze also to Manaus and its harbour. ${ }^{27}$

permanent presence of the crowd, its chaotic Brownian movements, its feverish diaspora toward every point of the compass. The gradual de-Europeanization of the city - the appearance of Oriental souks and hammams, peddlers of African totems and necklaces, graffiti in Arabic and Turkish - fills him with rejoicing. The complexity of the Urban environment - that dense and ever-changing territory irreducible to logic and to programming - invites him on every hand to evershifting itineraries that weave and unweave themselves, a Penelope tapestry, a mysterious lesson in topography. [...] Our eccentric character has found that it is not necessary to take a plane to Istanbul or Marrakech in search of exoticism: he need only step outside to stretch his legs for a bit to stumble inevitably upon it" (Goytisolo 1987: 85-86).

26 "Absorbed in contemplation of the map, the subway guide, or the street names of some city: Paris, New York, Berlin, Cairo, Istanbul, Amsterdam” (Goytisolo 1987: 28).

27 Foot Hardman projects the descriptive inventory of the metropolis onto the Manaus:

“[...] laberinto que é dos trens e navios saindo de tão distantes mundos, os novos selvagens invadindo o Tâmisa, o Sena, o Solimões, mudando a cara dos habitantes de Londres-Paris ou de Manaus-Belém, ou de San Francisco-Nova Iorque, ou de São Paulo-Rio de Janeiro, ou de Recife-Salvador, cidades cosmopolitas porque talvez também norte-americanas, africanas, asiáticas, árabes, latinas, judaicas, Manaus de Zona Franca e franca falência cristo-maometana, índias putas batizadas, havendo ainda lugar para esses lírios de toda memória melancólica que imita a grande arte roubada dos primeiros contadores de histórias" (Foot Hardman 2001: 12). 
When in chapter 6 the female narrator of the first part leaves for a long walk through the unknown districts of the city, Manaus becomes another protagonist of the novel:

Atravessei a ponte metálica sobre o igarapé, e penetrei nas ruelas de um bairro deconhecido. Um cheiro acre e muito forte surgiu com as cores espalhafatosas das fachadas de madeira, com a voz cantada dos curumins, com os rostros recortados no vão das janelas, como se estivessem no limite do interior com o exterior [...]. [...] Havia momentos, no entanto, em que me olhavam com insistencia: sentia um pouco de temor e de estranheza, e embora um abismo me separasse daquele mundo, a estranheza era mutua, assim como a ameaça e o medo. E eu não queria ser uma estranha, tendo nacido e vivido aqui. Procurava caminar sem rumo, não havia ruas paralelas, o traçado era uma geometria confusa, e o rio, sempre o rio, era o ponto de referência, era a praça e a torre da igreja que ali inexistiam. Passei toda a manhã naquele mundo desconhecido, a cidade proibida na nossa infancia, porque ali havia duelo entre homens embriagados, ali as mulheres eram ladras ou prostitutas, ali a lâmina afiada do terçado servia para esquartejar homens e animais (Hatoum 1989: 123). ${ }^{28}$

As this passage continues, the gleaming light of the sun dazzles this female flâneur, disturbs her perceptions, and she realizes that she has the impression that she is walking on a mountain of garbage (Hatoum 1989: 124). The city appears unreal not only to her, but as well to

(“[...] it is a labyrinth of trains and boats coming from distant worlds, the new savages invading the Thames, the Seine, the Amazon, changing the face of the inhabitants of London-Paris, or of Manaus-Belém, or San Francisco-New York, or São Paulo-Rio de Janeiro, or Recife-Salvador, cosmopolitan cities, perhaps because they are also North American, African, Asian, Arab, Latin and Judaic. Manaus, Free Trade Zone and Christian-Moslem moral bankruptcy, baptized Indian whores, and still with space yet for all those lilies of melancholy memoirs imitating the high art stolen from the first story-tellers").

28 "As soon as I crossed the metal bridge over the creek and entered the narrow streets of an unfamiliar neighbourhood, I was met by the gaudy colours of the wooden houses, a strong, acrid smell, and the singsong voices of street kids, their faces cut-outs in the open window holes, at the very border itself (a warped and colourless frame) meant nothing to those faces staring into space [...]. There were other moments when the faces stared back at me urgently, making me feel shy and a little scared, and even with the abyss that existed between us the strangeness was mutual-likewise the threat and the fear. I didn't want to feel like an intruder, having been born and grown up here. I was trying to wander aimlessly, but there were no parallel streets; the design was a confused geometry, and the river, always the river, was the point of reference, instead of the square and the church spire of our neighbourhood. - I spent the entire morning in the city forbidden to us as children, where there were duels between drunken men, where the women were either thieves or prostitutes, where blades sharpened on machetes were used to carve men as well as beasts” (Hatoum 2004: 150-151). 
Dorner, the photographer. When he comes back from a trip to the inner regions, he perceives Manaus as an 'urban perversion' and both the city and the jungle as 'two lies, separated by the river' ("e ao retornar afirmava ser Manaus uma perversão urbana. 'A cidade e a floresta são dois cenários, duas mentiras separadas pelo rio'” [Hatoum 1989: 82]). Dorner and the nameless young woman - in their accounts of a certain Orient - and 'our protagonist' in Goytisolo's Arabized Paris share the risk of disorientation in their respective cities, just as the readers get lost in the incoherent fragments of Paisajes después de la batalla and the ambiguous narrative voices in Relato de um certo Oriente. Would it be too far a stretch to argue that both novels combine the search for orientation with the search for literalising the Orient?

Rodolfo Mata reminds us of a short text Borges wrote in the 1930s ("Del rigor de la ciencia”, "The rigor of science”), in which imperial cartographers develop their craft of drawing maps to such a degree of perfection that their models finally become coextensive with the land itself. Mata compares this parabola to Hatoum's novel and to the need for orientation already indicated in its very title (Mata 1996: 101). Yet, it is not Hatoum, but Goytisolo who in his literary remapping of Paris refers directly to Borges. The fragment in which the metro net is used to explain utopia, literary fiction, and fabulation, is entitled "En el Paris de los trayectos que se bifurcan" ("In the Paris of the Forking Paths"), a clear pastiche of Borges' famous story "El jardín de los senderos que se bifurcan": The description of the concrete "forking paths' in Paris ("Ramificaciones, encrucijadas, pasajes, trayectos de una sola dirección, desvíos, parábolas, media vueltas, elipses, cuppos di sacco" [Goytisolo 1982: 110]), ${ }^{29}$ shifts immediately to the metalevel of the constitution of fictional discourse:

Examinar el plano del metro es ceder al recuerdo, evasión, desvarío; abrirse a la utopía, la ficción y la fábula: recorrer los monumentos, abominaciones y horrores de la ciudad, los monumentos, abominaciones y horrores propios, sin necesidad de moverse de casa (Goytisolo 1982: $110) .{ }^{30}$

29 "Ramifications, intersections, connecting points, one-way-journeys, roundabout itineraries, parabolas, half circles, ellipses, dead ends" (Goytisolo 1987: 87).

30 "To examine the map of the metro system is to yield to memory, to escape, to delirium; to accept utopia, fiction, fable: to visit the monuments, the abomina- 
Borges' theory of selection and orientation inspire Goytisolo's perception of the city, and in a very concrete way the Ficciones, with their puzzles and game-like quality, are the model behind Goytisolo's arabesque poetics.

Though Hatoum does not very explicitly refer to the stories of the Argentinean author as intertext, ${ }^{31}$ he declares his entire novel to be the approximation to a certain Orient, and thus it seems to be justified to read it as a direct comment on Borges' essay on the Arabian Nights.

\subsection{Major or minor hemispheric constructions?}

Even if Goytisolo includes, besides the Arabic text lines, some Turkish fragments in Paisajes después de la batalla, ${ }^{32}$ and even if Emilie is said to invent her own hybrid language, ${ }^{33}$ both novels are written in widespread and well-known languages. This is also true for Kafka's work, and yet Deleuze/Guattari use him as the paradigm for their theory of a "minor literature", defined as the writing of a minority in a major language. When Deleuze/Guattari argue that in such a minor literature everything is political, they refer to the 'Scheme of minor literatures' that Kafka wrote down in his diary in 1911. Here, the young author writes about the conflict between father and son and that he might turn this conflict into a literary subject. The parallel to Goytisolo's increasing distance to Spain and the tension between the Christian mother and the Islamic father in Relato de um certo Oriente are decisive aspects for a reading of these works as minor literature. Deleuze/Guattari understand the family conflict mentioned by Kafka not as a reference to an oedipal fantasy, but as the expression of a political program. Seen from this perspective, we notice that Goytisolo in his political discussion of Spanish history since Señas de identidad has increasingly turned away from Eurocentric thought and discourse. Fuentes' characterization of Goytisolo's writing matches in a significant way the definition of the revolutionary power of the minor

tions, the horrors of the city, one's own monuments, abominations, and horrors, without ever having to leave home" (Goytisolo 1987: 87).

31 For the very few and hidden hints cf. Mata (1996).

32 The text was written while Goytisolo stayed in Berlin with a fellowship of the German Academic Exchange Service; it alludes to the multicultural "Istanbul on Spree".

33 Cf. Hatoum (1989: 166); about this: Mertin (1993). 
literature in Deleuze/Guattari. When they state that "[t]here is nothing that is major or revolutionary except the minor. To hate all languages of masters" (Deleuze/Guattari 1986: 26), Fuentes writes in a similar gesture: "Con Goytisolo, el español escrito en España deja de ser el lenguaje de los señores para revelarse, [...] como el lenguaje de los parias" (Fuentes 1969: 82). ${ }^{34}$

As parias, or rather as marginalized writers in the current literary landscape, Goytisolo and Hatoum, as we stated above, have not become writers of the boom. The reason for this is their orientation towards the Arabic world, with the consequence that the discourse they invented and cultivated does not fit into any cultural imagination that separates continents. The success story of Latin American literature has fought against centuries of hegemonic cultural Eurocentrism, but in doing so it has privileged a monolithic image of Latin America. Yet it would be completely erroneous not to recognize that the Orient and its artistic/cultural appropriations occupy traditionally a far more prominent place in Western imagination than Latin America. Again: Goytisolo and Hatoum are not 'orientalists' in the Saidian sense, they are rather reacting against the Western construction of the Orient. Recently, Christina von Braun modified Said's historic arguments, explaining that the so-called Occident needs and will need in future times the Orient for its own permanent self-definition (Braun forthcoming). 'Identity by exclusion' seems to be the working principle then. Against such an 'exclusive' orientalism, Goytisolo and Hatoum create their hemispheric construction of a discourse that unmasks Western thought as merely another alterity. Their ArabAmerican projects seek to deterritorialize both the European hegemony and the Latin American exclusiveness.

\section{Bibliography}

Borges, Jorge Luis (1980): “Las Mil y una noches”. In: Siete Noches. Epílogo de Roy Bartholomew. México/Buenos Aires: Fondo de Cultura Económica, pp. 57-74.

Braig, Marianne/Ette, Ottmar (2005): “Presentación”. In: Iberoamericana, “Dossier: Construcciones hemisféricas” V, 20, pp. 83-84.

34 "With Goytisolo, the Spanish written in Spain ceases to be the language of the masters and proves to be $[. .$.$] the language of the parias".$ 
Braun, Christina von (forthcoming): "The symbol of the Veil in Transcultural Phantasy".

Deleuze, Gilles/Guattari, Félix (1986): Kafka. Toward a Minor Literature. Transl. Dana Polan. Minneapolis: University of Minnesota Press.

Foot Hardman, Francisco (2001): “Morrer em Manaus: os avatares da memória em Milton Hatoum”. In: Têmpo Brasileiro 141, pp. 5-15.

Fuentes, Carlos (1969): La nueva novela hispanoamericana. México: Joaquín Mortiz.

Fuguet, Alberto/Gómez, Sergio (1996) (eds.): McOndo. Barcelona: Grijalbo/Mondadori.

García Canclini, Néstor (1995): Ideología, cultura y poder. Buenos Aires: Universidad de Buenos Aires/Oficina de Publicaciones Ciclo Básico Común.

Goytisolo, Juan (1975): Juan sin tierra. Barcelona: Seix Barral.

- (1977): Juan the Landless. Transl. Helen R. Lane. New York: Viking Press.

- (1982): Paisajes después de la batalla. Barcelona: Montesinos.

- (1983): Makbara. Barcelona: Seix Barral.

- (1987): Landscapes after the battle. Transl. Helen Lane. New York: Seaver Books.

- (1988): Las virtudes del pájaro solitario. Barcelona: Seix Barral.

- (1991): Virtues of the Solitary Bird. Transl. Helen Lane. London: Serpent’s Tails.

- (1997): De la checa a la Meca. Madrid: Alfaguara.

- (1998): Crónicas sarracenas. Madrid: Alfaguara.

Graevenitz, Gerhard von (1994): Das Ornament des Blicks. Über die Grundlage des neuzeitlichen Sehens, die Poetik der Arabeske und Goethes West-Östlichen Diwan. Stuttgart/Weimar: Metzler.

Hatoum, Milton (1989): Relato de um certo Oriente. São Paulo: Companhia das Letras.

- (1992): Emilie oder Tod in Manaus. Transl. Karin von Schweder-Schreiner. Munich: Piper.

- (2004): Tale of a certain Orient. Transl. Ellen Watson, rev. John Gledson. London: Bloomsbury.

Huntington, Samuel (1996): The Clash of Civilizations and the Remaking of World Order. New York: Simon \& Schuster.

Ingenschay, Dieter (1997): “Am Ende von Paris? - Der Stadtmythos im peripheren Blick”. In: Schulz-Buschhaus, Ulrich/Stierle, Karlheinz (eds.): Projekte des Romans nach der Moderne. München: Fink, pp. 149-171.

- (2002): "Carlos Fuentes y Juan Goytisolo: Boom, trauma histórico y postcolonialidad. La trayectoria de una relación transatlántica”. In: Ingenschay, Dieter/Knauer, Gabriele/Meyer-Minnemann, Klaus (eds.): El pasado siglo XX. Una retrospectiva de la literatura latinoamericana. Berlin: edition tranvía, pp. 92111.

Levinson, Brett (2001): The ends of literature: the Latin American 'boom' in the neoliberal marketplace. Stanford: University of California Press. 
Martín Morán, José Manuel (1987): “Paisajes después de la batalla. La verdad, la ficción y el vacío”. In: VVAA: Escritos sobre Juan Goytisolo. Coloquio en torno a la obra de J. Goytisolo. Almería: Instituto de Estudios Almerienses, pp. 147167.

Mata, Rodolfo (1996): “El Oriente de una Novela”. In: Remate de Males 16, pp. 101108.

Mertin, Ray-Güde (1993): “Ein anderer Orient: Anmerkungen zu den Romanen Lavoura arcaica von Raduan Nassar und Relato de um certo Oriente von Milton Hatoum”. In: Lusorama 22, pp. 5-18.

Ortiz, Lautaro (2003): “El mundo árabe en Latinoamérica”. In: Ortiz, Laurato (ed.): Árabes 1. Poemas, crónicas y relatos en Sudamérica. Buenos Aires: ed. Desde la Gente/Ediciones Instituto Movilizador de Fondos Cooperativos.

Polheim, Karl Konrad (1966): Die Arabeske. Ansichten und Ideen aus Friedrich Schlegels Poetik. München/Wien/ Paderborn: Schöningh.

Said, Edward (1978): Orientalism. New York: Pantheon Books.

Schlegel, Friedrich (2003): "Letter about the Novel”. In: Bernstein, J. M. (ed.): Classic and Romantic German Aesthetics. Cambridge: Cambridge University Press, pp. 287-296.

Vidal, Hernán (1976): Literatura hispanoamericana e ideología liberal, surgimiento y crisis (Una problemática sobre la dependencia en torno a la narrativa del boom). Buenos Aires: Ed. Hispamérica. 



\section{Alberto Mussa \\ Who is Facing the Mirror?}

Since my early adolescence, when I learned that I was an Arab descendant on the paternal line, I had been trying to understand what that exactly meant, what was the character of the substance that made it different from my Brazilian portion I inherited from my mother. For it was easy to understand a certain singularity in the Arabic style of being because people who learned I was a grandchild of Arabs hoped to see something of that style in me.

I had three mirrors to find that identity: the image the Brazilians made of the Arabs, the image my family made of itself, and the image emerging from books.

In the image of the first mirror and in public opinion, the concepts of Arab and Muslim were easily confused. And besides being Muslims, all Arabs ran small businesses. And they were greedy. And they were not Arabs but Turks. For it was with Ottoman passports that the first Syrian and Lebanese immigrants arrived in Brazil without being particularly desired, unlike European immigrants, whose arrival was financially encouraged by the government.

Well, my family was Christian. Incidentally, all the Arab families I knew were Christian. This meant that I was only half an Arab. And half a Christian, because we were orthodox Christians, not very much accepted nor understood by Catholics.

In addition, the character of a tight-fisted hawker, an exploiter of the poor, someone who charges too much when selling for cash and abuses interest rates when selling by instalments never befitted my personal history. My grandfather was a poet whose house was full of bookshelves standing at every wall. My father, being an erudite man, used to leave the car outside because even the garage was a book storage. My great-grandfather, I was told, had founded a school and was the owner of the largest library in Lebanon.

Thus, I preferred to look for the second alternative, the family mirror. My grandfather especially represented that mirror. He was immensely proud of being an Arab (more than actually being Lebanese). 
For two reasons: Arabs, according to him, were a people of fundamental significance in the history of mankind, had dominated all sciences and were directly responsible for the development of Europe.

Being Brazilian (he told me), I could see the signs of Arab civilisation in my own language because the Arabs dominated the Iberian Peninsula for eight centuries and had brought the culture, the beauty and the sciences to that region. When I said álgebra, alquimia, açúcar, azeite, azar, mascate, almofada, arroz (and arroz-com-feijão is a typical Brazilian meal), I was actually speaking Arabic words representing concepts or elements of civilisation brought to the Iberian Peninsula by the Arabs.

Another source of Arab pride, according to my grandfather, was the language: Arabic was the richest and most beautiful in the world. Because each word had a vast number of synonyms. Because it was written with the prettiest script. And because it had a unique poetry, which was inaccessible to me. Nevertheless, instead of teaching me this Arabic, he encouraged me to love Portuguese because I would only be a real Brazilian if I spoke the language of my homeland perfectly, just as he was only an Arab because he loved the language of his ancestors.

Although this enthusiasm fascinated me, I could not accept that image as mine: firstly because I did not speak any Arabic; secondly because that brilliant civilisation to which the Iberian cultures owed so much was the work of Muslims. And it was the Muslims who - as far as I was told - had persecuted the Christians of the east.

Then I heard quite frequently from my father and many uncles (and I have to say that I still hear the same theory today) that Arab Christians, more specifically Lebanese Christians, were not Arabs in the narrow sense of the word. In fact, they were Phoenicians forced to speak the language of the Muslim invaders who subjugated them.

At that time, being a Phoenician was completely unimaginable to me. I could not hear the Phoenician language; I did not eat any Phoenician food; I did not dance any dance nor did I sing any songs that were Phoenician. Even if the Phoenicians had been as glorious as the Arabs (also because they invented the alphabet) their glory was much more distant and diffuse. It was not interesting to be a Phoenician because the Phoenicians had not had anything that was especially theirs and, maybe mostly, because they had been battered, had disappeared. 
Thus I grew up with the sensation of having descended from an ethnic group without a face, without its own identity, whose history told me little and which was very distant from me. All that was left to me was my Brazilian side. And the Brazilians did not recognise us Turks, one of the roots forming their identity.

During this process - and I would like to point out that it happened in my adolescence - I also remembered the image of the third mirror, that of books. Apart from the oriental poems and stories I had come across accidentally and which were quite common in Western literature, there were two fundamental texts: The Arabian Nights (which today is a part of world literature whose influence on the Western imagery is immeasurable) and The man who calculates, a novel by Júlio César de Mello e Souza, who attributed the authorship of his books to a fictitious Arab called Malba Tahan.

Though he was not a descendant of the Syrians or the Lebanese, Malba Tahan, a Brazilian professor of mathematics, wrote a vast work composed mainly of oriental stories, mostly Arabic, and some novels such as Salim, the magician and The man who calculates, his most famous book.

The man who calculates tells the story of a Persian sage who travels around the world solving strange mathematical problems proposed to him, until he falls in love with a Christian slave and converts to Christianity. Its main difference to The Arabian Nights is its lack of erotic and supernatural components. It has, however, a similar structure with a chain of independent stories favouring the exceptional, the uncommon, the odd, the outstanding.

The writings of Malba Tahan address the young public and are founded on fundamental moral values, the quest for knowledge and the practice of generosity in particular. Beremiz Samir, the man who calculates, is intelligent, generous, prudent, forgiving, good. And Beremiz' morale is based on what in the West is usually called Oriental wisdom.

Strange to say that despite his overwhelming success Malba Tahan had no successors. Fiction with Arabic topics remained limited to translations of the Nights and to his novels. Even if I could extract an image from these readings that corresponded to that depicted by my father and my grandfather - because the characters of Malba Tahan were wise and decent men who loved knowledge - there would still be 
the impression that this universe was not part of me, since it was a basically Muslim universe.

I entered adult life having lost my father and my grandfather. By then, I no longer felt I needed to look for an Arab identity as I considered myself Brazilian. And it was not only because of my mother's descent. It was mainly because I spoke Portuguese, listened to samba, attended Afro-Brazilian cults, ate rice-and-beans, played capoeira (a Brazilian kind of martial art), watched football matches and attended the carnival.

And this did not happen only to me. All the Turks and their descendants were completely integrated into Brazilian life. While the few Muslims among them could still be distinguished by practising a different religion, the Christian majority's only distinctive feature was an Arab name, as if it were a label. And the custom of eating quibe, taboule, chancliche and vine leaves. Thus I saw all these names scattered in all segments of Brazilian life: from Zaquia Jorge, the popular actress or Hélio, "the Turk", a samba composer, to people from the upper middle class such as the journalist Ibrahim Sued or the trader Khalil Gebara. And there were many others: in football, in medicine, in films, in politics, in carnival, in industry.

There was one thing that always roused my attention: the large number of Turks among the great masters of the Portuguese language - Said Ali, Evanildo Bechara, Antonio Houaiss. It seemed to me that in a way they had all heeded my grandfather's advice and that the devotion for the Portuguese language represented definitive integration into the new world of the Americas.

In literature, however, there was no such diversity. The stereotype of the tight-fisted and unscrupulous Turk, greedy for profit and gain, dominated. Among all the different stereotypical characters of Arab immigrants that Brazilian fiction has produced, nearly all of them secondary, there is one who sticks out: Nacib, the Syrian from the novel Gabriela, clove and cinnamon by Jorge Amado.

In the novel, Nacib is a typical immigrant arriving in Brazil to make his fortune in trade. He establishes a restaurant in Ilhéus, which - in 1925 - lives in the fever of cocoa-exportation. He falls in love with Gabriela, a typical Brazilian girl of mixed blood who works as a cook in his establishment. 
Jorge Amado explores the contrast between two innocent natures: that of Nacib, who believes in Gabriela's love and offers to marry her following the traditional moral pattern, and that of the girl, who walks barefoot, plays like a child, is not ashamed of undressing in front of people and accepts the love of men as if she lived in a world unaffected by the anathema of original sin.

When Gabriela starts living with Nacib as his wife, the Syrian gives her jewellery, fine clothes, expensive shoes (which she has difficulty wearing); he takes her to feasts, tries to show her off in the best society of Ilhéus and wants to lift her to a superior category of woman.

Until the day he finds Gabriela in bed with Tonico Bastos, a lawyer, a kind of Brazilian Don Juan. Then Nacib banishes Gabriela who, innocent and sensual, does not seem to understand the reasons of such turmoil. But Nacib cannot forget her or, better, he cannot give up the erotic pleasure offered by the girl. He takes her back, not as his wife any more, but under the former conditions as his employee. He is happy again because he has got the sexuality of Gabriela for free without worrying about the adultery and because he becomes ever richer (and it is Gabriela who makes the excellent food sold by the Syrian).

Thus Jorge Amado's novel offers a symbol for the Arab immigrant's dilemma: the New World (represented by Gabriela's beauty, eroticism and moral depravity) is a space to be explored (and Nacib ends the book exploring the work and the sexuality of the girl), and never one of affective integration (because Gabriela betrays Nacib).

It was only from the 70s on that Brazilian fiction would produce great works in which the Arab characters moved away from the Turk stereotype. For the first time Arabs spoke about themselves.

In Raduan Nassar's novel Archaic farming, André, the son of Arab immigrants living on a farm, leaves home suffocated by the rigid authority of his father and with a strong sense of guilt because of his incestuous relation to his sister Ana. Pedro, the elder brother, sent by his mother, finds André and takes him back. André appears remorseful and their father decides to have a celebration. It is at this occasion that an unexpected tragedy occurs: during Ana's - very sensual - dance (seeming to insinuate herself to André), their father guesses the incest, takes a big knife and stabs his daughter.

Actually, the fact that the plot is set in Brazil is of absolutely secondary significance, if not accidental. The real drama occurs within 
the family. It has universal character. The basic contribution of $\mathrm{La}$ voura arcaica is actually its being perhaps the first fictive Brazilian text showing Arab characters with great human density in deep psychological tension.

There is also another striking aspect: Raduan Nassar (a renowned stylist of the Portuguese language) has given the narrative an Arab voice by using metaphors of Oriental flavour and by inserting exemplary tales into the plot; tales that are typical for the sapient literature of the Middle East (like that of the hungry man to whom the sovereign offers empty plates in order to test his patience).

And Milton Hatoum - another renowned stylist of the Portuguese language - who ultimately destroys the stereotype of the Turk. Tale of a certain Orient is a novel about a Lebanese descendant who returns to his hometown in Brazil trying to retrieve his own past.

There is no linear plot in the book. The protagonist reconstructs and evokes memories of his past, visits places of his childhood and reunites with people. It is in this process that the Arab immigrant's profound drama emerges between the attempt to maintain his lost identity and the necessity of becoming integrated in a new universe.

The most distinctive character in the book (in my opinion) is that of the narrator's father; a Muslim married to a Christian, who prays locked up in his room, as if his relation to his own identity did not suit the context of Brazilian society.

This is the man who falls in love with a woman upon hearing of her beauty; who finds comfort in reading The Arabian Nights; who utters those typical concise Arabic sentences such as "You will find Paradise on earth on the back of a horse, in the pages of some books and between the breasts of a woman".

It is also interesting to mention that the protagonist's family is a typical one: they are traders like the majority of Arab immigrants. The difference is that they now have souls, they are really human, they live a personal tragedy.

After these two texts, the Turk disappeared. There were other novels such as The brothers, also by Hatoum (strangely enough, another drama containing certain incestuous tension, as if this symbolised the quest for cohesion in Arab families), Nur in the dark by Salim Miguel and even novels by non-descendants like Amrik and Desmundo (a word that might mean "anti-world") by Ana Miranda or Thousand 
years minus fifty by Angela Dutra de Menezes - all of them dealing with Arab characters and their children without the limiting stereotype.

When I was around thirty-five, I did not know yet that a certain set of poems would transform my life. After about fifteen years of studying Brazilian history, indigenous languages, African cultures (on which my first two works of fiction are based), a certain impetus made me seek my Arab identity again.

This was when I visited Lebanon, Syria and Jordan. And in a bookshop in al-Hamra street in Beirut, I bought a book called Literary history of the Arabs, by Reynold Nicholson. It was in this book that I heard about the Suspended Odes for the first time. It had a great impact on me. In fact, it was the biggest literary impact in my life. The few lines translated there, linked to the legends of the poets who created them, opened up a world undreamed of before.

Eroticism, generosity, eloquence, nobleness, dauntlessness, pride, loyalty, abdication, wisdom, the love of pleasure, disregard for riches - all this imbedded in the most beautiful poetic language - made me see in those heroes the model of man into which I projected my identity.

I decided to learn Arabic to be able to read those texts in the original language, at the same time buying all available translations of the Suspended Odes in English, French and Spanish, and devouring all the history books dealing with the pre-Islamic period, the Age of Ignorance.

Then I made a fundamental discovery: long before the birth of the Prophet, different Bedouin tribes who created the monuments of preIslamic poetry had converted to Christianity. The oldest Arabic inscription was engraved in a Christian church; there were Arabs among the bishops who debated on the famous Byzantine questions, among the first martyrs of Christianity, not to forget the Christians of Najran; even after the Muslim conquest a Bedouin and Christian poet had recited in front of the caliph upholding a crucifix; characters of fundamental significance to the Arab culture had their origin among orthodox Christians, such as Abu Tammam and Ibn al-Rumi; and even John Damascene, the last prominent Father of the Church, was originally called Mansur and was a grandchild of the Bedouin sheikh who negotiated the surrender of Damascus with the Muslims. 
To me this represented the end of the Phoenician theory that had irritated me so much. Now I knew that there were Bedouin ancestors among the orthodox Christian Arabs. The common identity of all Arabs was the unity of language, the ethical and aesthetic heritage of pre-Islamic poetry, differences in religion being irrelevant.

Enthusiastic about my new self, I dared something bigger: I started translating the Suspended Odes. Simultaneously, I began my third work of fiction, its protagonist being a Bedouin poet in the Age of Ignorance.

But I don't want to talk about my books. It was the experience of translation that was really fundamental. I lived in the Age of Ignorance during five years of recreating pre-Islamic poetry in Portuguese. Each verse, each image assumed new, superior beauty when understood in the original language. And it was only when I had finished translating that I realized what was happening to me there, in that moment, that I had actually become an Arab. It was not a question of religion or ancestry.

I remembered an antique ritual of the Tupi Indians (among which I also have ancestors) in which they adopted a name for each enemy they devoured. As if a new personality emerged from the absorption of another.

I was an Arab because I had learned Arabic and because I had emotionally relived the pre-Islamic poets' course in the desert. It seemed secondary that I had accidentally discovered an obscure history about a Muslim-born great-grandfather of mine, unknown to the family.

This was not important any more. I had become an Arab by adding the Bedouin poetical heritage to my aesthetic sensitivity. I no longer needed mirrors. 
Roland Spiller

\section{Dangerous Liaisons: Transatlantic Multilingualism in Latin American and Maghreb Literature. With Examples from Elias Canetti, Jorge Luis Borges, Rubén Darío, Assia Djebar ${ }^{1}$}

\section{Language and memory}

Meine früheste Erinnerung ist in Rot getaucht. Auf dem Arm eines Mädchens komme ich zur Tür heraus, der Boden vor mir ist rot, und zur Linken geht eine Treppe hinunter, die ebenso rot ist. Gegenüber von uns, in selber Höhe, öffnet sich eine Türe und ein lächelnder Mann tritt heraus, der freundlich auf mich zugeht. Er tritt ganz nahe an mich heran, bleibt stehen und sagt zu mir: “Zeig mir die Zunge!” Ich strecke die Zunge heraus, er greift in seine Tasche, zieht ein Taschenmesser hervor, öffnet es und führt die Klinge ganz nahe an meine Zunge heran. Er sagt: "Jetzt schneiden wir ihm die Zunge ab.” Ich wage es nicht, die Zunge zurückzuziehen, er kommt immer näher, gleich wird er sie mit der Klinge berühren. Im letzten Augenblick zieht er das Messer zurück, sagt: "Heute noch nicht, morgen.” Er klappt das Messer wieder zu und steckt es in seine Tasche (Canetti ${ }^{3}$ 1977: 9).

Elias Canetti's autobiography begins with this scene. With this memory, the title Die gerettete Zunge ("the saved tongue") takes on a first, wild, threatening, even eerie meaning. The laughing man is the lover of the Bulgarian nanny who looked after the two-year-old Canetti. The scene is repeated, sometimes several times a day. The threat was evidently effective, since Canetti did not dare relate the story until ten years later. Its position at the beginning of the autobiography shows that it takes on a more expansive, symbolic significances for the author, a Jew growing up on the lower Danube in Bulgarian Rousse (1905-1911). Canetti's early childhood was coloured by his multicultural environment - the Bulgarian of the nanny, meetings with Turks, Greeks, Albanians, Armenians, Russians and Rumanians that were everyday occurrences. After his childhood in Bulgaria, he spent his adolescence in England (Manchester 1911-1913), Austria (Vienna

1 Translation by Jim Phetterplace. 
1913-1916), and Switzerland (Zurich 1916-1921). As an adult, he chose to use the German language. The author Canetti also understood "the saved tongue" as "the saved language" and therefore the salvation of the language. In the Romance languages, this connection is even clearer, where the French "langue" and Spanish "lengua" mean both tongue and language. The coincidence also appears in the Turkish "dili", as Ottmar Ette impressively explains using the example of Sevgi Özdamar's programmatic title "Mutterzunge" ("mother tongue"). ${ }^{2}$ A second motif connected with and transmitted through language comes out in this beginning. The first chapter heading is "My earliest memory". The language of Canetti's earliest memories was Sephardic, the language of the exiled Jews, the Sephardim, though his parents communicated in German. German is neither his native language nor is it connected with the fatherland. As a biographical element, it represents an experience of breaking away, of varieties and dialects; Vienna and Zurich sound different. For Canetti, though his choice to use German granted him identity, it was not the same as selecting a national language. German is neither a native nor a foreign language, nor even simply the home of the author among languages; rather, it is found somewhere in between.

In the following text, I refer to two functions that determine this ambiguous area more clearly: the mnemonic and the emotive or affective. For the author Canetti, the threatening element of the language signifies rescue. As far as the emotive aspect is concerned, German for him is the language of love. After the early death of his father, he attempts to take the man's place by using German with his mother in everyday speech.

As a child of the upper class, Canetti is an exception, at least socially; his successful integration of biographical multilingualism and its literary preservation are hardly the rule among the children of Latin American immigrants in the US or those of the Maghreb in the suburbs of France. It is rare to even find an evenly balanced bilingualism; after all, who feels equally at home in the realms of the mundane, the feelings and thoughts of two cultures? Nevertheless, Canetti is a modern, multilingual author along the lines of George Steiner, who, like

2 Ette (2004), especially in the chapter: “Die gerettete Zunge” (Ette 2004: 232238). 
Max Aub, Samuel Beckett, Héctor Biancotti, Emile Cioran, Juan Goytisolo, Nancy Huston, Tahar Ben Jelloun, Milan Kundera, Eduardo Manet, and Jorge Semprún, more or less consciously chooses which language to write in. In the context of modern Europe, regularly adding countries and languages, multilingualism is also no longer exceptional. Increasing language contact - dependent on migration and globalisation - is a sign of the $20^{\text {th }}$ century. The integration and borders of the nation-states and national languages are thereby getting looser in literature. National literature is increasingly being written by people from other cultural spheres, for example German literature by people of Turkish ancestry, French literature by French-born Maghreb or African authors, English literature by Indians and Asians. Latin American literature is written to a large extent in the U.S., where entirely new cultural hybrids of U.S.-American literature are created. This trend also affects the corresponding language studies. It is questionable whether the future history of literature will manage without this category of national literature. One thing is certain: it will not be able to avoid considering the transnational patterns of behaviour coming about via decolonisation and migration.

These new, handed down patterns, which also determine transatlantic relations, fall in the space between literature and cultural studies. In Latin American studies, the close connection between the use of language and the cultural positioning of the speaker and the discourse is a central question. It has undergone great development since the conquest of 1492, took a new turn when independence was declared and has again gained new contours in the twentieth century, based on exile and the manifold migration. One phenomenon spanning over epochs and connected to the perceived relationship to language is the collective cultural memory. Language usage and the relationship to language always imply a certain position in the cultural memory of a society. This connection means that every literary text is integrated in a more comprehensive discursive situation and is therefore a social phenomenon; in the words of Bill Ashcroft: "The written text is a social situation". ${ }^{3}$

3 Ashcroft continues, “[...] meaning is a social accomplishment characterized by the participation of the writer and reader functions within the 'event' of a particular discourse. To take into account the necessary presence of these functions 
Canetti's example thus establishes an exciting link between multilingualism and cultural memory. However, a distinction must be made here. It is not enough to simply join in on the praise for multilingualism. Foreign language philologists in every field, comparativists, and even specialists in German studies consider monolingualism to be a flaw that should be corrected as soon as possible - via English language instruction for pre-schoolers at the latest. In the theory for language, literary and cultural studies, monolingualism is an unfashionable deficiency, manifesting itself through monologicality, that is, ideologically constructed simple-mindedness that serves the exercise of governmental and political power. For specialists in Romance language studies, the positive assessment of multilingualism is a downright intrinsic experience, sometimes biographically conditioned, but sometimes also plainly traceable to a love for other languages. In any case, the recognition of the relativity and the interconnectedness of national literatures is integral to Romance languages. It seems to simply be a logical consequence thereof to say goodbye to the idea of a hegemonic language. Mixed in with the pleasure felt by specialists in Latin American studies about the advance of Spanish in the U.S. is a bad conscience about Latin America's hegemony over its indigenous languages.

This supposedly unprecedented trend toward linguistic variety and difference must be relativized in the cultural history. In classical antiquity, the predominant attitude toward speakers of other languagesthe barbarians - was negative. Since the Middle Ages right up to the present, the relationship to the classical period has been per se multilingual. In his essay "Extraterritorial”, George Steiner makes reference to the fact that European literature from Petrarch to Hölderlin has been under pressure from more than one language (Steiner 1974: 18). He refers to the tradition dating back to the $18^{\text {th }}$ century of using Greek, Latin and French as the languages to be learned because they were considered "classical languages". Dante, Pico de la Mirandola, Erasmus von Rotterdam, Montaigne, Leibniz and Descartes were all at least bilingual. Steiner differentiates modern multilingualism from these epochs dependent upon the classical education of the European

and the situation in which the meaning occurs, the meaning may be called a 'situated accomplishment’” (Ashcroft 1995: 298-299). 
elite. He adds that classical multilingualism in the teaching of national literature in the Romance languages was accompanied by a strong tendency toward monolingualism. Multilingualism within a single text fell in the category of comedy or was even placed in the niche with macaronic verse. In particular, the modern 'high' literature tends toward monolingualism, an attitude that is changing drastically in the post-modern era.

The current trend to mixing languages could be contrasted with Paul Celan: "An Zweisprachigkeit in der Dichtung glaube ich nicht. [...] Dichtung das ist das schicksalhaft Einmalige der Sprache [...] also nicht das Zweimalige” (Celan 1983: 175). ${ }^{4}$ Celan's attitude to his German literary language was therefore anything but simple, being a multilingual translator who rubbed shoulders with the likes of Hans Magnus Enzensberger or Rainer Maria Rilke. His dictum gains weight from the fact that German is the language of the holocaust and nevertheless enables him to write poetry about it. The rejection of bilingualism in poetry reaches its deepest meaning in this form of remembering. It sets up a counterpoint to Adorno, who felt that after Auschwitz, writing poetry was vital for survival, in all languages, but especially in German. The collective could also "save their tongues" by talking about the injuries of the past.

However, accepting the truth of poetic uniqueness need not rule out the experience of multilingualism. Canetti's example helps clarify this seeming contradiction. Just like Celan's poetry, Canetti's autobiography touches the intersection of language and memory. As an anonymous, unconscious and collective artwork of a society, language is a memory for many voices. Writing is a constant work of remembering with the language and in the language, often with and in more than just one (Weinrich 1976: 294). An interdisciplinary effort is necessary to research the diverse connections between language and memory. My current aim is hopefully easier to reach: Using the example of literary multilingualism, I would like to present a single aspect that cuts across the various levels of this interconnectedness. I will concentrate on the emotive or affective function of language,

4 “I don't believe in bilingualism in poetry. [...] Poetry is the fateful uniqueness of language $[\ldots]$ and thus doesn't appear twice”. 
particularly important in the context of memory, and its representation in literature.

\section{Multilingualism, heteroglossia, and littérature mineure}

In his theory of the novel, Michail Bachtin uses the word heteroglossia to describe the heteroglot nature of natural language. He begins with the differentiation of centrifugal and centripetal forces in the development of European national languages. These forces also work within a language between the various dialects and sociolects. Heteroglossia affects the collective development of language as well as individual language usage. In novels, heteroglossia appears more strongly than its analogous term polyphony via the discursive diversity of narrators and figures that represent a situation of social antagonism. Bachtin's concept of dialogism was widely received in Latin America and Francophone regions. It has so far been mostly isolated, however, without consideration of the transatlantic exchange. This wide acceptance of the dialogic principle can be traced back to the societal need to recognise multiple voices and multilingualism. Bachtin's model of the novel describes the transsocietal communication metonymically. Only by including this external pragmatics can the current process of creating meaning between subject and society be understood. The search for social meaning has been concentrated on the borders and exceptions of culture for some time. The transatlantic relationships make up a large and multi-layered interspace. The heterogeneity is best observed in the newly forming zones of contact. Here, language is also a starting place for the process of negotiating new identities. Two examples: the increasing spreading of Spanish in the world is not only coming from Spain and Latin America, but also from the U.S.; conversely, in the Maghreb and Africa, French is being strongly held onto. In the regions of dissolving borders, the concepts of hybrids, like creolisation and métissage, serve to represent the multitude of voices and languages in the postcolonial world. Special attention is thus being paid to approaches like the "bi-langue" of the Moroccan Adelkebir Khatibi and Eduard Glissant's poetics "de la relation”, which strives for a unity of forces.

Before discussing the authors that serve as examples, I would like to return to the oft-mentioned "language as a home of the writer". The 
emotional content of this idea is evident. But how do writers imagine this home? Is it one home? Is it an identity of home and language? Writers look for a mother tongue, for a language that leads to the original naming of things experienced via the mother. Writing means recognising the loss of this supposedly original language (or tongue), ideally learned in the loving presence of the mother. Writing also means rising above an acceptance of this loss - making the unconscious conscious, which Freud observed as the universal language and whose linguistic structure was investigated by Lacan. Only by including this other language buried within oneself - though without declaring it an all-explaining unified language - does the emotive function open its entire width. The search for a home in language thus leads to the eerie realisation that language is not even one's own, that the linguistic sign and that which it signifies can be separated. The decentred subject can only approximate the lost original. The fact that this approximation, from the semiotic perspective, relates to the language itself and can take place quite lustfully - therefore being affective - was formulated by Roland Barthes with great clarity:

Le langage est une peau: je frotte mon langage contre l'autre. C'est comme si j'avais des mots en guise de doigts, ou des doigts au bout de mes mots. Mon langage tremble de désir. L'émoi vient d'un double contact: d'une part toute une activité de discours vient relever discrètement, indirectement, un signifié unique, qui est "je te désire", et le libère, l'alimente, le ramifie, le fait exploser (le langage jouit de se toucher luimême); d'autre part, j'enroule l'autre dans mes mots, je le caresse, je le frôle, j'entretiens ce frôlage, je me dépense à faire durer le commentaire auquel je soumets la relation (Barthes 1977: 87).

The desire experienced as lust expresses the open characters' relationship to language in two ways. On the one hand, there is the joy of language itself. On the other, it is a gloss, a commentary on the relationship being presented in the text as an amour. The commentary seems to be innocuous, however, particularly because it avoids any mention of the national language and instead appears to be translinguistic, because it includes all languages.

In contrast, George Steiner defines differently the "extraterritorial" type of writer, who is no longer enrooted in the national culture. Beckett and Nabokov are his representatives. Heinrich Heine, who mastered both French and German equally, serves as his forerunner; it was in relation to him that the paradox of homelessness in language 
first became clear (Steiner 1974: 19). Only someone who does not really feel at home in his language uses it as an instrument, Adorno said about Heine. Canetti is an example of this instrumentalisation; he developed intensive relationships to the various languages that he learned in the course of his life, yet presented them without passion. This is not the case with many Arabic, Francophone and Latin American writers, as we are about to see.

This spatially semanticised (or affectively charged) relationship to language also appears ex negativo in the image of nomads. In the manner of Deleuze and Guattari, as nomads in their own language, Franz Kafka represents the "deterritorialised" writer. The concept of a minority writing in the language of the majority, known as littérature mineure, is structured as a binary opposition. The nomads between minor and major literatures can be characterised as nomads within one and/or within several languages. As an example, I take Jorge Luis Borges. ${ }^{5}$ The Argentinean did not simply translate Virginia Woolfe's Orlando into Spanish, but also translated within his Spanish-speaking texts. This internal translation is so subtly manifested that one need not necessarily even sense it. It comes across more noticeably in the interplay with linguistic interference and in philosophical reflection over what language is and the Babylonian coexistence of various worldviews dependent on language. In his 1932 essay "El escritor argentino y la tradición", Borges anticipates the central questions of postmodernism and postcolonialism: What is it like to live in a peripheral culture? What does it mean to write in the language of the colonisers? His answer:

Creo que nuestra tradición es toda la cultura occidental. [...] Creo que los argentinos, los sudamericanos en general, [...] podemos manejar todos los temas europeos, manejarlos sin supersticiones, con una irreverencia que puede tener, y ya tiene, consecuencias afortunadas (Borges 1974: 273).

By Western culture he also means the corresponding languages. In advanced age, Borges wrote an "Ode an die deutsche Sprache" ("Ode to the German language") and began to learn Arabic in the last years of his life. In his work Borges gleefully translates the disrespectful ap-

5 For Steiner he is together with Nabokov and Beckett one of the three "most genial figures of contemporary prose" ("genialsten Gestalten der zeitgenössischen Prosaliteratur” [Steiner 1974: 35]). 
propriation of other cultures into reality. Therefore he became the model author for all of Latin America and was able to do the same for francophonie and postcolonial literature. Tahar Ben Jelloun, a Frenchspeaking writer from Morocco, paid homage to him in his novel L'enfant de sable.

Transatlantic Intertextuality 1: Borges, who appeared as a dream in a dream, symbolised the freedom of literature for those Moroccans who lived mostly in Paris. Borges' work lives on and in the tension between a heterogeneous national literature on the one hand and a European-orientated high culture on the other. His preferred narrative and aesthetic strategies were imitation and mixture; he preferred to situate himself linguistically in the interstice created by multilingualism. An example can be found in his reading of Dante.

Transatlantic Intertextuality 2: The opposite direction. In his essay "La Divina Comedia”, Borges describes how he reads Dante in a tram in Buenos Aires (Borges 1989: 208sq.). He uses a bilingual EnglishItalian edition and begins with the English translation. At a central point, however, where Dante reaches paradise, he reads the Italian original first and then the English translation. Borges, a polyglot and extraterritorial author par excellence, confesses in the same essay that he did not have a strong grasp of Italian; he "only" understood the older language. However one judges Borges' modesty in his representation of his multilingualism, the change from the translation to the original is significant, as it occurs because he is so emotionally moved. Dante, henceforth without the accompaniment of Virgil, meets Beatrice, the unreachable woman. At this key place Borges gives priority to the language of the original, of which he had a lesser command, to better enjoy the insuperable language of Dante. Admittedly, he immediately reads the English version afterwards. He then applies this use of two foreign languages within Argentinean Spanish creatively and parodistically in his "El Aleph", one of his best-known stories. In this case, the dangerous liaison is in the content, although one can also read the rejected love as an allegory for homelessness. ${ }^{6}$

6 Also see Adorno on Heine in Adorno (1974). 


\section{Latin America}

Starting with Borges, who like Canetti spent his formative years in Switzerland, further examples of internal nomadism in Latin American literature become evident. Other examples can be found in lyrical literature that go beyond Bachtin and contradict him in this point. ${ }^{7}$ One worth pointing out is Rubén Darío (1867-1916), the leading figure of modernism from Nicaragua, who spoke of French as his lover. He confesses his infidelity in a letter to his grandfather: "Abuelo, preciso es decíroslo: mi esposa es de mi tierra; mi querida, de París". 8 The concept of linguistic bigamy still enjoys great popularity today, especially among male authors, in particular from the Maghreb. Augusto Roa Bastos and Rubén Bareiro Sagüier from Paraguay can also be named; their novels written during their French exile are shaped by Guaraní's oral substratum. The Argentinean Juan Gelman also represents exile-related deterritorialisation. Though hardly known in this country, the poet belongs with Pérez Esquivel, winner of the Nobel Peace Prize, and the "Madres de la Plaza de Mayo" to the opponents of those who would forget their country. Exile, sadness, hope, love and language are existentially interlinked subjects of his work. In his nearly thirty volumes of poetry, he writes about tango and the holocaust, about the military dictatorship and the desaparecidos - the disappeared - which include his son and his daughter-in-law, who was pregnant at the time of their abduction. After moving to Rome, Paris, Madrid and Managua, he finally settled in Mexico. One of the great Latin American poets in exile, Gelman condensed the linguistic side of deterritorialisation by letting it implode. In the area of lexicon and the level of syntax, he created and deformed. Inventing verbs, changing gender and adjectives, in addition to the hyperbolic use of nearly untranslatable diminutives, show that his poetry gives expression to the battle of language with reality. For this reason, it is too simple to say that Gelman was true to his language. Jacques Derrida mentions in his book on Celan that the latter let his language migrate within German: Babel within a single language. ${ }^{9}$ The same can be said of Gel-

$7 \quad$ Also see Hopfe (1998).

8 Darío (1983), "Prólogo": "My wife comes from my country, my lover from Paris".

9 Derrida (1986: 125), in the footnote. 
man's Spanish. Through this internal Babel, both manage to express a possibly irreparable injury. The holocaust in one case and the Argentinean military dictatorship in the other are traumatising, deep wounds of the mind. Both poets demonstrate this by deforming the language. The injured mind is mostly represented by the scream, by stammering, floundering, absence and silence.

Gelman gives us an example of real translation in his bilingual volume Dibaxu, written in Sephardic and Spanish (Gelman 1999). While Darío develops his poetry, modernism, through his relationship to a French lover, Gelman, born in 1930 in Buenos Aires to Russian Jewish immigrants, finds his passion in the archaised Spanish of his ancestors. In contrast to Canetti, he never spoke this language, yet he writes Dibaxu bilingually.

Where can the transatlantic starting point (for the study of literature and culture) be found here? It is in the historical perspective. Darío managed to reverse the flow of dominant cultural influence up to that point; for the first time, an aesthetic movement shifted from the periphery toward the centre. With the figure of the French lover whose musicality seduced him, he founded Latin American modernism and overtook Spanish literature. Since recapturing Granada, the Spanish language ideal had been "casticismo", the purity of Castilian, which represented the central value of "hispanidad". At the end of the $20^{\text {th }}$ century, Gelman also instigated an event of language appropriation and transformation when he used the great tradition of Spanish poetry as his foundation. With the background of colonial history, both Darío and Gelman are considered impure poets who develop their poetry from their relationship to the language of the centre. Gelman compares the present situation of Latin America with the Spain of the $16^{\text {th }}$ century. He traces the clarity of the phrasing of Teresa de Avila and San Juan de la Cruz, his most significant role models, back to the fact that they were aware of the Spanish language that was in creation (Scheerer $(1987 ; 2002)$. In this way he indicates that the purity of Castilian is a myth. Through Darío and Gelman, the central idea of "hispanidad" experiences a cultural revaluation, extending far beyond the language, away from the colonial centre toward Latin America. One thing is certain: what changing their language or to nomadising within their own language means to writers affects the 
development of subjectivity as well as such major cultural currents as the transatlantic.

\section{Francophonie}

Though they do not cross the Atlantic, the dangerous liaisons of the French Maghreb do cross the Mediterranean. The French equivalent of the concept of hispanidad is francité. This term was not generally accepted, however, and was replaced by francophonie. The language situation here is more complex than that in the Spanish-speaking world, and a broader differentiation within the French language is therefore indispensable. The relationships between Creole and French in the Caribbean must be distinguished from those in Belgium or in Africa. An author in the Caribbean writing in French uses the social diglossia, though one can in turn differentiate this internal form of diglossia from the external form found in the Arabic-speaking world. What effect do these roughly outlined, typological differences have in the area of external pragmatics on the affective functions of a language?

One striking feature of Francophone literature is the overdetermination of the language consciousness. ${ }^{10}$ One example is the Moroccan sociologist and writer Abdelkebir Khatibi, who has studied the history of multilingualism and its functions extensively. In his novel Amour bilingue (1983), he employs a typical expression of higher language awareness by eroticising language contact. The male narrator, a kind of personification of language, joins the figure of bi-language in the ocean. This female protagonist is an imaginary mixture of mother and lover, the Arabic and the French. The features of the seductive "belle étrangère" are strongly present in her. Khatibi emphasises the affective function of passionate physicality, though without developing it into a cohesive whole. As a propagator of Barthes and Derrida in Maghreb, he emphasises the game of différance (with an "a") and the unending process of the displacement of sense. The representation of French as the "belle étrangère" is omnipresent in Maghreb, African and Caribbean literature. In the history of genre, its meaning appears particularly often in the autobiographical schematic. In the protago-

10 Lise Gauvin speaks of the "surconscience linguistique” (Gauvin 1996). 
nist's development, she fulfils a multi-tiered function of initiation in language, love and life. It is not rare for a transfer of the desire for the body of the teacher to the corpus of the language to occur. As early as in his La mémoire tatouée (1971), Khatibi described in his perfect mastery of the language his experience in French lessons as the school of seduction. In Le Polygone étoilé (1966), the Algerian Kateb Yacine emphasised the role of the beautiful French teacher who tears away his mother tongue, which resembles a second severing of the umbilical cord. Tahar Ben Jelloun also describes his relationship to French as something more passionate, with more clearly erotic features, than as something logical-rational. While French plays the role of the second woman, who seduces and wants to be seduced, Arabic appears as the wife. ${ }^{11}$ In Phantasia (1986), a novel by the Tunisian author Abdelwahab Meddeb, the Oedipal constellation underlying these dangerous liaisons is omitted in favour of the classical Arabic. He identifies the father with written High Arabic and the mother with the Arabian dialect. The paternal language for him is like the language of Virgil for Dante. The illiterate mothers, on the other hand, only understand Arabic with effort - and starting from the dialect:

[Arabic is] langue paternelle, comme l'est pour Dante la langue de Virgile, langue arabe que la génération des nourrices et des mères analphabètes entendent à peine, à travers les repères approchants de leurs dialectes (Meddeb 1986: 138).

Due to the connection of High Arabic with the Koran, the classical standard language is often a ground for conflict, as in Driss Chraïbi's novel, Le passé simple (1954), in which the young protagonist openly revolts against it. The affective function of language also appears clearly in a relationship filled with hate. The Algerian author Assia Djebar begins her novel L'Amour, la fantasia with the memory of her first day of school:

Fillette arabe allant pour la première fois à l'école, un matin d'automne, main dans la main du père. Celui-ci, un fez sur la tête, la silhouette haute et droite dans son costume européen, porte un cartable, il est instituteur à

11 “Ma seconde femme, je l’ai trouvée tout seul, ou presque. Elle m’était offerte, mais il fallait la séduire, jouer et intriguer avec elle pour la mériter et la garder” (Ben Jelloun 1995: 197). 
l'école française. Fillette arabe dans un village du Sahel algérien (Djebar 1995: 11).

The young girl holding her father's hand, being led to French, does not fit the male model mentioned thus far, but the fundamental coordinates remain comparable. The first chapter summarises the life story of the protagonist, changed by this event. As the title of the book indicates, love plays a central role in the story. The experience of love in the French language is ambivalent, however; it signifies a separation from the mother tongue. French, the language of distance and the outside world, suppresses the native language, the Arabian dialect, the intimate language of sentiment and nearness. It is a long path that begins on that first day of school. In the novel, it is doubled and deepened with Algerian history from colonisation to liberation. As Algeria is affected by colonisation, Assia Djebar feels herself and her body wrapped up and suppressed by French. The language of others, "la langue des autres”, envelops her body. The keywords are clear: mutilation, salvation and desire. The latter is not as strong as Khatibi's; nevertheless, French is the language of freedom, especially for the woman. Djebar's writing is a statement against the oppression of women. It is considerably more efficient for this purpose than the Arabian dialect, defined by male discourse as it is. The anonymous voices that make up the third part of the novel come mostly from women. The historian Djebar crosses the borders of history and fiction, high culture and folk culture, Arabic and French, the oral and written. In her "autobiographie au pluriel" she is a translator of spoken words, Arabic kalam, in French écriture. Differently from Canetti, the mutilation is actually executed, as with Atahualpa, the symbolic representative of Latin America. In the nations of Maghreb colonised by France, the children are taught, as the French, in French history and are thus robbed of their Arabian-Berber roots. Arabic is not on the curriculum; the historical memory of Algeria is mutilated. The novel begins with a quotation of Eugène Fromentin, a painter who accompanied the colonisation.

12 "A young girl going to school for the first time, a morning in autumn, hand in hand with her father. He, wearing a fez, silhouette tall and straight in a European suit, carries a school bag. He is a teacher at the French school. A young Arabian girl in a village in Algerian Sahel”. 
Il y eut un cri déchirant - je l'entends encore au moment où je t'écris -, puis des clameurs, puis un tumulte [...]. E. F. Une année dans le Sahel, 1852 (Djebar 1995: 11). ${ }^{13}$

At the end, this epigraph from Fromentin's report is repeated with some macabre details:

Au sortir de l'oasis que le massacre, six mois après, empuantit, Fromentin ramasse, dans la poussière, une main coupée d'Algérienne anonyme. Il la jette ensuite sur son chemin. Plus tard, je me saisis de cette main vivante, main de la mutilation et du souvenir et je tente de lui faire porter le "qalam" (Djebar 1995: 255). ${ }^{14}$

The important thing here is that the Arabic word "qalâm" means feather. By changing the severed hand into a writing quill, Djebar executes Canetti's salvation of the tongue. She grants the scream a new voice, a French one, but she does not just save her tongue by becoming a writer, but also that of the people because she translates the oral Arabic into written French. That sounds pathetic, but this pathos communicates a sobering realisation: when changing a scream into literature, as during the passage the one language into another, just then, when it happens in the eroticised code of love, there are limits and things that cannot be translated. The gap between the oral and the written as the central factor of diglossia connects the writing of Djebar with the literature of Black Africa, where authors like Amadou Hampaté Bâ are engaged in passing on the oral culture. ${ }^{15}$ This salvation of the tongue is also a main objective in Caribbean literature. Simone Schwartz-Bart, Maryse Condé, Edouard Glissant and Patrick Chamoiseau are cultural mediators, like Djebar, who want to transmit the knowledge, soul and life of the oral tradition.

In Francophone Maghreb, the salvation of the tongue in the language is often affectively charged and eroticised. Yet the question arises as to whether the admiration of French stressed by Senghor and Césaire, the founding fathers of francophonie, can be saved in the age

13 "There was a heartrending scream - I can hear it even as I write - then commotion, then a tumult [...]".

14 "Somewhere in the oasis, which had been plagued by the reek of the massacre six months earlier, he finds the hand of a woman in the dust. He picks it up and throws it away. Later I reach for this living hand, this mutilated hand of memory, and I try to let it carry the 'qualam'”.

15 Example texts: Koumen, 1961; Kaidara, 1969; L'étrange destin de Wangrin, 1973. 
of globalisation. In principle, the answer is yes. Nevertheless, and this is the commonality of the examples given, the old ideals are at stake in this salvation: pureté, clarté, rationalité, all the values that were once regulated by bon usage, which cared for the universality of the French language. The new generation, like Bernabé, Confiant and Chamoiseau in Eloge de la créolité (1989), sings the praises of métissage, that is, the impurity. Creole appears therein as a worldview suppressed by colonialism that should be preserved, not at the cost of French, but with it, with English, with Spanish. The poetry of créolisation that has emerged is found, as Glissant observed in his Poétique de la relation (1990), in the context of globalisation. With the Caribbean authors, we move further along the transatlantic spiral because their aesthetic is so close to the Latin American realismo mágico of García Márquez and the real maravilloso of Alejo Carpentier, without being directly attached. An aesthetic that can be designated as a comparativist aspect of heteroglossia at the interface of literature and culture.

In the course of globalisation, the bipolar concepts of centre and periphery, already undermined by Borges and deconstructed by Homi Bhabha, begin to totter. The one is penetrated by the other. If one attempts to place writers who are at home in several languages and cultures on the school curriculum, typologies that measure the relationship of centrifugal and centripetal forces are no longer sufficient. Concepts are needed that capture the relationship between language and its qualities. Research into the affective function is a starting point. Multilingualism has entered individual and cultural memory. This must be considered, especially when - as with Canetti and the former colonies - language signifies the memory of trauma and, at the same time, salvation.

In closing I would like to return to the question of the transatlantic connection between Francophone and Latin American studies. Is it not wishful thinking to want to bring together areas that are similar in general terms, yet in detail much too heterogeneous? Should these highly complex territories not be left conceptually and analytically separate? And is the search for a connection not simply another transfer of Eurocentric hermeneutics, with a demand for universality that is no longer sustainable in this postcolonial era? Does every understanding of the experience of others as different not come to a stop in order to cross into the process of projection of one's self? Facing these ques- 
tions, multilingualism proves to be a productive interface that touches issues of alterity and collective memory that are carried out in the conflicts of society. An example of multilingualism is the integration of literature in the overall, ever more problematic process of establishing meaning. Literature as a part of communication within all aspects of society - and this is the order of the day - can only be researched within a framework that accepts that language represents a living historical experience, and this experience flows into its various functions.

\section{Bibliography}

Adorno, Theodor W. (1974): "Die Wunde Heine”. In: Noten zur Literatur I. Gesammelte Schriften. Vol. 11, Frankfurt/Main: Suhrkamp, pp. 95-100.

Ashcroft, Bill (1995): “Constitutive Graphonomy”. In: Ashcroft, Bill/Griffiths, Garet/ Tiffin, Helen (eds.): The Post-Colonial Studies Reader. London/New York: Routledge, pp. 298-302.

Barthes, Roland (1977): Fragments d'un discours amoureux. Paris: Seuil.

Ben Jelloun, Tahar (1995): "Le polygame”. In: Le premier amour est toujours le dernier. Paris: Seuil, pp. 197-200.

Borges, Jorge Luis (1974): “El escritor argentino y la tradición”. In: Obras completas. Vol 1, Buenos Aires: Emecé, pp. 267-274.

- (1989) "La Divina Comedia”. In: Obras completas. Vol. 3, Barcelona: Emecé, pp. 207-220.

Canetti, Elias ( $\left.{ }^{3} 1977\right)$ : Die gerettete Zunge. Geschichte einer Jugend. München: Hanser.

Celan, Paul (1983): Der Meridian und andere Prosa. Frankfurt/Main: Suhrkamp.

Darío, Rubén (1983): Prosas profanas y otros poemas. Madrid: Castalia.

Derrida, Jacques (1986): Schibboleth pour Paul Celan. Paris: Galilée.

Djebar, Assia (1995): L'amour, la fantasia. Paris: Albin Michel.

Ette, Ottmar (2004): ÜberLebenswissen. Die Aufgabe der Philologie. Berlin: Kulturverlag Kadmos.

Gauvin, Lise (1996): "Glissements de langues et poétiques romanesques: Poulin, Ducharme, Chamoiseau”. In: Littérature 101, pp. 5-24.

Gelman, Juan (1999): Dibaxu, Debajo, Darunter. Dürnau: Verlag der Kooperative Dürnau.

Hopfe, Karin (1998): “Muttersprache, fremde Sprache. Zur Poetik Gabriela Mistrals”. In: Armbruster, Claudius/Hopfe, Karin (eds.): Horizont-Verschiebungen. Interkulturelles Verstehen und Heterogenität in der Romania. Tübingen: Narr, pp. 437-448.

Meddeb, Abdelwahab (1986): Phantasia. Paris: Sindbad. 
Scheerer, Thomas M. (1987): "Treffpunkt. Fast vergessenes Fragment eines Gesprächs im Jahre 1987”. In: zeit/kritik/bild/schrift 4, p. 19.

— (2002): "Der Skandal unaufhörlicher Schönheit. Über den argentinischen Lyriker Juan Gelman”. In: Hispanorama 95, pp. 55-62.

Steiner, George (1974): “Exterritorial”. In: Exterritorial. Schriften zur Literatur und Sprachrevolution. Frankfurt/Main: Suhrkamp, pp. 17-29.

Weinrich, Harald (1976): “Metaphora Memoriae”. In: Sprache in Texten. Stuttgart: Klett-Cotta, pp. 291-294. 


\section{Ottmar Ette \\ Chronicle of a Clash Foretold? ArabAmerican Dimensions and Transareal Relations in Gabriel García Márquez and Elias Khoury}

\section{ArabAmerican Greetings from a Camp in the Caribbean}

Dear Mother,

I'm writing to you from the seaside resort of Guantanamo Bay in Cuba. After winning first prize in the competition, I was whisked to this nice resort with all expenses paid. I did not have to spend a penny. I and Jamil [Al Banna] are in very good health. Everybody is very nice. The neighbours are very well behaved. The food is first class, plenty of sun and pebbles, no sand I'm afraid. Give my salaam to everybody and my special salaam to Wahab. I wish him the very best with his life, religion and business. I hope to see you soon if you want. Your son, Bisher.

p.s. Please renew my motorbike insurance policy (Brittain/Slovo 2004: 30). ${ }^{1}$

With these well-calculated words in a letter to his mother, Bisher al-Rawi summarizes his situation as a long-term prisoner in the U.S. American Camp Delta, Guantanamo Bay, near the Cuban city of Guantánamo. Are we dealing with fiction here, or with a nightmare that is entirely true? With both at once, of course. And this irresolvable entanglement is both intentional and theatrically composed. For the words are taken from the second act of a play written by the South African writer Gillian Slovo, now living in Great Britain, and the British journalist and academic Victoria Brittain, staged in 2004 by Nicolas Kent and Sacha Wares in London ${ }^{2}$ and New York. Sometimes with

1 I thank Peter Hulme (University of Essex) for alerting me to this play's existence.

2 The world premiere was held at the Tricycle Theatre in London on May 20, 2004. Five of the British Guantánamo prisoners mentioned or appearing in the play were not released until late February 2004; in preparation for the play, interviews and conversations with them were conducted in late March and early April 2004 (cf. Brittain/Slovo 2004: 3-4). 
subtlety, sometimes by means of striking agitprop, ${ }^{3}$ Guantanamo denounces the fate of the incarcerated, the torture-like treatment of those inhabitants of a univers concentrationnaire set up on the U.S. base in the Cuban Oriente, under conscious disregard for international legal standards, as part of the "war on terror" campaign of a government whose official policy is to promote human rights all over the world. The plot is allegedly taken from reality, or, in the words printed on the title page of the book edition: "taken from spoken evidence". The audience thus has every right to expect a veridical portrayal. Accordingly, the five British Guantánamo prisoners are joined by other real characters, including British Foreign Minister Jack Straw and U.S. Defense Secretary Donald Rumsfeld, in the form of original quotes. Fiction and documentation: The greetings from a camp in the Caribbean are directed to viewers and readers; they apply to us and affect us.

The words of the "U.K. resident" Bisher al-Rawi play ironically, even sarcastically with the predominant Western perception of the Caribbean as a vacation paradise under palm trees, where Western tourists lack nothing for their leisure. Indeed, this reality can be observed just a few kilometers away from Camp Delta; yet the radical break dividing the camp on the military base from the no less islandlike hotel facilities, where the very same nature is meant to serve an entirely different role and function, may remind us that Cuba is an island among islands and thus a highly complex island world. ${ }^{4}$ For the largest of the Antilles is an archipelago, and, what's more, a fractal world of islands, which face each other in such abrupt opposition that they might as well belong to different worlds.

And in fact: The Guantanamo Bay military base has its origins in the age of U.S. American troops' intervention in Cuba's colonial war of liberation against Spain, which, thanks to superior military technology, brought the U.S. a quick victory, dominion over broad sectors of the Caribbean, and expansion into the Latin American region. At the same time, Spain was banished once and for all from the American continent - as the colonial power that had set up concentration camps,

3 On the effect of the performance in New York in October 2004, cf. the theater review by Kaya J. Chwals (2005).

4 On this, cf. Ette (2001a). 
"campos de concentraciones", against its enemies for the first time in history, during the war unleashed by José Martí in 1895. The location for Camp Delta is well chosen indeed.

Hence concentration camps are not completely foreign to Cuba's history; however, until Camp Delta was established by the U.S. military, they had been used only against residents of the island itself. Nothing apart from their shared localization on Cuba seems to connect the anti-terror camp with those resorts the camp inmate writes his family about. And yet both of these self-contained island worlds, situated within a Cuba disintegrated into many insular structures, participate in a common development of which Bisher al-Rawi makes us profoundly aware: They are part of a globalization process that began on these very islands, the Antilles, with the so-called 'discovery' by Christopher Columbus, alias Cristóbal Colón, and transformed the Caribbean into a zone of highly condensed globalization. For the four phases of accelerated globalization experience thus far have left particularly deep traces in Cuban history and geography; the developments at the end of the fifteenth and the first half of the sixteenth century, in the second half of the eighteenth century, in the last third of the nineteenth century, and in the final third of the twentieth and the start of the twenty-first century were felt more intensively in this region of the world than in any other region on earth. Evidence of this includes not only the existence of the military base and the initially U.S.-dominated tourism industry at the turn of the twentieth century, but also the installations and facilities for supposed terrorists and traveling tourists at the turn of the twenty-first century.

Tourists, like terrorists, reach Cuba by airplane - and this, too, constitutes one of the parallels cited at the outset - that very means of transport which, alongside the Internet in the networked age, dominates the transatlantic movement of people. In the age of the still extant U.S. economic embargo against Cuba, which makes it difficult for U.S. citizens to visit the island, it is a paradox that Guantanamo Bay is the preferred destination for transport airplanes of the United States to unload on the Caribbean island their freight of terrorists, or those who are held to be terrorists. Of course, in contrast to the tourists' charter flights, the military transporters of the United States take off from

5 On this, cf. Agamben (2002: 175). 
Afghanistan or Iraq, thus linking them to the transatlantic migrations, primarily in the third phase of accelerated globalization in the final third of the nineteenth and at the beginning of the twentieth century, which led many Arab migrants first to the Caribbean and from there on to other parts of the American continent. Although Bisher al-Rawi may be unaware of this: His lines to his anxious family, constantly threatened by censorship, inscribe themselves in a history of ArabAmerican relations and, moreover, in a history of Arab-American writing, that has always been a "writing between worlds" in more than one sense.

The friction in these lines by the Muslim camp inmate of Camp Delta, oscillating between nightmare and fiction, consists in the very fact that they evoke the memory of this complex history of voluntary and compulsory migrations and transatlantic transfers in a condensed and dramatic form. For the long period of forgotten history of the ArabAmericas is just as multifaceted as it is fascinating. Literature, in particular, holds in store for us the life knowledge and survival knowledge which arises over its course, in the space where two heterogeneous cultural areas overlap.

\section{On the Way to an ArabAmerican Library}

It is certainly no coincidence that at this very point in time - in the context of the thesis of the "clash of civilizations", so effectively mediatized after its initial formulation by Samuel P. Huntington in the mid-1990s (Huntington 1996), and the "war on terror" propagated by the administration of George W. Bush as a counterstrike to September 11, 2001 - a number of Latin American and Arab governments also commemorated these multifarious historical and present connections between their countries. On May 10 and 11, 2005, representatives of the South American and Arab states met at the invitation of the Brazilian president in Brazil's capital, where they formulated the shared goal of "strengthening biregional relations, expanding cooperation and establishing an association to promote development, justice and international peace" in a joint "Declaration of Brasilia". The

6 Cumbre América del Sur - Países Arabes: Declaración de Brasilia (1, "Preamble”); quoted as it appears on the website of the Brazilian foreign ministry 
specified goal was thus to draft a true "reorganization of world politics in the twenty-first century" under the flag of multilateralism, designed as an alternative to the "self-fulfilling prophecy" of the "clash of cultures". The accord of this first summit meeting between the countries of Latin America and 22 member states of the Arab League, clearly directed against any and every form of unilateralism, dealt with issues as varied as the founding of a Palestinian state alongside Israel in the borders of 1967, the Iraq war and the U.S. sanctions against Syria, and even brought up the issues of the Falkland Islands (Malvinas), the propagation of atomic weapons and the containment of the drug trade in the final declaration of the summit, to which representatives of the United States were not admitted even as observers.

The heads of government also paid special attention to cooperation in the area of culture, recognizing from the very outset the "positive role of South American citizens of Arab origin in the advancement of biregional relations" (Declaración de Brasilia. Paragraph 3.1). This formulation throws a new light on an old story: the history of Arab immigration, which for a long period was hardly reflected upon publicly, and of peaceful coexistence with Arab immigrants in the whole spectrum of Latin American countries. This was at least an attempt to bring a dynamic, transareal dimension into Arab-Latin American relations beyond the bilateral, state-sponsored level, insofar as it emphatically drew attention to the importance of a group in the population that connects both areas historically and culturally.

In addition to the agreement on mutual cultural dialog and exchange, and the creation of research institutions and programs designed to foster biregional cooperation, what stands out is the joint declaration of intent to create, with the help of specialists, an "ArabSouth American Library", and for each region to provide for the translation of works considered to be important by the other's culture (Declaración de Brasilia. Paragraph 3.5). ${ }^{7}$ The result was to emphasize, on the highest political level, the shared history of Arab and South American or - formulated more appropriately - Latin American countries, hastened by processes of migration, and further to accentuate the

<http://www2.mre.gov.br/aspa/Decl/espanol.doc>. I thank Günther Maihold for pointing this out to me.

7 According to paragraph 3.7, a seminar of specialists for the founding of such a library in Aleppo, Syria, is to be conducted in October 2005. 
necessity of developing forward-looking joint cultural projects like an Arab-Latin American library. In this manner, the paths of the migrants open up a new politics of advancement, and an awareness of paths of knowledge that were paved long ago, but as yet seldom reflected upon.

Not to underestimate other aspects of the "Declaration of Brasilia" - such as the planned economic, financial and social cooperation, and also collaboration on technology and information and in all areas of sustainable economics - the cultural sphere in particular appears to be experiencing a new biregional, or - in a more comprehensive sense transareal expansion of horizons. This could advance relations between the two regions of the world considerably in the South-South context, independent of Europe and the United States.

Certainly, the summit meeting was overshadowed by numerous frictions among the countries of Latin America as well as the absence of many Arab heads of state; of course, the economic and trade policy goals linked with this summit, especially by the Brazilian government, were not directly realized; and the founding of a joint committee of Mercosur and the Gulf Cooperation Council with the goal of a freetrade agreement may be regarded with as much skepticism as many other ambitious declarations of the summit. ${ }^{8}$ Further, one can take the stance that the political positions in the final declaration were more clearly in the interest of the Arab countries, as its criticism of U.S. policy in the Near and Middle East could not be overheard. However, categorizing the summit as a mere "Arab Summit" (Hofmeister 2005: 6) certainly does not do justice to the long-term importance of this meeting for the area of politics and, above all, for the cultural sphere not to mention the fact that the Latin American countries, under the stern gaze of the United States, demonstratively increased their foreign policy latitude.

For this was the first time that a declaration was formulated not on a binational level, but on a level affecting the whole of both areas of the Latin American and Arab countries, which emphasizes the necessity of advancing "cultural identities" and mutual dialog about cultural aspects of coexistence (Declaración de Brasilia. Paragraph 3.3). Even

8 Cf. the critical comments from the Konrad Adenauer Foundation by Hofmeister (2005). 
the aspired cooperation in the area of audiovisual and other communications media, as well as in the area of education, including the university sector, points out the effort to strengthen South-South relations in the ArabAmerican field of conflict, as it attributes an important and meaningful function to culture, or at least to the "diversity of each group’s cultural heritage” (Declaración de Brasilia. Paragraph 3.11).

But at the same time this should open up new paths of knowledge that - as we saw - raise awareness of the inter- and transcultural experience of Latin Americans of Arab extraction, a group that may have fallen into oblivion in the public discourse, but much less so in the area of literature and their specific life knowledge. Perhaps the project of a "Latin American-Arab Library" may be understood primarily as a biregional attempt to assemble the literatures of Latin America and the Arab world and their respective main representatives in the form of a canon of reading, as this would harbor the chance to open up a dimension that is not only biregional and intercultural, but also transareal and transcultural, dedicating its main focus to the movements connecting and networking the two areas with each other. Instead of, or in addition to, a static addition of 'great works' that appear significant for the respective cultural spaces, a dynamic notion of cultural mobility would appear, which could interlace the two cultural spaces more closely. The following remarks are dedicated to such a transareal (and not only biregional) and at the same time transcultural (and not just intercultural/translating) ArabAmerican Library.

\section{The Pattern of Arrival and Motion in an ArabAmerican Turnstile}

The novel La caída de los puntos cardinales by the Colombian author Luis Fayad would doubtlessly occupy an important space in such a transareal ArabAmerican Library. Toward the end of the first part of this novel published in the year 2000, the arrival of a group of Arab immigrants on the Caribbean coast of Columbia at the beginning of the twentieth century unfolds before the eyes of the readers:

Yanira llevaba una blusa blanca con bordados cerrada en el cuello y una falda larga que no se distinguía de las faldas de las mujeres que vieron luego en el lugar. Se distinguía por el bolso de tela tramado con hilos de colores que le servía de equipaje de mano. Dahmar iba con una camisa blanca de seda y un pantalón de tela fina de corte europeo adquiridos a su 
paso por Marsella. Sus paisanos quisieron bajar juntos por la pasarela y de todas maneras al final, cuando tocaron tierra, los hicieron formarse en grupo. El agente de aduanas anunció con tono alegre que los extranjeros debían apartarse unos pasos, entre ellos los turcos. Dahmar les tradujo la orden a sus paisanos y el más joven, de unos dieciocho años, se sintió maltratado.

- ¿Turcos? -se preguntó y se dirigió a Dahmar-. Dile quiénes somos.

-Aquí somos turcos - dijo Dahmar.

Por las cartas que llegaban al Líbano sabían que en este lado les daban ese nombre por cargar el pasaporte de las autoridades turcas.

-Pensar que mi padre estuvo preso por culpa de los turcos -dijo el que se sentía maltratado-, y ahora me llaman turco (Fayad 2000: 84).

The travel literary place of arrival ${ }^{9}$ always represents a semantically highly exponentiated literary passage, in the course of which the layers of meaning become entangled with each other and central patterns of meaning of a text are revealed. The scenery of arrival unfurled with such literary mastery by Luis Fayad is the setting for a game of similarities and differences that begins relating the group of immigrants from Lebanon to the local population even before the former disembark. In this game of distinction, in which Dahmar, with his European clothes purchased en route in Marseille, occupies an intermediary position between the Arab and the Latin American world, an important role is accorded to clothing. The clothing worn in this passage is important not only because it marks identity or bears symbolic importance, but also because trade with textiles will represent a significant economic pillar for many of the immigrants as the novel progresses - just as it does in the social reality of Columbia.

Dahmar again takes on an intermediary role, which involves translating in many senses, when he translates for the immigrants who cannot yet speak Spanish the order that all "foreigners", including the "Turks", should always remain separated from the other passengers. This interlingual activity at the very moment the passage from the Old World to the New is completed is illuminating insofar as the Lebanese immigrants experience the Colombian authorities assigning them not only a new nomenclature, but also a new identity: For the Colombians they have become Turks, although their families suffered under Turkish rule in the Ottoman Empire. Thus their flight from the Turks in the Old World paradoxically results in their being identified as Turks in

9 On the concept of travel literary place cf. Ette (2001b: 62-80). 
the New World. Yet the travelers were prepared for this, as the letters from other Lebanese emigrants had already reported in detail about the Quiproquo, this game of mistaking political and cultural identities. So the passage to a new world is connected with the attribution of a "foreign" identity, which is perceived by some as an immediate violation: Setting foot in the country of immigration quasi transforms the opponents of Turks into Turks themselves overnight. ${ }^{10}$ Emigration from the Arab to the Latin American world - and with it a progression of de-territorialization and re-territorialization - changes attributions of identities in a fundamental manner, thanks to a radical recontextualization that recodes linguistic and conceptual, political and cultural positions, setting them in motion.

The refugees, who - as we will soon see - have just fled Lebanon, a country plagued by civil wars, know that civil war is also menacing Colombia, yet upon their arrival they encounter no indications of acts of war of any kind: The conflicts, an officer explains to them, were taking place far away in the country's interior (Fayad 2000: 84sq.). So upon their very arrival all of those violent conflicts are heralded in which some of the immigrants will later become ensnarled. Quite soon the young Hassana and others familiarize themselves with fruits and manufactures, but also with linguistic expressions and everyday characteristics of the Colombian Caribbean coast (Fayad 2000: 91). On their trip to nearby Barranquilla, the Arab immigrants discuss the trees and the many birds whose song wakes them up in the morning (Fayad 2000: 92): It is the discovery of the New World as a world new to them, with which they attempt to become familiar bit by bit.

Thus the gently contoured development points out how the Lebanese 'turcos', and these 'fake' Turks and their children, gradually become inhabitants of the country as ethnically Arab Colombians, who initially secure their survival, and ultimately, thanks to their hard work, the organization of their own life with all of its cares, in a country repeatedly convulsed by acts of violence. The Latin American country becomes a second home for all of them. Consequently, Yanira, whom we met as Dahmar's young wife in the arrival scene, says at the end of the novel:

10 The Scottish traveler Cunningham held this nomination of the Arab population at the Caribbean coast he visited to be cruel; on this, cf. García Usta (1997: 127). 
Yanira se había quedado pensativa. Recordaba que al nacer su primer hijo sintió que por fin tenía algo de aquí y ahora con Dahmar enterrado cerca de su casa ya no podía ser de otro lugar. Muhamed repuso que en ese último año había sentido lo mismo (Fayad 2000: 321).

In the triangle of her feelings and experiences between the birth of her first child, the death of her first husband and the imminent fulfillment of a second love, there is no other place where the woman who came from another place can live in her own house: In both senses of the word, Lebanon is suspended in Colombia. The experience of birth, death and love in her own house suspends not only the oppositions between the spaces, but also those between the times, as the lyricalsensual end of the novel shows in its disrobing:

Yanira deshizo una punta de la colcha y una de la manta y empezó a desvestirse. La iluminación de la lámpara continuó toda la noche. El silencio se regó tejido en el aire. No hubo nada que decirse, ni para llamarse por sus nombres, ni para celebrar el encuentro. Fluyó la sensación de que si nunca se adelantaron para estar en ese momento, tampoco llegaron tarde a él (Fayad 2000: 322).

Although it is not possible to go into all twists and turns of migratory origin at this point, two other aspects important for this line of questioning should be highlighted. For one, it is no coincidence that this migration from a country in the Arab world torn apart by civil war into a country in the American hemisphere torn apart by civil war leads across the Caribbean, which has been the hub and a major reloading point for centuries, not only for the slave trade, but for a multitude of large-scale migratory movements and displacements as well. The wave of migration from Arab countries that began in the second half of the nineteenth century and reached its peak at the turn of the twentieth century - especially from Syria, Palestine and Lebanon follows the old transatlantic paths, which channeled the always asymmetrical "exchange" between the continents of the Old World and the different regions of the "new" continent. The Colombian coast of the Caribbean is just one part of a complex circum Caribbean and hemispherical lattice of relationships, which places the most opposite areas of natural space, sociopolitics, economics and culture in relation to each other. Translocal and transregional, transnational and transareal relations are mediated in this fractal, vectorial space, which is intersected by discontinuities of all kinds and literally translated into other logics. Luis Fayad's novel illustrates this to us impressively by means 
of many examples. As already heralded in the novel's title, in Luis Fayad's work the cardinal points of orientation fall victim to these unsteady and yet powerful movements and then dissolve. The novel by the author born in Santa Fé de Bogotá in 1945, who has lived temporarily in Barcelona, Paris, Stockholm and Berlin since the 1970s, makes an initially delocalized and subsequently translocalized knowledge, based on an oscillation between the places of reference in the Old and the New World, into the pivot and hub of a literature that can be characterized as a "writing without a fixed abode". For even the "puntos cardinales" of this Colombian writer readjust over and again within a constantly shifting magnetic field.

On the other hand, a complex intertextual network is erected in $L a$ caída de los puntos cardinales, although this is of interest to us here only insofar as it regards the texts of another Colombian author, whom we may also associate with the Caribbean. Muhamed, the character in Fayad's novel mentioned above, had fought several years long as a soldier among the insurgents, who ultimately succumbed to the superior force of the government troops. Once again, marching past his (and our) eyes in rapid succession, come the events of that civil war, which was only the most recent in a long series of civil wars:

En la lucha salvó de la muerte a un compañero y fue salvado él mismo por otro, tuvo que huir de una plaza, se escondió y volvió al frente, presenció el momento en que iban a fusilar al coronel Aureliano Buendía y no lo fusilaron, estuvo presente en la toma de pueblos, cuidó prisioneros y fue centinela de confianza en los cuarteles. Al ser derrotado no se orientó en la fuga y fue a dar a la casa de Ibrahim (Fayad 2000: 136).

Not only for Colombian readers does the mention of the name Aureliano Buendía call to mind Gabriel García Márquez’ Cien años de soledad (1967), the masterpiece by the Colombian winner of the Nobel prize for literature, which is marked by the family history of Buendía, but at the same time cryptically pervaded by many allusions to Arab immigration in the Caribbean coastal area of Colombia. ${ }^{11}$ The Arab immigrants could not be lacking in this Latin American microcosm, as they indeed contributed decisively to the development of this part of Colombia and left their mark on its economic, social and cultural evolvement.

11 On this, cf. García Usta (1997). 
Yet the relationship to another novel by Luis Fayad's compatriot also obtrudes, whose protagonist hails from a family of Arab immigrants and in which - as in La caída de los puntos cardinales Aureliano Buendía is also mentioned only a single time: Crónica de una muerte anunciada. ${ }^{12}$ With this not only the intratextual relationship between the novels of García Márquez becomes evident, but also the intertextual relationship between Luis Fayad's ArabAmerican immigrant novel and Chronicle of a Death Foretold, published for the first time in 1981, a text that has long since advanced to become a classic of Latin American literature, and which for many reasons - as the following remarks intend to show - also deserves to be included in an ArabAmerican Library.

\section{Chronicle of a Clash of Cultures Foretold?}

Gabriel García Márquez’ familiarity with the ways of life and the life knowledge of the descendants of Arab immigrants on the Caribbean coast is beyond question. Even in his childhood and youth he kept company with many families of Arab extraction and later cultivated these contacts in his professional and his private life. So in view of both the historical development of Colombia and the personal life path of the writer, it is hardly a surprise that there are 'Arabs in Macondo', especially since García Márquez’ wife, Mercedes Barcha, is the daughter of an Egyptian engineer, who was brought to the country by General Rafael Reyes to execute certain projects. ${ }^{13}$ García Márquez thus occupied himself over and again with the characteristics of the immigrants, chiefly from the Near and Middle East, from Syria, Palestine and Lebanon, who also went to other regions of the Caribbean and Central America such as Cuba, Haiti, the Dominican Republic and Trinidad, but even Costa Rica and Honduras, and many of whom settled in Colombia, especially along the Rio Magdalena and the Carib-

12 This single direct reference to Aureliano Buendía is located in García Márquez (1981: 55); there the father of Bayardo San Román, General Petronio San Román, is introduced as the hero of the nineteenth-century civil wars, "una de las glorias mayores del régimen conservador por haber puesto en fuga al coronel Aureliano Buendía en el desastre de Tucurinca".

13 Cf. García Usta (1997: 137). References to relationships between the writer and the ethnically Arab families Mattar, Janne, Kusse and Cassij during his time in Sucre are also found here. 
bean coast - the main settings for the novels of García Márquez. The Arab immigrant groups living there today consequently constitute a component of the population that is just as significant as it was in the population of the narratives by Gabriel García Márquez.

The situation found there by the people from the Near and Middle East who arrived in the 1880s was that of a both economically and socially backward, peripheral part of the country, which forced upon them hard living conditions, but also offered them opportunities for social advancement. Without a doubt, the main economic support of the immigrant groups that came to the country in several waves until the mid-twentieth century was trade, such as that concentrated in the "Calle de los Turcos", the "Street of Turks" in García Márquez' Macondo. While García Márquez shifted the arrival of the first Arab migrants in Crónica de una muerte anunciada to the first years of the twentieth century (presumably for reasons having to do with the diegesis of the novel), the way he depicts the socio-economic and cultural embedment of the population groups of Arab extraction is closely oriented to the historical realities in Colombia. This country's stream of immigrants from Arab countries ran dry shortly after the middle of the last century, while continuing to increase toward the United States and Canada.

The circumstances surrounding the appearance of Chronicle of a Death Foretold have been widely discussed. In 1982, with this short novel consisting of five parts, Gabriel García Márquez effectively broke his years of silence as a writer. He had maintained this silence as a signal for the entire duration of the U.S.-supported dictatorship of Augusto Pinochet, who had come to power in Chile through a bloody coup on another September 11, that of the year 1973. The wellprepared international marketing strategy for the book, which involved collaboration by four different publishing houses so that the first print run totaled one and a half million copies worldwide, shone the spotlight on a specific 'Latin Americanness' in the realismo mágico style. For a long time, this ensured that the novel's reception concentrated on certain aspects: the central plot line of the murder in response to violated family honor, ${ }^{14}$ the bloodbath of a Latin American - Colombian - family tragedy semanticized as the New Testa-

14 Recently this topic was picked up again in Zimic (2001). 
ment, ${ }^{15}$ the importance of elements specific to the genre of criminal and detective novels, ${ }^{16}$ and the complex narrative structural arrangement of this text that contributes to the suspense it creates. ${ }^{17}$ In contrast, the levels of meaning of this Chronicle connected with the Arab American dimension, to be elaborated below, remain largely in the background.

The central strand, which García Márquez tackles by telling the story in medias res and developing it piece by piece through an elaborate sequence of prolepses and analepses, revolves around the fact that the extremely rich newcomer, Bayardo San Román, wants to take Angela Vicario as his bride, forces her to marry him, celebrates a boisterous wedding party to which the entire town is invited, but then gives the bride back to her family on the wedding night because she is no longer a virgin. On the morning of her "repudiation", the apostolically named brothers Pedro and Pablo cleanse this family disgrace, soon common knowledge in the town, with the blood of the man Angela Vicario names as the supposed perpetrator: Santiago Nasar. The fact that the ArabAmerican element - that is, the complex relations between the Arab and the American worlds - plays an important role in this novel, which, thanks to the bundling of its strands, cannot hide its tendency toward an novelistic portrayal of the 'unheard of event', and that this element transverses the entire text and bears significant determinative power, has received at best marginal and fairly incidental mention in the research to date. When acknowledged at all, casual mention of short references to the Arab extraction of some characters in the novel has been regarded as completely sufficient. The structure of this Chronicle of a Death Foretold as a puzzle seemed to be associated primarily with the topics mentioned above - which are certainly important as well.

And yet even the first sentence, by now certainly one of the most famous, not only in Latin American literature, contains several references to the Arab-American level of meaning incipit: "El día en que lo iban a matar, Santiago Nasar se levantó a las 5.30 de la mañana para esperar el buque en que llegaba el obispo” (García Márquez

15 Cf. recently, among others, Pelayo (2001).

16 Cf., among others, Pöppel (1999).

17 Here reference is made only to the detailed and illuminating narratological and intermedial analysis of the novel and its filming in Schlickers (1997: 280-373). 
1981: 9). First of all, the very name of the protagonist, whose murder is at the focus of the entire plot and time structure of the novel, refers to an Arab-American isotopy insofar as the two components of his name are of both Spanish, that is, Christian-Western, and Arab provenience. Of course, the spelling of the last name draws attention to the fact that the Arab name has been Hispanicized and adapted to the writing habits of Spanish-speaking countries.

At the same time, the wait for the anticipated arrival of the bishop, who, accompanied by his 'Spaniards,' will bless the harbor and the city from the river steamer, but contrary to the hopes of the city's residents, will not actually set foot there, refers to the accentuatedly Catholic religious affiliation of the protagonist, who presumably comes from a Christian Arab family. This, moreover, corresponds to the especially high share of Christian migrants from the Near and Middle East, while at the same time indicating the pressure the local population placed on this group to adapt, which certainly played a role in this ostensive profession of Catholic faith. Luis Fayad had by no means forgotten these components in his successful fashioning of the arrival scene; indeed he has his border official, who knows the answers expected from the Arab immigrants, ask sullenly, “¿Qué religión tienen ustedes? Ya sé que me van a decir que son cristianos aunque no sea verdad" (Fayad 2000: 86). The religious suspicion of the receiving population with regard to the new arrivals of Arab, that is, 'Turkish' extraction, forces them into an ostensively Catholic practice of faith.

Interspersed in the individual strands of the story are permanent elements, which blend into the diegesis of this seemingly simple novel the history of immigration - of not only the family, but of Arab groups of migrants in general. At the same time, the publicly proclaimed murder, which the Vicario brothers commit, killing Santiago Nasar because their sister Angela Vicario makes him responsible for her lost virginity, tears ethno-cultural lines of conflict back open, lines which had often been recognizable in the everyday life of the novel's characters only upon precise, 'investigative' reading.

An important indication of these concealed, if by no means invisible, zones of conflict and group memberships is offered by the spontaneous reactions to the bloody deed. While Pedro and Pablo Vicario had continued to celebrate lightheartedly and fraternally even after the wedding party was over, not only with the narrator, but also with San- 
tiago Nasar, when pursued by a "grupo de árabes enardecidos" after murdering Nasar (García Márquez 1981: 79) they flee as quickly as possible into the protection of the church. Still, in the almost lovingly prepared jail of their hometown, in which at first they feel "a salvo de los árabes” (García Márquez 1981: 127), Pablo Vicario fears that his constantly urinating brother Pedro could have been poisoned by the Turks' evil tricks ("vainas de los turcos" [García Márquez 1981: 129]). Fearing attacks, Coronel Aponte, the town's mayor, harbors the brothers in his own home until the examining magistrate transfers them to the prison in neighboring Riohacha (García Márquez 1981: 129). The widespread fear of violent retaliations by the 'Turks' is an unmistakable indication of existing multicultural faults and fractures.

The homodiegetic narrator, instilled with the knowledge of local life, knows just as well as the town mayor that the twin brothers' fear (terror) of attacks corresponds to the perception on the street, that is, the general population, which continues to fear "una represalia de los árabes” (García Márquez 1981: 130). Yet the townspeople are less concerned about poison than the possibility that the Arabs could pour gasoline over the prison and prisoners at night and set them on fire (García Márquez 1981: 130). What indications are there for this? Do the contours of a 'clash of cultures' become apparent here? The narrator attempts to pacify and calm his readership:

Los árabes constituían una comunidad de inmigrantes pacíficos que se establecieron a principios del siglo en los pueblos del Caribe, aun en los más remotos y pobres, y allí se quedaron vendiendo trapos de colores y baratijas de feria. Eran unidos, laboriosos y católicos. Se casaban entre ellos, importaban su trigo, criaban corderos en los patios y cultivaban el orégano y la berenjena, y su única pasión tormentosa eran los juegos de barajas. Los mayores siguieron hablando el árabe rural que trajeron de su tierra, y lo conservaron intacto en familia hasta la segunda generación, pero los de la tercera, con la excepción de Santiago Nasar, les oían a sus padres en árabe y les contestaban en castellano. De modo que no era concebible que fueran a alterar de pronto su espíritu pastoral para vengar una muerte cuyos culpables podíamos ser todos (García Márquez 1981: 130sq.).

The history of Arab immigration in the Caribbean region, outlined here in a few lines, projects the image of a minority closely united through linguistic, onomastic, cultural, economic and matrimonial ties, whose cultural orientation and socio-economic integration, in the eyes of the narrator, do not make it seem likely that it, as a group, 
could take revenge for the murder of one of its own, for whom - as the narrator admits here - in a certain sense not only the Vicario brothers, but ultimately all inhabitants of the town are responsible or at least share responsibility. Even the suspicious fears of the seasoned Coronel Aponte, that a bloody "culture war" could be about to erupt in his little town, are dispersed once and for all when he visits each of the Arab families in town and is able to establish that they are wearing mourning, but not forging any kind of plans for revenge (García Márquez 1981: 131). What's more: Even the ones who had pursued the murderers immediately after the bloody deed, amidst a population that had witnessed the murder without doing anything to prevent it, dispute that they had ever intended to take the murderers' lives. The hundredyear-old Suseme Abdala even sends the Vicario brothers a special medicinal tea that relieves Pedro Vicario's condition. The Arab, that is, the ArabAmerican community, takes pains to send out signs of reconciliation and to return to peaceful coexistence, as if nothing had ever disturbed this peace.

Thus the danger of a "clash of civilizations" feared by the residents of non-Arab extraction is dispelled in García Márquez’ Caribbean microcosm, at least on the side of the turcos. In the events surrounding the murder of Santiago Nasar, 'the Arabs' or 'the Turks' may well be discerned as a potentially dangerous group and kept under surveillance by the executive power, but they obviously present no danger to peaceful coexistence. Of course, the Arab immigrants are only one part of the heterogeneous population: that Crónica de una muerte anunciada also contains references to Spaniards, Catalonians, freebooters, other groups of European immigrants, and, above all, former slaves who had been transported from Africa, is virtually a matter of course. From the newlyweds' house, just a few hours before his death, Santiago Nasar shows the narrator and the Vicario brothers a flickering light near the Cartagena de Indias, marking the place in the Caribbean Sea where a slave ship from Senegal sank long ago, and where the unredeemed souls of the slaves appear to this day (García Márquez 1981: 108). The image of the Caribbean as a migratory hub is omnipresent.

The ethno-cultural heterogeneity of the population on the Caribbean coast is an element of the Caribbean universe. At the same time, however, in this profound novel it has become clear that the Arab im- 
migrant families, even in the third generation, are still recognizable as an independent group and are perceived as such 'from outside'. Thus it is worth looking more closely at the literary representation of these Colombians of Arab extraction in the novel. Should Santiago Nasar's belonging to this group - as most research so far has assumed - really be of only marginal importance?

\section{Lines of Conflict in the ArabAmerican Context: Clash of Lineage and Clash of Cultures?}

Of course, within an immigrant society - and there is no mistaking that Colombia was an immigrant society in the second half of the nineteenth and the first half of the twentieth century - these Arab immigrants constitute only one migrant group, albeit one that is relatively pronounced in the Caribbean. In particular, their marriage policy constitutes an unmistakably multicultural pattern of behavior, which can be interpreted as the coexistence of a parallel social sphere, insofar as it reaffirms a 'coexistence' of cultures, or of ethno-cultural groups, thereby anchoring its own future in an ArabAmerican genealogy.

Santiago Nasar, too, follows the rules of the game observed within this group for the most part. Certainly, he always keeps an eye out for sexual adventures with other women - just like the ones his father had with girls of inferior social status like Victoria Guzmán -, after having been initiated into the arts of love by the seductive owner of the brothel in his youth. Yet for his own wedding only a girl of Arab extraction comes into question. Therefore he respects unconditionally the contract his parents made years ago with the parents of his future - and by no means beloved - wife Flora Miguel (García Márquez 1981: 178).

The predominant patriarchal features, unchallenged within the Arab-American community, are unmistakable. They regulate even, and not least, the way men behave toward each other. Escapades by the male members of the community are tolerated as a matter of course. Nahir Miguel, the father of the bride and uncontested ruler in his home, is the first to grasp the danger threatening his future son-inlaw, and makes him an offer in Arabic, to either hide him in his house or to arm him with his rifle so that he is not defenseless at the mercy 
of the Vicario brothers. In complete contrast to his daughter, at no point does the man with an imperious manner, who wraps himself in his "chilaba de beduino" in his home, but never on the street (García Márquez 1981: 181), call into question the contracted marriage of the ethnically Arab couple. The patriarchal dominance constitutes a largely stable, secure and insular sphere, which defines the rules of marriage to which the women must subjugate themselves - even though it leaves Flora Miguel, desperate after Santiago Nasar's murder, to throw herself at a "teniente de fronteras", who later has her working for him as a prostitute (García Márquez 1981: 156).

Within his family, Santiago's father Ibrahim Nasar also embodies the patriarchal type. As the narrator tells us, he had come to the town with the last Arabs at the end of the civil war (García Márquez 1981: 21) and rebuilt the warehouse on the main square, which had become useless because large ships could no longer put in at the inland river harbor, choked with sand. He was able to use the fundamental economic changes intimated here to his advantage, erecting a cattle hacienda and ascending to the town's ruling class. Within just a few years his societal integration appears successful: The Nasars are respected both within the Arab-American community and in the structure of the town as a whole, and enjoy power and influence. Santiago himself is indisputably considered the best match in town - besides Bayardo San Román, who arrived for unknown reasons a few months before his wedding with Angela Vicario. Does this not amount to a perfect story of social integration?

To his son, with whom he is very close, Ibrahim Nasar speaks Arabic; when Santiago's mother is present, they switch to Spanish so that she is not excluded (García Márquez 1981: 16). Santiago feels drawn to both parents, but his phenotype is clearly 'branded' as Arab: For the slim, pale man who has just turned 21 possesses "los párpados árabes y los cabellos rizados de su padre” (García Márquez 1981: 15). Numerous 'orientalisms' are interspersed in the text, always patrilinear in their reference to his father, quasi as markers of identity, for his father had taught him not only how to handle firearms, but also 
how to hunt with falcons, to love horses, and instilled in him bravery and caution. ${ }^{18}$

Considering the exemplary character of his father, it is no surprise that Victoria Guzmán wants to spare her daughter Divina Flor the fate she once had suffered at the hands of Ibrahim Nasar: to be used as a sexual object, but then degraded to domestic servant while another takes on the position of official (although unloved) wife. When Santiago Nasar reaches for her beautiful daughter on the morning of his death, as he always did in what amounted to a standard routine, Victoria, long since aware that Angela Vicario's brothers and their knives are lying in wait for Santiago, threatens the blanco ${ }^{19}$ with a kitchen knife. A short time later she uses this implement to cut open a hare, whose entrails she throws to the dogs. A few hours later Santiago Nasar will collapse in this very same kitchen, with his belly cut open and intestines oozing out. As this "mise en abyme" of the entire plot of the novel makes clear, there is a direct connection between Santiago Nasar's violent death and the presence of his deceased Arab father, in his external appearance just as in the sexual relations he practiced. Do the gender relations in this tragedy, whose seemingly inevitable course is triggered by the hierarchical relations between man and woman, thus constitute that mediating level on which the lines of cultural conflict burst open and endanger peaceful coexistence?

First of all it must be stated that we are not situated in multicultural coexistence on the level of gender relations. At the very latest, the designation of Santiago Nasar as blanco draws our attention to the fact that we are not dealing here with marriage behavior characteristic of the ArabAmerican community, but with gender-specific patterns of behavior and forms of life which Santiago Nasar, in the machismo tradition, shares with the overwhelming majority of the male population in Colombia, his country of birth. What is more, the designation as 'white' unmistakably evokes social difference, that is, his belonging to a white aristocratic class and caste of leaders. Although San-

18 García Márquez (1981: 16): “de su padre aprendió desde muy niño el dominio de las armas de fuego, el amor por los caballos y la maestranza de las aves de presas altas, pero de él aprendió también las buenas artes del valor y la prudencia”.

19 García Márquez (1981: 19). Victoria’s daughter knows that, very soon - if only temporarily - she is destined for Santiago Nasar's bed: "se sabía destinada a la cama furtiva de Santiago Nasar” (García Márquez 1981: 19). 
tiago Nasar's cultural background may be more complex than that of the other residents of the town, he is nevertheless ensnared in the patriarchal world of values, which he clearly shares with Bayardo San Román, with the Vicario brothers and the narrator, as a matter of course. In a manner of speaking, the ArabAmerican influence of his patriarchal father cuts across the macho patterns of behavior shared by the entire population of this small town on the Caribbean coast of Colombia. In its overwhelming majority, it covers the murder of Santiago Nasar, proclaimed countless times and not prevented countless times, which takes place like an execution, right on the main square in front of everyone and in broad daylight, ${ }^{20}$ in a kind of subversion or parody of the locked-room puzzle. ${ }^{21}$ On the level of gender relations Santiago Nasar, by crossing different (gender) cultures, participates so to speak transculturally in the conditions that turn Bayardo San Román, Santiago Nasar and the Vicario twins into the protagonists of a tragedy, in which they are at the same time perpetrators and victims. Santiago Nasar, the son of an Arab migrant and a Spanish-speaking mother, does not represent a separable alterity, but an other in his self, that can not be assigned exclusively to his self, nor to the other, nor to a space in between. And even if he himself was not conscious of it even at the moment of his death: He embodies a world betwixt and between, which cannot be localized spatially - constituted by movements between different poles that can be ascertained but not fixed. In this sense the concept of 'strangeness' must be corrected in the declaration of one of the narrators the Lebanese writer Elias Khoury has concern himself with Santiago Nasar's death: "He experienced the strangeness at the instant of death, in that solitude which led him into spheres whose existence he had not thought possible" (Khoury 2000: 45). In the play between identity and difference, between Latin American and

20 Cf. the application of this concept to Leonardo Sciascia's novel Il giorno della civetta, where the murder takes place not in some hidden place, but, like in Crónica de una muerte anunciada, right at the beginning of the text on the main square and in the morning light, in Buschmann (2005: 57). Despite all diegetic and plot-specific differences, the parallels between the novels of Sciascia and García Márquez are obvious.

21 The fiancée of one of the two murderers later deposes that she never would have married Pablo Vicario, had he not acted as he did to save the family honor; as it was, she waited patiently for three years until Santiago Nasar's murderer was released before tying the knot (García Márquez 1981: 102). 
Arab worlds, Santiago Nasar stands for the complex entanglements and interconnectedness of the ArabAmerican, in whose 'world between' unfamiliarity and familiarity merge into one.

The gender-specific entanglements of the men apply in mirrored symmetry, in a reverse hierarchy, to the women as well, who play their culturally contingent role within the conflict of genders clearly developing in Crónica de una muerte anunciada. Angela Vicario is the youngest daughter of a family living in humble conditions, which is altogether representative for this diagnosis. ${ }^{22}$ Her father, Poncio Vicario, lost his sight while working as "orfebre de pobres" (García Márquez 1981: 50), and the corresponding precarity of the family's economic situation is what makes it possible for Bayardo San Román to use his money to "buy" the bride he happened to see one day and immediately desired. The bride's upbringing, for which her mother, Purísima del Carmen was responsible, was always divided genderspecifically and included strict sexual surveillance of the daughters to maintain the family honor, for: "Los hermanos fueron criados para ser hombres. Ellas habían sido educadas para casarse” (García Márquez 1981: 51). Thus it is no wonder that the mother of the narrator is convinced that these women would make their husbands happy, as they were raised to suffer from the day they were born (García Márquez 1981: 52). Angela's marriage to Bayardo is thus based on a double hierarchy, which takes both the gender relations and the socioeconomic situation into account. The will of the bride plays no role in this, for love can be learned as well: "También el amor se aprende" (García Márquez 1981: 56).

Nothing in the novel gives cause to the presumption that Santiago Nasar is actually responsible for Angela's lost virginity: The maternal supervision of the girl outside the home was perfect, and the investigating magistrate concerned with the case could not find any indications for this in Santiago's life, either. The narrator himself not only alleges that Santiago was much too stuck up to occupy himself with the girl; more importantly, he makes us profoundly aware that they had belonged to "two divergent worlds" ("dos mundos divergentes"

22 In this comprehensive sociocultural and gender-specific sense, the Vicario family, in keeping with its name - nomen est omen - would be a family of vicars, of "representatives". 
[García Márquez 1981: 144]). This remark is important, as it simultaneously provokes the question as to which divergent worlds are concerned here.

Not only the residents of the town in the novel, the representatives of research, too, never tired of developing the most widely diverging hypotheses about Angela's lost virginity. Could the narrator himself perhaps be responsible, ${ }^{23}$ such that his developing the detective story ultimately would amount to a perfect deception in order to divert any suspicion from himself to others? But then, to counter this thesis, why should he refer to this very 'divergence' of the worlds of Angela and Santiago? For if he were the perpetrator, it would have to be in his interest to exonerate himself and cast a negative light on Santiago. In another vein, some things in the context of the evident patriarchal gender domination also speak for the fact that Angela could have become the victim of sexual coercion or rape within the family itself, especially since the blindness of her father Poncio, with a view to Oedipus, at least suggests a proximity to violation of the incest taboo in terms of mythical and literary history. ${ }^{24}$

Yet Angela Vicario, too, is at once both victim and perpetrator. She had barely named Santiago Nasar as the guilty party when her brothers, pork butchers by profession, grab their knives. Why does Angela give the name of Ibrahim Nasar's son? Perhaps because, as is speculated in the novel, she could not count on her brothers to attack a rich man who possessed great wealth? Did Angela and Santiago belong to two diverging worlds in this economic sense? Or are the "mundos divergentes" perhaps marked culturally as well? When, at the end of the second of five chapters, or acts of this tragedy, her brother Pedro interrogates Angela, who has been abused by her furious mother, her answer comes amazingly quickly:

Ella se demoró apenas el tiempo necesario para decir el nombre. Lo buscó en las tinieblas, lo encontró a primera vista entre los tantos y tantos nombres confundibles de este mundo y del otro, y lo dejó clavado en la

23 This thesis appears to go back to a thought of Angel Rama's; cf. on this Silva (1998: 23).

24 Another factor that speaks for this is Angela's comment on the death of her father Poncio shortly after Santiago Nasar’s murder: “Se lo llevó la pena moral” (García Márquez 1981: 133). On this thesis, cf. especially Rahona/Sieburth (1996) as well as Pöppel (1999: 36sq.), and Silva (1998: 21sq.). 
pared con su dardo certero, como a una mariposa sin albedrío cuya sentencia estaba escrita desde siempre.

-Santiago Nasar- dijo (García Márquez 1981: 78).

The death sentence for Santiago Nasar comes as quickly as unexpectedly, and yet it was already written, had always been certain. Is it the artifice of the unconscious or of fate - as the investigating magistrate believes ${ }^{25}$ - or perhaps of a kismet that cannot be determined by man, but only interpreted in the sense of a divine will? In any case, Angela's answer materializes with the same suddenness and directness as her brothers' fears that the Arabs could poison them, and the residents' fears that the Arabs could burn the Vicario brothers alive. No less abrupt is the reaction of Yamil Shaium, the Arab shopkeeper who laughed about an Arab pun with Santiago Nasar just a few minutes before his death, in setting off with his large-game rifle to chase after the two murderers, supported by other, albeit unarmed Arabs. Pedro and Pablo Vicario fled into the secure sanctuary of the church (García Márquez 1981: 190), following that diagonal of death inscribed by a revolver bullet in the geometry of the town years previously, when an unintentional shot broke loose from Ibrahim Nasar's pistol, crossing the main square on which his son later was to be stabbed to death, and reducing to rubble a life-sized statue of a saint on the high altar of the Catholic Church located opposite (García Márquez 1981: 13). ${ }^{26}$

Just seconds before the murderous attack by the two brothers, a disinterested spectator calls out to the unarmed Santiago Nasar that the “Turk” should take a different path (García Márquez 1981: 184). Thus the son of Arab immigrants turns back from blanco to turco immediately before his death, from white landed proprietor to Oriental migrant. As if in response to all of this, in the face of death Santiago Nasar appears more beautiful than ever, with his "rostro de sarraceno con los rizos alborotados” (García Márquez 1981: 192). Santiago, often admired for his exceptional skill as a quick-change artist (García

25 On this, cf. García Márquez (1981: 180). There the investigating magistrate notes with red ink: "La fatalidad nos hace invisibles". Names and persons appear as out of nowhere and suddenly become invisible again, as if they were obeying a predetermined fate.

26 The narrator adds that Santiago Nasar would remember this lesson for the rest of his life; from then on he always kept his weapons separate from his ammunition. 
Márquez 1981: 106), is transformed by his public execution and death in front of everybody into a Saracen, an Arab.

In fractions of a second, so it seems, socio-cultural demarcations are activated, along with their associated mechanisms of exclusion and inclusion, which have not changed in any significant way even in the third generation, despite all of the Arab immigrants' attempts to conform to the resident population. Although Ibrahim Nasar gives his cattle hacienda the ostentatious name of "divine face" ("Divino Rostro") $)^{27}$ and no matter how much Santiago Nasar was able to donate to the bishop, whose ring he wanted to kiss: In the eyes of the citizens who do not have their roots in the Near and Middle East, the group of the 'Arabs' remained the 'Turks', the insulting designation assigned to their immigrated ancestors. Even if these 'Arabs' would not even think of committing the atrocities of which they are believed to be capable, hidden underneath the seemingly smooth coexistence are nevertheless faults and lines of conflict between the Spanish speakers and the speakers of Spanish and Arabic, which can break open at any time. Was the apostle Santiago, the 'true James' of all pilgrim legends on an Iberian peninsula still influenced by the Arabs, not also the patron saint of the Spaniards in the Reconquista's fight against the Saracens?

From the middle of the novel on, a peculiar dissemination of 'Orientalisms' - that is, textual elements that can be attributed to a specific 'Arabic' isotopy - can be discovered in unexpected places. Two examples of this should suffice. First, the investigating magistrate discovers that one of the two murder weapons the pork butchers used is a kind of miniature scimitar, an "alfanje en miniatura” (García Márquez 1981: 96). ${ }^{28}$ And when the narrator attempts to forget the horror by visiting the brothel's madame María Alejandrina Cervantes after Santiago Nasar's funeral, he finds the high-class prostitute carrying out her work of mourning: As always when she is terribly sad, she is stuffing unheard of amounts of food into her mouth and sitting in front

27 In spite of assurances of the narrator to the contrary, this name could also be an indication that Divina Flor, the daughter of Victoria Guzmán, is also the daughter of Ibrahim Nasar. Then, of course, a connection between Santiago and her would be an unconscious break of the incest taboo.

28 The narrator adds in explanation that no German knives could be imported at the time due to the war (García Márquez 1981: 95). 
of her "platón babilónico" completely naked, "a la turca" on her queen-size bed (García Márquez 1981: 124). It’s as if the woman with the great erotic aura, who had held the youthful Santiago Nasar so spellbound that his father once had to banish him to the hacienda for a period, is mutating into an Oriental. She is so very 'orientalized' that she has to break off her attempts to kidnap the love-hungry narrator into the land of love as a professional "bestia de amor" (García Márquez 1981: 125), as she still detects on her lover the dreadful stink of the body of Santiago Nasar, so cruelly cut open and quickly decaying.

Let us not forget that the perspective of the narrator, to whom the smell of his dead friend's decay is still clinging, is not an 'objective' position. His mother, Luisa Santiaga, may have been Santiago Nasar's godmother and the person after whom he was named, but he himself obviously is not one of the turcos. Of course, between the time of the story and the time he tells it, he marries into an Arab-American family himself, reporting to us outright that in the middle of Bayardo's and Angela's turbulent wedding party, he proposed to Mercedes Barcha, who had just finished primary school and was not yet of age. His later wife's reminding him of this proposal fourteen years later is a sophisticated autobiographical flashback, which also frictions the position of the text-internal narrator with that of the text-external, real author by the name of Gabriel García Márquez. For the flashback of the real author's wife, as an only seemingly incidental biographical datum, flags his position as a Colombian of non-Arab extraction who married a Colombian of an Arab immigrant family. The question is interesting, but may appear at first sight: How would this Crónica de una muerte anunciada have turned out if it had been presented to us by an 'Arab' narrator?

\section{Santiago Nasar's Murder from the Lebanese Perspective}

The Lebanese writer Elias Khoury, born in Beirut in 1948 to a family of Greek Orthodox faith, gives us a whole slew of possible answers to this question. For his novel published in 1994, The Mysterious Letter (Arabic: Magma' al-asrar), the title of which literally means "A Col- 
lection of Secrets”, ${ }^{29}$ refers explicitly to García Márquez’ Crónica de una muerte anunciada on multiple occasions and, in so doing, cleverly draws attention to the altered position of the observers with regard to the characters of the Colombian novel to which it refers. The narration, consisting of several short, self-contained stories, told by different narrators and intricately woven together into a whole, does in fact present different possible literary answers, or at least different techniques of telling the story from the Arab perspective.

The transareal shift in perspective departing from the Latin American cultural area is signaled in many ways. For instance, the description of Santiago Nasar submitted in Crónica as a slim and pale young man with "Arabic eyebrows" and "his father's curly hair" is cited precisely and associated with the appearance of an Ibrahim Nasar in Beirut, whose lover Norma describes him for her girlfriends from school. Yet Norma, as we find out, "did not speak of 'Arabic eyebrows', because she was Arab herself” (Khoury 2000: 37). With this the Arab internal perspective is designated clearly, not only of the unhappy lover, but of the entire novel, as evident in the various positions of its narrators. Thus The Mysterious Letter contains a message for García Márquez - and for his readers.

But what is the relationship between The Mysterious Letter and Chronicle of a Death Foretold? Elias Khoury's novel, too, starts right off with a puzzle: The greengrocer Ibrahim Nasar is found dead in his bed in a quarter of Beirut, while his lover, who is found half-naked in a wardrobe, screams and cries that she is lost. For the man who had promised her marriage and deflowered her could no longer marry her and save her from destitution.

The text, which plays with elements of a detective novel just as García Márquez’ Chronicle, not only features the shared surname, to which we will come back later; from the very beginning it presents a series of intersections which at first glance concern connections between murder and love, lost virginity and patriarchially influenced gender relations, and a puzzle structure underlying all strands of narra-

29 On this, cf. the fine survey study by Friederike Pannewick (2001). Cf. also the detailed interview with Elias Khoury in Mejcher (2001: 125-153), as well as Meyer (2001). 
tion. Elias Khoury joins quite intimately and elaborately the intertextual links between the two, short novels of similar length.

It is therefore no surprise that The Mysterious Letter also places the central questions of Crónica de una muerte anunciada in direct intertextual reference:

Everyone knew that Santiago was to be slaughtered this morning. Why didn't anyone warn him? Perhaps because they did not believe it, as they maintained. Or did they let him walk into a certain death because he was an Arab? Why was the immigrant Lebanese, who spoke Arabic although his mother did not master this language, allowed to die in this brutal manner? [...] Because he was a stranger? Does otherness mean death? (Khoury 2000: 37).

The very formulation of these questions makes the shift in perspective alluded to above apparent, first asking about a possible relationship between the murder and the Arab, or Lebanese, origins of the victim, while at the same time moving otherness to the center - which is certainly the central complex of issues in all of Elias Khoury's work. As a 'stranger in a strange land' Santiago Nasar did not go into raptures over the cockscomb soup of the locals, but like his father, preferred to eat cooked yogurt and drink tequila alias araq (Khoury 2000: 38). A strategy of writing takes form: Elias Khoury's novel picks up on the Arab elements contained in the Latin American reference text, intensifies them and develops them further in the transareal horizon of issues. Reading and writing, the reading of the other and the writing down of his own novel go hand in hand: at a very early date the Lebanese author claims to have discovered for himself that reading is a way of writing and writing a way of reading. ${ }^{30}$

With a fine writer's sense, Elias Khoury attempted to pick up on a number of the Arab or Oriental elements shown here and to weave these into a dense network of relations linking the two novels together. Each of the various partial stories, which are introduced from the first line of the novel by the opening formula "The story started like this" (Khoury 2000: 5), sheds a different light on the puzzle structure of the novel 'itself,' and often of the 'other' novel as well: In this manner the 'collection of secrets' heralded by the Arabic title does in fact emerge. The puzzles illuminate each other. It is no coincidence that the carnage committed against Santiago Nasar in Crónica de una muerte

30 Elias Khoury in Mejcher (2001: 131). 
anunciada reminds one of the narrators of the reports of Santiago's father Ibrahim Nasar, who had spoken "about the violence and the bloodbaths in the distant village with an unmentionable name" (Khoury 2000: 37sq.).

The connection thus produced at the start of the novel further unfurls at the end of the text in another of the complexly interwoven stories. Many long years ago, when Ibrahim Nasar was only ten years old, a letter had reported of the death of a distant relative in Colombia, thus frustrating with one blow all emigration plans of the relatives remaining in Lebanon, including Ibrahim himself. For evidently this letter, which Ibrahim was never to set eyes upon, instilled in everyone the fear that they could be persecuted as Arabs in Colombia and cruelly slaughtered just as Santiago Nasar was. Years later Ibrahim, disappointed by life, seeks traces of his own family history, hoping to find not only the golden treasure sworn upon time and again, but also the no less legendary letter from distant Colombia:

Besides, he believed he would come upon that mysterious letter with the report of Santiago Nasar's death, about which the Colombian author Gabriel García Márquez was later to write as if he were depicting the murder of Abd al-Djalil on the square in Ain Kisrin during the horrible bloodbath of 1860. As if he were depicting how Abd al-Djalil Nasar reeled under the blows of the short scimitars for an entire hour, how he tried to pick up his guts, which spilled out on to the ground, collapsed on top of them and died (Khoury 2000: 195).

With this, additional relationships between the two novels become apparent. For the mysterious letter that relayed the news of Nasar's death to Lebanon corresponds with a document in Crónica de una muerte anunciada that is no less mysterious: A warning written by an unknown man, whose identity never could be ascertained, contained in an envelope stuck under the door of Santiago Nasar's house. This letter contained very detailed information about the imminent murder, the reasons brought forward, the murderers themselves and the planned location of the crime (García Márquez 1981: 26). Yet Santiago, like all other residents of the house, simply overlooked the envelope lying on the ground, which was not found until after his murder.

Taken together, these two mysterious letters, which announced the death of Santiago Nasar in the two novels, merge together the two bloodbaths which were, in actuality, temporally and spatially quite separate, such that the description of the one slaughter can serve very 
well to depict the other. With this the settings in the mid-nineteenth and the mid-twentieth centuries, and in a small village in Lebanon and a small town on the Caribbean coast of Colombia, are made transtemporally and translocally congruent. In so doing, the Lebanese author did not neglect to "anticipate" temporally the "Arab" murder weapon brought into play by the Colombian author - as we saw - in the form of the scimitar, which the murderers in Lebanon used to commit their horrible massacre. Another slaughter is recognized as a kind of backdrop behind the carnage, whose bloody trace runs through history and the stories. This téléscopage reveals a glimpse of a history of migration extending over centuries, in which the hope for a fixed, definitive residence is smothered in a bloodbath over and again.

Consequently, in a first step the intertextuality established by Elias Khoury can be characterized on the spatial level, as a transareal relationship on the transcontinental scale. In view of both locations - which will be overlaid by even more locations of migration over the further course of the novel - it also bears a main characteristic that is translocal and rural. ${ }^{31}$ In other words: The Lebanese author links his text with the highly successful novel by a Colombian author, through which the Columbian diegesis is at once expanded translocally and transareally - and thus also has repercussions for the understanding of the reference text by García Márquez. At stake here is more than just writing the successive and preceding family history: Rather, Elias Khoury picks up on the elements of a history of migration in such a sophisticated manner that, in this translocal nature, a transtemporal and transareal network of relations emerges, cutting across different time-frames and spaces, not only making Colombia and Lebanon seem countries distant from each other, but also, in a vectorial sense, shifting the focus to the multifarious and complex movements between the two countries. Lebanon and Colombia are not simply the clearly distinct countries of origin and destination in a typical emigration history, but also stand in an intimate relation of exchange due to a multitude of indirectly and directly networked communications: What happens in one country has repercussions for the other.

31 Elias Khoury establishes an analogous translocal urban relationship between the city planning reconstruction program in Beirut and the intensive construction activity in Berlin; cf. the Lebanese author's statements in Borgmann (1996: 80). 
The structural homologies illuminated in this manner concern the omnipresence of violence, of slaughter and bloodbaths, of wars and civil wars, of flight and emigration, of social, economic and gender dependence. In the context of their areas, moreover, both countries are linked through their colonial history with European hegemonic powers, or, respectively, with the Ottoman Empire and the regional powers that established themselves after its collapse, and are marked by these asymmetrical relations. Despite all cultural differences, the theme of lost virginity shared by both novels further refers to patriarchal-style gender relations, which play a decisive role in the plot of both texts, by no means coincidentally. In this, the transcontinental and transareal relation between the Middle East and the Caribbean emphasizes the essential equivalence of different forms of potential for structural conflict, especially including the gender-specific and cultural-religious dimensions. Thus there is every reason to speak of an Arab-American network of relations that makes any restriction to a purely national perspective appear insufficient.

However, the central question, the riddle running through both novels, remains: How did it come to the bloodbath? One of the narrators employed by Elias Khoury makes a note of the fact that the village of Ain Kisrin was initially unaffected by the massacres spreading through the Lebanon Mountains (Khoury 2000: 159). In the village everyone continued with everyday life, as if these altercations erupting since 1858 and their horrible excesses simply did not exist. However, on February 12, 1860 the Abu Amer family was massacred at the edge of the village. And immediately "the village divided into two families" (Khoury 2000: 160), the Abu Amers and the Nasars, Druses and Catholics who had lived together well and peacefully until that time. Actually there had been "no occasion" for hostilities (Khoury 2000: 160); yet the know-how of coexistence that had been stable for so long - despite the bloodily disputed battles between the Maronite church and Druse feudal rule in the surroundings - imploded abruptly. Unproven allegations that a priest from the Nasar family was responsible for the massacre were enough for the men to slaughter each other with knives and send the village up in flames.

Locations, times and cultural contexts change; but unproven charges continue to display their devastating effect. The story of a man from the Nasar family who ran for miles with a knife in his back 
before collapsing to his death on the outskirts of Beirut foreshadows the final path of Santiago Nasar, cut open and brutally stabbed in his Colombian village: The stories, the places and times overlap, one bloodbath foreshadows the next. Memories "rise to the surface as if oozing from an old, unhealed wound" (Khoury 2000: 161). And thus not only the Nasar family thinks about flight and emigration:

Grandmother wanted to emigrate, everyone had dreamed of emigrating, and the ships setting sail for Marseille were crowded with people from the Western Bekaa Valley, from Zahle and from the mountains (Khoury 2000: 162).

And thus Nasar's path via Marseille to Latin America is in the offing. Since the devastating civil war of 1858/1860 - about which a young Elias Khoury once wrote a study at the Ecole Pratique des Hautes Etudes under the tutelage of Alain Touraine in Paris ${ }^{32}$ - many Lebanese had been forced to set out on this path. The colonial - or historical - constellations varied, yet it seemed that the series of civil wars in Lebanon would never end: all the way to the self-destructive civil war that began in 1975, leaving the country to bleed dry for decades. Elias Khoury himself had participated in this war as a militant combatant and recorded his terrible experiences in the novel The Little Mountain, published for the first time in 1977 (1989 in English). ${ }^{33}$ Without a doubt: Here there is a structural connection between the experience of the Colombian violencia described by Gabriel García Márquez and the battles in the Lebanese civil war described by Elias Khoury. Both novels are chronicles of proclaimed violence, which pose the burning question as to the puzzle of their respective emergence and toleration.

Back in Paris, young Khoury, as a student of sociology, certainly must have been aware that the descendants of the victims and survivors had laid by the horrors of the massacre starting in 1858 in the "the book of oblivion" (Khoury 2000: 159). This explains his endeavor to transform the necessity of historical science into the virtue of the novel, using the means of literature to expose the history and stories that had been neglected for so long. The young man, after taking up arms on the side of the Palestinian resistance after the Arab

32 Cf. on this the interview with Elias Khoury in Mejcher (2001: 131).

33 On the importance of this novel in the context of contemporary Arab literature, cf. the foreword to the English-language edition of Little Mountain by Edward W. Said (1989). 
defeat against Israel in 1967, ${ }^{34}$ learned his lesson from the bloody conflicts over the course of his own life, and has become a militant, uncompromising representative and advocate of literature and its importance for (not only Arab) societies. Militantly espousing literature is quite different from using literature as a vehicle for militant purposes and messages alien to literature. Khoury's deployment of literature is based on the insight that literature and life cannot be separated from each other and that ideology has no place in literature. ${ }^{35}$ The consequence of this is his project of writing, which learned the lesson of history and militantly advocates a life knowledge that feeds on the openness of literature, in order to keep history - and our own stories radically open.

The (hi)stories shown in literature create and contain their own deceits. It is thus quite possible that the Catholic priest Abdallah Nasar, whom some blamed for the massacre in Ain Kisrin, is the very one who became the ancestor of the Colombian Nasars. He had fled to Beirut, from there to Marseille and finally further to Colombia, where he then is supposed to have founded "the emigrated branch of the family" (Khoury 2000: 159). A religious fanatic and provocateur as progenitor? Were his entanglements ever revealed, or did they flow into the "Book of Forgetting"? But how, in the tradition of forgetting and suppression, to halt the cycle of violence and the bloody recurrence of what is suppressed?

Just a century later - if Elias Khoury's narrator characters are to be believed - the mysterious letter with the news of Santiago Nasar's slaughter in Colombia will call to mind this almost forgotten, suppressed Lebanese (pre)history and frustrate all travel plans of the family of Ibrahim Nasar, the future greengrocer. Ultimately it becomes clear that the family patriarch Jakob Nasar has not entirely forgotten the bloodbath of Ain Kisrin and has a ready explanation for the brutal events: The curse of Abd al-Djalil, who - as we have seen - collapsed

34 On this, cf. Elias Khoury's interview with Mejcher (2001: 129): "When I entered university, the June war of 1967 broke out. It changed my life". In very similar terms, the Palestinian literature and cultural theorist Edward W. Said summarized the experience of this generation, as he, too, spoke of the Israeli defeat of Arab troops as a turning point in his life; cf. Said (1999: 101sq.).

35 Elias Khoury in Mejcher (2001: 134). 
under the blows of the scimitar, continues to pursue the family (Khoury 2000: 163).

\section{Four Times One Hundred Years of Foreignness}

The history of the family - and thus the history of the atrocities - goes back even further, of course. Ibrahim Nasar, whose murder opens the volume, knew it only vaguely from hearsay. What is known, however, is that the family was originally called Atwi and first received the sobriquet Nasar in Ain Kisrin. The family, which presumably originally came from Izra' in Hauran - so the stories say - long ago emigrated to Kana in southern Lebanon, in stages over a period of two hundred years. The last to emigrate, at the end of the eighteenth century, were the members of the branch that was to receive the name Nasar, and the reason for this was - what else - a murder, whereby this time "the emigrant was not the perpetrator, but the victim" (Khoury 2000: 25). Bedouins from the Golan Heights had attacked the family and killed three brothers; back in far-off Kana such an act had already compelled the Atwis, emigrants since the late sixteenth century, to convert to Islam in order to forestall further attacks. Although it is not possible to trace all of the details of the history presented as fragments in the novel, it is nevertheless apparent that the migration from Lebanon to Colombia was merely a new stage in a centurieslong succession of murders and emigrations, each of which involved further massacres and waves of refugees. Thus the younger generation in Elias Khoury's novel may no longer try to flee to Colombia, Venezuela or Mexico, but rather to Canada, since Canadian authorities are issuing immigration visas for Lebanese Christians after the most recent Lebanese civil war. ${ }^{36}$

This changed destination for emigration, no longer to the South, but to the North of the American continent, is merely a sign for the modified (and historically comprehensible) factors pulling ArabAmerican immigration in the face of ultimately unchanged factors pushing emigration. Migration upon migration - and always the danger of seeing the coexistence established with so much effort sinking

36 On this, cf. Khoury (2000: 15, 209, 214). 
into a bloodbath, which, in turn, triggers new migrations - or prevents them elsewhere.

Here Elias Khoury links the endless succession of ever new migrations with the leitmotif of foreignness and otherness running through all of his texts, for it is not difficult to recognize that "it does not require any emigration or expulsion from paradise to be foreign" (Khoury 2000: 54). Indeed, it is certainly possible for man "to be a stranger in his own house and among his own neighbors" (Khoury 2000: 54).

In 1993, a year before The Mysterious Letter was published, Elias Khoury had already developed this leitmotif in equally poetic and multi-faceted form in his novel The Kingdom of Strangers (first English edition in 1996). It sounds like a mixture of intra- and intertextual references for Khoury to pursue the topic of foreignness from Gabriel García Márquez' character Santiago Nasar in Colombia, via Albert Camus' character of the stranger (Meursault in L'étranger) in Algeria, via his own novel's characters in Lebanon back to Adam, the ultimate father-figure. Adam was not only "the first foreigner", but also "the first Arab poet" and "the first human" (Khoury 2000: 42) - just like Camus' Le premier homme. ${ }^{37}$ He spoke the first language, "the language of Paradise and of Hell” (Khoury 2000: 42), which was, however, pursued by "the curse that ripped language apart in the Tower of Babel” (Khoury 2000: 42), just as the country lapsing into the Lebanese civil war in 1860 was transformed "into the Tower of Babel" (Khoury 2000: 160). From this time on people face each other as strangers, no longer speaking the same language and unable to find a way out of their Babylonian confusion of languages.

Not only does Khoury skillfully resort to the points of reference frequently interspersed in the text from the literatures of the twentieth century, as well as to Ancient Arab poetry and to stories from The Arabian Nights, but, in the tradition of world books, he also introduces the Bible and the Koran, in whose stories and figures the characters of Elias Khoury, the writer between cultures, are reflected time and again. Thus in his novel The Kingdom of Strangers, the question "What am I writing?" is followed by not only a timid response indica-

37 This text from Albert Camus estate was published by Gallimard in Paris in the same year as The Mysterious Letter. 
ting the insecurity of the narrator as well as of narration ("I don't know. I feel the words decaying and disintegrating" [Khoury 1996: 39]); but by a vision of Christ at the Dead See:

Yet I see him today, in 1991, at the close of a barbaric century, which started with a massacre and ended with a crime. I see him, lonely, dead, crucified. He is walking on the water.

The only one who is a foreigner.

A stranger in the realm of strangers, which he, or so the white Cherkessian believed, wanted to found (Khoury 1996: 39sq.).

Widad, the "Cherkessian", sees Jesus Christ as the quintessence of a stranger, in which her own image is reflected. The fact that the white Cherkessian is not a Cherkessian, as the Lebanese world around her and she herself believe, but rather a woman who was kidnapped as a young girl from her native village in Azerbaijan, enslaved and finally sold to Lebanon by way of Alexandria (Khoury 1996: 43), may explain why Widad begins to sing "The Stranger" with such fervor during religious services (Khoury 1996: 40). In the kingdom of strangers everyone - as victim or perpetrator - is a stranger to everyone else: having stirred up dust in countless migrations without any real origin and without a real future, time and again forced to laboriously build up a life knowledge that is good for the know-how of peaceful coexistence, at least for a time. Yet often an unforeseen coincidence is enough to set off the kind of chain reaction that so brutally characterized the twentieth century, and that already seems to be defining the twenty-first century as well.

Widad, stolen from her native village, will make herself understood in a foreign language her entire life, until she loses the mastery of this language foreign to her along with her memory at the end of her life: a Babylonian confusion of languages "in nuce". This devoted, self-sacrificing, and yet unfathomable character - one of the most beautiful, most lovingly created female characters in the author's fictional work - has long since been transformed into "a history of silence" (Khoury 1996: 98). But what does this history of silence have to do with the history of writing?

When the first-person narrator tells Widad's story to Salman Rushdie in London in 1988, the author advises him to turn it into a novel. Yet the narrator confesses his fear, the fear of "being pushed to the edge or devoured by the story", or even "becoming part of the 
story without knowing how it will proceed and turn out" (Khoury 1996: 98). For the narrator, Rushdie himself serves as the best example for the fact that such fear is warranted, as Rushdie had not sensed, back before the publication of his Satanic Verses, that writing was to become "his undoing" (Khoury 1996: 99). All the greater the risk for an author who emigrates to London at the age of sixteen, writes his novels not in his native Urdu, but in English, and ultimately, like Widad, forgets the foreign language he learned in old age, so that in the end he will not even be able to read his own books! (Khoury 1996: 99).

Obviously, this story gets under the skin of the narrator - whom we cannot simply equate with Elias Khoury. It is too horrible not to be true. Incorporating Salman Rushdie into The Kingdom of Strangers introduces a frictional dimension, oscillating between the fiction internal to the text and the reality external to the text, which at the same time possesses a metafictional status reflecting upon the fiction of the novel. Yet what is contemplated in these passages is not only the fiction, but also this friction, so that at the same time one can speak of a metafrictional dimension. Here Salman Rushdie embodies the writer, who literally left his fatherland and his mother tongue, and who stands for the kind of writing without a fixed residence that strikes fear into the heart of the first-person narrator. The fact that tales can devour the people who tell them, and thus commit literary cannibalism against their creators, is demonstrated with extreme clarity in the example of men of letters writing without a fixed residence:

I remember saying to Rushdie that his choice would make him a potential hero of one of his novels some day. I had no idea that a life of suffering was in store for him, more terrible than any a hero had ever lived through (Khoury 1996: 105).

The warning to the writer is crystal clear: Bear in mind - you may have to live through what you write. Literature and life cannot be separated from each other, are so intimately related to each other, they evoke the fear that literature - as in Jorge Luis Borges' Tlön, Uqbar, Orbis Tertius - could force its way directly into life and change it. ${ }^{38}$

38 Cf. this text by the Argentinean writer in the horizon of frictionality with Ette (2001b: 227-268). Elias Khoury made a quite concrete and unpleasant experience with the "penetration" of a story written by others into his own life in France in October 2001, just a few weeks after September 11; on this, cf. Khoury (2001). 
The metafictional and metafrictional passages in Khoury's The Kingdom of Strangers also include reflections about "the contemporary literature of the Third World" - which Western eyes all too readily dismiss as "unreliable" (Khoury 1996: 104). Yet how, the firstperson narrator asks insistently in view of his narrated time and narrated situation in Lebanon, can we "combine and link together [the scattered stories] in a country in which all connections have been annihilated?” (Khoury 1996: 105sq.). There is good reason for Edward W. Said to emphasize that writing novels in societies as torn apart as those of Palestine or Lebanon is something very risky and highly problematic (Said 1989: xiv). In fact, Lebanese literature in particular offers an impressive demonstration of the way categories like national literature and world literature lose relevance as they no longer can be applied as descriptive elements. ${ }^{39}$

Yet the polyglottism and worldwide dispersion of such a literature without a fixed abode - which in many senses probably could best be compared with Cuban literature in the New World - does not mean that it loses any explanatory power, credibility or "authenticity" at all. Nevertheless, from the perspective of such a transcultural and transareal Lebanese literature, the question of truth is posed even more keenly, as it intends to consign and surrender its own painful history neither to the "Book of Forgetting" (Khoury 2000: 159) nor to the interests of certain ideologies. But how - as Khoury's narrator characters ask over and again with often agonizing persistence - can the danger of unreliability be countered, how can the truth be found and represented in a literarily convincing manner?

In today's "age of documentation” (Khoury 1996: 122), documentation for this age can hardly be the answer to such a question. Latin American authors, as the narrator knows, draw their "legends of the present from oral tradition” (Khoury 1996: 122), a method employed by many a story of Elias Khoury's before. Yet in response to his lover Maria's question of what truth is, back in the first part of the novel the first-person narrator found an answer that is characteristic of Khoury's profound humor, and disconcerting only at first glance: "The conjunction of two lies” (Khoury 1996: 37).

39 On this, cf. Pflitsch (2003). 
Writing, as not only Khoury's writer characters know, "means lying” (Khoury 1996: 66). Therefore, it could be formulated, the meeting of two written stories like Chronicle of a Death Foretold and The Mysterious Letter represents the literary meeting of two lies. But this, as we now know, drives the truth out into the open.

But which truth is at stake here? Thanks to Elias Khoury's story, Gabriel García Márquez’ character Santiago Nasar can now look back on a history of not only one hundred years of solitude, but also of four hundred years of restlessness, of emigration and violence, so that the proclamation of his death is, in essence, shifted hundreds of years into the past, where it can be read between the lines of those oral histories that attempt to preserve in people's memory a family history as a history of migration. As we know, the history of the Colombian Santiago Nasar is based on a true story, which García Márquez transformed into his story three decades later. For his part, Elias Khoury transformed the story told by García Márquez into a story that tells of the foreignness of man, in a succession of murder and migration that appears hopeless and without end. Man appears as a prisoner of his own foreignness, as a stranger among strangers, who can attack, slaughter and devour each other at any time. But is there really no escape from the spiral of expulsion and emigration, violence and counter-violence?

\section{ArabAmerican Writing between Worlds}

For the novels of Elias Khoury, the strangeness and otherness of man is of fundamental importance - as was to be shown here. Nevertheless, despite the clearly accentuated transhistorical continuity of the cyclical time structure so frequently observed in his works, especially on this level of meaning, the structure does not entail an ahistorical perspective of an ontology of strangeness in the kingdom of strangers, detached from time and space. Even the connection between massacre and migration is by no means given and obligatory once and for all. A renewed look at the double network of specifically ArabAmerican relations, cleverly interwoven by García Márquez and consequently developed further by Elias Khoury, can elucidate this.

In this we should proceed first from the observation that the news of the murder of young Santiago Nasar, so to speak, on the boundary between Chronicle of a Death Foretold and The Mysterious Letter, 
does not trigger any migrations. The family of the perpetrators is urged to leave the location of the murder, yet the population of Arab extraction settled in the small town endeavors not to endanger the way they live together with the other Colombian residents through acts of vengeance. Rather, the representatives of the Arab community, filled with deep mourning, emphasize their renunciation of violence and attempt to secure future peaceful coexistence with a gesture of good will, by sending medicinal herbs to Santiago's murderers. They do everything to avoid a collision of cultures.

In Elias Khoury's novel, the news of the death of a grandson of Lebanese immigrants results in the cancellation of all emigration plans, as the members of the branch of the family remaining in Lebanon apparently interpret the collectively committed murder as the sign of a collision which could be understood in the sense of a "clash of civilizations". While the Arab migrant families that have since taken up residence in Colombia draw the lessons from their story, as from their own family history (which can be read as the succession of massacres and migrations), the Nasars in Lebanon are conscious of the same family history and no longer believe that they will be able to escape such a history through emigration. Nevertheless they remain the prisoners of a history that seems to repeat itself over and again. For it is no accident that the time period central to the novel, which begins with multiple references to the founding of the state of Lebanon in 1943 (and consequently with the promise of a new chapter of postcolonial history), ends with the year 1976 and thus amid a new cycle of violence and counter-violence, of bloodshed and revenge, of massacre and counter-terror. The death - or murder - of the greengrocer Ibrahim Nasar in 1976 saves him - as the narrator tells us - from having to live through the renewed bloodbath that was to take place in Ain Kisrin and the surrounding villages once again in 1983 (Khoury 2000: 169).

For Elias Khoury, who was not only working on his novel The Little Mountain but also fighting in the civil war in 1976, the year in which his later hero Ibrahim Nasar died, the exit from the spiral of violence started on January 20, 1976. This was the date of a massacre committed by Palestinian freedom fighters against the Christian residents of a small town south of Beirut, which was unmistakably intended as an act of revenge for the atrocities committed by Christian 
militias against the population of Palestinian refugee camps a few days earlier. Elias Khoury saw in this horrible experience the actual cause for his "exit" from the ideologically motivated "logic" of the civil war:

It was the crucial moment when I discovered that our ideology did not protect us from behaving in a savage, fascist way. What is the meaning of all our discourse and all our ideology if we kill children, women and men because they are Christians or Muslims or whatever? ${ }^{40}$

The writer grew up in a district of Beirut with a majority Christian population and came from a Greek Orthodox family. Taking up the Arab cause at an early age, he joined the Palestinian resistance in Jordan and received military training in a PLO camp in Syria. The scenario of mutual murdering on the basis of different religious affiliations appeared to him no longer justifiable with reference to a 'just cause', a 'just war'. From this point on, the Lebanese author developed the hopelessness of such a suicidal cycle, not only in his life, but also in his body of literary work.

Insofar his novel The Mysterious Letter not only outlines the centuries-long entanglement of the Nasar family as both perpetrators and victims in a history of murder and migration, but also shows the life knowledge and survival knowledge yielded by this history to the family members who emigrated to the New World. In terms of literary theory, his novel can be understood as an allograph, that is, a continuation of Crónica de una muerte anunciada written by a 'foreign' author, whose spatial-temporal extension of the diegesis into the nineteenth century and to the Middle East effects a transareally-grounded resemantization of the reference text. Through this, Santiago Nasar no longer appears only in the light of a Latin American author from the Colombian perspective, but at the same time in the writing of an Arab novelist from the Lebanese tradition. As a consequence, the two novels begin combining into a shared history.

The true importance of this ArabAmerican experiment is located in this meeting of the two fictions. For literature becomes the place of movement, at which the allographic continuation of a reference text becomes an embedded record of different cultures and their (hi)stories. This transcultural, embedded writing, for its part, opens up a kind

40 Elias Khoury’s interview with Mejcher (2001: 133). 
of 'writing between worlds', which can be understood neither from the national literary perspective nor as world literature. For it does not concern static, literary territories, but rather vectorial ways and strategies of writing in the horizon of transareal patterns of movement. Hence the conjunction of the two novels could be described as Yoko Tawada explained the encounter of an original Paul Celan text with its translation: In the case of an optimal translatability, this encounter is not generated for the first time in its translation, but always already instilled in the 'original', in the text that came first chronologically (Tawada 1996: 129). In this very manner, García Márquez’ Crónica de una muerte anunciada always contained its Arab-American continuation. The truth of both novels lies in the fact that each has always contained within its 'own' body of text the interstitial world of the other, 'foreign' text.

The transareal intertextuality aspired to by Elias Khoury thus shifts into consciousness a writing between worlds, which does not necessarily presuppose that it can be applied to a kind of writing without fixed abode - although the Lebanese author has commuted regularly between the Middle East, Europe and the United States for years. What it certainly does require is a high degree of familiarity with different cultural and religious contexts, which must not be 'written together', but embedded within each other. Transculturally cutting across Eastern and Western, Christian and Muslim, Arab and American horizons of cultures thus illuminates new configurations of meaning in García Márquez' complexly structured world of characters surrounding Santiago Nasar.

The interplay between Chronicle of a Death Foretold and The Mysterious Letter elucidates the way in which a transareal scholarship, interested not in fixed spaces and territories, but in movements and mobile entanglements, can develop a new relationality, which is neither limited to a local or national perspective nor 'dissolves' into general, global contexts. This intertextually generated oscillation between different logics reveals a history of multiple migrations behind the character of Santiago Nasar and the members of his Arab (better: Arab American) community, which takes on the form of a specific life knowledge marked by the history of the Middle East. The family's migration to Colombia essentially delocalized this knowledge - as the excerpt from Luis Fayad's novel also showed, for at the same time 
this delocalized knowledge supplied not only multicultural, but also inter- and transcultural areas of application and latitude.

The transformation of delocalized knowledge into a translocalized knowledge, by constantly translating the experiences between land of origin and land of destination into each other and generating selfsimilar fractal patterns of transcultural practice in the sense of a "mise en abyme", by no means excludes the possibility that certain events in the country of immigration could foster a combative logic of cultural collision $^{41}$ or a "clash of civilizations". In a discrete, but by no means concealed manner, Crónica de una muerte anunciada demonstrates how an element belonging equally to the patriarchal gender orders of both the Hispanic and Arab traditions - the problem complex of "lost" virginity - can evoke seemingly hidden lines of cultural confrontation and make them virulent. Even in García Márquez, the fact that Santiago Nasar was not able to make himself aware of these fault lines, which were hardly invisible in their explosive danger and would ultimately extinguish his own life, may certainly be interpreted as a warning that the societal integration of migrants should never be seen as concluded, not even in the third generation, and that cultural heterogeneity should not be conceived of exclusively as a cultural fortune, but also as a potential conflict ready to split open at a moment's notice.

However, at the same time it becomes clear how much cognitive potential is located in a literature that can be designated as Arab American in the fullest sense of the word. For while the Colombian author transformed us into only seemingly uninvolved spectators of a proclaimed execution, whose reasons would not hold up to scrutiny even beyond the Caribbean coast of Colombia, the Lebanese writer presented us with a succession of violent acts that seemed never to stop, out of which he dissected the mechanisms of a society's selfdestruction, which can be observed not only in Lebanon.

Among the multifarious publicistic activities for which Elias Khoury, whom Edward W. Said certified a "fundamentally postmodern literary career" (Said 1989: xvii) - an oversimplification from today's perspective - was responsible during a decade as editor of a leading publishing house in Beirut, was the translation into Arabic of a

41 Cf. on this term and its historical manifestations Bitterli (1982: 130-160). 
multitude of "major postmodern Third World classics" (Said 1989: xvii). Not least among these postmodern, Third World Classics were the Latin American authors Miguel Angel Asturias, Carlos Fuentes and, of course, Gabriel García Márquez. ${ }^{42}$ No wonder: authors of the Latin American "boom" have enjoyed unbroken popularity in Arab countries for a long time. In view of the "Declaration of Brasilia", we could say that Khoury thus made an active contribution to the establishment of a "Latin American-Arab Library" avant la lettre, in the sense of translating and propagating Spanish-language texts in the Arab-speaking world.

While there is no doubt that Khoury's previous activities could be designated as "intercultural", he opened the door for his work to enter the "Arab-American Library" himself with The Mysterious Letter, a book that bears unmistakably "transcultural" characteristics. An "Arab American Library" understood in this sense, which would include texts by Elias Khoury and Luis Fayad just as Gabriel García Márquez' Chronicle of a Death Foretold, opens up a new dimension of an Arab American 'writing between worlds', which would be important not only for uncovering a history believed to have been forgotten, but far beyond the political visions of the summit of Brasilia with regard to its potential for the future. The life knowledge stored and kept available there, because it is evidently bound to life, is important for our survival, especially in an atmosphere that is characterized more than ever by the thesis of a "clash of civilizations". For we should be aware on the one hand "that only through telling stories does the past become extant" (Khoury 1996: 10); on the other hand we may not forget that unavoidable truth of which The Kingdom of Strangers reminds us: ${ }^{43}$ In order to be able to tell a story, one must first survive it. Accordingly, in this both physical and narratological sense, literature is always not only life knowledge, but survival knowledge.

42 At least in the original plans, because Márquez was then published by another editor.

43 Khoury (1996: 36): "Faisal did not tell any more stories, for he did not survive the next one". 


\section{Bibliography}

Agamben, Giorgio (2002): Homo sacer. Die souveräne Macht und das nackte Leben. Translated from the Italian into German by Hubert Thüring. Frankfurt/Main: Suhrkamp.

Bitterli, Urs (1982): Die “Wilden” und die “Zivilisierten”. Grundzüge einer Geistesund Kulturgeschichte der europäisch-überseeischen Begegnung. Munich: Deutscher Taschenbuch Verlag.

Borgmann, Monika (1996): “Städte sind wie Geschichten”. In: Die Zeit 45, p. 80.

Brittain, Victoria/Slovo, Gillian (2004): Guantanamo: "Honor Bound to Defend Freedom", taken from spoken evidence. London: Oberon Books.

Buschmann, Albrecht (2005): Die Macht und ihr Preis. Detektorisches Erzählen bei Leonardo Sciascia und Manuel Vázquez Montalbán. Würzburg: Königshausen \& Neumann.

Chwals, Kaya J. (2005): “Guantánamo - Honorbound to Defend Freedom - Review”. In: OffBroadway <http://www.offbroadway.com/reviews/guantanamo.htm> (5/25/2005).

Declaración de Brasilia. Cumbre América del Sur - Países Arabes (10-11 de mayo de 2005). <http://www2.mre.gov.br/aspa/Decl/espanol.doc>.

Ette, Ottmar (2001a): “Kuba - Insel der Inseln”. In: Ette, Ottmar/Franzbach, Martin (eds.): Kuba heute. Politik, Wirtschaft, Kultur. Frankfurt/Main: Vervuert, pp. 925.

- (2001b): Literatur in Bewegung. Raum und Dynamik grenzüberschreitenden Schreibens in Europa und Amerika. Weilerswist: Velbrück Wissenschaft.

Fayad, Luis (2000): La caída de los puntos cardinales. Bogotá: Editorial Planeta Colombiana.

García Márquez, Gabriel (1981): Crónica de una muerte anunciada. Barcelona: Editorial Bruguera.

García Usta, Jorge (1997): “Arabes en Macondo”. In: Deslinde 21, pp. 122-139.

Hofmeister, Wilhelm (2005): "Ein Gipfel der falschen Erwartungen und des falschen Zungenschlages. Das 1. Gipfeltreffen Südamerika - Arabische Liga”. In: Focus Brasilien 4, pp. 1-7.

Huntington, Samuel P. (1996): The Clash of Civilizations. New York: Simon \& Schuster.

Khoury, Elias (1996): The Kingdom of Strangers. A novel. Translated from the Arabic by Paula Haydar. Fayetteville: University of Arkansas Press.

- (2000): The Mysterious Letter. A Novel. Translated from the Arabic by Leila Chammaa. Munich: C. H. Beck.

- (2001): "Wie der Westen Araber produziert. Erfahrungen eines libanesischen Schriftstellers mit der französischen Polizei - und drei Gründe, nicht zu reisen”. In: Die Zeit 47, p. 46.

Mejcher, Sonja (2001): Geschichten über Geschichten. Erinnerung im Romanwerk von Ilyas Huri. Wiesbaden: Reichert. 
Meyer, Stefan G. (2001): “The patchwork novel: Elias Khoury”. In: The Experimental Arabic Novel. Postcolonial Literary Modernism in the Levant. New York: SUNY Press, pp. 129-140.

Pannewick, Friederike (2001): “Elias Khoury”. In: Arnold, Heinz Ludwig (ed.): Kritisches Lexikon zur fremdsprachigen Gegenwartsliteratur. $54^{\text {th }}$ edition. Munich: edition text + kritik.

Pelayo, Rubén (2001): “Chronicle of a Death Foretold (1981)”. In: Gabriel García Márquez. A Critical Companion. Westport, Connecticut/London: Greenwood Press, pp. 111-133.

Pflitsch, Andreas (2003): "Literatur, grenzenlos. Aspekte transnationalen Schreibens”. In: Szyska, Christian/Pannewick, Friederike (eds.): Crossings and Passages in Genre and Culture. Wiesbaden: Reichert, pp. 87-120.

Pöppel, Hubert (1999): “Elementos del género policíaco en la obra de Gabriel García Márquez”. In: Estudios de Literatura Colombiana 4, pp. 23-46.

Rahona, Elena/Sieburth, Stephanie (1996): “Keeping Crime Unsolved: Characters' and Critics' Responses to Incest in García Márquez' 'Crónica de una muerte anunciada””. In: Revista de Estudios Hispánicos 30, pp. 433-459.

Said, Edward W. (1989): “Foreword”. In: Khoury, Elias: Little Mountain. Manchester: Carcanet Press Limited, pp. ix-xxi.

- (1999): "No Reconciliation Allowed”. In: Aciman, André (ed.): Letters of Transit. Reflections on Exile, Identity, Language, and Loss. New York: The New Press, pp. 87-114.

Schlickers, Sabine (1997): Verfilmtes Erzählen. Narratologisch-komparative Untersuchung zu "El beso de la mujer araña" (Manuel Puig/Héctor Babenco) und "Crónica de una muerte anunciada” (Gabriel García Márquez/Francesco Rosi). Frankfurt/Main: Vervuert.

Silva, Armando (1998): "Encuadre y punto de vista: saber y goce en 'Crónica de una muerte anunciada'”. In: Universidad Nacional de Colombia/Instituto Caro y Cuervo (eds.): XX Congreso nacional de Literatura, Lingüística y Semiótica. Memorias. "Cien años de Soledad”, treinta años después. Bogotá: Universidad Nacional de Colombia, pp. 19-30.

Tawada, Yoko (1996): “Das Tor des Übersetzers oder Celan liest Japanisch”. In: Talisman. Tübingen: Konkursbuchverlag Claudia Gehrke, pp. 121-134.

Zimic, Stanislav (2001): "Pundonor calderoniano en Hispanoamérica (con ilustración en Crónica de una muerte anunciada de García Márquez)”. In: Acta Neophilologica XXXIV, 1-2, pp. 87-103. 


\section{Alberto Ruy-Sánchez \\ The Nine Gifts that Morocco Gave Me}

For more than twenty years I have been writing a cycle of novels, poems and short stories that take place in Mogador, a walled Moroccan port on the Atlantic coast, two and a half hours from Marrakech. Since 1953, its official name has been Essaouira, but people still continue to call it Mogador. Considered one of the entrances to the Sahara desert, it was like an "almost island" between two oceans, one a sea of sand.

For many Mogador was like another continent almost out of Africa. A very unique city where a Jewish baby and a Muslim baby could be nourished by the milk of the same wet nurse. A place where different black Africans from south of the Sahara and at least two white African groups, the Berbers and the Arabs, mixed, creating an "animistic-islamic" ritual culture known as the Gnawa. Today Gnawa music is one of the deepest cultural traditions in Mogador, and there is also an interesting movement of naif Gnawa painting. Mogador is a town where talented artisans, specializing in woodcarving and silver jewelry, create masterworks of wonder. Until the middle of the nineteenth century, Mogador was a bustling international commerce port which linked South and North Africa with Europe and harbored a small but dynamic European community that conducted commerce with diplomacy. Mogador was an impregnable walled port designed by a French military architect inspired by the walls of Saint-Malo, but at the same time, it remained a fragile city possessed by fierce winds and surrounded by dunes that threatened its existence each afternoon.

But why does a Mexican feel compelled to write about Morocco? ${ }^{1}$ This is a question that arises so many times, especially in the northern countries that I visit. My answer is a complex one, even though it

1 Ruy-Sánchez (1987; 1993; 1994; 1996; 1999; 2001a; 2002; 2005). 
should not be; even though I should be able to answer quite simply: why not? The origin of this question stems from implicit biases against what I have been writing over the years. A narrow way of regarding a writer's place in the world, especially when he comes from another third-world country. A very simplistic attitude toward the very complex reality that defines our identities.

What Morocco gave me is much more than an interesting location for my stories, as some people tend to believe. And certainly not a northern fascination for the exotic south, described by Edward Said as Orientalism. I come from another south, and that changes everything, allowing me to develop the theory of a possible south-south relationship which I ironically term "Horizontal Orientalism" (Ruy-Sánchez 2001b). What Mogador gave me was a new way of understanding the world and myself. My Moroccan friends have been crucial in this endless quest for understanding. And through my writing, Morocco has gained a special place in my work and has added a new dimension to my life.

My first trip to Mogador became a much longer and deeper journey. First came the shock of discovering a place that in spite of being so distant from Mexico provoked a strong impression of recognition, much greater than the one a Mexican receives upon arriving to Spain. A combination of body language, place, and objects made me feel that I had ventured into another Mexico. My first steps into the marketplace showed me that so many of the marvelous crafts that we consider a part of our Mexican identity were nearly identical in Morocco. For more than two months, my wife and I discovered astonishing parallels between beautiful objects, arid landscapes, and labyrinthine minds.

The surprise was duplicated when some Moroccans told me that they had the same impression when they arrived in Mexico: a thread of identification, a common vein, sometimes subterranean, sometimes evident, even in the midst of so many differences. There is an historical explanation behind that impression, one which runs counter to our most common national ideology in Mexico. Our legacy derives from five centuries of mixing Indian and Spanish blood, but we must not overlook the Arabic heritage running through our veins, introduced by the Spaniards. We must not forget that for eight centuries two-thirds of what is now Spain and Portugal was Arabic: the Anda- 
lusí civilization, not to be confused with present-day Andalusia. In fact, their culture was Arabic, but originating from the Berber population that migrated from North Africa to Spain in two mass exoduses. Playing with the equivocal ideological terms on which we were educated, I would venture to say that we Mexicans also descend from Berbers, the oldest population that inhabited North Africa before the Arabic conquest of their territory and their faith. Perhaps some Mexicans may attribute their dark skin to their Arabic origin rather than to their indigenous heritage.

Catholics, Jews, and Arabs lived together for centuries in Spain, sometimes fighting and sometimes sharing that territory, and many times at war with each other, persecuting and disapproving of each other. But there were many small kingdoms, Reinos de Taifa, city states that survived by making alliances against common enemies, changing sides, and sealing alliances through marriage. The consequence after centuries is a deeply mestizo population whose real origins cannot be clearly traced. Often these origins are finally decided by powerful political, racial, and religious institutions, or by war.

The conquest of America by a few soldiers cannot be understood without considering these war-alliance dynamics, not to mention germs and guns. The Quechua Empire in Peru was larger than all of Europe, and the Aztec empire was also a big and powerful one, but the few Spanish conquistadors made alliances with the innumerable enemies in the territories of those American emperors. They married the women of their allies, as they did in Spain, and thus began a very active mestizaje.

Although the discovery of America coincided with the expulsion from the Iberian Peninsula of the Andalusí armies to Morocco, many people remained mixed, perhaps converted to Catholicism, perhaps always Catholic, or just pretending to be converted, and for those the Inquisition was created. But eight centuries of mixing is a very long time, and no one can determine with any degree of certainty his exact origins.

Those Moors and Spaniards, even if enemies, were sons of the Reinos de Taifa, and their vision of the world was opposite to that of the Protestant pilgrims who conquered the northeastern lands of America. The Spaniards mixed because they themselves were the product of centuries of racial mixing. Even if explicitly they felt superior 
and were cruel conquerors, implicitly they adopted an acceptance toward mixing, unlike the Protestant pilgrims who advocated the preservation of a pure origin. That ideology of purity is so extreme that even now, when the United States has also become a melting pot, some people there try desperately to trace their ancestry, sharing the same anguish, fear, and arrogance held by the pilgrims before them.

There now exists a demand for equal treatment among the socalled minorities. It is a call to be the same that may lead to a new racism because every minority at war shares with the pilgrim settlers that puritanical attitude towards identity, perhaps with a different content: a different color may be raised to a higher status, but the same racist mind is there.

Mestizaje does not create a one and only kind of being: it is not another race with the same appearances in every group and a hyphen in the words describing it. Mestizaje creates an almost infinite number of combinations. Many times it creates a white-faced person whose brother or cousin has dark skin.

It is very different to think of ourselves as mestizos than as minorities. Mestizaje is the future of all minorities and even their actual present in many cases. But a different mentality is needed to recognize this; one that does not appeal to the racist anguish of making the epic defense of our origins or our roots. In the mind of the mestizo our roots are one of the many ingredients of that eternal mystery: who are we? We are made of many affiliations and everyone has the right to recognize them. Manuel Machado did so when he wrote: "Yo soy como los hombres que a mi tierra vinieron, soy de la raza mora, vieja amiga del sol, que todo lo ganaron, y todo lo perdieron. Tengo el alma de nardo del árabe español” (Machado 1902). ${ }^{2}$ Morocco offered me the living proof that a Moorish vein could be alive in my own Mexican mestizaje.

On the cultural side this proof is even more evident. Medieval Spain cannot be studied without taking into consideration those eight centuries of Andalusí presence, and no medievalist can be considered serious if Arabic is not among the languages he reads. More than four

2 "I am like the men who came to my land. I am from the Moorish race, old friend of the sun. Men who won and lost it all. My soul is like the nard of the Arabic Spaniard". 
thousand words of the Spanish language we use today in America are of Arabic origin. For centuries, Spain was both Orient and Occident.

Traces of Arabic culture traveled to America in ways other than the language and the mestizaje mentality. We lose the perspective of those times when viewed from our modernity. It is difficult to imagine that the Arabic civilization was so advanced at that time, compared to others, that it had established a way of doing things that was followed not only by Muslims but also by Catholics and Jews. Some traces of that civilization can be seen now in objects and buildings in Mexico. The Arabs invented a particular way of creating pottery, of weaving and constructing, using the greatest technology at that time. And that technology, applied to the things used in everyday life, was used by the Spanish conquerors in America to build wooden roofs for Catholic churches, fortresses, and palaces, and to create pottery and textiles. And even the Catholic missionaries, after introducing lamb's wool to America, mixed their Spanish (actually Arabic) weaving technology with that of the Indians. For this reason even the textiles of the Indians from the mountains in Chiapas, those textiles everyone in Mexico wants to consider one hundred per cent Mexican, incorporate many technical solutions and designs in common with the Berber textiles that may be found in the Atlas Mountains of Morocco.

The Arabic civilization came to us without its religious Islamic message, and it became ours. One example can be traced in ceramics. Even a jar with its abstract design can speak loudly of the paths a civilization has taken. Mexico is proud of its glazed pottery, particularly that made in Puebla, but also in Guanajuato, a majolica pottery called Talavera de Puebla. Its name reveals that it was introduced to Mexico by ceramists from a Spanish town near Toledo named Talavera de la Reina, a town famous for its ceramics in Andalusí times. Its glazed blue motifs come from far away: Persia, Samarkanda, even China, many centuries ago. When the expulsion of the Arabs from Spain took place in the fifteenth century, many ceramists of that town migrated to Fez, where they established workshops. The converted ones and their Spanish pupils went to America. Mainly to the city of Puebla in Mexico. The Spanish town of Talavera de la Reina had its own evolution: a strong Italian Renaissance influence, among others. The result is that the Mexican pottery known as Talavera is very different from that made in Talavera de la Reina, but it is very similar to the blue pot- 
tery made in the city of Fez. The pottery created in the Mexican town of Guanajuato, with its predominant designs in green and yellow, is more similar to that found in the Moroccan port of Safi.

We can presume that many other similarities between Morocco and Mexico followed a similar pattern. We can venture to say that in a certain way both Morocco and Mexico descend in part from the Andalusí civilization. It is a common thread in the complex textile of these two countries' mestizaje. At times our two countries seem like twin brothers who finally meet each other after years of separation and recognize amazing similarities in each other. That was the frame of mind created by my discovery of Morocco. And step by step through the years that frame has become for me a deeper perspective, a space to see and understand. I will mention also a few personal experiences placed into that perspective that marked my approach to Morocco. And then, like in a circle, I will come back to the "frame question" of identity.

On our first journey to Morocco, my wife and I arrived to the small oasis town of Zagora, just beyond the Sahara. Our arrival coincided with a moment of crisis between Algeria and Morocco. There was war in the air, and a curfew was in place. We noticed that the people of the town were very excited, not because of the possible armed conflict but because it had rained the night before.

A German geologist we had met that morning invited us to climb the mountain in front of the village in order to observe the evaporation of the water. "It is something you can only see here every ten years, more or less". We asked for a military permit to climb, and then we had one of the most amazing visions. In the air we saw the water take the shape of nearly transparent clouds that flew toward us and continued their flight toward the midday sun. Surprisingly, each cloud had captured some sounds from the town, like capsules of words and whispers, of cries and laughter.

Surrounding the palm fields, we saw blankets of small fragile flowers with thin petals in vivid colors moving in the wind. They seemed to grow before our eyes. "They appear in the desert only when it rains. This is an exceptional view", explained our friend. Sadly, 
after a couple of hours the sun began to burn them. Those flowers cast me into an abyss of images which I could not easily identify at first. Suddenly, in the heart of that turmoil, I saw my father talking to me when I was a small child. He said that I should not be sad because each flower leaves behind many seeds that will open whenever the next rain comes, and many flowers will grow again. Many more each time. I was there, in the Sahara, remembering something that happened when I was three or four years old, after we had moved to a small town in Baja California, into the Sonora desert of Mexico. We arrived after a hurricane, and it had rained for the first time in more than ten years. And the same kind of flowers I saw in the Sahara had grown before my eyes as a young boy. I began to recall so many things from my earliest childhood that I did not know I had forgotten. It was as if a huge container of memories had spilled open. And so the Moroccan Sahara gave me access to my earliest memories.

In that state of mind, with my eyes full of unexpected visions, we continued traveling after the curfew was cancelled two weeks later. On the road from Agadir to Essaouira, in a place where there is little vegetation, we saw a group of small trees full of black spots that I imagined at first to be vultures. When we moved closer, our surprise grew larger than the trees when we realized that they were covered with goats calmly chewing the leaves of the branches. Amazed, I pointed this out to a Moroccan student sitting near me on the bus. Not in the least surprised, he thought I was admiring the trees and explained proudly that the Argan trees exist only in Morocco. I said that it was not the trees but the climbing goats that amazed me. I must have seemed like an excited fool to him, for he remarked calmly, "goats are always in the trees", as if explaining to a baby an elementary truth. What for me was radically magic, for him was a banality, an everyday thing not worthy of notice.

It was then that I decided that my work as a poet should have as one of its aims to discover that dimension of life that is more interesting and surprising than we imagine: goats in the trees of my life, my work, my wife, my friends, my country. I decided to make the vision of those goats a poetics and at the same time a guiding principle that would determine my way of facing life and my way of creating works of literature, of building a work. A principle of composition that I call a Poetics of Wonder. 
That same day we arrived at the walled city of EssaouiraMogador. I cannot explain now, in detail, the feeling of "ritual initiation" I had as we approached the port. I recognized there the need to slow down and become more perceptive of the original nature of the place I was visiting and to abandon my previously established ideas about a city. Mogador is so different from Fez or Marrakech. Even when one visits Mogador and walks its streets with a map as a guide, it cannot be possessed. An appearance of simplicity offered by the outlines on the map is not so simple. The Mogadorian people are very mixed and therefore extremely open to newcomers. The walls of the city are like a skin that embraces more than protects the town, creating an internal urban space, a body. These sensations produced in me the concept of Mogador as a lover to be approached with extreme care. Listening to her desires rather than imposing my own. Knowing Mogador, living in it became an erotic experience. And I began to inhabit it, symbolically, forever. And so the city also became the image of a lover. And a protagonist of my tales.

In the beginning, placing my stories in Mogador was not a very conscious choice, and I could not imagine the dimension that it would acquire in my life. After visiting Morocco, all my characters and all the stories I had decided to place elsewhere always ended up in Mogador. It became an obsession, but a useful one in the sense that the place had the ingredients that would not distract my readers with images of familiar places. In film terms, it was like showing a close-up of the characters and their drama, their fears and dreams. And then, little by little, introducing full shots, or back images of the place in the exact measure that was useful in my narrative and poetic research. It was like using abstract elements to introduce the reader into a very intense world of sensuality. And the city could become like the aroused skin of the characters desiring or in love.

I dreamed that for a sensitive reader to discover and understand my image of the place would be like a ritual initiation implicating all their senses and their imagination and not only the intellect; and not at all the literary emotion of suspense so often employed in traditional novels. I was searching for the same feeling of sensuous initiation that I felt when I saw Mogador for the first time. The same feeling that comes over me every time I visit her. Adding and composing details, 
the city became a more or less complex location not only in terms of a literary composition, but as the key to my own identity.

There was a parallel consequence of all this in my writing. As I searched for that feeling of sensuous initiation, I had to develop a way of telling stories that was closer to poetry than to traditional narrative. I was not making a choice of literary genre, but rather trying to be faithful to what I wanted to tell and how I wanted it to be understood, felt, and perceived by all the senses of the reader. I wrote what I needed without the limitations of rules of genre. I had to develop a strong aesthetical composition. My models came from other artistic fields: the art of azulejos, of geometrical tile compositions, for example, that in Morocco is highly developed and one of the best in the world.

I observed and learned the internal logic of those amazing tile boards named zelijes, which only some masters of this art, the maalems, can execute with a distinctive splendor and creativity. I transformed their internal structure into a metaphor for the structure of my books, for each one in the series of books of desire that take place in Mogador, but also for the whole series as one composition.

The transcendental sense of contemplation that inhabits those geometrical boards gave to my stories a sense of formal spirituality. I discovered in Andalusí and Arabic classical literature and philosophy, in those mystic texts linking eroticism to mysticism, mainly Ibn Arabí, Ibn Hazm, ${ }^{3}$ Attar, al-Nafzawi, Al-Ghazali, the dimension I wanted my books to have, the dimension they were already generating. Even in classical Arabic literature I found ancient generic forms closer to what I was doing, forms that the first Arabic and Arabist commentators of my books brought to my attention, for example the $a d a b$, a literary form in which an idea, a scene and a strong impression need not be separated. A genre, we can say in our terms, fusing poetry and prose, essay and narrative. I found in Mogador a technical narrative solution for a literary need that was completely new to me.

3 Among them, the more subtle, deep and sensuous is Ibn Hazm of Córdoba, author of Tawq al-hammama, written in the year 1022; translated by Emilio García Gómez as El collar de la paloma (Hazm of Córdoba 1952); and by Anthony J. Arberry as The Ring of the Dove: A Treatise on the Art and Practice of Arab Love (Hazm of Córdoba 1953). 
Many readers of my books have considered Mogador an imaginary city, and it is in fact imaginary, but only as it is reconstructed by words, like any city that we describe. And that happens as much in books of fiction as in the so equivocally called non-fiction, and it happens with any city, including the one we inhabit at the moment we create its portrait. We can be extremely faithful to the spirit of a city even while fictionalizing it. Or we can be absolutely faithful to its physical aspect. But in both cases it is always a reconstruction through literary images. Any written place is or becomes imaginary.

I am proud of seeing Mogador included in The Dictionary of Imaginary Places, by Alberto Manguel. ${ }^{4}$ As much as I am proud of seeing Moroccan critics consider my books faithful to their culture and their places. ${ }^{5}$

Several journalists in Mexico asked why I mention in the same novel (On the Lips of Water) a real place like Sonora and an imaginary one called Mogador. But in Morocco they asked me why I incorporate in the same novel a real place like Mogador-Essaouira and an imaginary one, Sonora. We easily believe that what we do not know is imagined by someone. But it is a greater mistake to believe that any written description of what we do know and of what is closer to us is a real portrait or non-fiction.

To believe blindly in the declared virtues of so-called non-fictional writing supposes a fetishism that annuls the distance between a thing and its representation. It is like worshipping the painted portrait of a god as if it were the god itself. The origin of that fetishism of the written word is in the religious culture that believes in the Bible as the ultimate truth. The difference between fiction and non-fiction is a fabrication of the culture described by Max Weber in his book The Protestant Ethics and the Spirit of Capitalism. And it is the same spirit and the same ethics that produced the modern idea of our identity as the product of what is popularly called "our true roots". The idea of revealed truth is a twin idea to the belief in one culture and race being superior to the others. Discrimination is a fact in the world. But asking

4 Guadalupe/Manguel (1999: 430-431; 2000: 378-379).

5 Aouad Lahrech (1998); also Banlabah (2004). 
for a quota of everything for each "minority" is a confirmation of those same values reducing what we are to one dimension of life.

This brings us back to the question of who we "truly" are. The answer is not as simple as some religions, nations, or racial groups would like us to believe. Many times it is a reductionist question supposing that we are something strictly reduced to our origin, religion, social class, race or other restricted affiliation. But life gives us surprises. Sometimes we are lucky enough to discover, somewhere else, new dimensions of the others and of ourselves. I believe, with Amin Maalouf, that "Identity is not given once and for all: it is built up and changes throughout a person's life time” (Maalouf 2000: 23) and that

Every individual should be able to identify, at least to some degree, both with the country he lives in and with our present day world. This involves the adoption of certain habits and types of behavior, not only by the individual himself, but also by the people around him, whether groups or individuals. Each of us should be encouraged to accept his own diversity, to see his identity as the sum of all his various affiliations, instead of as only one of them raised to the status of the most important, made into an instrument of exclusion and sometimes a weapon of war (Maalouf 2000: 159).

We are also what we are becoming, what we emphasize in our lives, and I am becoming a southern lover of Mogador, of North Africa, of its people and places. A Mexican writer becoming a bridge of sand (words are as fragile as grains of sand) between the Sonora desert and the Sahara. I claim for myself and others the right to be a citizen of all the places of my choice, the places that chance offers me to know and love. And, sometimes, to be loved. I claim the right to pay less attention to the roots and much more to the flowers.

In our modern rational and functional vertigo, we do not give Chance the place it deserves. But it is by chance that many of the most important things in our lives happen. By chance we meet the person we will live with. I met my wife in the line to register at the university. And with her, many years ago, I also had the chance to discover Morocco. I had the chance to receive from Morocco some gifts that were unique and gave sense to my work and my life: 
1. The gift of friendship and warmth from my Moroccan friends.

2. The gift of being close to a marvelous country, Morocco, and a marvelous city, Mogador.

3. The gift of the unexpected remembrance of my forgotten early childhood in the Sonora desert.

4. The gift of a Poetics of Wonder.

5. The gift of an extended erotic conception of life in which there is always a search, a path, a spiritual dimension.

6. The gift of technical narrative lessons taken from the traditional Arabic crafts and thought.

7. The gift of discovering an aesthetic dimension of life present and alive in every corner of the country.

8. The gift of a new territory: another dimension of Mexican culture, the Andalusí one. Another way of understanding Mexico and my mestizaje.

9. The gift of a different understanding of who I am. Of what I am becoming. Of what I do.

\section{Bibliography}

Aouad Lahrech, Oumama (1998): “Alberto Ruy Sánchez y Mogador: puente colgante entre las dos orillas del Atlántico". Conference read in Essaouira, Troisième Session de L'Université Conviviale de Mogador (5-8 november 1998) $<$ http://www.angelfire.com/ar2/libros/Oumamogador.html>.

Banlabah, Fatiha (2004): “Alberto Ruy Sánchez ou le Voyage de Retour”. Conference read in Casablanca, Salon du Livre (6 march 2004) <http://www.angelfire.com/ ar2/libros/ FATIHA.html>.

Guadalupe, Gianni/Manguel, Alberto (1999): The Dictionary of Imaginary Places. Newly updated and expanded edition. Toronto: Knopf.

- (2000): Breve Guía de lugares imaginarios. Madrid: Alianza Editorial.

Hazm of Córdoba, Ibn (1952): El collar de la paloma. Transl. Emilio García Gómez Madrid: Alianza.

- (1953): The Ring of the Dove: A Treatise on the Art and Practice of Arab Love. Transl. Anthony J. Arberry. London: Luzac (new edition 1994).

Maalouf, Amin (2000): In the Name of Identity. Violence and the Need to Belong. New York: Penguin.

Machado, Manuel (1902): “Adelphos”. In: Alma (reprinted 1988 Madrid: Ediciones Cátedra).

Ruy-Sánchez, Alberto (1987): Los nombres del aire. México: Joaquín Mortiz (new edition 1996 México: Alfaguara). 
- (1993): Mogador, the Names of the Air. Transl. Mark Shafer. San Francisco: City Lights.

- (1994): Cuentos de Mogador. México: CNCA.

- (1996): En los labios del agua. México: Alfaguara.

- (1999): De cómo llegó a Mogador la melancolía. Paris: Du Rocher.

- (2001a): Los jardines secretos de Mogador. México: Alfaguara.

- (2001b): “Por un Orientalismo Horizontal”. In: Artes de México 55 “Arte Mudéjar: Variaciones”, pp. 30-37.

- (2002): La huella del grito. México: Solar.

- (2005): Nueve veces el asombro. México: Alfaguara. 



\title{
Andreas Pflitsch
}

\section{To Fit or Not to Fit. Rabih Alameddine's Novels Koolaids and I, the Divine}

\author{
What the hell am I doing here? \\ I don't belong here \\ (Radiohead, Creep).
}

"In America, I fit but I do not belong. In Lebanon, I belong but I do not fit" (Alameddine 1998: 40). This is how one of many protagonists and narrators in Rabih Alameddine's first novel Koolaids. The Art of War describes his situation between two different kinds of 'home'. In the following I want to present some examples of how this author circles the topics of identity, home, homelessness, belonging and fitting.

Alameddine was born in 1959 in Jordan to a family of Lebanese Druze origin. He was raised and educated in Kuwait, in Lebanon, and in England. Today he lives as a painter and a writer in San Francisco and in Beirut. Alameddine writes in English. His first novel, the above quoted Koolaids. The Art of War, was published in 1998. It is a nonlinear, highly fragmented textual mosaic, a collage without a plot, narrated by a multitude of voices. The AIDS epidemic in America and the Civil War in Lebanon "merge into", as Publishers Weekly put it, "a graphic portrait of two cultures torn from the inside".

The tone of the novel is laconic, it is very economically written, an almost aphoristic text. "Death comes in many shapes and sizes, but it always comes" (Alameddine 1998: 1), reads its very first sentence. Irrespective of its tragic and even dark content, the novel is enormously humorous. Maybe the best characterization of Koolaids is given by the novel itself: "I wanted to write an endless book of time", we read in one of the many references to the book in the book.

It would have no beginning and no end. It would not flow in order. The tenses would make no sense. A book whose first page is almost identical to the last, and all the pages in between are jumbled with an interminable story. A book which would make both Kant and Jung proud. - I was not 
able to do it. I would have been copying the master. Borges did it before me (Alameddine 1998: 118).

It was also Borges who "told me historical truth is not what took place; it is what we think took place” (Alameddine 1998: 12). ${ }^{1}$ Accordingly, the narrator voices some strange views:

Ronnie was the greatest president in history, right up there on Mount Rushmore.

AIDS is mankind's greatest plague.

Israel only kills terrorists.

America never bombed Lebanon.

Jesus was straight. Judas and he were just friends. [...]

Menachem Begin and Yasser Arafat deserved their Nobels (Alameddine 1998: 12).

Koolaids “issues pronouncements", wrote Amy Tan in a review, "while pointing out the absurdities of any kind of truth. It contemplates the meaning of death while redefining the meaninglessness of life". "Reason", reads one of these pronouncements, "is only good to mummify reality in moments of calm or analyze its future storms, never to resolve a crisis of the moment” (Alameddine 1998: 106). And another one: "I wonder if being sane means disregarding the chaos that is life, pretending only an infinitesimal segment of it's reality" (Alameddine 1998: 184).

The parallelization of the two quite different deadly threats, the AIDS-virus and the civil war, is used as an artistic, literary device in more than one scene, ${ }^{3}$ e.g. when a protagonist is "cleaning out his phonebook [because] he had to erase out the names of a number of friends who have died" of AIDS. He tells his mother about it, and it reminds her of Lebanon at wartime: "In the eighties, I would go through my phone book every year. So many friends died, so many simply moved away, emigrated. The war took a terrible toll” (Alameddine 1998: 31). ${ }^{4}$ To give another example: The same woman writes in her diary:

1 Cf. Alameddine (1998: 59): "Rewriting history is a passion for most Lebanese”. Quoted from the sleeve of the paperback edition of Koolaids.

3 Cf. Alameddine (1998: 74: “Addressing a virus, a war, or oneself”; pp. 85, 88, "the good old days" when one did neither know AIDS nor the war; pp. 234sq., about Ronald Reagan: "Lebanon, like AIDS, was hardly ever mentioned by our president”).

4 Cf. also Alameddine (1998: 8). 
March 20th, 1976

Dear Diary,

This day is without a doubt the worst day of my life. The shelling was getting closer to our apartment (Alameddine 1998: 5).

Some ten pages later, we read:

September 5th, 1988

Dear Diary,

Today is without doubt the worst day of my life. Samir told me he has the AIDS virus (Alameddine 1998: 16). ${ }^{5}$

Alameddine's definition of Lebanon and the Lebanese turns out pronouncedly laconic:

Lebanon is a piece of land (not a piece of heaven at all - you only have to be in Beirut in the summer) but it's our land, our home (even if we are not actually living there). It's our Sweet Home and we love it. So we are called Lebanese (Alameddine 1998: 183).

Cultural diversity can, it is true, cause feelings of inner conflict, maybe even schizophrenia: "The happiest day in my life was when I got my American citizenship and was able to tear up my Lebanese passport. That was great. Then I got to hate Americans. And I really do" (Alameddine 1998: 243). The reason for this hate is surprisingly simple: "America is the birthplace of Wheel of Fortune and I will never forgive it for that” (Alameddine 1998: 243).

Identity can be a prison, a burden which to get rid of can develop into a real life task. The narrator suffers from identity. National clichés and cultural stereotypes haunt him. He becomes possessed with these questions as he rails at different nations like mad:

Something English. That's what I want. I am too tired of America and Americans. Still they are better than the French. I hate the French, probably more than I hate Americans. Such arrogant bastards. [...] But they are better than the Lebanese. The Lebanese are just arrogant. I fucking hate the Lebanese. I hate them. They are so fucked up. They think they are so great, and for what reason? Has there been a single artist of note? A scientist? An athlete? They are so proud of Gibran. Probably the most overrated writer in history.

5 Cf. Alameddine (1998: 47): “July 4th, 1967 - Dear Diary -, This is without a doubt the worst day of my life. It looks like we have to go back to Beirut. My husband can't take it here in Washington anymore”. 
Not surprisingly, our hero suffers badly from bitter self-hate:

I tried so hard to rid myself of anything Lebanese. I hate everything Lebanese. But I never could. It seeps through my entire being. The harder I tried, the more it showed up in the unlikeliest of places. But I never gave up. I do not want to be considered a Lebanese. But that is not up to me. [...]

Nothing in my life is up to me (Alameddine 1998: 243sq.).

So far, Koolaids. In the following year of 1999 Alameddine published The Perv, a collection of stories (Alameddine 1999), ${ }^{6}$ which was followed in 2002 by his second novel I, the Divine, which is subtitled A Novel in First Chapters. It is indeed a novel in 43 'first' chapters. Sarah Nour el-Din, the Lebanese-American protagonist, plans to write her memoir, her autobiography. She was named after Sarah Bernhardt, the great actress admired by her grandfather who "considered having met her in person the most important event of his life" (Alameddine 2002: 3). Sarah Bernhardt was known as 'the Divine Sarah', "the greatest woman who ever lived” (Alameddine 2002: 77).

Again and again Sarah Nour el-Din begins with the first chapter of what should become her memoir. She tries out different stylistic levels, different modes and genres of writing and even different languages: Two 'first' chapters are written in French. Some of the chapters are only a few lines long, others have two pages, ten, twenty or more. There are chapters written in the first person and others in third person. Alameddine also uses sort of 'fictionalized' para-texts, such as title-pages, mottos or dedications.

In the forty-third 'first' chapter, which is the very last one of Alameddine's book, Sarah sits in front of her TV, eats ice-cream and states: "I was having trouble writing my memoir, not being able to figure out how to attack it. I had tried different methods, but the memoir parried back expertly" (Alameddine 2002: 306). Sarah failed - and yet the sum of her failing attempts of writing her memoir is her memoir.

What seems at first sight to be nothing more than a nice idea, a "structural gimmick", as Publishers Weekly put it, turns out to be a highly effective device for writing a - post- or at least a very modern - novel, a device for circling the multilayered protagonist, for writing

6 For an interpretation of the story "The Changing Room” (Alameddine 1999: 6380), cf. Pflitsch (2005). 
a biography not along chronological lines. As Amy Tan put it: "the structure is literary genius [...] and perfect to the notion of someone reinventing and revising herself"?

Sarah, by reinventing and revising herself, thinks, like the - mainly male - protagonists in Koolaids, a lot about identity and home, belonging and fitting. "Whenever she is in Beirut", we read, "home is New York. Whenever she is in New York, home is Beirut. Home is never where she is, but where she is not" (Alameddine 2002: 99). Home, obviously, is not the place to be, but the place to long for because of not being there. Belonging, accordingly, describes a state of mind that has overcome the desire of being elsewhere, thus having overcome longing. Not being at home means at the same time uprootal; the drawback of freedom seems to be loneliness, as Sarah experiences it in New York:

She feels alone, experiences the solitude of a strange city where no one looks you straight in the eye. She does not feel part of this cool world, free for the first time. But at what price? How can she tell the difference between freedom and unburdening? Is freedom anything more than ignoring responsibilities, than denying duty? [...] In New York, she can disappear. What is the purpose of a city if not to grant the greatest of gifts, anonymity? Beirut offered no refuge from unwavering gazes [...]. But her heart remains there. To survive here, she must hack off a part of herself, chop, chop, chop (Alameddine 2002: 98sq.).

Home and homelessness are always ambivalent in the work of Alameddine. He does not provide simple solutions, but shows the unavoidable complexity of the topic:

I have been blessed with many curses in my life, not the least of which was being born half Lebanese and half American. Throughout my life, these contradictory parts battled endlessly, clashed, never coming to a satisfactory conclusion. I shuffled ad nauseam between the need to assert my individuality and the need to belong to my clan, being terrified of loneliness and terrorized of losing myself in relationships (Alameddine 2002: 229).

But Alameddine's novels and stories do not just, as it appears in this passage, deal with suffering from what Samuel Huntington calls the clash of civilizations. They show at the same time the latent advantages of not belonging, of not fitting. When asked about the meaning "belonging" and "fitting" have for his work, Alameddine answered

7 Amy Tan, quoted from the sleeve of $I$, the Divine (Alameddine 1998). 
that not belonging to society, i.e. having a certain kind of distance to it, is as crucial for his work as it is for each and every work of art. ${ }^{8}$ This leads me to the broader question of fitting and belonging or not fitting and not belonging and the impact this problem has on writing and literature.

In his Theory of the Novel, which was published in 1920, Georg Lukács wrote that the form of the novel is like no other genre the expression of a transcendental homelessness. ${ }^{9}$ Lukács, here, is echoing the genuine, archetypical romantic position of Novalis who defined philosophy as "homesickness", as the desire (or instinct) to be at home everywhere. ${ }^{10}$ And Theodor W. Adorno in his Minima Moralia formulated that it is part of ethics (or morality) not to be at home at one's self. ${ }^{11}$

Except for this general meaning belonging and not belonging has for literature and art, there is another, more concrete dimension of the topic in Alameddine's novels. In December 2004, the Institute for Advanced Studies in Berlin organized the workshop "ArabAmericas Literatures without a fixed abode". The goal of the workshop was to search for adequate intellectual categories for literature that does not fit into concepts such as 'national literature' or 'world literature'. It showed that the often so-called hybrid literature should by no means be confined to lamenting the schizophrenic situation of the exile. In fact, the opposite is true: This kind of literature distinguishes itself by taking a valuable position from the outside, something Ottmar Ette termed Außerhalbbefindlichkeit (Ette 2004: 229).

From this perspective, we see the peculiar way in which authors who are "writing outside the nation" (Seyhan 2001) deal with identity, individual as well as collective: Elias Abou-Haidar, Nada Awar Jarrar, Dominique Eddé, Zeina B. Ghandour, Hani Hammoud, Tony Hanania, Elie-Pierre Sabbag or Sélim Nassib - to name but a few Lebanese

8 Personal conversation, Berlin, Dec. 2004.

9 "[...] die Form des Romans ist, wie keine andere, ein Ausdruck der transzendentalen Obdachlosigkeit” (Lukács 1988: 32).

10 "Philosophie ist eigentlich Heimweh, der Trieb, überall zu Hause zu sein" (quoted in Lukács 1998: 32).

11 "Es gehört zur Moral, nicht bei sich selber zu Hause zu sein” (Adorno 1951: 58). 
writers of the younger generation who, living in Morocco, England, France and elsewhere, write in French or in English. ${ }^{12}$

To aptly describe the literature of authors like those mentioned we have to differentiate between various understandings of cultural identity. There is, first, a multicultural, second an intercultural, and third a transcultural identity. ${ }^{13}$ The first and the second refer to concepts of fragmented identities or, to put it in a more positive way, multiple identities, identities of "components". The multicultural describes a side-by-side situation, the intercultural indicates a dialogue. The established concept of the multicultural and of the intercultural implies that these kinds of "identity" are somewhat outside the norm. They seem to be imperfect, defective, inadequate. The norm is still the ethnically and culturally homogenous nation, while multiculturalism and intercultural relations are the exception, the results of a violation of the norm. Transcultural identity, on the other hand, understands identity as mobile, flexible, having no fixed borders. Transcultural identity is an identity on the move (Ette 2001). Transcultural and transnational literature is not about "establishing a dialogic relation between geographically distinct societies", but about "exploring the process of production of difference in a world of culturally, socially, and economically interconnected and interdependent spaces" (Gupta/Ferguson 1992: 14).

We have to overcome seeing transcultural identity as an exception. It is the rule, the normal case. The same, of course, is true for the concept of the nation, for national, international and transnational identities (Pflitsch 2003; 2004b). Each and every identity is unique by definition, it is necessarily and always a mixture. The collective, homogenous identity, be it national or cultural, is fiction. And it is a historically comparatively young construct, which had its heyday under the rule of the nation-paradigm in the 19th and 20th centuries. We have to give up these ideological concepts to see the many forms of transitions, overlaps and movements that constitute reality. The burden of proof has to be reversed. Cultures are by far more 'mobile' than

12 Cf. Pflitsch (2004a; 2003) and Neuwirth/Pflitsch (2000).

13 Ette (2001: 13): "Neben ein multikulturelles Nebeneinander und ein interkulturelles Zwischen- und Untereinander ist - und ich meine dies in einem sehr positiven Sinne - ein transkulturelles Durcheinander getreten, in dem sich die verschiedenen Kulturen wechselseitig durchdringen und verändern”. 
the established traditional concepts and their vocabulary allow us to express. To put it in a pathetical manner: We are prisoners of a highly ideological discourse.

To come back to Alameddine, it goes without saying that we have first of all to distinguish between author, narrator and protagonists. Whereas his narrators and protagonists often suffer from their position between two 'cultures,' the author shows how these 'cultures' are constructed or fabricated. It becomes clear that Alameddine is not just the product of Lebanon and America or a kind of result of a simple fusion of two cultures or of two national identities. ${ }^{14}$ The identity Alameddine is writing about is much more than the sum of its parts. And this is what is shown in his work. Herein lies the value and the merit of this kind of literature. It unmasks the simplistic ideas of identity.

\section{Bibliography}

Adorno, Theodor W. ([1951] 2001): Minima Moralia. Frankfurt/Main: Suhrkamp. Alameddine, Rabih (1998): Koolaids. The Art of War. New York: Picador.

- (1999): The Perv. New York: Picador.

- (2002): I, the Divine. A Novel in First Chapters. London: Weidenfeld \& Nicolson.

Ette, Ottmar (2001): Literatur in Bewegung. Raum und Dynamik grenzüberschreitenden Schreibens in Europa und Amerika. Weilerswist: Velbrück Wissenschaft.

- (2004): ÜberLebenswissen. Die Aufgabe der Philologie. Berlin: Kulturverlag Kadmos.

Gupta, Akhil/Ferguson, James (1992): “Beyond 'Culture': Space, identity and the politics of difference”. In: Cultural Anthropology VII, 1, pp. 6-23.

Lukács, Georg (1988): Die Theorie des Romans. Ein geschichtsphilosophischer Versuch über die Form der großen Epik. Frankfurt/Main: Luchterhand (1st ed. Berlin 1920).

Majaj, Lisa Suhair (2005): “Of Stories and Storytellers”. In: Saudi Aramco World LVI, 2, pp. 24-35.

Neuwirth, Angelika/Pflitsch, Andreas (2000): Agonie und Aufbruch. Neue libanesische Prosa. Beirut: Dergham.

14 In her survey of Arab-American Literature, Lisa Suhair Majaj raised the question, “how 'Arab' and how 'American' are ‘Arab-American' writers?” (Majaj 2005: $31)$. 
Pflitsch, Andreas (2003): "Literatur, grenzenlos. Aspekte transnationalen Schreibens”. In: Szyska, Christian/Pannewick, Friederike (eds.): Crossings and Passages in Genre and Culture. Wiesbaden: Reichert, pp. 87-120.

- (2004a): "Die libanesische Literatur”. In: Arnold, Heinz Ludwig (ed.): Kritisches Lexikon zur fremdsprachigen Gegenwartsliteratur. 63rd. ed. München: edition text + kritik.

- (2004b): “Ortspolygamie”. In: Neuwirth, Angelika/Pflitsch, Andreas/Winckler, Barbara (eds.): Arabische Literatur, postmodern. München: edition text + kritik, pp. 191-201.

- (2005): “'Peter Gabriel left Genesis in the summer of 1975.’ Rabih Alameddine über unterschiedliche Unterschiede”. In: Figurationen. Gender - literatur - kultur 1, pp. 13-22.

Seyhan, Azade (2001): Writing outside the Nation. Princeton/Oxford: Princeton University Press. 



\section{The Authors}

Akasoy, Anna, Research Assistant at the Warburg Institute of the University of London. E-mail: <Anna.Akasoy@sas.ac.uk>.

Recent publications: Philosophie und Mystik in der späten Almohadenzeit. Die Sizilianischen Fragen des Ibn Sabin (2006); The Arabic Version of the Nicomachean Ethics (2005, co-editor); Muḥammad ibn 'Abdallāh al-Bazyar, Das Falken- und Hundebuch des Kalifen al-Mutawakkil. Ein arabischer Traktat aus dem 9. Jahrhundert. Edited, translated and with an introduction by Anna Akasoy and Stefan Georges (2005); Ibn Sabin, Die Sizilianischen Fragen. Arabic-German. Translated and with an introduction by Anna Akasoy (2005); Arabische Romantik im Exil. Das poetische Werk des Fauzi al-Ma'lüf (2002).

Ette, Ottmar, Chair of Romance Literature at the University of Potsdam. E-mail: <ette@rz.uni-potsdam.de>.

Recent publications: ZwischenWeltenSchreiben. Literaturen ohne festen Wohnsitz (2005); ÜberLebenswissen. Die Aufgabe der Philologie (2004); Weltbewußtsein. Alexander von Humboldt und das Projekt einer anderen Moderne (2002); Literatur in Bewegung. Raum und Dynamik grenzüberschreitenden Schreibens in Europa und Amerika (2001; Literature on the Move (2003).

Fayad, Luis, writer and poet. He studied Sociology at Universidad Nacional in Bogotá, lived in Barcelona, Paris, Stockholm, today he lives in Berlin. E-mail: <fayad.luis@berlin.de>.

Recent publications: La caída de los puntos cardinales (novel, 2000); Los Parientes de Ester y Compañeros de viaje (novel, 1991); Un Espejo y Otros Relatos (short-stories, 1995); La Carta del Futuro y el Regreso de los Ecos (novel, 1993). 
Handal, Nathalie, poet, writer, playwright, director and producer. Member of Nibras Theatre Collective and Associate Artist and Development Executive for the production company The Kazbah Project. Lecturer at the Department of English and Comparative Literature at Columbia University, New York. She lives in Boston. E-mail: <natalyahandal@aol.com>.

Recent publications: Arab-American and Arab Anglophone Literature (forthcoming 2006); The lives of Rain (poetry, 2005); Spell (poetry with music by Will Solimon, CD, 2005); The NeverField (poetry, 2005); The Poetry of Arab Women (2000, editor).

Ingenschay, Dieter, Chair of Romance Literature at Humboldt University Berlin. E-mail: <dieter.ingenschay@rz.hu-berlin.de>.

Recent publications: El pasado siglo XX: una retrospectiva de la literatura latinoamericana. Homenaje a Hans-Otto Dill (2003, editor); After-Images of the City (2003, co-editor); Lateinamerikanische Literatur des 20. Jahrhunderts (2001, co-author); Die andere Stadt. Großstadtbilder in der Perspektive des peripheren Blicks (2000, co-editor).

Khoury, Elias, writer and scholar, 1976-1979 publisher, together with Maḥmūd Darwīsh, of the newspaper Shu'ūn filastinniyya (Palestinian Affairs); 1979-1991 editor for literature at the daily paper Al-Safï; 1993-1998 director of the Beirut theatre Masrah Bayrūt; since 1992 publisher and editor-in-chief of culture and literary supplement to Al-Nahār (Beirut).

Recent publications: Mamlakat al-ghurabā' (novel, Kingdom of Strangers 1993; German tr. Königreich der Fremdlinge 1998); Majmā' al-asrār (novel, Box of Secrets 1994; German tr. Der geheimnisvolle Brief, 2000); Bāb al-Shams (novel, The Gate of the Sun, German tr. Das Tor zur Sonne 2004, French tr. La porte du soleil, 2002); Yãlō (novel, 2002; French tr. Yalo, 2004).

Majaj, Lisa Suhair, writer, poet and scholar. She lives in Nicosia, Cyprus. E-mail: <lmajaj@cytanet.com.cy>.

Recent publications: What She Said (poetry, 2005); These Words (poetry, 2004); Intersections. Gender, Nation, and Community in Arab Women's Novels (2002, co-editor); Etel Adnan: Critical Es- 
says on the Arab-American Writer and Artist (2002, co-editor); Going Global: The Transnational Reception of Third World Women Writers (2000, co-editor).

Murguía, Verónica, writer and illustrator, teacher at the school of the Sociedad General de Escritores de México, writes the column "Las Rayas de la Cebra” in La Jornada (Mexico City). E-mail: $<$ dhvm55@yahoo.com>.

Recent publications: Lo que sí y lo que no. La otra escalera (children’s book, 2006); El ángel de Nicolás (short-stories, 2003); El fuego verde (novel, 1999); Auliya (novel, 1997).

Mussa, Alberto, writer, teacher of pre-Islamic poetry at Federal University of Rio de Janeiro, translated the pre-Islamic anthology Al-Muallaqat (Os Poemas Suspensos, unpublished) into Portuguese. E-mail: <betomussa@globo.com>.

Recent publications: O enigma de Qaf (2004); O trono da rainha Jinga (1999); Elegbara (1997).

Pannewick, Friederike, Assistant Professor of Arabic Studies at University of Oslo, Co-Director of the research network "Travelling Traditions. Comparative Perspectives in Middle Eastern Literatures" at the Working Group "Europe in the Middle East - the Middle East in Europe" (Institute for Advanced Studies at Berlin). E-mail: <friederike. pannewick@ikos.uio.no>.

Recent publications: Martyrdom in Literature. Visions of Death and Meaningful Suffering in Europe and the Middle East from Antiquity to Modernity (2004, editor); Das Wagnis Tradition. Arabische Wege der Theatralität (2000); Kulturelle Selbstbehauptung der Palästinenser. Survey der modernen palästinensischen Dichtung (2001, co-author).

Pflitsch, Andreas, Assistant at the Seminar for Semitic and Arabic Studies at Freie Universität Berlin. E-mail: <a.pflitsch@gmx.de>. Recent publications: Arabische Literaturen Postmodern (2004, coeditor); "Die libanesische Literatur", in Heinz Ludwig Arnold (ed.), Kritisches Lexikon fremdsprachiger Gegenwartsliteratur (2004). 
Romano Sued, Susana, writer and poet, Chair of Literary Aesthetics and Criticism at University of Córdoba. E-mail: <romanossr@ ciudad.com.ar>.

Recent publications: Ensayar la poesía, aproximaciones al lenguaje poético de autores contemporáneos (2004); Travesías. Estética, poética, traducción (2003); Umbrales y catástrofes: Literatura argentina de los '90 (2003); Mal del siglo (poetry, 2000); Los amantes (poetry, 2000).

Ruy-Sánchez, Alberto, writer and poet, since 1988 editor of the Arts magazine Artes de México (Mexico City). E-mail: <ars@mx. inter. net>.

Recent publications: Nueve veces el asombro (novel, 2005); La huella del grito (novel, 2002); Los jardines secretos de Mogador (novel, 2001); Los nombres del aire (novel, 1987; Mogador. The Names of the Air, 1993).

Spiller, Roland, Chair of Romance Literature at the University of Frankfurt am Main. E-mail: <R.Spiller@em.uni-frankfurt.de>. Recent publications: Kultbücher (2004, co-editor); Memoria, duelo y narración : Chile después de Pinochet: literatura, cine, sociedad (2004, editor); La poética de la mirada (2001, co-editor); Tahar Ben Jelloun: Schreiben zwischen den Kulturen (2000). 